Wendy Martin Rios

\title{
Construção de uma vacina de DNA bivalente para tuberculose expressando a proteína gD do HSV-1 e os epítopos da Hsp65 micobacteriana
}

DissertaÇão DE MESTRAdO

Dissertação de Mestrado apresentada à Faculdade de Medicina de Ribeirão Preto da Universidade de São Paulo para obtenção do Título de Mestre em Ciências, área de concentração: Imunologia Básica e Aplicada.

Orientador: Prof. Dr. Celio Lopes Silva

Ribeirão Preto 
AUTORIZO A REPRODUÇÃO E DIVULGAÇÃO TOTAL OU PARCIAL DESTE TRABALHO, POR QUALQUER MEIO CONVENCIONAL OU ELETRÔNICO, PARA FINS DE ESTUDO E PESQUISA, DESDE QUE CITADA A FONTE.

\section{FICHA CATALOGRÁFICA}

Preparada pela Biblioteca Central do Campus Administrativo de Ribeirão Preto-USP

Rios, Wendy Martin.

Construção de uma vacina de DNA bivalente para tuberculose expressando a proteína gD do HSV-1 e os epítopos da Hsp65 Micobacteriana - Ribeirão Preto, 2009.

185 p.: il. ; $28 \mathrm{~cm}$

Dissertação (Mestrado - Programa de Pós-graduação em Imunologia Básica e Aplicada) - Faculdade de Medicina de Ribeirão Preto/ Universidade de São Paulo.

Orientador: Prof. Dr. Celio Lopes Silva.

1. Vacina de DNA; 2. Epitopos da Hsp65; 3. Glicoproteína D; 4. Tuberculose 


\section{Dedicatória}

Dedico a minha mãe Maria das Graças Martin, ao meu marido Fernando José Gisoldi e ao meu irmão André Martin Rios, que me ensinaram o verdadeiro sentido do Amor...

"É preciso permitir que alguém nos ajude, nos apóie, nos dê forças para continuar. Se aceitamos este amor com pureza e humildade, vamos entender que o Amor não é dar ou receber, é participar."

(Paulo Coelho)

$E$ a todas as pessoas que um dia possam se beneficiar com os resultados obtidos neste trabalho. 


\section{Agradecimentos}

Ao meu orientador professor Dr. Celio Lopes Silva pela oportunidade, orientação e confiança, ingredientes essenciais a minha formação pessoal e acadêmica;

Aos professores Dr. Luis Carlos de Souza Ferreira e Dra . Ana Paula Ulian de Araújo pela orientação e pelos ensinamentos durante a realização deste trabalho;

Ao Dr. Carlos Rodrigo Zárate-Bladés pela orientação, paciência e dedicação;

Aos professores Dr. Ademilson Panunto Castelo e $\operatorname{Dr}^{\mathrm{a}}$. Ana Paula Ulian de Araújo, membros da banca, pela disponibilidade e sugestões;

Às Prof ${ }^{\mathrm{a}}$. Dr ${ }^{\mathrm{a}}$. Arlete A. M. Coelho-Castelo e Dr ${ }^{\mathrm{a}}$. Vânia Luiza Deperon Bonato por abrirem as portas dos seus laboratórios para a realização de parte do meu trabalho e pelo apoio científico;

Ao Prof. Dr. Vanderlei Rodrigues e toda sua equipe pela disponibilização de seu laboratório para realização de experimentos;

À todos os meus Grandes Amigos do Laboratório de Vacinas Gênicas, Aninha, Carlos Rodrigo, Giovanna, Iza, Liliana, Patrícia, Rodrigo, Rogério e Sheila, por toda ajuda, aprendizado e amizade. Juntos pudemos compartilhar momentos únicos e inesquecíveis. Em especial quero agradecer a Aninha, Iza e Patrícia, amigas maravilhosas, com quem sempre pude contar e aprender, agradeço ainda pelos conselhos e pelos momentos de intensa ajuda e amizade.

Às minhas Grandes Amigas Juliana e Marininha pela amizade, confiança e por toda ajuda;

À todos os Queridos Amigos do Laboratório da $\operatorname{Dr}^{\mathrm{a}}$. Vânia e $\operatorname{Dr}^{\mathrm{a}}$. Arlete, por toda colaboração e amizade: Ana Flávia, Cássia, Denise, Lívia, Luís Henrique, Marina, Paola, Pryscilla, Rubens, Alan, Ana Paula Trombone, Carolina, Everton, Isabela, José Eduardo, Júlio, Luciana, Ricardo e Thiago, sem esquecer dos que já saíram do laboratório e dos que estão chegando com muita disposição em ajudar. Quero agradecer em especial a Ana Flávia e a Pryscilla pela intensa disposição em ajudar, a Marina e Denise por todos os ensinamentos, pela ajuda em todos os momentos, desde a prova do mestrado e aos meus companheiros de disciplina, Alan, Isabela e Thiago pela convivência e cumplicidade!

Aos amigos do Núcleo de Pesquisa em Tuberculose, especialmente ao Rogério e Vanessa pela disponibilidade em ajudar sempre que necessário; fluxo;

Ao amigo Wálter Miguel Turato pela colaboração nos experimentos de citometria de 
À Débora Fernanda Vieira, aluna da Profa. Ana Paula Ulian de Araújo, que construiu os vetores de expressão em procariotos;

A todos os amigos e docentes do Programa de Pós-Graduação em Imunologia Básica e Aplicada pelo aprendizado, auxílio e amizade;

À secretária Ana Cristine, por todo apoio, auxílio e carinho;

À FAPESP, FAEPA e CNPq pelo auxílio financeiro;

Aos meus amigos Thacia e Flávio pela convivência, amizade, apoio e confiança e às minhas eternas amigas, Samantha e Thaís pelos momentos lindos que sempre vivenciamos;

Aos meus tios Dolores e Pepe pelo amor e todo auxílio;

Ao meu irmão André pela amizade, amor, ajuda e companheirismo;

Aos familiares do meu marido, Idalina, Toninho, Fernanda, Didio, James, Elis, Letícia, Vinícius, Vô Walide e Vó Cida que sempre estiveram por perto como minha família;

A você Fernando por todo carinho, dedicação, ajuda, companheirismo, compreensão e amor, as palavras não são suficientes para expressar minha gratidão por tudo que você sempre faz por mim!

A minha MÃE, a quem eu devo minha vida e formação, com quem aprendi a lutar, a nunca desistir dos sonhos e a ser feliz pelo que sou e pelo que tenho. Quero te agradecer por tudo e em especial pelo seu amor, dedicação e luta para que eu pudesse chegar até aqui, sem você nenhum sonho poderia se tornar realidade! 
"Habito o movimento e a minha pátria é todo o continente de que não sei o fim. Irei tão longe quanto for a sede e a urgência da mudança" Ruy Duarte de Carvalho (poeta angolano) 


\section{RESUMO}

A tuberculose (TB) é uma doença infecciosa causada pelo Mycobacterium tuberculosis, que necessita de uma vacina mais efetiva, pois a única vacina licenciada apresenta eficácia variando entre 0 a $80 \%$. Entre as estratégias em desenvolvimento destaca-se a vacina DNAhsp65, que consiste de um plasmídeo carregando o gene hsp65 de Mycobacterium leprae, que demonstra eficácia na profilaxia da TB. Como as HSPs são proteínas altamente conservadas e podem desencadear respostas auto-imunes, seria interessante o desenvolvimento de uma vacina baseada na utilização apenas dos epítopos da proteína Hsp65 reconhecidos por células T. Estudos com vacinas de DNA baseadas na fusão de peptídeos à glicoproteína $\mathrm{D}(\mathrm{gD})$ do Herpes Vírus Tipo-1 têm mostrado maior ativação de linfócitos T e B peptídeos-específicos. Dessa forma, o presente trabalho teve como objetivo a construção e avaliação da imunogenicidade de vacinas de DNA constituídas pelo gene da proteína $\mathrm{gD}$ e a seqüência gênica que codifica os cinco epítopos da Hsp65. Para a obtenção da sequiência codificadora dos epitopos, denominada Vac1, foi realizada uma síntese gênica e em seguida, essa seqüência foi fusionada ao gene que codifica a $\mathrm{gD}$ em dois sítios presentes em seu interior, no sítio da enzima ApaI e entre os sítios das enzimas $P v u I I$ e ApaI, com a retirada de uma porção central da gD. Além dessas construções, também foi realizada a construção da Vac2 pela ligação de fragmentos Vac1 que em seguida foi fusionada ao gene da gD no sítio de ApaI. Essas construções, gDVac1AA, gDVac1PA e gDVac2 foram clonadas no vetor pVAX1 e avaliadas quanto a expressão das proteínas. Após a caracterização, camundongos foram imunizados com quatro doses das vacinas e a imunogenicidade avaliada após trinta dias da última dose. Os ensaios ex vivo foram realizados com o soro para dosagem de anticorpos e com as células do baço, que foram estimuladas com as proteínas Hsp65, Vac1 e Vac2. Como resultado, obtivemos duas construções vacinais, pVAXgDVac1PA e pVAXgDVac2, eficientes em induzir anticorpos do subtipo $\operatorname{IgG} 2 \mathrm{a}$ específicos a proteína e aos epitopos da Hsp65 e as três vacinas, pVAXgDVac1AA, pVAXgDVac1PA e pVAXgDVac2, foram capazes de induzir proliferação de linfócitos T e produção de IFN- $\gamma$ após estímulo ex vivo. As vacinas foram, portanto, eficazes em desencadear um padrão de resposta Th1 importante no combate ao bacilo $M$. tuberculosis. 


\section{ABSTRACT \\ CONSTRUCTION OF A BIVALENT DNA VACCINE ENCODING MYCOBACTERIUM HSP65 EPITOPES AND HSV-1 GD PROTEIN AGAINST TUBERCULOSIS}

Tuberculosis (TB) is an infectious disease, caused by the infection with Mycobacterium tuberculosis and needs a vaccine more effective, for the only current permitted vaccine shows its effectiveness varying of 0-80\%. DNAhsp65 vaccine is among the strategy in development, it consists of a plasmid loading the Mycobacterium leprae hsp65 gene and has been efficient in the prophylaxy of TB. As the HSPs are conserved and they can induce autoimmune disease, a vaccine based only in the epitopes of the Hsp65 protein recognized for $\mathrm{T}$ cells could be more interesting. Studies with DNA vaccines based on the fusion of peptides to Herpes Type Virus-1 D glycoprotein $(\mathrm{gD})$ have improved the activation of peptide-specific $\mathrm{T}$ and $\mathrm{B}$ cells. In this context, the aim of this study was the construction of DNA vaccines encoding gD protein plus Mycobacterium leprae Hsp65 protein epitopes and the evaluation of its immunogenicity. The gene sequence encoding the five Hsp65 epitopes, called Vac1, was obtained by synthetic gene and, after that, this sequence was fusioned in two sites inside gene that enconding the $\mathrm{gD}$, in the ApaI enzyme site and between the PvuII and ApaI enzyme sites with the withdrawal of a $\mathrm{gD}$ central portion. In addition, Vac2 was contructed through the linking of Vac1 fragments followed by its insertion in the ApaI site inside gD gene. These constructions, gDVac1AA, gDVac1PA and gDVac2 were cloned in pVAX1 vector and they were evaluated to protein expression. After the characterization, mice were immunized with four doses of vaccine and the immunogenicity was evaluated after thirty days from the last immunization. The ex vivo assays were carried by quantification of antibodies in the serum and the splenocytes were stimulated with the Hsp65, Vac1 and Vac2 proteins. As result, two vaccine constructions, pVAXgDVac1PA and pVAXgDVac2 were efficient in the induction of $\operatorname{IgG} 2$ a subtype antibodies specific to Hsp65 protein and its respective epitopes. All the three vaccines pVAXgDVac1AA, pVAXgDVac1PA and pVAXgDVac2 were capable to induce $\mathrm{T}$ cell proliferation and IFN- $\gamma$ production after stimulation. Therefore, the vaccines were efficient to induce a Th1 profile which is important in the combat to Mycobacterium tuberculosis bacillus. 


\section{LISTA DE FIGURAS}

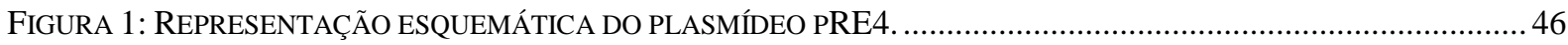

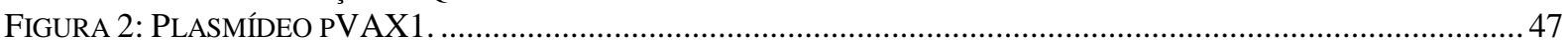

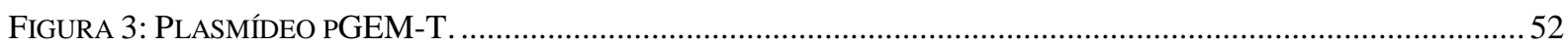

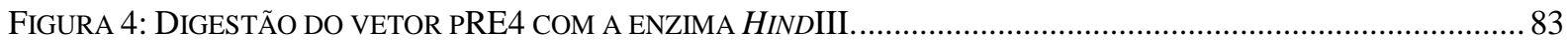

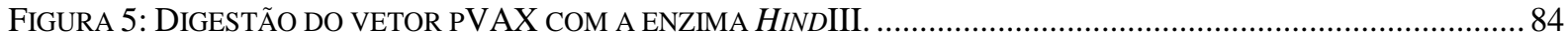

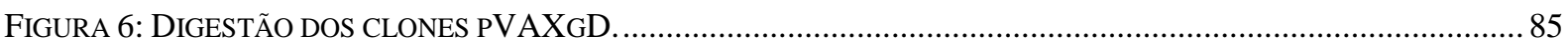

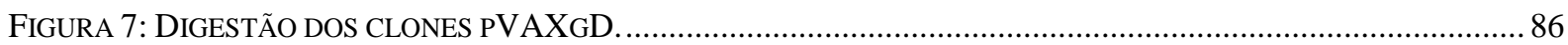

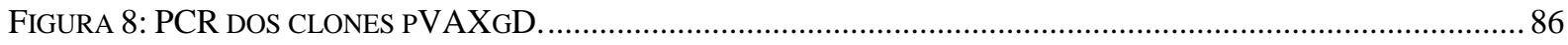

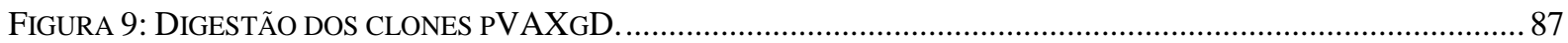

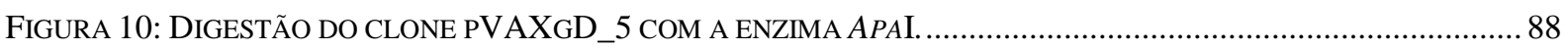

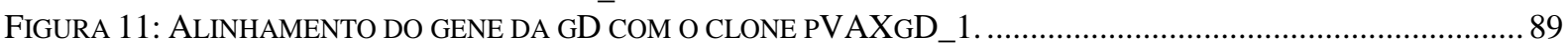

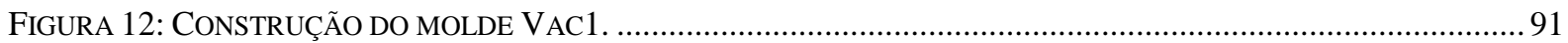

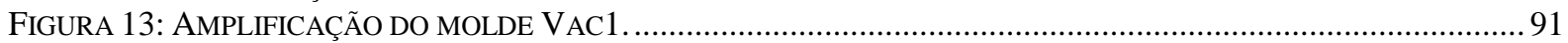

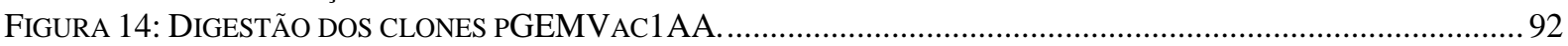

FIGURA 15:ALINHAMENTO DA VAC1AA COM O CLONE PGEMVAC1AA_3 _.................................................93

FIGURA 16: DIGESTÃO DO CLONE PGEMVAC1AA_3 COM A ENZIMA APAI.................................................93

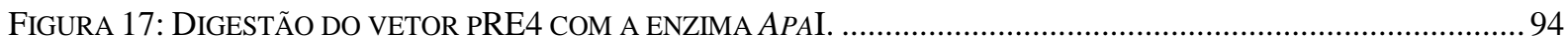

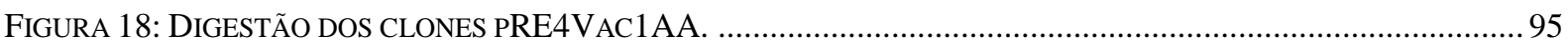

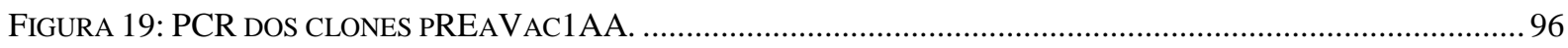

FIGURA 20: CLIVAGEM DO CLONE PRE4VAC1AA_2 COM A ENZIMA HINDIII...............................................96

FIGURA 21: PCR DE COLÔNIA DA LIGAÇÃO ENTRE PVAX E GDVAC1AA. .......................................................97

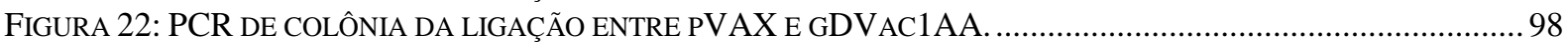

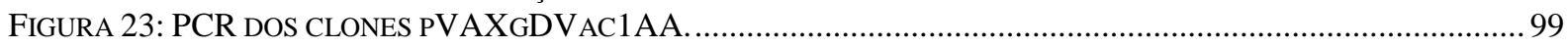

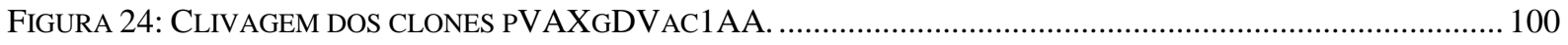

FIGURA 25: ALINHAMENTO DO FRAGMENTO GDVAC1AA COM O CLONE PVAXGDVAC1AA_7 ....................... 101

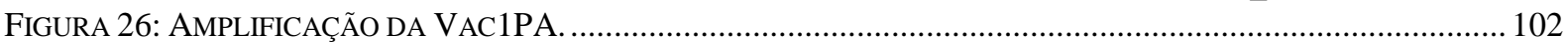

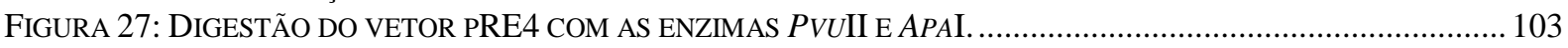

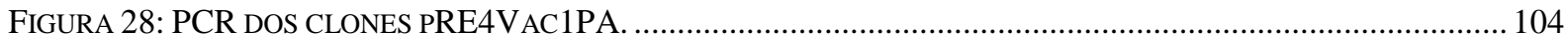

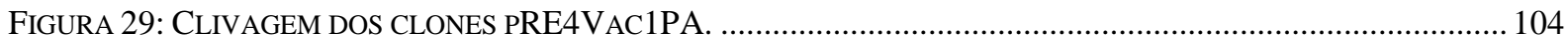

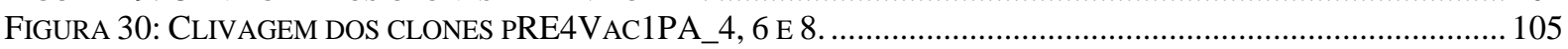

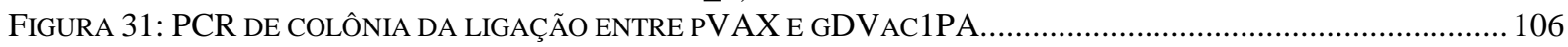

FIGURA 32: PCR DOS GRUPOS 7, 8, 9 E 10 DE COLÔNIAS DA LIGAÇÃO ENTRE PVAX E GDVAC1PA..................... 107

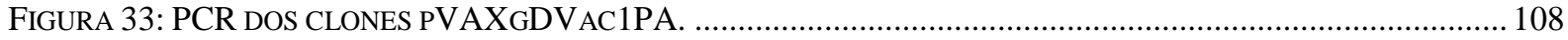

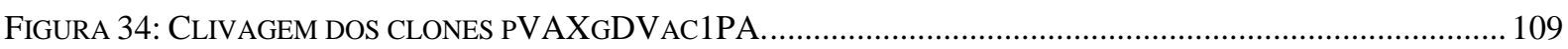

FIGURA 35: ALINHAMENTO DO FRAGMENTO GDVAC1PA COM O CLONE PVAXGDVAC1PA_11 ...................... 110

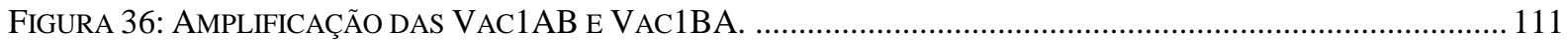

FIGURA 37: LIGAÇÃO ENTRE OS FRAGMENTOS VAC1AB E VAC1BA. ............................................................ 111

FIGURA 38: PCR DE COLÔNIA DA LIGAÇÃO ENTRE PRE4 E VAC2 . ................................................................ 112

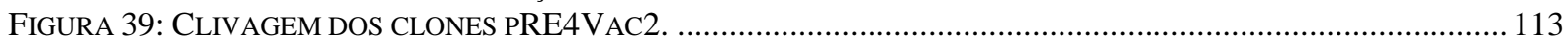

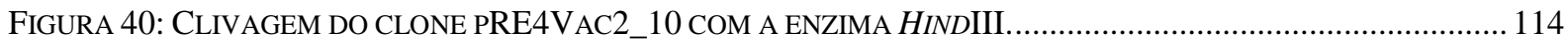

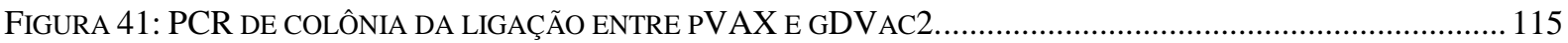

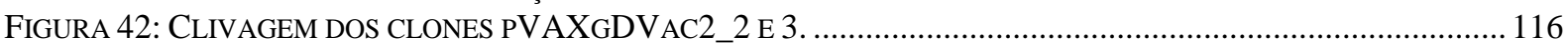

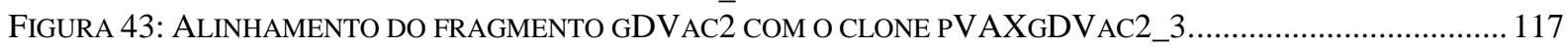

FIGURA 44: CLIVAGEM DAS CONSTRUÇÕES VACINAIS............................................................................ 118

FIGURA 45: EXPRESSÃO, TESTE DE SOLUBILIDADE E PURIFICAÇÃO DA PROTEÍNA RECOMBINANTE VAC1...........119

FIGURA 46: EXPRESSÃO, TESTE DE SOLUBILIDADE E PURIFICAÇÃO DA PROTEÍNA RECOMBINANTE VAC2 ........... 121

FIGURA 47: CARACTERIZAÇÃO DOS ANTICORPOS ANTI-VAC1 E ANTI-VAC2 ................................................. 123

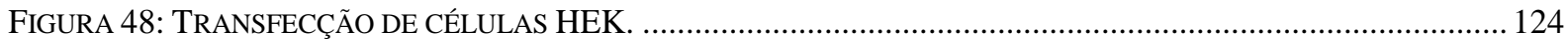

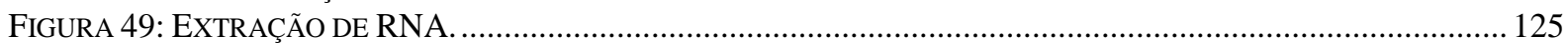

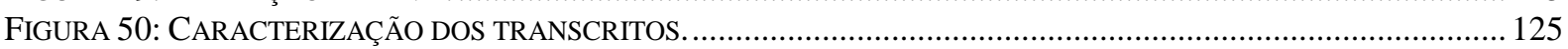

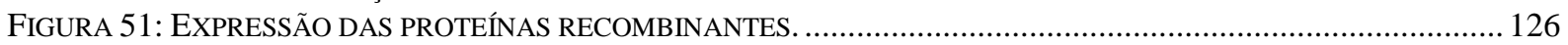

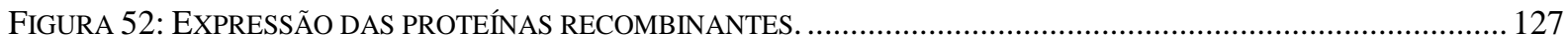

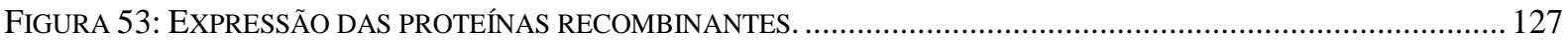

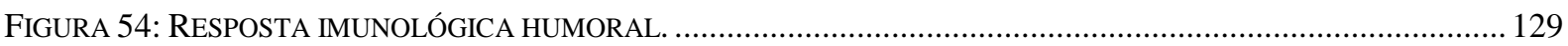

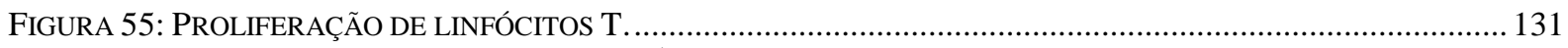

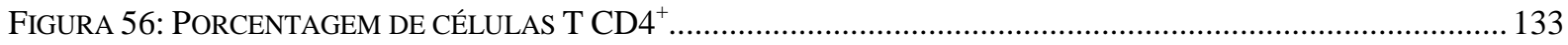

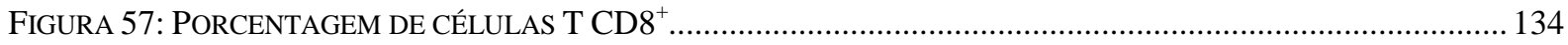

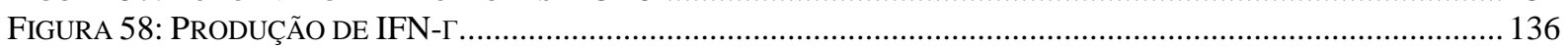




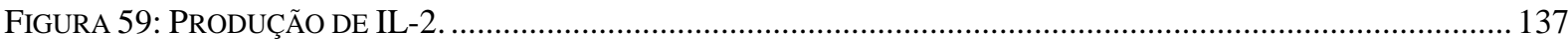

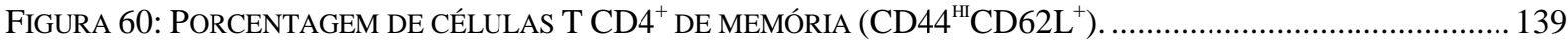

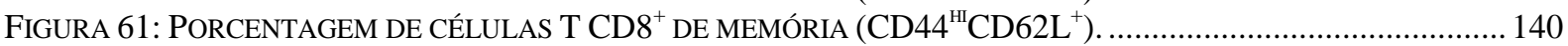




\section{ABREVIATURAS}

Aa: aminoácido

Ad: Adenovírus

Ag85: Antígeno 85

AIDS: Síndrome da Imunodeficiência Adquirida

AP-1: Proteína Adaptadora 1

APC: Célula Apresentadora de Antígeno

BAP: Fosfatase Alcalina Bacteriana

BCG: Bacilo de Calmette-Guérin

BGH: Hormônio de Crescimento Bovino

BSA: Albumina Sérica Bovina

BTLA: Atenuador de Linfócito T e B

CD: Grupo de Diferenciação

cDNA: DNA Complementar

CfaB: Subunidade Estrutural da Fimbria CFA/1

CFP: Proteínas de Filtrado de Cultura

CMV: Citomegalovírus

ConA: Concanavalina A

CpG: Dinucleotídeos Citosina-Guanina

CR: Receptor de Complemento

CRD: Domínio Rico em Cisteína

CTL: Célula T citotóxica

Da: Daltons

DAB: 3,3'-Diaminobenzidina

DC: Células Dendríticas

DC-SIGN: Dendritic Cell-Specific ICAM-3 Grabbing Non-integrin

DEPC: Dietilpirocarboneto

DNA: Ácido Desoxiribonucléico

dNTPs: Desoxinucleotídeos Fosfatados

DO: Densidade Óptica

EDTA: Ácido Diaminoetileno tetra-acético

ELISA: Ensaio Immunoenzimático de Adsorção

ESAT-6: $6 k D a$ Early Secreted Antigenic Target 
ETEC: Escherichia coli enterotoxigênica

FDA: Food and Drugs Administration

FITC: Isotiocianato de Fluoresceína

FSC: Forward Scartter

GAPDH: Gliceraldeído 3 Fosfato Desidrogenase

gD: Glicoproteína D

GFP: Proteína Fluorescente Verde

HEK: Células de Embrião de Rim Humano

HIV: Vírus da Imunodeficiência Humana

HLA: Antígeno Leucocitário Humano

HPV: Papilomavírus Humano

HSP: Proteína de Choque Térmico

HSP65: Proteína de Choque Térmico de $65 \mathrm{kDa}$

HSP60: Proteína de Choque Térmico de 60kDa

HSV-1: Vírus do Herpes Tipo 1

HVEM: Mediador de Entrada do Vírus da Herpes

IFN- $\boldsymbol{\gamma}$ : Interferon-gama

Ig: Imunoglobulina

IL: Interleucina

IPTG: Isopropil- $\beta$-D-Tiogalactopiranosídeo

LAL: Lisado de amebócito de Limulus $s p$

LAM: Liporabinomanana

LB: Luria Bertania

LPS: Lipopolissacarídeo

manLAM: Lipoarabinomanana Manosilada

MDR: Multi-Droga Resistente

MHC: Complexo Principal de Histocompatibilidade

MR: Receptor de Manose

Mtb: Mycobacterium tuberculosis

MVA: Vírus da vaccinia Ankara modificado

NK: Células Naturalmente Citotóxicas

NOS: Óxido Nítrico Sintase

NPT: Núcleo de Pesquisas em Tuberculose

OMS: Organização Mundial da Saúde 
OPD: Ortofenilenodiamino

pb: Pares de Base

PBS: Salina Tamponada com Fosfato

PCR: Reação em Cadeia da Polimerase

PE: Ficoeritrina

PECy: Ficoeritrina Cy-Chrome

PMSF: Fluoreto de Fenilmetilsulfonila

PPD: Derivado Protéico Purificado

PRR: Receptor de Reconhecimento Padrão

RNA: Ácido Ribonucléico

RSV: Vírus Rousarcoma

SBF: Soro Bovino Fetal

SDS: Duodecil Sulfato de Sódio

SDS-PAGE: Eletroforese em Gel de Poliacrilamida em Condições Dissociantes

SSC: Side Scartter

TAE: Tris Acetato EDTA

TB: Tuberculose

TCR: Receptor da Célula T

TGF: Fator de Crescimento e Transformação

Th1: Célula T auxiliar tipo 1

Th2: Célula T auxiliar tipo 2

Th17: Célula T auxiliar tipo 17

TLR: Receptor do Tipo Toll

TM: Temperatura de Melting

TNF: Fator de Necrose Tumoral

Treg: Célula T reguladora

XDR: Extensivamente Resistente a Drogas 


\section{SUMÁRIO}

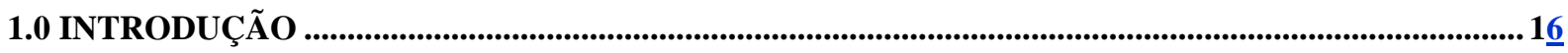

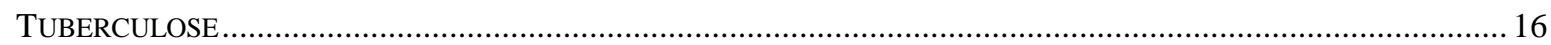

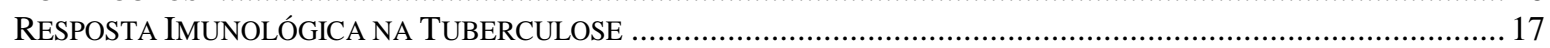

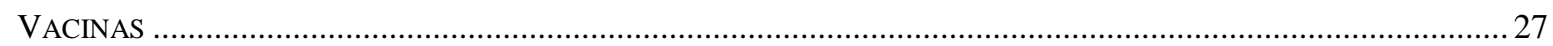

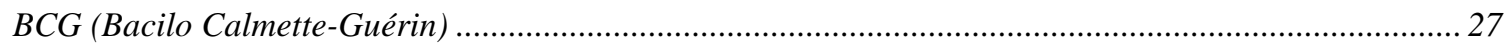

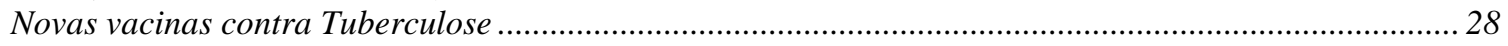

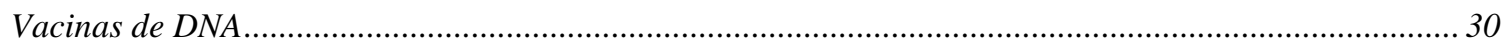

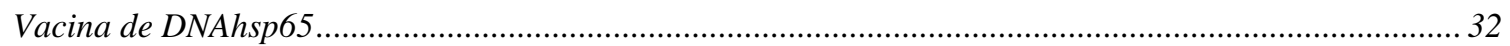

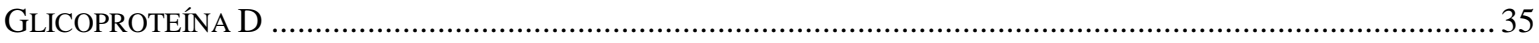

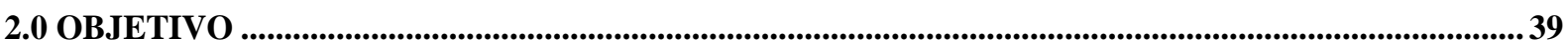

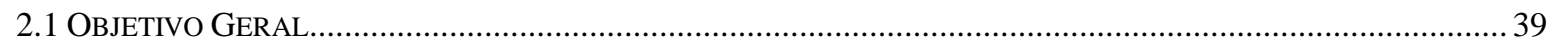

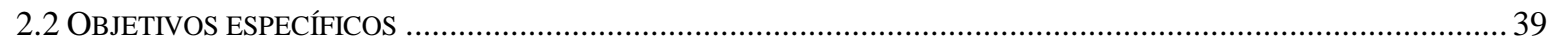

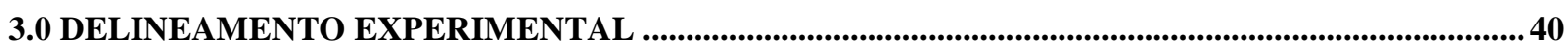

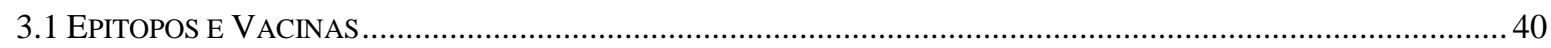

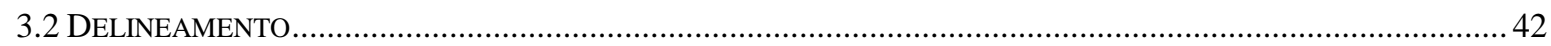

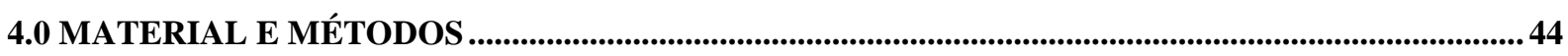

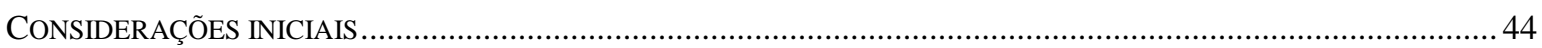

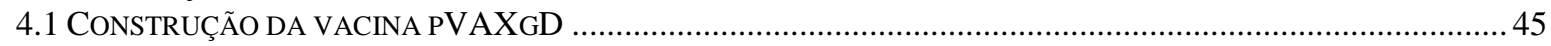

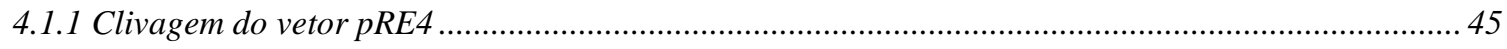

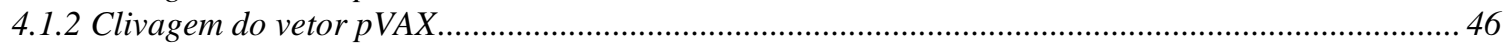

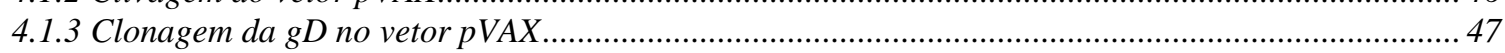

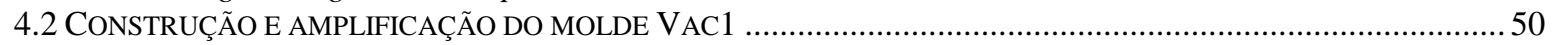

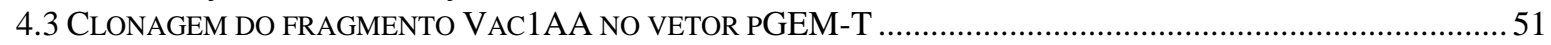

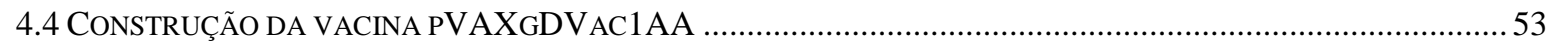

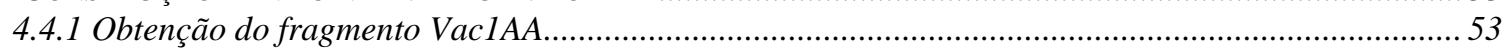

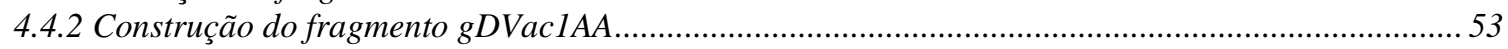

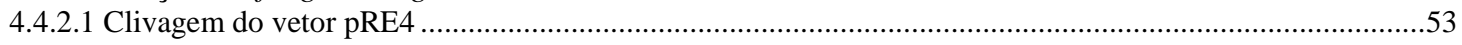

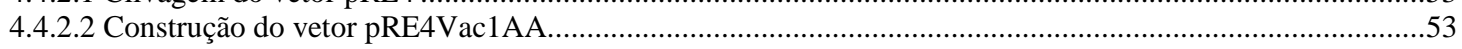

4.4.2.3 Obtenção do fragmento gDVac1AA …………………………………………………………………54

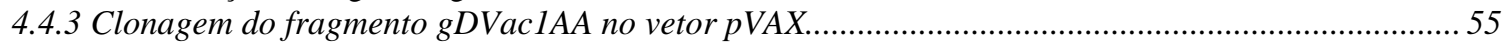

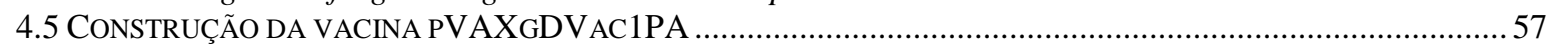

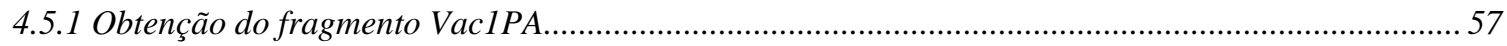

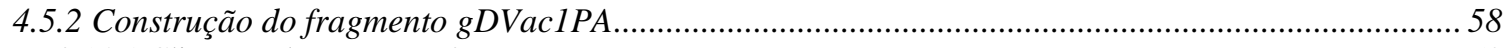

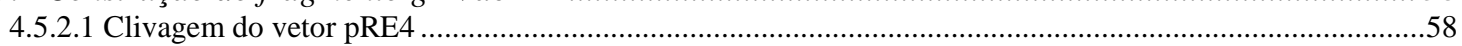

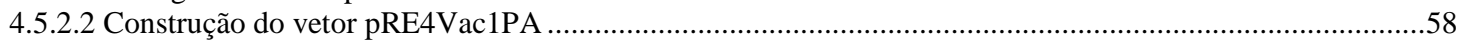

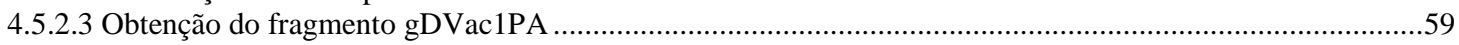

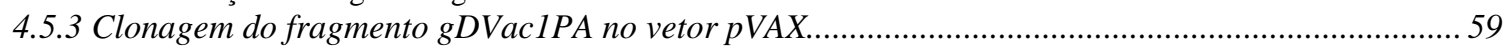

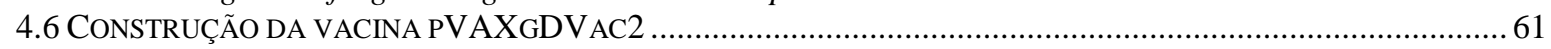

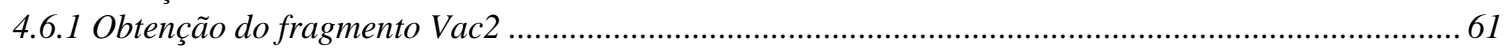

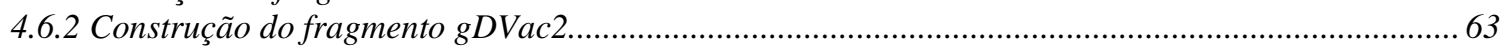

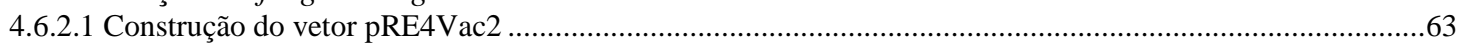

4.6.2.2 Obtenção do fragmento gDVac2 ………………………………………………………………….......

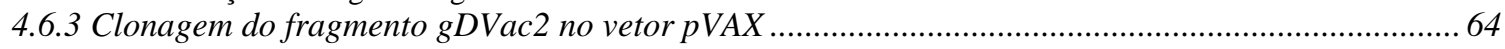

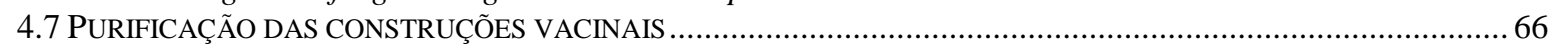

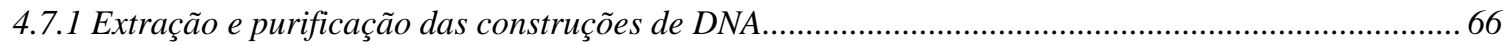

4.7.2 Quantificação, avaliação da integridade e pureza dos plasmídeos purificados.................................. 67

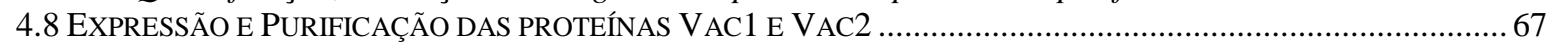

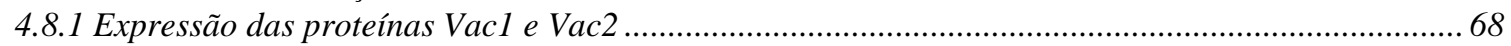

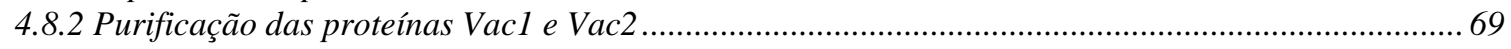

4.9 PRODUÇ̃̃O DE ANTICORPOS POLICLONAIS CONTRA AS PROTEÍNAS VAC1 E VAC2 ….................................... 71

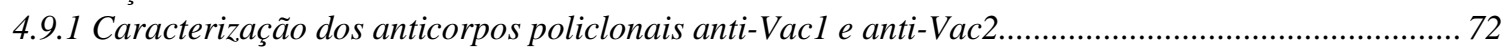

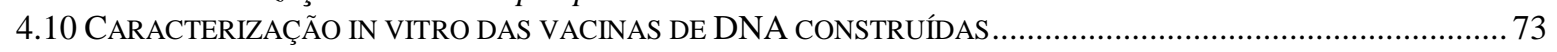

4.10.1 Transfecção de células in vitro com as vacinas construídas ........................................................... 73

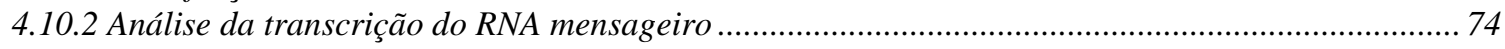

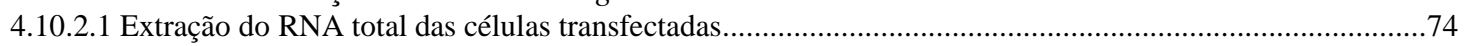


4.10.2.2 Transcrição reversa e avaliação da presença dos transcritos...................................................................75

4.10.3 Análise da expressão das proteínas recombinantes ( "Western blot") )........................................... 76

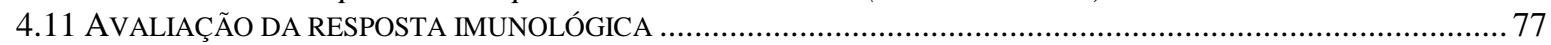

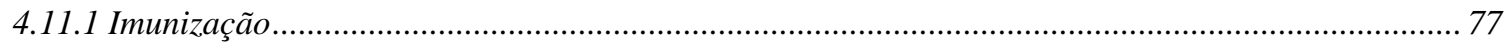

4.11.2 Avaliação da resposta imunológica humoral............................................................................ 78

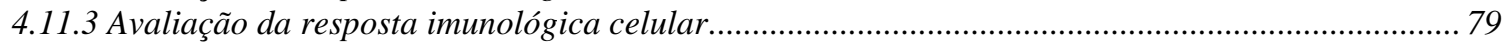

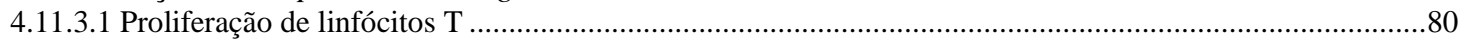

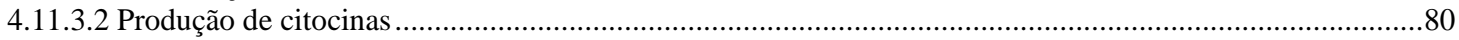

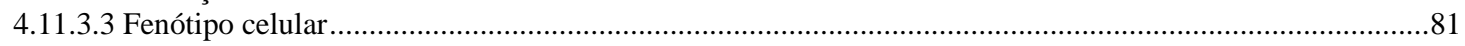

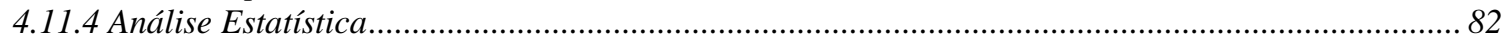

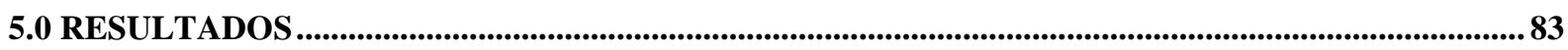

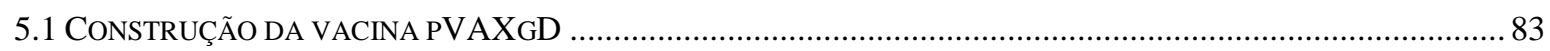

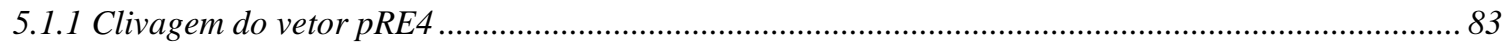

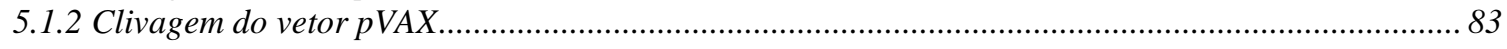

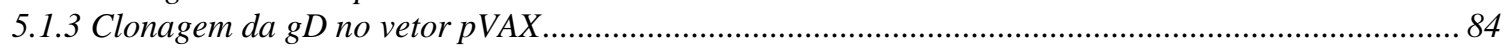

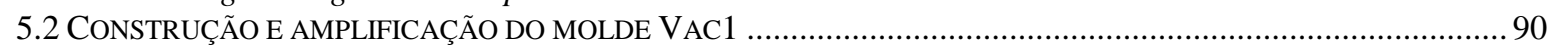

5.3 CLONAGEM DO FRAGMENTO VAC1AA NO VETOR PGEM-T ......................................................... 92

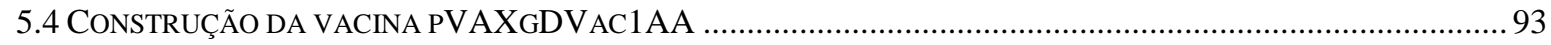

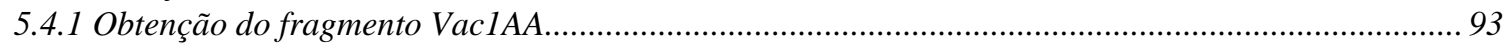

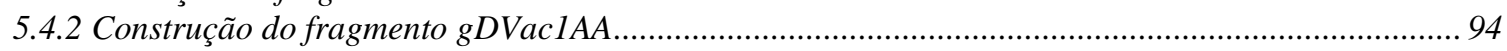

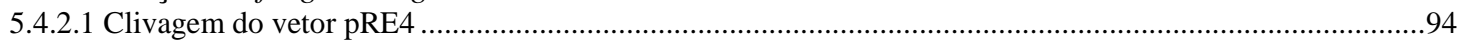

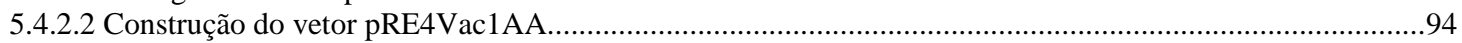

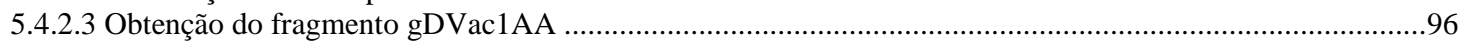

5.4 .3 Clonagem do fragmento gDVac1AA no vetor $p$ VAX................................................................ 97

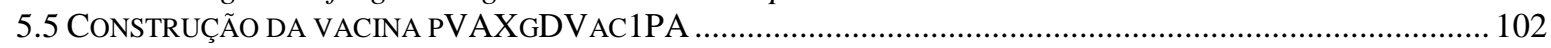

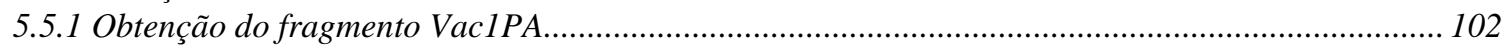

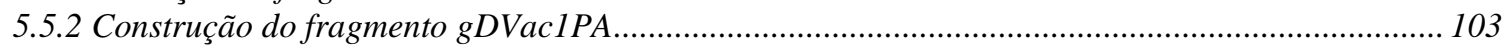

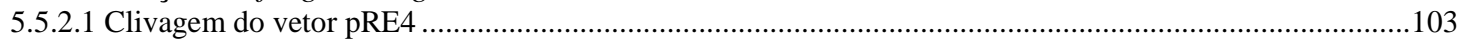

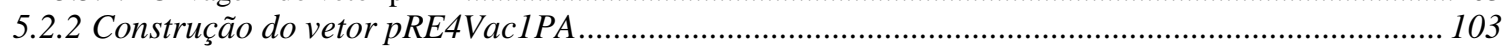

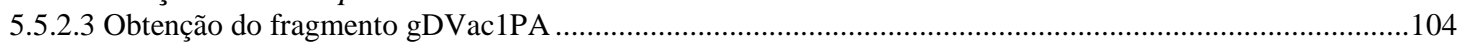

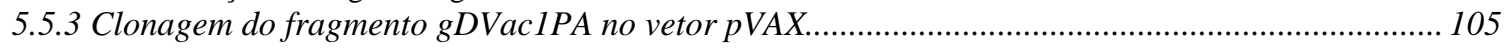

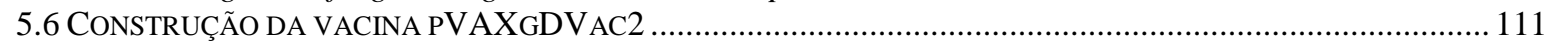

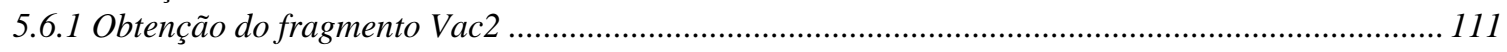

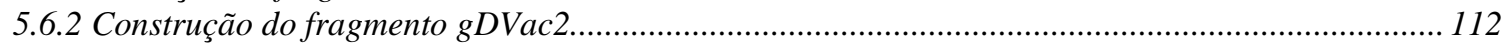

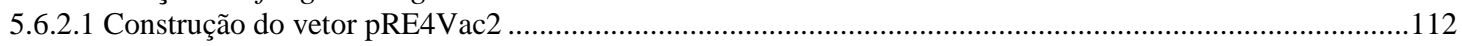

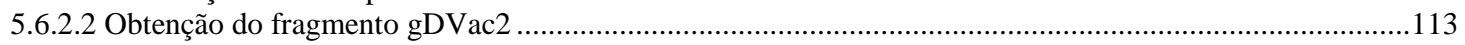

5.6.3 Clonagem do fragmento gDVac2 no vetor $p$ VAX .................................................................. 114

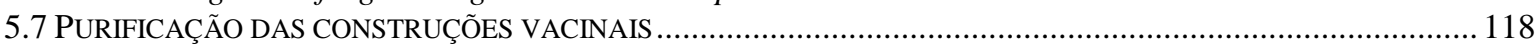

5.7.1 Avaliação da integridade dos plasmídeos purificados.................................................................... 118

5.8 EXPRESSÃO E PURIFICAÇÃO DAS PROTEÍNAS VAC1 E VAC2 …............................................................ 118

5.9 PRODUÇÃO E CARACTERIZAÇÃO DOS ANTICORPOS POLICLONAIS ANTI-VAC1 E ANTI-VAC2 ..................... 122

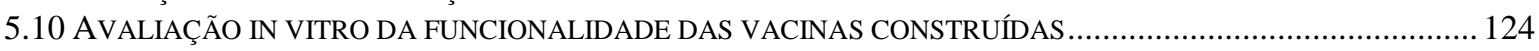

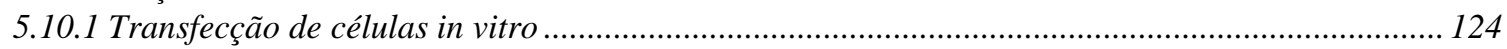

5.10.2 Análise da transcrição do RNA mensageiro ............................................................................... 124

5.10.3 Análise da expressão das proteínas recombinantes................................................................ 126

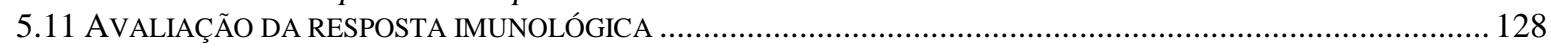

5.11.1 Avaliação da resposta imunológica humoral................................................................................... 128

5.11.2 Avaliação da resposta imunológica celular................................................................................. 130

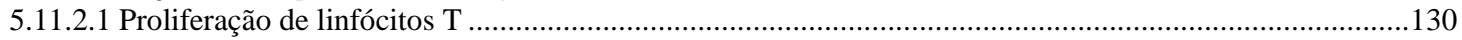

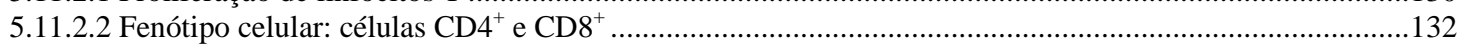

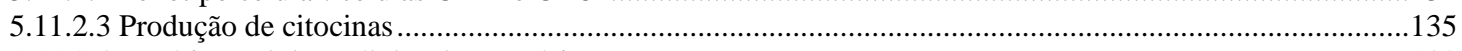

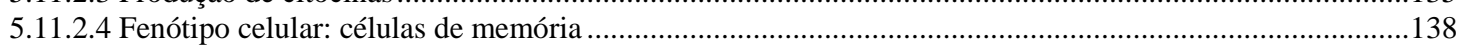

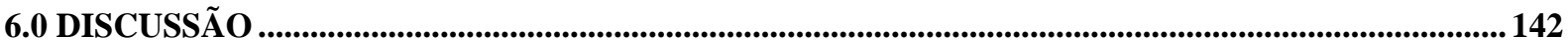

7.0 CONCLUS

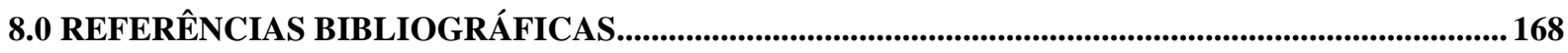

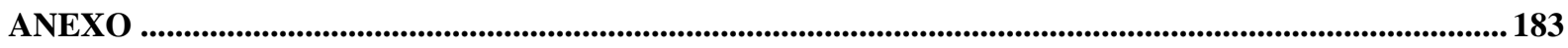

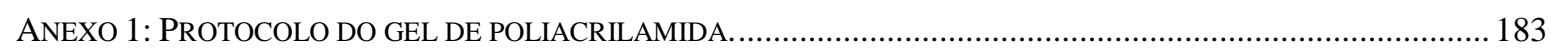

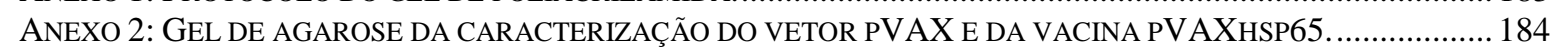


ANEXO 3: "WESTERN BLOT" UTILIZADO-SE O ANTICORPO ANTI-VAC1 PARA CONFIRMAR A EXPRESSÃO DA PROTEÍNA HSP65 CODIFICADA PELA VACINA PVAXHSP65. 184 ANEXO 4: ANÁLISE ELETROFORÉTICA DA HSP65 EXPRESSA E PURIFICADA. 


\subsection{INTRODUÇÃO}

\section{Tuberculose}

A tuberculose (TB) é uma doença infecciosa causada pelo bacilo Mycobacterium tuberculosis. Esta doença foi uma das primeiras que teve seu agente etiológico descoberto e uma vacina desenvolvida (Calmette, 1929; Koch, 1982), no entanto, permanece como a segunda maior causa de morte por doenças infecciosas no mundo (Kochi, 2001). Dados epidemiológicos indicam que um terço da população mundial (aproximadamente 2 bilhões de pessoas) está infectada com o bacilo da TB (Kochi, 2001), cerca de 8 a 10 milhões de novos casos ocorrem todo ano e aproximadamente 1,7 milhões de pessoas morreram de TB em 2006 (Tuberculosis, 2007).

Essa doença sempre esteve presente em países em desenvolvimento, no entanto, esta última década foi marcada por uma reemergência global da TB, devido principalmente a coinfecção com o vírus da imunodeficiência humana (HIV), a ineficiência dos sistemas de saúde, as condições de desnutrição e pobreza em determinadas regiões. Embora a maioria dos casos de TB possa ser tratada com as drogas disponíveis na atualidade, a duração da terapia é um dos principais obstáculos e, consequentemente, o abandono do tratamento contribui para o aparecimento de casos de M. tuberculosis multi-drogas resistentes (MDR) (Espinal, 2003) e, mais recentemente, das cepas extensivamente resistentes (XDR) (Raviglione, 2006; Tuberculosis, 2007) o que contribui ainda mais para a reemergência da doença.

Embora a TB possa ocorrer em outras partes do corpo humano (ossos, rins, pleura, intestino, cérebro, etc), a tuberculose pulmonar é a forma mais comum da doença (Flynn e Chan, 2001). Grande parte da população mundial já entrou em contato com M. tuberculosis, no entanto, de 5 a $10 \%$ desenvolvem a TB ativa. Os outros 90 a $95 \%$ desenvolvem uma infecção latente, com formação do granuloma e com 5\% de chance de reativação da doença (Smith, 1994) devido a um quadro de imunossupressão, causado por diversos fatores, como a 
infecção pelo HIV, desnutrição, tratamento prolongado com corticóides e abuso de álcool e drogas (Flynn e Chan, 2005; Rook, Dheda et al., 2005).

A infecção com M. tuberculosis depende de vários fatores associados à bactéria, como o número e a virulência dos bacilos inalados e as próprias variações genéticas desse microorganismo, depende também de fatores associados ao hospedeiro como, variações genéticas da resposta imunológica (Berrington e Hawn, 2007) e a condição imunológica do indivíduo exposto (Dannenberg, 1993). Um grande desafio é entender melhor a resposta imunológica do hospedeiro contra o bacilo M. tuberculosis, entender o que leva a resistência ou susceptibilidade a esse patógeno, porque alguns indivíduos apresentam a TB disseminada e a maioria a TB pulmonar (Berrington e Hawn, 2007) e porque a única vacina licenciada apresenta grande variação na sua eficácia (Fine, 2001).

\section{$\underline{\text { Resposta Imunológica na Tuberculose }}$}

M. tuberculosis é uma bactéria aeróbica considerada Gram positiva por possuir uma camada espessa de peptideoglicanos ao redor da membrana plasmática formando a parede celular. No entanto, essa estrutura apresenta características particulares quando comparada a parede das outras bactérias Gram positivas. Formada por $60 \%$ de lipídios a parede desse bacilo impede a passagem de uma grande quantidade de substâncias que o torna resistente a detergentes, antibióticos, corantes e ácidos. Apesar dessa bactéria ser considerada Gram positiva, sua identificação é feita principalmente pela técnica de Ziehl-Neelsen, na qual o bacilo é corado com fucsina e não descora com solução ácido-álcool, caracterizando-o como uma bactéria álcool ácido resistente. Esse bacilo é, ainda, um patógeno intracelular capaz de estabelecer uma infecção por toda a vida do hospedeiro e a resposta imunológica desencadeada contra ele é bastante complexa envolvendo muitos componentes do sistema imunológico (Patrick R. Murray, 1997). 
A infecção com M. tuberculosis é estabelecida quando partículas de aerossol contendo bacilos viáveis são inaladas e alcançam os alvéolos pulmonares do indivíduo (Loundon, 1967). No pulmão, esse patógeno interage primeiramente com os macrófagos alveolares que fagocitam-no através principalmente dos receptores de manose (MR, Mannose Receptor) e do complemento 3 (CR3, Complement Receptor 3) (Schlesinger, 1993; Kang, Azad et al., 2005). No entanto, vários outros receptores, CR1, CR4, CD14 (CD, Cluster Diferenciation), receptor Scavenger A e receptor da proteína surfactante A também podem reconhecer e ligar ao bacilo M. tuberculosis (Ernst, 1998).

Após o contato do bacilo M. tuberculosis com os macrófagos alveolares, células dendríticas (DC, Dendritic Cell) e macrófagos derivados de monócitos também são envolvidos no processo de fagocitose (Henderson, Watkins et al., 1997; Thurnher, Ramoner et al., 1997). Apesar da expressão de CR3 e MR nas DCs, essas células utilizam principalmente uma lectina, DC-SIGN (SIGN, Specific Intercellular Adhesion MoleculeGrabbing Nonintegrin) que se liga a manLAM (Mannosylated Lipoarabinomannan), lipomanana, arabinomanana e o antígeno de 19kDa (kDa, kilodalton) na superfície do bacilo para internalizá-lo (Bodnar, Serbina et al., 2001; Tailleux, Schwartz et al., 2003). O DCSIGN foi primeiramente descrito em células dendríticas, entretanto, estudos recentes demonstram a expressão induzida desse receptor em macrófagos alveolares sendo encontrado nos macrófagos do lavado broncoalveolar de pacientes com TB (Tailleux, Pham-Thi et al., 2005).

Outros receptores envolvidos no reconhecimento de patógenos são os TLRs (TLR, Toll Like Receptor) que constituem uma família de proteínas transmembrânicas conhecidos como receptores de reconhecimento padrão (PRR, Pattern Recognition Receptor) (Aderem e Ulevitch, 2000). A interação entre $M$. tuberculosis e os TLRs é um evento inicial e estudos in vitro indicam que esse patógeno é reconhecido por vários TLRs, incluindo TLR2, TLR1, 
TLR6, TLR9 e possivelmente TLR4 (Quesniaux, Fremond et al., 2004). Alguns estudos indicam o papel central do TLR2 no reconhecimento desse bacilo que expressa um grande repertório de ligantes para essa molécula, lipoproteínas, lipídeos e LAM (Liporabinomanana) (Brightbill, Libraty et al., 1999; Underhill, Ozinsky et al., 1999; Thoma-Uszynski, Stenger et al., 2001). No entanto, estudos recentes demonstram que TLR9 coopera com TLR2 no reconhecimento do bacilo $M$. tuberculosis por macrófagos e células dendríticas (Bafica, Scanga et al., 2005; Berrington e Hawn, 2007).

Os macrófagos são descritos como essenciais na indução da resposta imunológica contra a TB pelo fato de serem as células que contêm os bacilos e também por exercerem funções microbicidas como a liberação de enzimas lisossomais durante a fusão do fagossoma ao lisossoma e a geração de intermediários reativos do oxigênio (ROIs) e do nitrogênio (RNIs) que são tóxicos para o bacilo. Além disso, os macrófagos atuam como células apresentadoras de antígenos (APCs, Antigens Presenting Cells) e podem ativar a imunidade adaptativa (Flynn, 2004).

Outra conseqüência importante da interação do bacilo $M$. tuberculosis com macrófagos e DCs é a rápida indução da produção de quimiocinas e citocinas pro e antiinflamatórias, como TNF- $\alpha$, IL-12, CXCL2 e CXCL10 responsáveis pelo recrutamento e ativação das células (Ferrero, Biswas et al., 2003). Essas citocinas e quimiocinas recrutam células $\mathrm{T}$, neutrófilos e células natural killers (NK) para o local da infecção coordenando a resposta inflamatória e adaptativa contra M. tuberculosis (Berrington e Hawn, 2007).

As células NK são recrutadas para o pulmão durante os estágios iniciais da infecção com M. tuberculosis, são fontes primárias de IFN- $\gamma$ e podem causar lise dos macrófagos infectados (Vankayalapati, Garg et al., 2005). O IFN- $\gamma$ é uma citocina essencial para a ativação eficiente dos macrófagos por induzir NOS2 (NOS, Nitric Oxide Synthase) responsável pela formação dos RNIs (Bhatt e Salgame, 2007), além disso, essa molécula 
regula a migração de neutrófilos para o pulmão (Feng, Kaviratne et al., 2006). Outra célula importante nessa fase da infecção são as células NKT (apresentam receptor de célula T-TCR, $T$ Cell Receptor e marcador de células NK) que reconhecem antígenos não protéicos de $M$. tuberculosis associados as moléculas CD1d expressas em APCs e restringem o crescimento do bacilo de maneira dependente de granulosima (Beckman, Porcelli et al., 1994; Gansert, Kiessler et al., 2003).

Além do recrutamento de células NK e NKT estudos realizados em camundongos indicam que as células $\mathrm{T} \gamma \delta$ precedem as células convencionais $\mathrm{T} \mathrm{CD}^{+}$e $\mathrm{T} \mathrm{CD}^{+}$e são importantes em modular a resposta imunológica efetora contra a TB. Uma vez ativadas essas células secretam IFN- $\gamma$ e TNF- $\alpha$ que reforçam a capacidade bactericida dos macrófagos. Essas células se concentram na superfície epitelial e estão em maior número em pessoas infectadas com M. tuberculosis ou vacinadas com BCG (Bacilo Calmette-Guérin) (Li, Rossman et al., 1996; Hoft, Brown et al., 1998). Após o contato com M. tuberculosis as células T $\gamma \delta$ também secretam IL-2, apresentam atividade citolítica (Munk, Gatrill et al., 1990) além de secretar IL17 em resposta a IL-23 secretada por células dendríticas (Lockhart, Green et al., 2006).

O TNF- $\alpha$ secretado pelos macrófagos infectados e outros tipos celulares é uma molécula bastante importante no controle da TB. Essa citocina, além de atuar em sinergismo com IFN- $\gamma$ induzindo a morte de M. tuberculosis via RNIs (Chan, Xing et al., 1992) também pode promover a morte por apoptose dos macrófagos infectados (Keane, Balcewicz-Sablinska et al., 1997). Nesse caso pode favorecer a apresentação cruzada de antígenos micobacterianos as células $\mathrm{T} \mathrm{CD}^{+}$por células APCs que fagocitam os corpos apoptóticos (Winau, Weber et al., 2006). A importância do TNF- $\alpha$ na defesa do hospedeiro é demonstrada em estudos no qual o tratamento com anti-TNF- $\alpha$ torna camundongos mais susceptíveis a infecção com BCG (Kindler, Sappino et al., 1989), o hospedeiro falha no controle da replicação bacteriana (Flynn, Goldstein et al., 1995) bem como na formação do granuloma (Roach, Bean et al., 
2002). Além disso, tem-se observado que pacientes tratados com anti-TNF- $\alpha$ apresentam reativação da TB (Gardam, Keystone et al., 2003).

Apesar das várias funções efetoras da resposta imunológica os bacilos são altamente adaptados ao homem e ao infectá-lo são capazes de escapar dos mecanismos iniciais de defesa desencadeados pelo hospedeiro. Algumas dessas estratégias de escape estão relacionadas ao metabolismo oxidativo dos macrófagos. A interação preferencial via receptores como o CR3, por exemplo, impede o "burst" oxidativo, diminuindo a produção de ROIs e evitando a ação tóxica dos mesmos sob M. tuberculosis (Wright e Silverstein, 1983). Além disso, enzimas como a catalase e superóxido dismutase produzidas pelas micobactérias são capazes de degradar espécies reativas do oxigênio (Cole, Brosch et al., 1998). O bacilo da TB também é capaz de sobreviver no interior de macrófagos evitando a fusão do fagossomo com o lissosomo (Armstrong e Hart, 1975). Estudos demonstram que a fagocitose do bacilo $M$. tuberculosis via interação LAM-receptor de manose em macrófagos humanos impede a formação do fagolisossomo (Kang, Azad et al., 2005).

Além disso, os bacilos submetidos às condições variadas de estresse no interior dos macrófagos, como a própria entrada na célula do hospedeiro, liberam altas concentrações de proteínas de choque térmico, como a Hsp65, as quais podem induzir a liberação de TNF- $\alpha$ e de TGF- $\beta$, aumentar a transcrição das citocinas IL-1, IL-10 e TNF- $\alpha$ e diminuir a transcrição da enzima óxido nítrico sintase (NOS) e, conseqüentemente, diminuir a síntese de RNIs (Lima, Bonato et al., 2001). Os bacilos também podem inibir a apoptose dos macrófagos infectados reduzindo a atividade do TNF- $\alpha$ como é visto em macrófagos infectados com $M$. tuberculosis H37Ra virulento (Balcewicz-Sablinska, Keane et al., 1998)

Dessa forma o estabelecimento da imunidade inata contra os bacilos não é suficiente para eliminá-los, mas é muito importante no direcionamento da imunidade específica que potencializa os mecanismos efetores da imunidade inata. 
A ativação da imunidade adaptativa é dependente de células dendríticas que após a interação com M. tuberculosis em um processo dependente de TLRs aumentam a expressão de moléculas co-estimulatórias (CD40, CD86 e CD80), moléculas de adesão e do receptor de quimiocina CCR7, passando de um fenótipo imaturo que é eficiente na fagocitose para um fenótipo maduro eficiente na apresentação de antígenos (Buettner, Meinken et al., 2005). Essas células migram para os linfonodos drenantes e ativam células T que são responsáveis pela imunidade adaptativa (Abbas, 2005). As células T adquirem inicialmente um padrão Th1 que é crítico na proteção contra a TB.

Esse padrão observado é ativado devido a três citocinas, a IL-12 que foi a primeira citocina descrita com essa função, a IL-23 (compartilha a cadeia p40 com a IL-12) e mais recentemente a IL-27. A IL-12 induz e mantém o padrão Th1 e é uma citocina importante na estimulação da produção de IFN- $\gamma$ (Bhatt e Salgame, 2007). Estudos em camundongos deficientes de IL-12 demonstram ineficiência em conter a infecção com M. tuberculosis e a reposição com essa citocina reduz a carga bacilar e atrasa a patologia (Castro, Silva et al., 1995; Cooper, Magram et al., 1997).

A IL-27 é secretada antes da IL-12, está envolvida na iniciação do fenótipo Th1 e exibe propriedades pró e antiinflamatórias (Villarino, Huang et al., 2004). Estudos em camundongos deficientes de um componente do receptor da IL-27 demonstram diminuição na carga bacilar e aumento no infiltrado de células T $\mathrm{CD}^{+}{ }^{+}$nos pulmões (Pearl, Khader et al., 2004). Outro grupo demonstrou que na falta desse mesmo receptor há aumento na IL-12p40, TNF- $\alpha$ e IFN- $\gamma$, além da diminuição na carga bacilar (Bhatt e Salgame, 2007). No entanto, apesar do restrito crescimento da micobactéria os animais sucumbem à infecção devido a grave imunopatologia (Pearl, Khader et al., 2004; Bhatt e Salgame, 2007). Dessa forma, a IL27 é mais crítica na sua ação antiinflamatória do que na indução do padrão Th1 (Villarino, Hibbert et al., 2003). 
Já a IL-23 é capaz de induzir células Th1 na ausência da IL-12, mas a resposta Th1 e a proteção contra o M. tuberculosis não são perdidas na ausência dessa citocina (Khader, Pearl et al., 2005). Apesar do envolvimento da IL-23 no desenvolvimeno das células Th1, essa citocina é principalmente descrita como indutora do padrão Th17, um fenótipo recentemente descrito para as células T.

Trabalhos mais recentes vêm demonstrando a presença de células Th17 na infecção com M. tuberculosis (Khader, Pearl et al., 2005; Lockhart, Green et al., 2006). A citocina IL23 indutora desse padrão é produzida por células dendríticas após exposição ao bacilo $M$. tuberculosis e induz a diferenciação de células Th17 (Khader, Pearl et al., 2005). Estudos vêm demonstrando que a resposta de memória Th1 vista no pulmão de camundongos vacinados e infectados com M. tuberculosis é dependente de IL-17 e IL-23 (Khader, Bell et al., 2007). Além disso, o papel dessas citocinas parece ser dispensável na resposta protetora primária, mas importante em estágios mais tardios da inflamação, pois na ausência de IL-23 há um aumento na inflamação e diminuição da fibrose (Khader, Pearl et al., 2005). Dessa forma, os níveis de IL-12 e IL-23 produzidos por células infectadas com M. tuberculosis parecem ser cruciais no balanço entre Th1 e Th17 que serão importantes na regulação da inflamação (Khader e Cooper, 2008).

Apesar do padrão Th17 ser desenvolvido na TB as células Th1 são as mais importantes no controle dessa doença. Isso é observado pelo fato do bacilo M. tuberculosis ser um patógeno fagocitado sendo processado e apresentado principalmente via moléculas de MHC-II (MHC-II, Major Histocompatibility Complex class II) para as células T CD4 ${ }^{+}$ (Abbas, 2005). Essas células respondem produzindo IFN- $\gamma$ e ativam outras células como as APCs, T CD8 ${ }^{+}$e células B (Abbas, 2005). Na ausência das células T CD4 ${ }^{+}$ou das moléculas de MHC-II camundongos não conseguem controlar a replicação bacteriana (Caruso, Serbina et al., 1999; Saunders, Frank et al., 2002). A transferência adotiva de células T CD4 ${ }^{+}$ 
específicas ao bacilo confere proteção a animais desafiados com M. tuberculosis (Feng e Britton, 2000). Além disso, pacientes infectados com HIV que tem baixa quantidade de células T CD4 ${ }^{+}$apresentam maior susceptibilidade a infecção com M. tuberculosis (Aaron, Saadoun et al., 2004).

Apesar das células $\mathrm{T} \mathrm{CD}^{+}$serem as principais células da imunidade adaptativa no combate ao bacilo $M$. tuberculosis, as células $\mathrm{T} \mathrm{CD} 8^{+}$também apresentam um papel central no combate a esse patógeno, provavelmente pela atividade citotóxica (Stenger, 2001) e produção de IFN- $\gamma$ (Van Pinxteren, Cassidy et al., 2000). Estudos têm demonstrado que o bacilo dentro do fagossomo pode ter acesso ao citoplasma sendo, então, apresentados aos linfócitos T CD8 ${ }^{+}$via MHC de classe I (Serbina e Flynn, 2001). A importância dessas células é evidenciada por experimentos que mostram a presença de células $\mathrm{T} \mathrm{CD} 8^{+}$produtoras de IFN- $\gamma$ no pulmão duas semanas após a infecção (Serbina e Flynn, 1999) e dentro do granuloma onde previne a disseminação de células infectadas (Gonzalez-Juarrero, Turner et al., 2001). Além disso, em humanos infectados é possível isolar grande quantidade de células T CD8 ${ }^{+}$específicas para $M$. tuberculosis indicando que essas células são estimuladas por antígenos micobacterianos (Grotzke e Lewinsohn, 2005).

Já o papel das células B e anticorpos na resposta contra a TB ainda não está bem estabelecido. Alguns pesquisadores demonstram carga bacilar aumentada no baço e fígado de animais deficientes de células B quando infectados (Vordermeier, Venkataprasad et al., 1996). Ao contrário, outros pesquisadores não verificaram nenhuma diferença entre animais deficientes de células B e selvagens quanto ao controle do bacilo M. tuberculosis H37Rv (Johnson, Cooper et al., 1997). Além disso, é evidenciado que anticorpos gerados na vacinação com BCG e na infecção com o patógeno (Brown, Cruz et al., 2003) são irrelevantes no controle da replicação bacteriana. Apesar desse contexto, os anticorpos podem evitar a transmissão do bacilo neutralizando as micobactérias extracelulares presentes em áreas ativas 
de replicação dentro de lesões cavitárias; podem opsonizar $M$. tuberculosis melhorando a fagocitose pelos neutrófilos e macrófagos facilitando a eliminação do patógeno e a ativação de células T (Hoft, 2008).

A imunidade inata e adaptativa culmina na formação do granuloma que consiste de células epitelióides e células gigantes multinucleadas derivadas de macrófagos infectados rodeadas por células $\mathrm{T} \mathrm{CD}^{+}, \mathrm{T} \mathrm{CD}^{+}, \mathrm{NKT}$ e $\mathrm{T} \gamma \delta$ na tentativa de montar uma resposta imunológica eficaz que contenha a infecção (Flynn e Chan, 2001). Em estágios mais tardios ele é rodeado por tecido fibroso e pode persistir por décadas contendo a infecção em um estado de dormência (Skeiky e Sadoff, 2006). Existem importantes evidências de que a manutenção do granuloma é essencial para a prevenção da reativação da doença. Entretanto, a exata natureza das respostas imunológicas que norteiam a reativação da infecção ainda não foi completamente esclarecida (Salgame, 2005). Em indivíduos imunossuprimidos, nos quais o equilíbrio entre o sistema imunológico do hospedeiro e o patógeno é quebrado, ocorre a reativação e, muitas vezes, a disseminação da doença (Gardam, Keystone et al., 2003).

A resposta imunológica na TB é complexa, envolve vários tipos celulares e moléculas, mas em muitos casos não consegue eliminar o bacilo. Como discutido anteriormente para a geração de imunidade contra a TB é necessária a geração de uma resposta Th1. No entanto, surge um paradoxo quando se considera que o bacilo provoca este tipo de resposta logo no início da infecção no homem e na maioria dos modelos animais, mas esses organismos podem desenvolver posteriormente a doença ativa (Rook, Dheda et al., 2005).

Alguns pesquisadores sugerem que a falha na eliminação do patógeno ocorre devido à indução de células T reguladoras (Treg) que inibem as células T efetoras por interação célulacélula ou por produção de IL-10 durante a infecção (Guyot-Revol, Innes et al., 2006; Kursar, Koch et al., 2007). A citocina IL-10 também é produzida por células dendríticas e macrófagos infectados com M. tuberculosis (Hickman, Chan et al., 2002) e por células T de pacientes com 
TB (Gerosa, Nisii et al., 1999). Embora a ausência de IL-10 não aumente a resistência ao bacilo M. tuberculosis (North, 1998) uma super-expressão resulta na reativação da doença (Turner, Gonzalez-Juarrero et al., 2002). Dessa forma, as Tregs podem ter um papel importante na persistência da infecção com M. tuberculosis e corroboram com dados do nosso grupo de que camundongos com maior frequiência de células $\mathrm{T}$ reguladoras no sítio da infecção apresentam uma menor produção de IFN- $\gamma$ e IL-2 por células efetoras $\mathrm{CD}^{+} \mathrm{CD} 25^{-}$e, consequentemente, menor capacidade de controlar o crescimento do bacilo (Paula, 2007).

Outros pesquisadores acreditam que a presença de um padrão Th2 de resposta com produção de IL-4 antes e após a infecção com M. tuberculosis pode prejudicar a eliminação do patógeno. Trabalhos demonstram um aumento na produção de IL-4 em pacientes com TB (Seah e Rook, 2001), bem como a relação desta citocina com a gravidade da doença (JimenezMartinez, Linares et al., 2004). O aumento na expressão dessa citocina pode ser desencadeado por componentes lipídicos e lipoprotéicos presentes na parede celular do bacilo $M$. tuberculosis (Reed, Domenech et al., 2004). A IL-4 prejudica a atividade microbicida devido a redução na atividade da enzima NOS2, diminui a apoptose de células infectadas, além de aumentar a proliferação de células Treg e também aumentar a toxicidade do TNF- $\alpha$ que intensifica a imunopatologia da TB (Rook, 2007). Diante desse quadro, o desenvolvimento das novas vacinas deve levar em consideração a importância do padrão Th1 na resposta contra a TB, mas também a presença desses outros padrões de resposta durante a infecção que influenciam no resultado dessa doença. 


\section{$\underline{\text { Vacinas }}$}

\section{BCG (Bacilo Calmette-Guérin)}

A única vacina atualmente licenciada para a profilaxia contra a TB é a BCG, uma vacina viva atenuada derivada da linhagem de Mycobacterium bovis (Oettinger, Jorgensen et al., 1999). Essa vacina foi descrita em 1921 para a prevenção da tuberculose e adotada pela Organização Mundial da Saúde em 1948. No entanto, desde aquela época muitos trabalhos relataram a ineficácia dessa vacina (Brimnes, 2008). Ela é efetiva na proteção contra a tuberculose grave em crianças, entretanto, ela é relativamente ineficiente contra a doença nos adultos, principalmente em países em desenvolvimento, variando de 0 a $80 \%$ em diferentes populações (Colditz, Brewer et al., 1994; Fine, 1995). Acredita-se que a BCG foi inicialmente adotada por ser uma estratégia barata e por não haver outra forma de prevenção. No entanto, de 1968 até os dias atuais a OMS defende a vacinação com a BCG devido a proteção de crianças contra formas graves da TB (miliar e meningociccica) (Brimnes, 2008).

Além da baixa eficácia, a vacina interfere com o teste tuberculínico (PPD), um importante teste diagnóstico para a TB (Lowrie, Silva et al., 1998). Várias hipóteses têm sido levantadas para explicar a variação na eficácia dessa vacina nos países em desenvolvimento, entre elas estão a desnutrição (Rook, Dheda et al., 2005), variação nas linhagens de BCG usadas (vacinas vivas são difíceis de padronizar) e nas linhagens de $M$. tuberculosis encontradas (Colditz, Brewer et al., 1994; Rook, Dheda et al., 2005), diferenças genéticas e de idade da população alvo, infecções com outras micobactérias (Colditz, Brewer et al., 1994; Rook, Dheda et al., 2005) e a presença de uma resposta Th2 devido a infecções com helmintos (Rook, Dheda et al., 2005). 


\section{Novas vacinas contra Tuberculose}

As novas estratégias vacinais buscam o desenvolvimento de características relacionadas a proteção: células $\mathrm{T} \mathrm{CD}^{+}$de memória produtoras de IFN- $\gamma$ e TNF- $\alpha$ que ativam macrófagos infectados, células $\mathrm{T} \mathrm{CD}^{+}$de memória que possam lisar células infectadas ou levá-las a apoptose, células $\mathrm{T} \gamma \delta$ que tendem a concentrar nas mucosas contribuindo com a proteção inicial e células NKT que também agem no início da infecção inibindo o crescimento micobacteriano (Hoft, 2008).

Antígenos que têm se destacado no desenvolvimento de novas vacinas para a TB são proteínas secretadas que podem estar acessíveis ao reconhecimento imunológico como o complexo antígeno 85 (Ag85) (Weinrich Olsen, Van Pinxteren et al., 2001; Mcshane, Pathan et al., 2004), ESAT6 (Langermans, Doherty et al., 2005) e CFP10 (Berthet, Rasmussen et al., 1998). Outros antígenos promissores são Mtb39 e Mtb32, selecionados por estimular células T em camundongos e humanos (Skeiky, Lodes et al., 1999), proteínas expressas na fase latente (Hoft, 2008) e as proteínas de choque térmico (HSP, Heat Shock Protein) (Lowrie, Tascon et al., 1999).

As novas vacinas e estratégias em desenvolvimento no mundo incluem a utilização de micobactérias vivas e atenuadas; vacinas de subunidade, na qual são usados antígenos micobacterianos; "prime-boost", baseado na administração sucessiva do mesmo antígeno micobacteriano sob dois vetores vacinais diferentes e as vacinas de DNA que envolvem a imunização com DNA contendo uma sequiência gênica que codifica um imunógeno.

Nesse contexto, pesquisadores demonstram melhor proteção com a vacina rBCG30, modificada para superexpressar o antígeno Ag85B, além de terem observado ausência de efeitos colaterais no estudo clínico de fase I (Horwitz e Harth, 2003). Kaufmann e colaboradores (2005) também obtiveram melhores resultados com o rBCG $\Delta \mathrm{UreC}: \mathrm{Hly}^{+}$, capaz de escapar do fagossomo para o citoplasma favorecendo a apresentação via MHC de classe I e 
a apoptose da célula infectada, quando comparado a BCG, dessa forma, iniciaram um estudo clínico de fase I em 2006. Alguns grupos trabalham com M. tuberculosis mutado, no entanto, mesmo que se tenha sucesso com essas vacinas ainda permanece as desvantagens de serem vacinas vivas que podem se reverter na forma virulenta bem como a impossibilidade de usálas em indivíduos imunocomprometidos (Talbot, Perkins et al., 1997; Kamath, 2004; Skeiky e Sadoff, 2006).

Vacinas de subunidade também vêm sendo desenvolvidas com a utilização de antígenos do bacilo $M$. tuberculosis previamente descritos como ativadores de células $\mathrm{T}$ em animais e humanos infectados. Pesquisadores têm usado proteínas fusionadas juntamente com adjuvantes como é o caso do Mtb72F (Skeiky, Alderson et al., 2004) e o Hybrid-1 (Olsen, Hansen et al., 2000) que fusionam os antígenos Mtb39 e Mtb32 e os antígenos 85B e ESAT6, respectivamente. Ambas as construções protegem tão bem quanto a BCG em modelos com camundongos e cobaias (Olsen, Hansen et al., 2000; Skeiky, Alderson et al., 2004). Estudos clínicos de fase I com a vacina Mtb72F nos EUA e na Europa indicam a ausência de efeitos colaterais enquanto os resultados de fase I com a vacina Hybrid-1 ainda não foram publicados, mas já foram iniciados em 2005 (Skeiky e Sadoff, 2006). Apesar dos resultados promissores das vacinas de subunidade, uma desvantagem na utilização de proteínas purificadas é a falta de adjuvantes aprovados para uso em humanos.

Uma estratégia que tem se mostrado promissora é o "prime-boost" que aumenta o repertório de células $\mathrm{T}$ de memória específicas para o antígeno compartilhado entre as vacinas utilizadas no "prime" e no "boost". Essa estratégia tem sido realizada em sua maioria pelo "prime" com a BCG e o "boost" com vacinas de DNA ou vetores vivos que carregam genes para um determinado antígeno de M. tuberculosis. Vários estudos utilizando a BCG como "prime” e vacinas de DNA como "boost" expressando Mtb72F (Brandt, Skeiky et al., 2004), Rv3407 (uma proteína do M. tuberculosis de função desconhecida) (Mollenkopf, Grode et al., 
2004) ou Hsp65 de Mycobacterium leprae (Goncalves, Bonato et al., 2007; Souza, ZarateBlades et al., 2008) tem mostrado proteção superior à BCG sozinha no desafio com $M$. tuberculosis. O regime vacinal de "prime" com BCG e "boost" com Mtb72F em cobaias demonstrou, além de proteção superior à BCG pequena lesão granulomatosa.

O "boost" com vetores virais como MVA85A (MVA, Modified, Vaccinia Ankara Vírus) (Goonetilleke, Mcshane et al., 2003; Mcshane, Pathan et al., 2004) e rAd35-TB (Ad, adenovirus + antígenos Ag85A, Ag85B e TB10.4) (Radosevic, 2006) também vem sendo utilizado com a BCG. A vacina $\mathrm{AAd35-TB}$ juntamente com a BCG tem mostrado proteção no desafio de camundongos com M. tuberculosis bem como aumento no número de células T $\mathrm{CD}^{+}$e $\mathrm{T} \mathrm{CD} 8^{+}$quando comparada a cada estratégia vacinal sozinha. A BCG e o MVA85A já foram utilizados em um estudo clínico de fase I demonstrando resposta aumentada e persistência de células $\mathrm{T} \mathrm{CD} 4^{+}$produtoras de IFN- $\gamma$ quando comparados as vacinas sozinhas.

\section{Vacinas de DNA}

As vacinas de DNA consistem de um plasmídeo contendo um gene de interesse. O plasmídeo é uma molécula de ácido desoxiribonucléico (DNA), circular e dupla fita capaz de se replicar em organismos procariotos. Os plasmídeos utilizados no carreamento de genes normalmente contêm um promotor, o gene de interesse que será transcrito e traduzido, uma seqüência de poliadenilação para eficiente transcrição do RNA (ácido ribonucléico) mensageiro, um gene de resistência a algum antibiótico para seleção e uma origem de replicação (Tonheim, Bogwald et al., 2008).

Por essas características as vacinas de DNA apresentam algumas vantagens como estratégia vacinal, efeito adjuvante inerente, devido a presença de motivos CpGs (Krieg, Love-Homan et al., 1998) que são ligantes de TLRs, produção relativamente simples e grande estabilidade (Kumar e Sercarz, 1996). A vacinação com DNA evita os problemas de proteínas purificadas sob condições desnaturantes, a necessidade de adjuvantes, as 
preocupações com a utilização de microorganismos vivos e vetores virais e oferece a possibilidade de testar diferentes combinações de antígenos, epítopos e genes para citocinas. Além disso, as vacinas de DNA são conhecidas por estimular linfócitos T CD8 ${ }^{+}$citotóxicos (CTLs) importantes no combate a patógenos intracelulares, além de células $\mathrm{T}_{\mathrm{CD}} 4^{+} \mathrm{e}$ linfócitos B (Liu, 2003).

Apesar das vantagens das vacinas de DNA, existe críticas em relação a eficácia da transfecção e a quantidade de proteína sintetizada por essas vacinas que podem ser baixas (Gurunathan, Klinman et al., 2000) induzindo fraca resposta imunológica, o que é visto em vários estudos realizados em humanos (Belakova, Horynova et al., 2007). No entanto, trabalhos iniciais com vacinas de DNA mostram produção de picogramas de proteína por 60 dias sendo suficiente em gerar resposta imunológica (Wolff, Malone et al., 1990), e outros demonstram além de resposta imunológica, expressão do gene por mais de um ano (Wolff, Ludtke et al., 1992; Armengol, Ruiz et al., 2004). Além disso, existe a preocupação quanto a segurança dessa estratégia, entretanto, trabalhos demonstram que as vacinas de DNA são bem toleradas, não desencadeiam auto-imunidade (Santos-Junior, Sartori et al., 2005; Santos Junior, Sartori et al., 2007) e tolerância (Ana Cláudia Pelizon, F Trombone et al., 2007) e não há evidências de integração no genoma (Liu, 2003; Coelho-Castelo, Trombone et al., 2006).

Devido as vantagens dessa estratégia, vacinas de DNA vêm sendo desenvolvidas codificando vários antígenos de Mycobacterium tuberculosis, esses antígenos incluem Ag85 (Ulmer, Liu et al., 1997), ESAT-6, MPT64 (Kamath, Feng et al., 1999) e MPT83 (Zhu, Venkataprasad et al., 1997; Tanghe, Lefevre et al., 1999), muitas delas demonstram similar resultados de proteção quando comparadas à BCG. Além desses antígenos, a proteína Hsp65 de M. leprae também vem sendo utilizada em vacinas de DNA contra a TB demonstrando proteção similar a BCG (Lowrie, Tascon et al., 1994; Lowrie, Silva et al., 1997). 
Epitopos presentes nesses antígenos também vêm sendo utilizados na construção de vacinas de DNA para a TB, Wang e colaboradores em 2004 desenvolveram uma vacina codificando dois epitopos para células $\mathrm{T} \mathrm{CD}^{+}$, um do antígeno MPT64 e outro da proteína de 38kDa de $M$. tuberculosis e demonstraram a indução de células T citotóxicas específicas para o epitopo em camundongos (Wang, Sun et al., 2004). Outros pesquisadores utilizaram oito epitopos de CTLs provenientes de diferentes antígenos de $M$. tuberculosis na montagem de uma vacina de DNA poliepitopo que apresentou forte produção de IFN- $\gamma$ (Bivas-Benita, Van Meijgaarden et al., 2004). Essa é uma estratégia promissora visto a importância das células T $\mathrm{CD}^{+}$no combate ao bacilo $M$. tuberculosis e devido a utilização de apenas parte dos antígenos responsáveis pela estimulação dos linfócitos T.

\section{Vacina de DNAhsp65}

Nosso grupo vem trabalhando com a vacina DNAhsp65 que carrega o gene que codifica a proteína de choque térmico de $65 \mathrm{kDa}$, Hsp65, de M. leprae. Essa proteína é altamente conservada sendo antigenicamente muito similar a Hsp65 de M. tuberculosis (Lowrie, Tascon et al., 1994).

Experimentos com camundongos imunizados com a vacina DNAhsp65, desenvolvida pelo nosso grupo, resultou na prevenção da doença quando esses animais foram desafiados com a linhagem virulenta de M. tuberculosis H37Rv (Lowrie, Tascon et al., 1994; Lowrie, Silva et al., 1997). Durante as etapas de desenvolvimento dessa vacina observou-se que ela também apresentava atividade imunoterapêutica contra a doença já estabelecida (Lowrie, Tascon et al., 1999; Silva, Bonato et al., 2005). Os principais resultados do grupo mostraram que esse produto pode curar os casos crônicos de TB, a doença disseminada, a TB latente e a TB-MDR (Lowrie, Tascon et al., 1999; Silva, Bonato et al., 2005). Além disso, também impede a reativação da doença em animais de laboratório imunossuprimidos e, quando 
associado com quimioterapia reduz significativamente o tempo de tratamento da TB (Silva, Bonato et al., 2005).

Os resultados mostram claramente que a proteção conferida pela vacina está associada com as células $\mathrm{T} \mathrm{CD}^{+} \mathrm{CD} 44^{\text {hi }}$ (Bonato, Lima et al., 1998). Os experimentos de transferência adotiva demonstram que a inoculação de células $\mathrm{T} \mathrm{CD}^{+}$é mais efetiva na proteção contra $M$. tuberculosis do que as $\mathrm{T} \mathrm{CD}^{+}$. Além disso, foi observado também que as células T CD44 ${ }^{\text {lo }}$ foram incapazes de conferir proteção ao contrário das células T CD44 ${ }^{\text {hi }}$. Esses resultados foram confirmados por experimentos mais recentes, no qual camundongos infectados e tratados com a vacina DNAhsp65 possuem como maior efeito a estimulação de células T $\mathrm{CD}^{+}$, produtoras de IFN- $\gamma$ com conseqüente redução na injúria pulmonar (Bonato, Goncalves et al., 2004).

Trabalhos mais recentes do grupo demonstram que a vacina DNAhsp65 quando administrada juntamente com BCG na estratégia de "prime-boost" confere melhor controle na carga bacilar, além de maior produção de IFN- $\gamma$ e melhor preservação do parênquima pulmonar (Goncalves, Bonato et al., 2007; Souza, Zarate-Blades et al., 2008). Além disso, a vacina em associação com lipossoma e administrada pela via intranasal também mostrou redução na carga bacilar, aumento de IFN- $\gamma$ e melhor preservação do pulmão semelhante a quatro doses da vacina administrada intramuscularmente, no entanto, com redução da dose em 16 vezes (Rosada, De La Torre et al., 2008; Souza, Zarate-Blades et al., 2008).

Os resultados obtidos pelo nosso grupo com a vacina DNAhsp65 são muito promissores. A necessidade de melhorar a vacina permanece visando uma estratégia vacinal utilizando a Hsp65 que seja eficiente na resposta imunológica contra a TB com preservação do parênquima pulmonar, estimulação preferencial de células $\mathrm{T} \mathrm{CD}^{+}$, as quais têm demonstrado ter um papel crucial na proteção e terapia da doença, bem como a utilização de menor quantidade de DNA. 
Os bons resultados obtidos com a Hsp65 pode estar no fato das HSPs serem alvos disponíveis para o sistema imunológico por serem expressas em grande quantidade por patógenos durante a infecção, por existir células de memória para epitopos conservados dessas proteínas no repertório humano e, além disso, as HSPs podem ser processadas juntamente com as proteínas e peptídeos aos quais interagem (Van Eden, Van Der Zee et al., 2005). Confirmando essas observações, frequentemente respostas imunológicas contra HSPs de bactérias, fungos, protozoários e helmintos foram detectadas após interação desses patógenos com o hospedeiro (Zugel e Kaufmann, 1999).

No entanto, como as HSPs são proteínas altamente conservadas (Lindquist e Craig, 1988) e a proteína Hsp65 utilizada pelo nosso grupo apresenta 55\% de similaridade com a equivalente proteína de mamíferos (Hsp60) (Feige e Van Eden, 1996) existe a preocupação na possibilidade da vacina desencadear uma resposta auto-imune. Estudos que suportam essa preocupação demonstraram respostas imunológicas celular e humoral contra a Hsp65 bacteriana em modelos experimentais de diabetes (Elias, Reshef et al., 1991), ateroesclerose (Afek, George et al., 2000) e artrite (Danieli, Markovits et al., 1992). No entanto, estudos realizados pelo nosso grupo evidenciaram que a vacina DNAhsp65 quando administrada em camundongos não gera quadro patológico auto-imune em diversos órgãos analisados (Lima, 2006). Além disso, essa mesma vacina usada em linhagens de camundongos com alta e baixa susceptibilidade a reação inflamatória e em modelos experimentais de diabetes não agravou a resposta auto-imune, e ainda mostrou efeito protetor contra artrite e diabetes (Santos-Junior, Sartori et al., 2005; Santos Junior, Sartori et al., 2007).

Embora a vacina DNAhsp65 tenha mostrado segurança e não apresenta efeitos tóxicos em vários modelos experimentais, seria interessante uma formulação vacinal baseada na utilização apenas dos epitopos imunodominantes da proteína Hsp65 que são reconhecidos 
pelas células $\mathrm{T}$ e que não estejam em regiões de grande homologia entre a Hsp65 de micobactérias e a humana.

Mustafá e colaboradores (1999) identificaram três epitopos da Hsp65 (P7-aa 61 ao 75, P13-aa 141 ao 155 e P47-aa 501 ao 515) reconhecidos pelas células T CD4 de indivíduos imunizados com M. leprae (Mustafa, Lundin et al., 1999) que se associam a várias moléculas de HLA, que não são reconhecidos pelas células T de pacientes com doenças auto-imunes e que não estão na região de grande homologia dessa proteína (Quayle, Wilson et al., 1992). Ao contrário, Charo (2001) e colaboradores definiram o primeiro epitopo reconhecido por células $\mathrm{T} \mathrm{CD}^{+}$na seqüência da Hsp65 micobacteriana (Mhsp65(9369)-aa 369 a 377) e demonstraram que existem células $\mathrm{T}$ específicas a esse peptídeo no repertório humano, que ele é gerado naturalmente a partir da proteína Hsp65 e da BCG e que não apresenta reação cruzada com seu correspondente humano.

Apesar dos epítopos citados acima serem bons alvos para as células T e gerarem uma resposta imunológica como no caso do peptídeo Mhsp65(9369) (Charo, Geluk et al., 2001) uma característica inerente a eles é a fraca imunogenicidade na ausência de potentes adjuvantes (Mustafa, Lundin et al., 1999). Entretanto, avanços nas tecnologias de clonagens e expressão têm mostrado que peptídeos podem ser "entregues" de forma altamente imunogênica ao sistema imunológico na ausência de adjuvantes clássicos (Hetzel, Janssen et al., 1998; Lasaro, Alves et al., 2003; Lasaro, Diniz et al., 2005).

\section{Glicoproteína D}

Dentre as investigações que buscam novos sistemas capazes de aumentar a imunogenicidade de proteínas ou peptídeos de interesse está o estudo das propriedades imunológicas de vacinas de DNA baseadas na fusão desses alvos a glicoproteína $\mathrm{D}(\mathrm{gD})$ do 
envoltório celular do vírus herpes humano tipo-1 (HSV-1), que parece ter uma forte atividade imunomoduladora (Lasaro, Alves et al., 2003; Lasaro, Diniz et al., 2005).

A gD é uma glicoproteína presente no envelope do HSV-1 envolvida na infecção, a interação dela com seus receptores ajuda na fusão do vírus com a célula hospedeira (Carfi, Willis et al., 2001; Connolly, Landsburg et al., 2003). A gD apresenta uma porção extracelular com três sítios de ligação a oligossacarídeos e um grampo na porção N-terminal composto de 37 resíduos de aminoácidos responsáveis pela interação ao HVEM (HVEM, Herpesvirus Entry Mediator) (Carfi, Willis et al., 2001; Connolly, Landsburg et al., 2003) expresso em muitas células do sistema imunológico incluindo células T (Montgomery, Warner et al., 1996).

Sabe-se que o HSV-1 infecta facilmente macrófagos e células dendríticas prejudicando a apresentação de antígenos (Pollara, Jones et al., 2004). No entanto, no início da infecção a interação da gD com o HVEM presente nessas células promove a produção de IFN do tipo I,

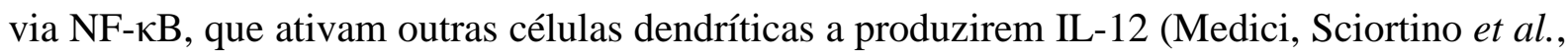
2003; Pollara, Jones et al., 2004). Dessa forma, uma resposta Th1 é montada no combate ao vírus.

O HVEM é uma molécula da superfamília dos receptores de TNF, primeiramente descrito como um ligante da gD (Montgomery, Warner et al., 1996) que pode transmitir sinais estimuladores ou inibidores dependendo do ligante. O HVEM apresenta na sua porção extracelular quatro domínios repetidos ricos em cisteína (CRD, Cysteine-rich Domain) (Bodmer, Schneider et al., 2002) e pode interagir pelos CRD2 e CRD3 com a molécula LIGHT presente nas células T (Rooney, Butrovich et al., 2000). Essa interação promove sinais coestimulatórios na célula $\mathrm{T}$ conduzindo a proliferação e produção de citocinas (Tamada, Shimozaki et al., 2000). Devido ao HVEM ser um membro da família dos TNFRs seus efeitos estimulatórios envolvem serino quinases e os fatores de transcrição NF- $\kappa \mathrm{B}$ e AP- 
1 (AP, Adapter Protein) que promovem a expressão de genes de sobrevivência e de moléculas pro-inflamatórias (Marsters, Ayres et al., 1997; Locksley, Killeen et al., 2001).

O HVEM pode também interagir com o BTLA (BTLA, B- and T-lymphocyte Attenuator) pelo CRD1 (Sedy, Gavrieli et al., 2005), havendo fosforilação de um resíduo de tirosina no imunorreceptor do BTLA que recruta fosfatases responsáveis pela inibição da proliferação das células T (Gavrieli, Watanabe et al., 2003; Gonzalez, Loyet et al., 2005; Sedy, Gavrieli et al., 2005). O BTLA além de ser expresso em células T ativadas e anérgicas também está presente em células B e em menor quantidade nas células dendríticas e macrófagos (Watanabe, Gavrieli et al., 2003; Hurchla, Sedy et al., 2005). Alguns autores descrevem o BTLA como um inibidor constitutivo por ser expresso juntamente com HVEM em células T naive (Hurchla, Sedy et al., 2005).

A gD interage com HVEM no CRD1 se sobrepondo ao sítio de interação HVEMBTLA (Carfi, Willis et al., 2001). Ela compete com o BTLA pelo sítio de interação, podendo assim prejudicar o caminho inibitório HVEM-BTLA, e prejudica a interação HVEM-LIGHT apenas quando esse se encontra ancorado a membrana (Cheung, Humphreys et al., 2005). A quebra no equilíbrio LIGHT-HVEM-BTLA pode ser um mecanismo do vírus do herpes de modular a imunidade sem levar a forte patogenicidade (Cheung, Humphreys et al., 2005).

Diante dessa quebra do equilíbrio LIGHT-HVEM-BTLA provocado pela gD e da

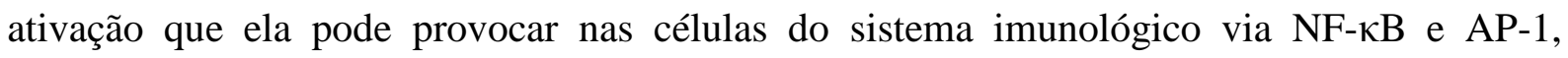
trabalhos vêm mostrando que vacinas de DNA baseadas na fusão de proteínas a gD parece ter uma forte atividade imunomoduladora.

A construção de uma vacina de DNA expressando uma proteína híbrida constituída pela gD do HSV fusionada a CfaB (subunidade estrutural da fimbria CFA/1) de ETEC (Escherichia coli enterotoxigênica) resultou em um aumento na intensidade e longevidade da resposta de anticorpos contra $\mathrm{CfaB}$ em camundongos imunizados (Lasaro, Alves et al., 2003). 
Além dessa vacina, uma construção semelhante utilizando o gene que codifica a gD fusionado ao gene da oncoproteína E7 do HPV-16 desencadeou resultados igualmente positivos (Lasaro, Diniz et al., 2005; Lasaro, Tatsis et al., 2008). Camundongos vacinados com esse DNA tiveram um aumento na ativação de células $\mathrm{T} \mathrm{CD}^{+}$específicas para $\mathrm{E} 7$ que resultou em $100 \%$ de proteção profilática e $40 \%$ de proteção terapêutica em animais desafiados com células tumorais.

Os efeitos imunomoduladores da $\mathrm{gD}$, aumentando a imunogenicidade dos antígenos fusionados a ela, não são totalmente compreendidos, no entanto, parecem estar relacionados a sua interação com o receptor HVEM ativando diferentes células do sistema imunológico como descrito anteriormente. Além disso, segundo Lasaro e colaboradores a fusão de proteínas com a gD não prejudica sua interação com o receptor HVEM (em alguns casos melhora) nem a interação HVEM-LIGHT (Lasaro, Tatsis et al., 2008). Dessa forma, vacinas de DNA baseadas na expressão de antígenos fusionados a $\mathrm{gD}$ podem representar uma estratégia vacinal com grandes potenciais profiláticos e terapêuticos contra infecções e outros tipos de doenças.

Levando-se em consideração as características adjuvantes da proteína gD e a necessidade de se desenvolver uma vacina mais efetiva no combate a TB, que tenha como principal característica uma resposta imunológica mediada por linfócitos $\mathrm{T} \mathrm{CD}^{+}$específicos, não auto-reativos, aventou-se que a construção de uma vacina de DNA contendo o gene que codifica a proteína gD do envoltório celular do HSV-1, fusionada aos epítopos da proteína de choque térmico Hsp65 de M. leprae, poderia ser uma estratégia interessante para o combate a TB. Isso porque essa estratégia associaria as alternativas promissoras do uso da proteína gD e dos epítopos da Hsp65 para a montagem de uma vacina que possa estimular células T CD8 ${ }^{+}$ epítopos-específicas para combater a tuberculose sem o possível e questionável desenvolvimento de uma reação auto-imune. 


\subsection{OBJETIVO}

\subsection{Objetivo Geral}

Desenvolvimento e determinação da imunogenicidade de vacinas de DNA que codificam epitopos da proteína Hsp65 de Mycobacterium leprae, associados ao gene da gD que apresenta capacidade imunoadjuvante.

\subsection{Objetivos específicos}

1. Construir quatro vacinas de DNA utilizando o vetor pVAX1, o gene que codifica a proteína gD do HSV-1 e a seqüência gênica que codifica os cinco epitopos da proteína Hsp65, por meio de técnicas de clonagem molecular;

2. Caracterizar in vitro as vacinas construídas por meio da análise da expressão das proteínas codificadas pelas vacinas em células eucarióticas;

3. Avaliar a imunogenicidade desencadeadas pelas vacinas construídas em camundongos:

3.1 Avaliar a indução de imunidade humoral;

3.2 Avaliar a indução de imunidade celular, com especial ênfase na determinação de células T efetoras (produtoras de INF- $\gamma$ ) específicas ao antígeno utilizado (epitopos da Hsp65). 


\subsection{DELINEAMENTO EXPERIMENTAL}

\subsection{Epitopos e Vacinas}

Epitopos: P7, P13 e P47 epitopos para células T CD4 ${ }^{+}$e Mhsp65(9369) e Mhsp65-10, epitopos para células T CD8 ${ }^{+}$.

Tabela 1 - Epitopos da proteína Hsp65 utilizados no presente trabalho

\begin{tabular}{|c|c|c|c|c|}
\hline Epítopos & & Localização & Seqüência em aas & Seqüência de DNA \\
\hline P7 & E1 & aas $61-75$ & LEDPYEKIGAELVKE & $\begin{array}{l}\text { CTGGAAGACCCCTACGAGAAGATC } \\
\text { GGAGCCGAGCTGGTGAAGGAA }\end{array}$ \\
\hline P13 & E2 & aas $141-155$ & EQIAATAAISAGDQS & $\begin{array}{l}\text { GAGCAGATTGCTGCCACCGCAGCC } \\
\text { АTCTCTGCCGGAGACCAATCC }\end{array}$ \\
\hline P47 & E3 & aas $501-515$ & LQNAASIAGLFLTTE & $\begin{array}{l}\text { TTGCAGAACGCTGCATCCATTGCC } \\
\text { GGCCTCTTCCTGACCACAGAG }\end{array}$ \\
\hline Mhsp65-9 & E4 & aas $369-377$ & KLAGGVAVI & $\begin{array}{l}\text { AAACTGGCAGGCGGAGTGGCTGTG } \\
\text { ATC }\end{array}$ \\
\hline Mhsp65-10 & E5 & aas 97-106 & ALVKEGLRNV & $\begin{array}{l}\text { GCCCTGGTGAAGGAAGGACTTCGC } \\
\text { AACGTG }\end{array}$ \\
\hline
\end{tabular}

\section{Vacinas:}

- pVAXgD (plasmídeo pVAX + gene da glicoproteína D do HSV-1);

- pVAXgDVac1AA (plasmídeo pVAX + a gD + os 5 epítopos da Hsp65 clonados no sítio da enzima ApaI no interior da gD);

- pVAXgDVac1PA (plasmídeo pVAX + a gD sem sua porção central + os 5 epítopos da Hsp65 clonados entre os sítios das enzimas $P v u I I$ e ApaI no interior da gD);

- pVAXgDVac2 (plasmídeo pVAX+ a gD + 5 epítopos da Hsp65 em duplicata clonados no sítio da enzima ApaI no interior da gD); 


\begin{tabular}{|c|c|c|c|c|c|c|c|c|c|}
\hline \multicolumn{10}{|c|}{ Hsp65 } \\
\hline E1 & E5 & I & & & & E4 & & & \\
\hline & Vac1 & E1 & E: & E3 & E4 & E5 & & & \\
\hline Vac2 & $\begin{array}{ll}\text { E1 } & \text { E2 }\end{array}$ & $\mathrm{E} 3$ & E4 & E5 & E1 & E2 & E3 & E4 & E5 \\
\hline
\end{tabular}
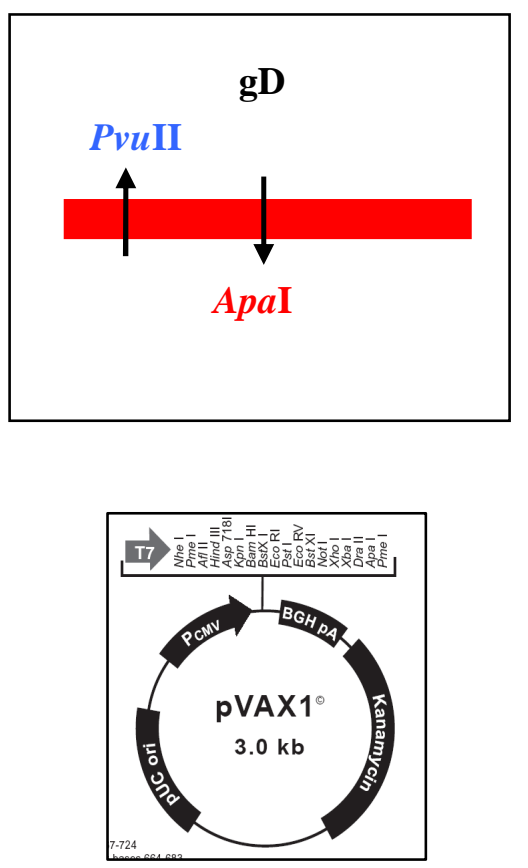

Tabela 2 - Seqüência do DNA e proteína Vac1 (epitopos E1-E2-E3-E4-E5 em seqüência)

\begin{tabular}{|c|l|}
\hline $\begin{array}{c}\text { Vac1 } \\
\text { (DNA) }\end{array}$ & $\begin{array}{l}\text { CTGGAAGACCCCTACGAGAAGATCGGAGCCGAGCTGGTGAAGGAAGAGCAGATTGCTGCCACCGCAGCCATC } \\
\text { TCTGCGGAGACCAATCCTTGCAGAACGCTGCATCCATTGCCGGCCTCTTCCTGACCACAGAGAAACTGGCA } \\
\text { GGCGGATGGCTGTGATCGCCCTGGTGAAGGAAGGACTTCGCAACGTG }\end{array}$ \\
\hline $\begin{array}{c}\text { Vac1 } \\
\text { (proteína) }\end{array}$ & LEDYEIGAELVKEEIAATAAISAGDQSLQNAAS IAGLFLTTEKLAGGVAVIALVKEGLRNV \\
\hline
\end{tabular}

Tabela 3 - Seqüência do DNA e proteína Vac2 (epitopos E1-E2-E3-E4-E5-E1-E2-E3-E4-E5 em seqüência)

\begin{tabular}{|c|l|}
\hline Vac2 & CTGGAAGACCCCTACGAGAAGATCGGAGCCGAGCTGGTGAAGGAAGAGCAGATTGCTGCCACCGCAGCCATC \\
(DNA) & GGCGGAGTGGCTGTGATCGCCCTGGTGAAGGAAGGACTTCGCAACGTGGGATCCCTGGAAGACCCCTACGAG \\
& AAGATCGGAGCCGAGCTGGTGAAGGAAGAGCAGATTGCTGCCACCGCAGCCATCTCTGCCGGAGACCAATCC \\
& TTGCAGAACGCTGCATCCATTGCCGGCTCTTCCTGACCACAGAGAAACTGGCAGGCGGAGGGCTGTGATC \\
GCCCTGGTGAAGGAAGGACTTCGCAACGTG
\end{tabular}




\subsection{Delineamento}

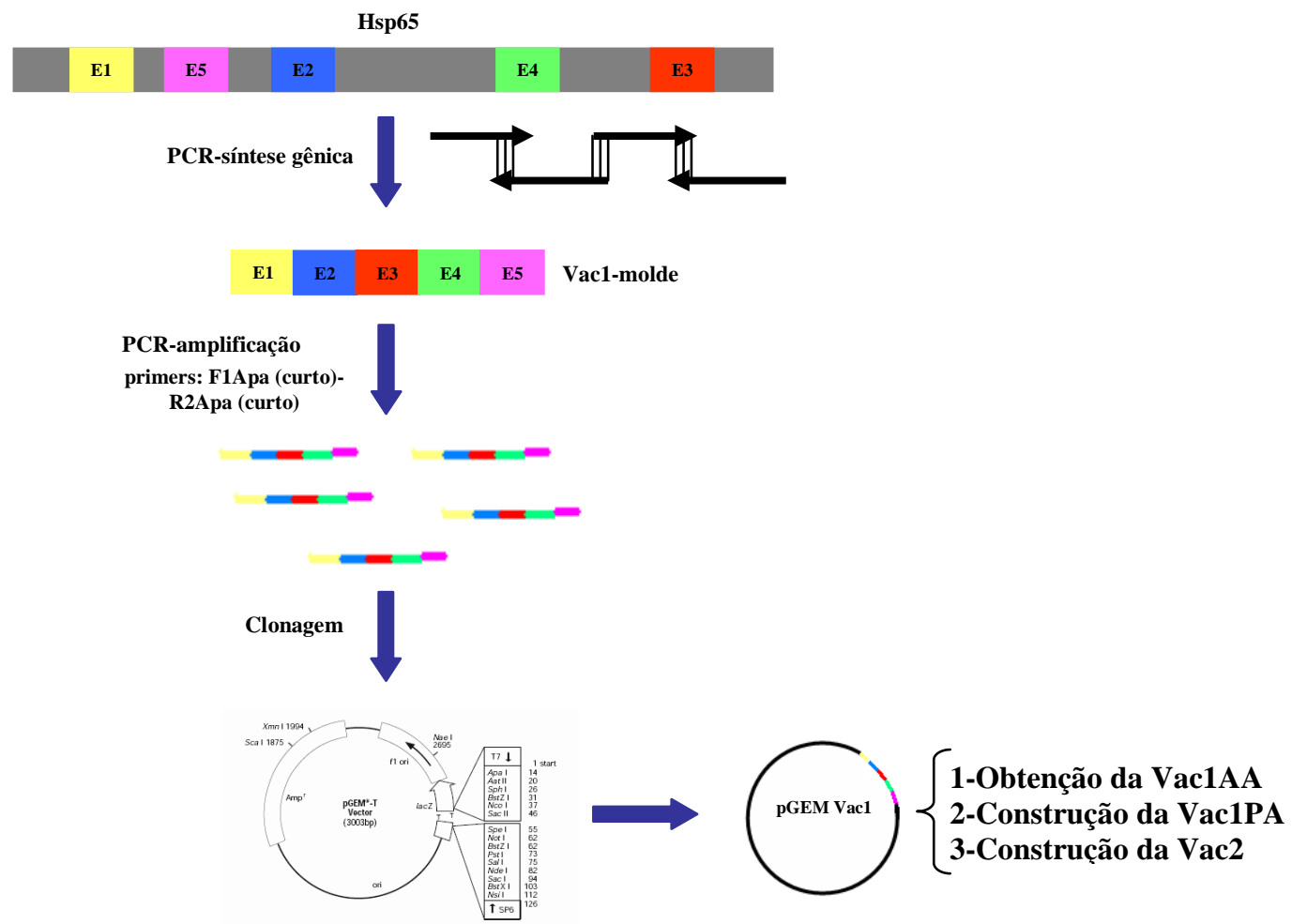

1-Obtenção da Vac1AA

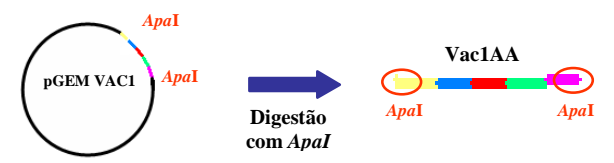

2-Construção da Vac1PA

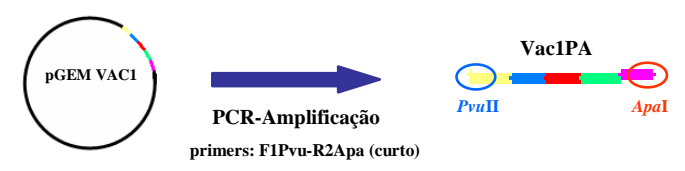

3-Construção da Vac2

$$
\bigcirc_{\text {ApaI }} \stackrel{\text { Vac1AB }}{=}
$$
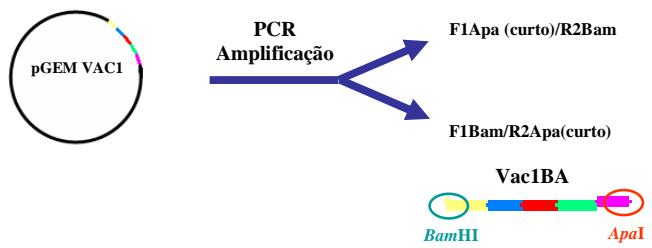

Clivagem com Bam HI e

Ligação dos fragmentos

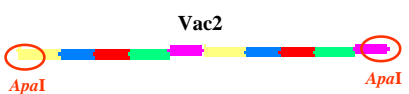



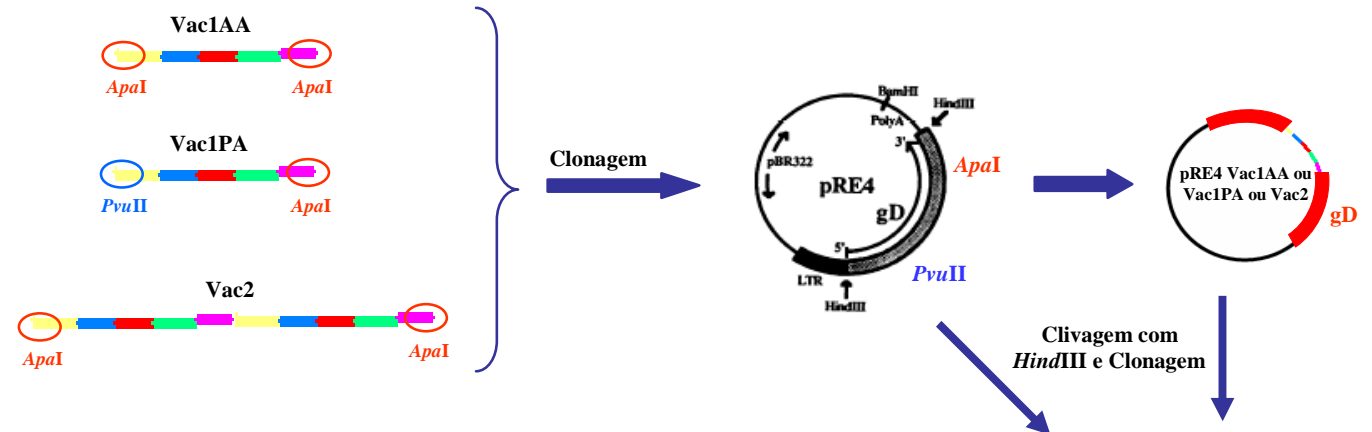

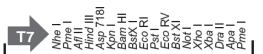
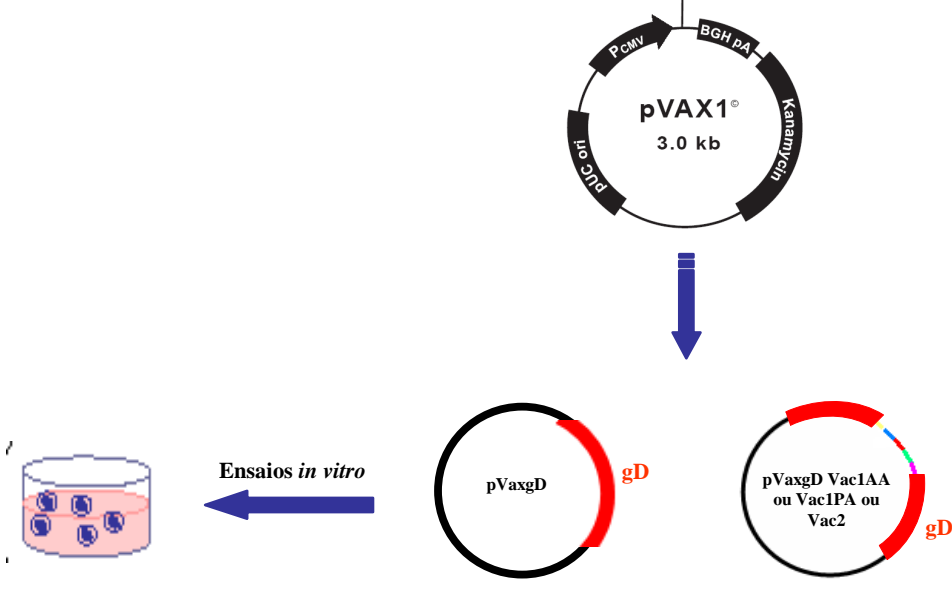

\section{Ensaios in vivo}

Imunização
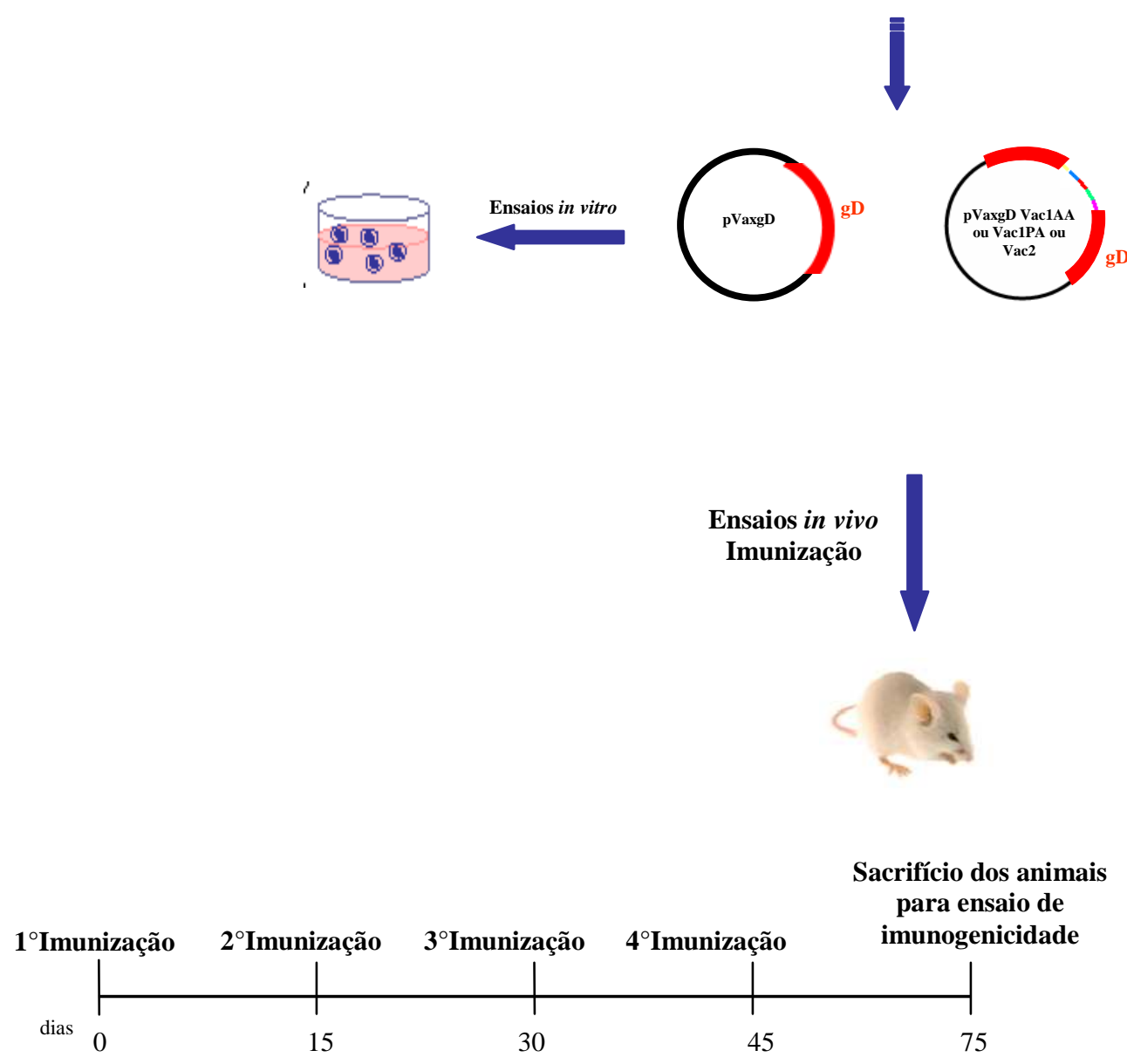


\subsection{MATERIAL E MÉTODOS}

\section{Considerações iniciais}

» Todas as reações realizadas neste trabalho quando necessárias foram completadas com água Milli-Q estéril;

» Os termocicladores utilizados no decorrer deste trabalho foram Eppendorf e MJ Research (PTC-100 ${ }^{\mathrm{TM}}$ );

» Todas as quantificações plasmidiais e dos fragmentos utilizados durante a montagem das vacinas foram feitas em gel de agarose a 1\% (Invitrogen);

» As purificações plasmidiais foram realizadas por lise alcalina com SDS (Duodecil Sulfato de Sódio) (Sambrook, 1989);

»As transformações em bactérias foram feitas pelo método de choque térmico (Sambrook, 1989) e plaqueadas em meio ágar LB (USB), contendo o antibiótico apropriado;

» As bactérias competentes utilizadas nas transformações foram preparadas com cloreto de cálcio, segundo Sambrook (1989);

» Os antibióticos utilizados foram ampicilina (100mg/mL) (ARISTON) e canamicina (50mg/mL) (Gibco-BRL) nas concentrações finais de $100 \mu \mathrm{g} / \mathrm{mL}$ e $50 \mu \mathrm{g} / \mathrm{mL}$, respectivamente;

» As reações em Cadeia da Polimerase realizadas nas construções plasmidiais deste projeto seguiram em sua maioria o programa denominado VAC: $94^{\circ} \mathrm{C}-5$ minutos, 24 ciclos de $94^{\circ} \mathrm{C}$ - 1 minuto (desnaturação), $57^{\circ} \mathrm{C}-1$ minuto (anelamento ou TM-temperatura de melting), $72^{\circ} \mathrm{C}-1$ minuto (extensão) finalizando com $72^{\circ} \mathrm{C}-5$ minutos, as variações dentro desse programa foram na temperatura de anelamento (dependente do oligonucleotídeo utilizado) e tempo de extensão (dependente do tamanho do fragmento a ser amplificado) e foram citadas no decorrer do material e métodos; 
» As amostras analisadas em gel de agarose foram acrescidas de tampão da amostra concentrado 6 vezes $(0,25 \%$ azul de bromofenol; $40 \%$ de sacarose em água) de forma a ficar em uma concentração final de $0,042 \%$ de azul de bromofenol e 6,67\% de sacarose e submetidas a eletroforese em tampão TAE (Tris-acetato a 40mM; EDTA a $1 \mathrm{mM} \mathrm{pH} \mathrm{8,3),}$ voltagem $50-60 \mathrm{~V}$. Os géis foram corados com $0,5 \mathrm{mg} / \mathrm{mL}$ de brometo de etídio (Gibco-BRL) e a visualização dos fragmentos feita em luz ultravioleta no aparelho Image Master VDS (GE Healthcare Biotech).

» Todas as reações de seqüenciamento realizadas neste trabalho foram feitas no Centro de Estudo do Genoma Humano-USP/São Paulo utilizando-se o seqüenciador MegaBACE 1000 (GE Healthcare) e DYEnamic ET Dye Terminator Kit.

» Todas as amostras analisadas em gel de poliacrilamida foram acrescidas de tampão de amostra (150mM de Tris-Cl, pH 6,8, 6\% de SDS, 0,3\% de bromophenol blue, 30\% de glicerol e 300mM de $\beta$-mercaptoethanol) e submetidas a eletroforese em tampão tricina (Tris a 0,1M, Tricina a $0,1 \mathrm{M}$, SDS a $0,1 \%, \mathrm{pH} 8,25)$, voltagem $100 \mathrm{~V}$. O gel foi corado com Coomassie (0,2\% de Coomassie Brilliant Blue R-250, 50\% de metanol e 10\% de ácido acético) e a visualização feita no aparelho Image Master VDS.

\section{$\underline{4.1 \text { Construção da vacina } \mathrm{pVAXgD}}$}

\subsubsection{Clivagem do vetor $\mathrm{pRE} 4$}

O vetor pRE4 (Figura 1) (gentilmente cedido pelo Professor Luis Carlos de Souza Ferreira - ICBII/USP - São Paulo) é um plasmídeo que apresenta a sequiência de nucleotídeos responsável pela expressão da proteína $\mathrm{gD}$. Essa proteína apresenta em seu interior sítios únicos de restrição para as enzimas $P v u \mathrm{II}$ e $A p a \mathrm{I}$, onde podem ser inseridos peptídeos, e está flanqueada pelo sítio de restrição da enzima HindIII podendo ser retirada desse vetor e 
clonada em outro. Dessa forma, o vetor pRE4 foi utilizado em nossas quatro construções vacinais, sendo que em uma delas a seqüência de nucleotídeos da proteína gD foi retirada desse vetor para clonagem no vetor pVAX1 (Invitrogen) (Figura 2) e nas outras o vetor pRE4 foi utilizado com intuito de fusionar os fragmentos de interesse a sequiência de nucleotídeos da proteína gD.

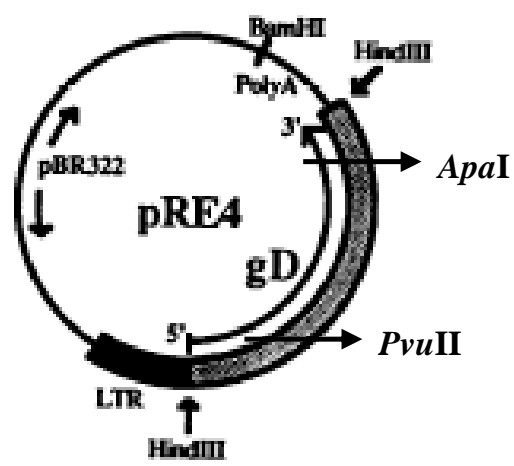

Figura 1: Representação esquemática do plasmídeo pRE4. Em destaque os sítios de restrição das enzimas ApaI e PvuII, respectivamente. Plasmídeo utilizado na retirada do fragmento gD e nas construções dos fragmentos gDVac1AA, gDVac1PA e gDVac2.

Para a clonagem da seqüência que codifica a proteína gD no vetor $\mathrm{pVAX}$ o plasmídeo pRE4 (Figura 1) foi clivado com a enzima HindIII e o fragmento liberado (gD) foi posteriormente clonado no vetor pVAX (Figura 2) para construção da vacina pVAXgD. Para isto, $12 \mu \mathrm{g}$ do vetor pRE4 foi clivado com 15 unidades da enzima HindIII (Invitrogen) juntamente com o tampão React2 em um volume final de $50 \mu \mathrm{L}$ a $37^{\circ} \mathrm{C}$ por 16 horas. A reação de digestão foi analisada em gel de agarose a $1 \%$ e o fragmento da $\mathrm{gD}$ foi purificado utilizando-se o Wizard SV Gel and PCR Clean-Up System (Promega).

\subsubsection{Clivagem do vetor $\mathrm{pVAX}$}

O pVAX1 (Figura 2) é um vetor plasmidial usado no desenvolvimento de vacinas de DNA e foi utilizado em nossas construções vacinais. 


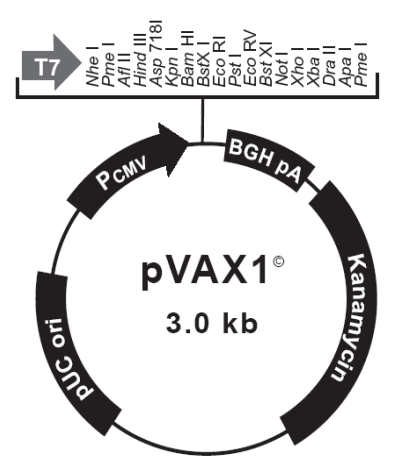

Figura 2: Plasmídeo pVAX1..Utilizado nas construções vacinais.

Dessa forma, $18 \mu \mathrm{g}$ do vetor pVAX (Figura 2) foi digerido com 40 unidades da enzima HindIII, tampão React 2 em um volume final de $50 \mu \mathrm{L}$ a $37^{\circ} \mathrm{C}$ por 16 horas. A digestão foi analisada em gel de agarose a $1 \%$, e em seguida o vetor foi desfosforilado pela adição de 150 unidades da enzima BAP (Bacterial Alkaline Phosphatase) (Invitrogen) em uma reação mantida a $65^{\circ} \mathrm{C}$ por 1 hora com posterior purificação utilizando-se o Wizard SV Gel and PCR Clean-Up System.

\subsubsection{Clonagem da gD no vetor $\mathrm{pVAX}$}

$\mathrm{O}$ vetor $\mathrm{pVAX}$ digerido com a enzima HindIII conforme descrito no item anterior foi usado na ligação com a seqüência da proteína $\mathrm{gD}$, 120ng do vetor $\mathrm{pVAX}$ e 160ng do fragmento gD foram ligados pela adição de 1 unidade da T4 DNA ligase (Invitrogen) e tampão da enzima em uma reação realizada a $4^{\circ} \mathrm{C}$ por 16 horas, no volume final de $15 \mu \mathrm{L}$.

Metade do volume da ligação foi utilizada na transformação de células E. coli Top10 (Invitrogen) competentes que foram plaqueadas em ágar LB contendo $50 \mu \mathrm{g} / \mathrm{mL}$ do antibiótico canamicina, para o qual o vetor pVAX apresenta gene de resistência, dessa forma, realiza-se uma primeira seleção, garantindo que apenas bactérias transformadas com esse vetor cresçam no meio de seleção utilizado. 
Os plasmídeos de dez colônias da ligação entre $\mathrm{pVAX}$ e $\mathrm{gD}$ foram extraídos e submetidos a reação de clivagem. Utilizou-se 600ng de cada plasmídeo das dez colônias separadamente, 2 unidades das enzimas PvuII** (Fermentas) e Not I** (Invitrogen) juntamente com o tampão universal (Fischer) em um volume final de $20 \mu \mathrm{L}$ a $37^{\circ} \mathrm{C}$ por 16 horas. O produto da digestão foi analisado em gel de agarose a $1 \%$.

**A enzima $P v u I I$ digere no sítio dentro da gD e a NotI no interior do pVAX, assim é possível verificar a presença e direção do fragmento gD no interior do pVAX.

Os plasmídeos de dois clones dessa ligação também foram digeridos com as enzimas HindIII** e ApaI** (Fermentas) separadamente. Setecentos e cinqüenta nanogramas de cada clone foi clivado com 10 unidades da enzima HindIII e tampão React2 e 750ng de cada clone foi digerido com 10 unidades da enzima ApaI e tampão B. Ambas reações foram realizadas em uma volume final de $20 \mu \mathrm{L}$ a $37^{\circ} \mathrm{C}$ por 16 horas. As digestões foram analisadas em gel de agarose a $1 \%$.

**A enzima HindIIII libera o fragmento gD do vetor pVAX, caso tenha ocorrido ligação entre eles. A enzima ApaI digere no interior da gD e do pVAX, dessa forma, é possível confirmar a presença do fragmento e sua direção.

Uma nova ligação foi feita com 120ng do vetor pVAX, 160ng da gD, 1 unidade da T4 DNA ligase e tampão da enzima em uma reação realizada a $4^{\circ} \mathrm{C}$ por 16 horas, no volume final de $15 \mu \mathrm{L}$. Metade do volume da ligação foi utilizada na transformação de células de $E$. coli Top10 competentes que foram plaqueadas em ágar LB contendo $50 \mu \mathrm{g} / \mathrm{mL}$ do antibiótico canamicina.

A nova seleção do plasmídeo recombinante $\mathrm{pVAXgD}$ foi feita inicialmente realizando uma PCR de colônias que consiste em uma reação de amplificação utilizando-se como fonte de DNA uma suspensão bacteriana em água. Essa suspensão é feita picando-se uma colônia com um palito de dente estéril, dissolvendo-a na água e fervendo por 5 minutos, assim, 10 
colônias de bactéria da transformação citada anteriormente foram "palitadas" separadamente e diluídas em $20 \mu \mathrm{L}$ de água estéril. Para a reação utilizou-se, então, $5 \mu \mathrm{L}$ da suspensão bacteriana, $0.1 \mu \mathrm{M}$ de cada oligonucleotídeo (T7 e FgDApa**), 0,2mM de cada deoxirribonucleotídeo (dNTPs), tampão da enzima, $1,5 \mathrm{mM}$ de $\mathrm{MgCl}_{2}$ e 1 unidade da enzima Taq DNA polimerase (Invitrogen) em um volume final de $20 \mu \mathrm{L}$ (programa VAC [TM de $\left.50^{\circ} \mathrm{C}\right]$ ). O produto da PCR foi analisado em gel de agarose a $1 \%$.

T7 promoter: 5' TAATACGACTCACTATAGGG 3'

FgDApa: 5' CATCCCCGAGAACCAGCG 3'

**O primer T7 hibridiza no vetor pVAX e o FgDApa no interior da gD sendo possível avaliar a presença e direção do fragmento gD no interior desse vetor.

Das dez colônias submetidas a PCR, quatro tiveram seus plasmídeos extraídos juntamente com outras cinco novas colônias e estes foram submetidos a duas reações de clivagem, uma com 800ng de cada plasmídeo digerido separadamente com 5 unidades das enzimas $P v u I I$ e $N o t$ I juntamente com tampão universal em uma reação final de $30 \mu \mathrm{L}$ e a outra com 300ng de cada plasmídeo, 2 unidades da enzima HindIII e tampão React2 em um volume final de $10 \mu \mathrm{L}$. Após incubação por 16 horas a $37^{\circ} \mathrm{C}$, as digestões foram analisadas em gel de agarose a $1 \%$. Um dos dez clones $\mathrm{pVAXgD}$ foi ainda submetido a uma reação de clivagem com a enzima $A p a \mathrm{I}, 1 \mu \mathrm{g}$ do clone foi digerido com 5 unidades da enzima juntamente com tampão B em uma reação final de $20 \mu \mathrm{L}$ a $37^{\circ} \mathrm{C}$ por 16 horas. A digestão foi analisada em gel de agarose a $1 \%$.

A partir dos resultados obtidos com a análise de restrição, três plasmídeos recombinantes $\mathrm{pVAXgD}$ foram analisados por seqüenciamento utilizando-se os oligonucleotídeos T7, BGH e FgDApaseq para confirmação da seqüência. Posteriormente um deles foi utilizado nos ensaios in vitro e in vivo.

BGH: 5'TAGAAGGCACAGTCGAGG 3' 


\subsection{Construcão e amplificacão do molde Vac1}

As sequiências dos epitopos (Tabela 1-Delineamento Experimental) utilizados neste projeto estão distribuídas dentro da seqüência do gene hsp65 aleatoriamente, dessa forma, foi necessário a construção de um molde (Tabela 2-Delineamento Experimental) por meio de uma síntese gênica utilizando a PCR.

Para a construção do molde Vac1 foram utilizados quatro primers "desenhados" com códons otimizados de forma que cobrissem toda sequiência a ser construída, a seguir estão às sequiências dos oligonucleotídeos e do molde a ser construído:

\section{Oligonucleotídeos utilizados:}

F1Pvu(1-64)

5`ATCAGCTGCTGGAAGACCCCTACGAGAAGATCGGAGCCGAGCTGGTGAAGGAAGAGCAGATTGC 3’

R1 (47-11)

5'CAGCGTTCTGCAAGGATTGGTCTCCGGCAGAGATGGCTGCGGTGGCAGCAATCTGCTCTTCCTTC3'

F2(95-159)

5`ATCCTTGCAGAACGCTGCATCCATTGCCGGCCTCTTCCTGACCACAGAGAAACTGGCAGGCGGAG3’

R2Apa(143-208)

5’AT $\underline{G G C C C C A C G T T G C G A A G T C C T T C C T T C A C C A G G G C G A T C A C A G C C A C T C C G C C T G C C A G T T T C}$ 3'

\section{Sequiência a ser construída:}

ATCAGCTGCTGGAAGACCCCTACGAGAAGATCGGAGCCGAGCTGGTGAAGgAAGAGCAGATTGCTGCCA CCGCAGCCATCTCTGCCGGAGACCAATCCTTGCAGAACGCTGCATCCATTGCCGGCCTCTTCCTGACCA CAGAGAAACTGGCAGgCGgAGTGgCTGTGATCGCCCTGGTGAAGGAAGgACTTCGCAACGTG $\underline{G G C C C}$ AT

A sequiência em destaque (negrito) é a seqüência dos cinco epitopos que compõe a chamada Vac1 (Tabela 2), as seqüências sublinhadas são os sítios de restrição para as enzimas PvuII e ApaI, respectivamente, inseridas nos oligonucleotídeos F1Pvu e R2Apa e utilizadas para posterior clonagem, os dois nucleotídeos a mais (AT) antes e depois desses sítios são apenas nucleotídeos de ancoragem para as enzimas.

Na reação foram utilizados $0,4 \mu \mathrm{M}$ de cada oligonucleotídeo, $0,2 \mathrm{mM}$ de cada dNTPs, tampão da reação, $1,5 \mathrm{mM}$ de $\mathrm{MgCl}_{2}$ e 2,5 unidades da enzima Taq DNA polimerase; a reação foi feita em $25 \mu \mathrm{L}$ utilizando o programa: $94^{\circ} \mathrm{C}-2$ minutos, 25 ciclos de $94^{\circ} \mathrm{C}-30$ segundos, $50^{\circ} / 54,2^{\circ} / 61^{\circ} / 65^{\circ} \mathrm{C}$ (utilizou-se um gradiente para o TM) -20 segundos, $68^{\circ} \mathrm{C}-20$ segundos, 
finalizando com $68^{\circ} \mathrm{C}-3$ minutos. Os produtos de amplificação foram analisados em gel de agarose a $2 \%$ e usados como molde para amplificação do fragmento Vac1.

Tendo construído o molde, o próximo passo foi amplificar essa sequiência para clonagem no vetor pGEM-T (Promega). Na reação de amplificação era necessário utilizar apenas os oligonucleotídeos F1Pvu e R2Apa (usados na reação anterior) para obter maior quantidade da seqüência molde, no entanto, como houve dificuldade em amplificar a sequiência utilizando esses primers, provavelmente por causa do tamanho (64-66 pares de base), a amplificação foi realizada com outros oligonucleotídeos. Nessa reação de amplificação os iniciadores utilizados foram:

\section{F1Apa(curto) 5’A $\underline{G G G C C C T G G A A G A C C C C T A C G A G ~ 3 '}$ R2Apa(curto) 5'ATGGGCCCCACGTTGCGAAG 3'}

O sítio de restrição da enzima ApaI foi inserido nos oligonucleotídeos sense e antisense (regiões sublinhadas) para posterior clonagem. Na reação de amplificação além dos $100 \mu \mathrm{M}$ de cada oligonucleotídeo foi utilizado $2 \mu \mathrm{L}$ do molde obtido na reação anterior com o TM 54,2 $, 0,2 \mathrm{mM}$ de cada dNTPs, tampão da reação, $1,5 \mathrm{mM}$ de $\mathrm{MgCl}_{2}$ e 2,5 unidades da enzima Taq DNA polimerase; a reação foi feita em $25 \mu \mathrm{L}$ utilizando o programa: $94^{\circ} \mathrm{C}-2$ minutos, 10 ciclos de $94^{\circ} \mathrm{C}-30$ segundos, $50^{\circ} \mathrm{C}-20$ segundos, $68^{\circ} \mathrm{C}-20$ segundos seguidos de 15 ciclos de $94^{\circ} \mathrm{C}-30$ segundos, $55^{\circ} \mathrm{C}-20$ segundos, $68^{\circ} \mathrm{C}-20$ segundos finalizando com $68^{\circ} \mathrm{C}-5$ minutos. O produto de amplificação denominado Vac1AA (apresenta o sítio da enzima ApaI nas duas extremidades 5' e 3') foi analisado em gel de agarose a $2 \%$ e purificado utilizando-se o Wizard SV Gel and PCR Clean-Up System.

\subsection{Clonagem do fragmento Vac1AA no vetor pGEM-T}

O fragmento amplificado após purificação foi clonado no plasmídeo pGEM-T (Figura 3) pela reação de ligação, feita a $4^{\circ} \mathrm{C}$ por 16 horas, utilizando-se 90ng do amplificado 
(Vac1AA), 50ng do vetor pGEM-T, tampão da enzima e 3 unidades da enzima ligase (próprios do kit Promega) em um volume final de $21 \mu \mathrm{L}$.

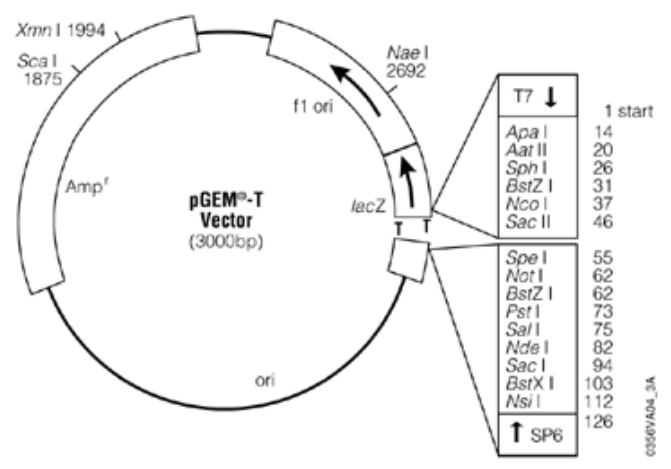

Figura 3: Plasmídeo pGEM-T. Usado como vetor de propagação.

A mistura de ligação entre pGEM e Vac1AA foi utilizada para transformar células de E. coli Top10 competentes, das quais foram selecionadas aquelas contendo o plasmídeo recombinante pGEMVac1AA. A seleção foi feita utilizando-se o antibiótico ampicilina (para

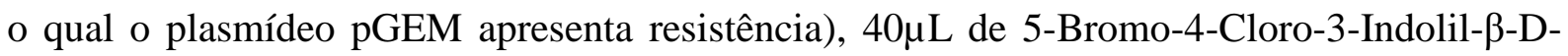

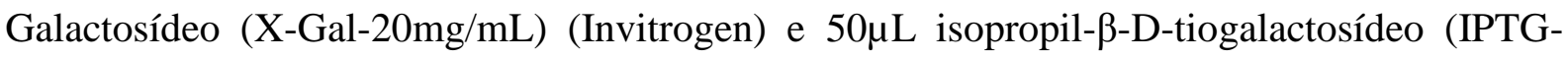
200mM) (Invitrogen) para seleção pela cor das colônias.

Devido a possível presença de falsos recombinantes, os plasmídeos de dez colônias brancas da ligação entre pGEM e Vac1AA foram extraídos e submetidos à reação de clivagem. A reação foi feita utilizando-se $1 \mu \mathrm{g}$ do plasmídeo extraído de cada colônia, tampão B, 5 unidades da enzima ApaI em uma reação final de $10 \mu \mathrm{L}$ a $37^{\circ} \mathrm{C}$ por 16 horas. A digestão foi analisada em gel de agarose a $2 \%$. Além da reação de clivagem, seis plasmídeos foram seqüenciados utilizando-se o oligonucleotídeo T7 para confirmar a presença do fragmento Vac1AA e sua sequiência. Após o seqüenciamento um dos clones pGEMVac1AA foi selecionado para ser utilizado como molde nas construções dos fragmentos Vac1AA, Vac1PA e Vac2. 


\section{$\underline{4.4 \text { Construcão da vacina pVAXgDVac1AA }}$}

\subsubsection{Obtenção do fragmento Vac1AA}

Após o seqüenciamento um dos clones pGEMVac1AA foi selecionado para ser

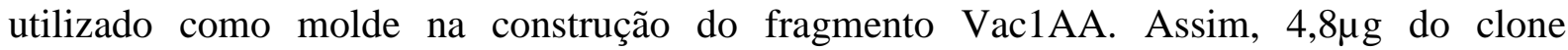
pGEMVac1AA foi utilizado na reação de clivagem com tampão B e 30 unidades da enzima ApaI, em uma reação final de $80 \mu \mathrm{L}$ incubada a $37^{\circ} \mathrm{C}$ por 16 horas. A digestão foi analisada em gel de agarose a $1 \%$ e o fragmento de interesse purificado utilizando-se o Wizard SV Gel and PCR Clean-Up System.

\subsubsection{Construção do fragmento gDVac1AA}

\subsubsection{Clivagem do vetor pRE4}

O vetor pRE4 (Figura 1) (4,8 $\mu \mathrm{g})$, foi, então, digerido com 10 unidades da enzima ApaI juntamente com tampão B em uma reação de $50 \mu \mathrm{L}$, a $37^{\circ} \mathrm{C}$ por 16 horas para posterior clonagem do fragmento Vac1AA nesse plasmídeo. O vetor pRE4 após a digestão foi analisado em gel de agarose a 1\%, purificado utilizando-se o Wizard SV Gel and PCR CleanUp System. Em seguida, o vetor foi desfosforilado em uma reação com $1 \mu \mathrm{g}$ do pRE4, tampão BAP, 150 unidades da enzima BAP, a $65^{\circ} \mathrm{C}$ por 1 hora, com posterior purificação utilizandose novamente o Wizard SV Gel and PCR Clean-Up System.

\subsubsection{Construção do vetor pRE4Vac1AA}

O fragmento Vac1AA e o vetor pRE4 clivados com a enzima ApaI foram utilizados na seguinte reação de ligação: 100ng do vetor, 180ng do inserto, tampão da enzima e 1 unidade da T4 DNA ligase, em uma reação final de $15 \mu \mathrm{L}$, realizada a $4^{\circ} \mathrm{C}$ por 16 horas.

Metade do volume da ligação foi utilizada na transformação de células de $E$. coli Top10 competentes que foram plaqueadas em ágar LB contendo $100 \mu \mathrm{g} / \mathrm{mL}$ do antibiótico 
ampicilina. Dessa forma, realiza-se uma primeira seleção, pois o vetor pRE4 apresenta gene de resistência a esse antibiótico.

Plasmídeos de quatro colônias da ligação entre pRE4 e Vac1AA foram extraídos e submetidos à digestão e a PCR para verificação da presença do inserto Vac1AA. Quinhentos nanogramas de cada clone foi digerido com 3 unidades da enzima ApaI, tampão B, em um volume final de $15 \mu \mathrm{L}$, a $37^{\circ} \mathrm{C}$ por 8 horas.

Além da reação de clivagem, foi realizada a PCR utilizando-se o programa VAC (TM de $60^{\circ} \mathrm{C}$ ) em um volume final de $20 \mu \mathrm{L}$, utilizando-se 50 ng de plasmídeo como molde, $0,1 \mu \mathrm{M}$ de cada oligonucleotídeo**, $0,2 \mathrm{mM}$ de cada dNTPs, tampão da enzima, $1,5 \mathrm{mM}$ de $\mathrm{MgCl}_{2} \mathrm{e}$ 1,5 unidades da enzima Taq DNA polimerase.

**Para cada plasmídeo foi realizada duas PCRs, uma utilizando os oligonucleotídeos FgDApa e R2Apa(curto) que hibridizam dentro da gD próximo ao sítio ApaI e no final do inserto, respectivamente, indicando a direção do inserto Vac1AA no interior da gD. A segunda reação foi realizada com os oligonucleotídeos FgDApa e RgDApa ambos anelam dentro da gD próximo ao sítio ApaI, um sendo sense e o outro antisense, respectivamente. Dessa forma, é possível verificar a quantidade de fragmentos Vac1AA que se ligaram no interior da gD.

RgDApa: 5' TGCGTGGCGTTGGGGGTCTC 3'

As reações de clivagem e as PCRs foram analisadas em gel de agarose a $1 \%$ e $2 \%$, respectivamente.

\subsubsection{Obtenção do fragmento gDVac1AA}

Após todas as seleções feitas, um clone pRE4Vac1AA foi selecionado para retirada do fragmento gDVac1AA para posterior clonagem no vetor pVAX. Como já foi dito anteriormente a gD está flanqueada pelo sítio de restrição HindIII, dessa forma, todo o fragmento gDVac1AA pode ser retirado do clone pRE4Vac1AA pela utilização dessa enzima. Assim, $3 \mu \mathrm{g}$ do vetor pRE4Vac1AA foi digerido utilizando-se 15 unidades da enzima HindIII, 
tampão React $2 \mathrm{em}$ um volume final de $60 \mu \mathrm{L}$, a $37^{\circ} \mathrm{C}$ por 16 horas. A clivagem foi analisada em gel de agarose a $1 \%$ e o fragmento gDVac1AA purificado utilizando-se o Wizard SV Gel and PCR Clean-Up System.

\subsubsection{Clonagem do fragmento gDVac1AA no vetor $\mathrm{pVAX}$}

O fragmento gDVac1AA, obtido como descrito no item anterior, foi clonado no plasmídeo pVAX clivado também com a enzima HindIII (item 4.1.2) pela reação de ligação, feita a $4^{\circ} \mathrm{C}$ por 16 horas, utilizando-se 150 ng do inserto gDVac1AA, 120ng do vetor $\mathrm{pVAX}$, tampão da enzima e 1 unidade da T4 DNA ligase em um volume final de $10 \mu \mathrm{L}$.

Metade do volume da ligação foi utilizada na transformação de células de $E$. coli Top10 competentes que foram plaqueadas em ágar LB contendo $50 \mu \mathrm{g} / \mathrm{mL}$ do antibiótico canamicina.

A seleção do plasmídeo recombinante pVAXgDVac1AA foi feita inicialmente realizando uma PCR de colônias em grupo (5 grupos de 5 colônias cada), para abranger um número maior de colônias, portanto, a suspensão de bactéria foi feita com várias colônias em $50 \mu \mathrm{L}$ de água. A PCR foi feita com o programa VAC (TM de $\left.50^{\circ} \mathrm{C}\right)$ em um volume final de $20 \mu \mathrm{L}$, utilizando-se $5 \mu \mathrm{L}$ da suspensão bacteriana como fonte de DNA, $0,1 \mu \mathrm{M}$ de cada oligonucleotídeo**, 0,2mM de cada dNTPs, tampão da enzima, 1,5mM de $\mathrm{MgCl}_{2}$ e 1 unidade da enzima Taq DNA polimerase.

**Para cada suspensão bacteriana foi realizado duas PCRs, uma utilizando os oligonucleotídeos $\mathrm{T} 7$ e RgDApa, que hibridizam no pVAX e dentro da gD próximo ao sítio ApaI, respectivamente, indicando a direção do fragmento gDVac1AA no interior do pVAX. A segunda reação foi realizada com os oligonucleotídeos T7 e BGH ambos anelam no pVAX, um sendo sense e o outro antisense, respectivamente. Dessa forma, foi possível verificar a quantidade de fragmentos gDVac1AA que se ligaram no interior do vetor. 
O produto das PCRs foi analisado em gel de agarose a 1\% e a partir dos resultados foi feito uma nova PCR de dois grupos que apresentaram fragmentos de amplificação do tamanho esperado. A reação foi semelhante a anterior, exceto pelos oligonucleotídeos utilizados, duas reações foram realizadas para cada um dos dois grupos: uma com T7/R2Apa(curto) e outra com F1Apa(curto)/BGH, que identificam a presença do fragmento Vac1AA e sua direção. Os primers T7 e BGH hibridizam no pVAX e os oligonucleotídeos R2Apa(curto) e F1Apa(curto) no fragmento Vac1AA. Além dos primers diferentes, a TM da reação foi de $50^{\circ} \mathrm{C}$ e a extensão de 2 minutos. Novamente os resultados foram analisados em gel de agarose a $1 \%$ e a partir dos resultados foi feito uma nova PCR das dez colônias pertencentes aos dois grupos separadamente e já com os plasmídeos extraídos.

A reação de PCR foi feita utilizando-se o programa VAC (TM de $50^{\circ} \mathrm{C}$ e extensão de 2 minutos) em um volume final de $20 \mu \mathrm{L}$, utilizando-se 50ng de cada plasmídeo extraído, $0,1 \mu \mathrm{M}$ de cada oligonucleotídeo**, $0,2 \mathrm{mM}$ de cada dNTPs, tampão da reação, $1,5 \mathrm{mM}$ de $\mathrm{MgCl}_{2}$ e 1 unidade da enzima Taq DNA polimerase. O produto da PCR foi analisado em gel de agarose a $1 \%$.

**Para cada plasmídeo foi realizado três PCRs, uma utilizando os oligonucleotídeos T7 e $\mathrm{BGH}$, que indica a quantidade de fragmentos gDVac1AA no interior do pVAX, outra com $\mathrm{T} 7$ e $\operatorname{RgDApa}$ que indica a direção do fragmento no interior do vetor e a última com T7 e R2Apa(curto) que indica a presença da Vac1AA e sua direção.

Além das PCRs, os plasmídeos extraídos das dez colônias também foram submetidos a reação de clivagem: 500ng de cada plasmídeo foram digeridos com 3 unidades das enzimas $P v u I I$ e NotI, tampão universal em uma reação final de $20 \mu \mathrm{L}$ a $37^{\circ} \mathrm{C}$ por 16 horas. A digestão foi analisada em gel de agarose a $1 \%$.

A partir dos resultados obtidos com as PCRs e a análise de restrição dois plasmídeos recombinantes $\mathrm{pVAXgDVac1AA}$ foram analisados por seqüenciamento utilizando-se os 
oligonucleotídeos T7, BGH e FgDApaseq para confirmação da seqüência e posteriormente um deles foi utilizado nos ensaios in vitro e in vivo.

FgDApaseq: 5' AGGGGGTGACGGTGGACAGC 3'

\section{$\underline{4.5}$ Construcão da vacina pVAXgDVac1PA}

\subsubsection{Obtenção do fragmento Vac1PA}

Após o seqüenciamento dos seis clones pGEMVac1AA (item 4.3), um clone pGEMVac1AA foi selecionado para ser utilizado como molde na construção do fragmento Vac1PA (denominado Vac1PA, pois apresenta o sítio da enzima PvuII e ApaI nas extremidades 5' e 3', respectivamente). Esse fragmento foi obtido por uma reação de amplificação utilizando-se o programa VAC com TM de $60^{\circ} \mathrm{C}$, composta de 80ng do molde pGEMVac1AA, 0,1 $\mathrm{M}$ de cada oligonucleotídeo [F1Pvu e R2Apa(curto)], 0,2mM de cada dNTPs, tampão da enzima, $1,5 \mathrm{mM}$ de $\mathrm{MgCl}_{2}$ e 5 unidades da enzima Taq DNA polimerase, em um volume final de $100 \mu \mathrm{L}$. O produto da PCR foi analisado em gel de agarose a $2 \%$ e o fragmento de interesse purificado utilizando-se o QIAquick PCR Purification Kit (Qiagen).

Em seguida, o fragmento Vac1PA $(1,6 \mu \mathrm{g})$ foi digerido com 10 unidades da enzima ApaI e 5 unidades da enzima $P v u I I$ utilizando-se o tampão B em um volume final de $40 \mu \mathrm{L}$, a $37^{\circ} \mathrm{C}$ por 5 horas. Como a clivagem de produtos de PCR elimina fragmentos muito pequenos, algumas bases no ínicio e fim do inserto a diferença de tamanho do fragmento não digerido e digerido não é possível de ser visualizada em gel de agarose por isso o fragmento clivado foi diretamente purificado utilizando-se o QIAquick PCR Purification Kit. 


\subsubsection{Construção do fragmento gDVac1PA}

\subsubsection{Clivagem do vetor pRE4}

O vetor pRE4 (Figura 1) $(4,8 \mu \mathrm{g})$ também foi digerido com 10 unidades das enzimas PvuII e ApaI juntamente com tampão B em uma reação de $50 \mu \mathrm{L}$, a $37^{\circ} \mathrm{C}$ por 16 horas para posterior clonagem do fragmento Vac1PA nesse plasmídeo. O vetor pRE4 após a digestão foi analisado em gel de agarose a $1 \%$ e purificado utilizando-se o Wizard SV Gel and PCR Clean-Up System.

\subsubsection{Construção do vetor pRE4Vac1PA}

O fragmento Vac1PA e o vetor pRE4 clivados com as enzimas PvuII e ApaI foram utilizados na seguinte reação de ligação: 100ng do vetor, 240ng do inserto, tampão da enzima e 1 unidade da T4 DNA ligase, em uma reação final de $10 \mu \mathrm{L}$, realizada a $4{ }^{\circ} \mathrm{C}$ por 16 horas.

Metade do volume da ligação foi utilizada na transformação de células de $E$. coli Top10 competentes que foram plaqueadas em ágar LB contendo $100 \mu \mathrm{g} / \mathrm{mL}$ do antibiótico ampicilina.

Plasmídeos de dez colônias da ligação entre pRE4 e Vac1PA foram extraídos e submetidos a PCR utilizando-se o programa VAC $\left(\mathrm{TM}\right.$ de $\left.50^{\circ} \mathrm{C}\right), 50$ ng de plasmídeo como molde, $0,1 \mu \mathrm{M}$ de cada oligonucleotídeo [FgDPvu e R2Apa(curto)**], 0,2mM de cada dNTPs, tampão da enzima, $1,5 \mathrm{mM}$ de $\mathrm{MgCl}_{2}$ e 1,5 unidades da enzima Taq DNA polimerase, em um volume final de $20 \mu \mathrm{L}$. O produto da PCR foi analisado em gel de agarose a $1 \%$.

\section{FgDPvu 5' GACCCCAATCGCTTTCGC 3'}

**O primer FgDPvu hibridiza no interior da gD próximo ao sitio PvuII e o R2Apa(curto) no final do fragmento Vac1PA, dessa forma é possível identificar a presença desse inserto e sua direção dentro da gD. 
Plasmídeos de outras sete colônias da ligação entre pRE4 e Vac1PA foram extraídos e submetidos, juntamente a dois clones positivos para a PCR, a reação de clivagem utilizandose 800ng de cada clone, 5 unidades das enzimas PvuII e ApaI, tampão B em um volume final de $30 \mu \mathrm{L}$, a $37^{\circ} \mathrm{C}$ por 16 horas, para verificação da presença do inserto Vac1PA. A reação foi analisada em gel de agarose a $1,5 \%$.

\subsubsection{Obtenção do fragmento gDVac1PA}

Três plasmídeos da ligação entre pRE4 e Vac1PA foram, por fim, submetidos a duas

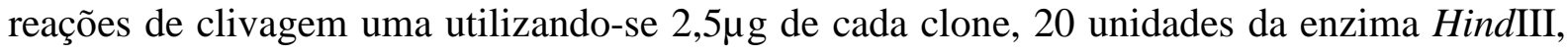
tampão React2, em um volume final de $60 \mu \mathrm{L}$ a $37^{\circ} \mathrm{C}$ por 16 horas. A outra foi feita com 500ng de cada clone, 5 unidades da enzima ApaI, tampão B, em um volume final de $20 \mu \mathrm{L}$, a $37^{\circ} \mathrm{C}$ por 16 horas. A clivagem com a enzima HindIII libera todo o fragmento gDVac1PA dos clones positivos, enquanto a enzima $A p a \mathrm{I}$ apenas lineariza o vetor o que nos fornece a possibilidade de avaliar se o plasmideo é recombinante pelo tamanho do fragmento gerado. As reações foram analisadas em gel de agarose a $1 \%$.

Após todas essas seleções realizadas, um clone pRE4Vac1PA foi selecionado para recuperarmos o fragmento gDVac1PA que foi digerido com a enzima HindIII da forma acima mencionada e purificado utilizando-se o Wizard SV Gel and PCR Clean-Up System.

\subsubsection{Clonagem do fragmento gDVac1PA no vetor pVAX}

O pVAX (Figura 2) foi digerido com a enzima HindIII como descrito no item 4.1.2 e foi utilizado na construção da vacina pVAXgDVac1PA.

O fragmento gDVac1PA foi clonado no plasmídeo pVAX pela reação de ligação, feita a $4^{\circ} \mathrm{C}$ por 16 horas, utilizando-se 120 ng do inserto gDVac1PA, 120ng do vetor pVAX, tampão da enzima e 2 unidade da T4 DNA ligase, em um volume final de $15 \mu \mathrm{L}$. 
Metade do volume da ligação foi utilizada na transformação de células de $E$. coli Top10 competentes que foram plaqueadas em ágar LB contendo $50 \mu \mathrm{g} / \mathrm{mL}$ do antibiótico canamicina.

A seleção do plasmídeo recombinante pVAXgDVac1PA foi feita inicialmente realizando uma PCR de colônias em grupo (5 grupos de 5 colônias cada), como explicado anteriormente (itens 4.1.3 e 4.4.3), utilizando-se o programa VAC (TM de $50^{\circ} \mathrm{C}$ ) em um volume final de $20 \mu \mathrm{L}$, utilizando-se $5 \mu \mathrm{L}$ da suspensão bacteriana, $0,1 \mu \mathrm{M}$ de cada oligonucleotídeo**, 0,2mM de cada dNTPs, tampão da enzima, 1,5mM de $\mathrm{MgCl}_{2}$ e 1 unidade da enzima Taq DNA polimerase.

**Para cada susupensão bacteriana foi realizado duas PCRs, uma utilizando os oligonucleotídeos T7 e RgDApa, que indica a direção do fragmento no interior do vetor pVAX e, a segunda, realizada com os oligonucleotídeos T7 e BGH, que indicam a quantidade de fragmentos gDVac1PA que se ligaram no interior do vetor.

O produto das PCRs foi analisado em gel de agarose a 1\% e a partir dos resultados foi feito uma nova PCR de quatro grupos que apresentaram fragmentos de amplificação do tamanho esperado. A reação foi semelhante a anterior, exceto pelos oligonucleotídeos utilizados, duas reações foram realizadas para cada um dos quatro grupos: T7/R2Apa(curto) e FgDPvu/BGH que identificam a presença do fragmento Vac1PA e sua direção e do fragmento gDVac1PA e sua direção, respectivamente. Como já mencionado anteriormente os primers T7 e BGH hibridizam no interior do pVAX, R2Apa(curto), no final do fragmento Vac1PA e FgDPvu, na gD, próximo ao sitio PvuII onde foi clonado o inserto Vac1PA. Além dos primers diferentes a TM da reação foi de $50^{\circ} \mathrm{C}$ e a extensão de 2 minutos. Novamente os resultados foram analisados em gel de agarose a $1 \%$ e a partir dos resultados foi feito uma nova PCR de dez colônias separadamente pertencentes a dois grupos e já com os plasmídeos extraídos. 
A reação de PCR foi feita utilizando-se o programa VAC (TM de $50^{\circ} \mathrm{C}$ e extensão de 2 minutos) em um volume final de $20 \mu \mathrm{L}$, utilizando-se 50ng de cada plasmídeo extraído, $0,1 \mu \mathrm{M}$ de cada oligonucleotídeo**, $0,2 \mathrm{mM}$ de cada dNTPs, tampão da enzima, 1,5mM de $\mathrm{MgCl}_{2}$ e 1 unidade da enzima Taq DNA polimerase. O produto da PCR foi analisado em gel de agarose a $1 \%$.

**Para cada plasmídeo foi realizado três PCRs, uma utilizando os oligonucleotídeos T7 e $\mathrm{BGH}$, que indica a quantidade de fragmentos gDVac1PA no interior do pVAX, outra com $\mathrm{T} 7$ e RgDApa que indica a direção do fragmento no interior do vetor e a última com T7 e R2Apa(curto) que indica a presença da Vac1PA e sua direção.

Além das PCRs, os plasmídeos extraídos das dez colônias também foram submetidos a reação de clivagem: 500ng de cada plasmídeo foram digeridos com 3 unidades das enzimas $P v u \mathrm{II}$ e $N o t \mathrm{I}$, tampão universal, em uma reação final de $20 \mu \mathrm{L}$, a $37^{\circ} \mathrm{C}$ por 16 horas. A digestão foi analisada em gel de agarose a $1 \%$.

A partir dos resultados obtidos com as PCRs e a análise de restrição dois plasmídeos recombinantes pVAXgDVac1PA foram analisados por seqüenciamento utilizando-se os oligonucleotídeos T7, BGH e FgDPvuseq para confirmação da seqüência e posteriormente um deles foi utilizado nos ensaios in vitro e in vivo.

FgDPvuseq 5' ATTTTGTTTGTCGTCATAG 3'

\subsection{Construcão da vacina pVAXgDVac2}

\subsubsection{Obtenção do fragmento Vac2}

Após o seqüenciamento dos seis clones pGEMVac1AA (item 4.3) um clone pGEMVac1AA foi selecionado para ser utilizado como molde na construção do fragmento Vac2 (seqüência dos cinco epitopos em duplicata com o sítio da ezima ApaI nas extremidades 
5' e 3') (Tabela 3-Delineamento Experimental). Inicialmente foi realizada duas reações de amplificação utilizando-se o programa VAC, ambas composta de 50ng do molde pGEMVac1AA, 0,1 $\mu \mathrm{M}$ de cada oligonucleotídeo**, $0,2 \mathrm{mM}$ de cada dNTPs, tampão da reação, $1,5 \mathrm{mM}$ de $\mathrm{MgCl}_{2}$ e 5 unidades da enzima Taq DNA polimerase, em um volume final de $100 \mu \mathrm{L}$. Os produtos das PCRs foram analisados em gel de agarose a $1 \%$ e os fragmentos purificados utilizando-se o QIAquick PCR Purification Kit.

**Uma reação foi realizada com os oligonucleotideos F1Apa(curto) e R2Bam inserindo no início do fragmento o sítio da enzima ApaI (sítio em destaque na seqüência dos primers) e no final o sítio da enzima BamHI (sítio em destaque na seqüência dos primers) gerando o fragmento Vac1AB; a segunda com os oligonucleotídeos R2Apa(curto) e F1Bam inserindo os sítios de forma contrária, BamHI no início e ApaI no final gerando o fragmento Vac1BA, dessa forma, é possível ligar esses dois fragmentos pelo sítio de BamHI criando a Vac2 que posteriormente é digerida com ApaI para clonagem no vetor pRE4 clivado com a mesma enzima.

F1Apa(curto) 5’A GGGCCCCTGGAAGACCCCTACGAG 3'(já descrito anteriormente) R2Bam 5'GCGGATCCCACGTTGCGAAGTCCTTCC 3'

F1Bam 5'CGGGATCCCTGGAAGACCCCTACGAG 3'

R2Apa(curto) 5’ATGGGCCCCACGTTGCGAAG 3' (já descrito anteriormente)

Em seguida, os fragmentos Vac1AB e Vac1BA $(3 \mu \mathrm{g})$ foram digeridos separadamente com 30 unidades da enzima BamHI (Invitrogen) utilizando-se o tampão React3, em um volume final de $80 \mu \mathrm{L}$, a $37^{\circ} \mathrm{C}$ por 16 horas e diretamente purificados utilizando-se o QIAquick PCR Purification Kit.

Após a digestão os fragmentos foram submetidos a seguinte reação de ligação: 900ng de cada fragmento, Vac1AB e Vac1BA, incubados com tampão da enzima e 6 unidade da T4 DNA ligase em um volume final de $90 \mu \mathrm{L}$, feita a $4{ }^{\circ} \mathrm{C}$ por 16 horas. A ligação foi analisada 
em gel de agarose a $1 \%$ e o fragmento Vac2 purificado utilizando-se o Purelink ${ }^{\mathrm{TM}}$ Quick Gel Extraction Kit (Invitrogen).

Tendo montado a Vac2 o próximo passo foi digerir esse fragmento com a enzima ApaI para posterior clonagem no vetor pRE4 e consequentemente união com a gD. A Vac2 $(1,2 \mu \mathrm{g})$ foi clivada com 20 unidades da enzima ApaI, juntamente com o tampão B, a $37^{\circ} \mathrm{C}$ por 16 horas e, então, purificada utilizando-se o QIAquick PCR Purification Kit.

\subsubsection{Construção do fragmento gDVac2}

\subsubsection{Construção do vetor pRE4Vac2}

O fragmento Vac2 e o vetor pRE4 (Figura 1) (clivagem descrita no item 4.4.2.1) clivados com a enzima ApaI foram utilizados na seguinte reação de ligação: 100ng do vetor, 240ng do inserto, tampão da enzima e 1,5 unidades da T4 DNA ligase, em uma reação final de $20 \mu \mathrm{L}$ realizada a $4^{\circ} \mathrm{C}$ por 16 horas.

Metade do volume da ligação foi utilizada na transformação de células de E. coli Top10 competentes que foram plaqueadas em ágar LB contendo $100 \mu \mathrm{g} / \mathrm{mL}$ do antibiótico ampicilina.

Quinze colônias da ligação entre pRE4 e Vac2 foram submetidas a PCR, utilizando-se o programa VAC (TM de 55 $5^{\circ}$ ) (PCR de colônia, descrito no item 4.1.3), $5 \mu 1$ da suspenção bacteriana, $0,1 \mu \mathrm{M}$ de cada oligonucleotídeo**, $0,2 \mathrm{mM}$ de cada dNTPs, tampão da enzima, 1,5mM de $\mathrm{MgCl}_{2}$ e 1 unidade da enzima Taq DNA polimerase, em um volume final de $20 \mu \mathrm{L}$. O produto da PCR foi analisado em gel de agarose a $1 \%$.

**Para cada plasmídeo foi realizado duas PCRs (assim como descrito anteriormente para o fragmento Vac1AA), uma utilizando os oligonucleotídeos FgDApa e R2Apa(curto), que indica a direção do inserto Vac2 no interior da gD; a segunda reação foi realizada com os 
oligonucleotídeos FgDApa e RgDApa que indicam a quantidade de fragmentos Vac2 que se ligaram no interior da $\mathrm{gD}$.

A partir dos resultados obtidos com as PCRs, os plasmídeos de dez das quinze colônias foram extraídos e submetidos a reação de clivagem: 800ng de cada plasmídeo separadamente foram digeridos com 5 unidades da enzima ApaI juntamente com tampão B, em um volume final de $20 \mu \mathrm{L}$, a $37^{\circ} \mathrm{C}$ por 16 horas. A digestão foi analisada em gel de agarose a $1 \%$.

\subsubsection{Obtenção do fragmento gDVac2}

Após as seleções acima realizadas, um clone pRE4Vac2 foi selecionado para retirada do fragmento gDVac2 por meio da reação de clivagem: $4 \mu \mathrm{g}$ do vetor pRE4Vac2, foi digerido com 35 unidades da enzima HindIII, tampão React2, em um volume final de $80 \mu \mathrm{L}$, a $37^{\circ} \mathrm{C}$ por 16 horas. A reação foi analisada em gel de agarose a $1 \%$ e o fragmento purificado utilizando-se o Purelink ${ }^{\mathrm{TM}}$ Quick Gel Extraction Kit.

\subsubsection{Clonagem do fragmento gDVac2 no vetor $\mathrm{pVAX}$}

O pVAX (Figura 2) foi digerido com a enzima HindIII como descrito no item 4.1.2 e foi utilizado na construção da vacina pVAXgDVac2.

$\mathrm{O}$ fragmento gDVac2 foi clonado no plasmídeo $\mathrm{pVAX}$ pela reação de ligação, feita a $4^{\circ} \mathrm{C}$ por 16 horas, utilizando-se $180 \mathrm{ng}$ do inserto gDVac2, $120 \mathrm{ng}$ do vetor $\mathrm{pVAX}$, tampão da enzima e 1,5 unidades da T4 DNA ligase, em um volume final de $15 \mu \mathrm{L}$.

Metade do volume da ligação foi utilizada na transformação de células de E. coli Top 10 competentes que foram plaqueadas em ágar $\mathrm{LB}$ contendo $50 \mu \mathrm{g} / \mathrm{mL}$ do antibiótico canamicina.

A seleção do plasmídeo recombinante pVAXgDVac2 foi feita inicialmente realizando uma PCR de 10 colônias, como explicado anteriormente (item 4.1.3), utilizando-se o 
programa VAC (TM de $50^{\circ} \mathrm{C}$ e extensão de 2 minutos), $5 \mu l$ da suspensão bacteriana, $0,1 \mu \mathrm{M}$ de cada oligonucleotídeo**, 0,2mM de cada dNTPs, tampão da enzima, 1,5mM de $\mathrm{MgCl}_{2}$ e 1 unidade da enzima Taq DNA polimerase, em um volume final de $20 \mu \mathrm{L}$.

**Para cada plasmídeo foi realizado três PCRs, uma utilizando os oligonucleotídeos T7 e $\mathrm{BGH}$, que indica a quantidade de fragmentos gDVac2 no interior do pVAX, outra com $\mathrm{T} 7 \mathrm{e}$ RgDApa que indica a direção do fragmento no interior do vetor e a última com T7 e R2Apa(curto) que indica a presença da Vac2 e sua direção. O produto das PCRs foi analisado em gel de agarose a $1 \%$.

A partir dos resultados obtidos com as PCRs, os plasmídeos de duas das dez colônias submetidas a PCR foram extraídos e submetidos a duas reações de clivagem, uma com 500ng de cada plasmídeo digerido com 5 unidades da enzima BamHI** e tampão React2 e a outra com 500ng de cada plasmídeo com 5 unidades da enzima HindIII e tampão React2, ambas em uma reação final de $20 \mu \mathrm{L}$, a $37^{\circ} \mathrm{C}$ por 16 horas. As digestões foram analisadas em gel de agarose a $1 \%$.

**A enzima BamHI digere no sítio presente no meio do fragmento Vac2 e no vetor pVAX podendo indicar a presença do fragmento Vac2 e sua direção.

A partir dos resultados obtidos com a PCR e a análise de restrição, dois plasmídeos recombinantes $\mathrm{pVAXgDVac2}$ foram analisados por seqüenciamento, utilizando-se os oligonucleotídeos T7, BGH e FgDApaseq para confirmação da seqüência e, posteriormente, um deles foi utilizado nos ensaios in vitro e in vivo. 


\subsection{Purificacão das construcões vacinais}

\subsubsection{Extração e purificação das construções de DNA}

Os plasmídeos pVAXgD, pVAXgDVac1AA, pVAXgDVac1PA e pVAXgDVac2 foram purificados por cromatografia de troca iônica, utilizando-se o kit comercial Qiagen Giga Plasmid Purification, EndoFree (Qiagen).

Bactérias E. coli DH-5 $\alpha$ (ou Top 10) foram transformadas com cada plasmídeo e plaqueadas em ágar LB juntamente com o antibiótico canamicina na concentração de $50 \mu \mathrm{g} / \mathrm{mL}$. Após a transformação, escolheu-se uma colônia que foi inoculada em $5 \mathrm{~mL}$ de caldo LB (USB) contendo canamicina a $50 \mu \mathrm{g} / \mathrm{mL}$, sendo o meio incubado por 8 horas, a 200rpm, $37^{\circ} \mathrm{C}$ (Incubador shaker innova 44, New Brunswick). Em seguida, essa cultura foi diluída 1/1000 em 2,5 litros de caldo LB, contendo canamicina a 50 $\mu \mathrm{g} / \mathrm{mL}$, sendo incubada novamente a $37^{\circ} \mathrm{C}, 200 \mathrm{rpm}$, durante 16 horas. Após esse período, o material foi centrifugado a $6650 \mathrm{~g}$ por 15 minutos a $4^{\circ} \mathrm{C}$ (Beckman $\left.\mathrm{J} 2-\mathrm{HS}\right)$, o sobrenadante desprezado e cerca de 7 gramas do sedimento foi ressuspendido em 125mL de tampão P1 (Tris- $\mathrm{HCl}$ a 50mM, pH 8,0, EDTA a $10 \mathrm{mM}$ e RNAse a $100 \mu \mathrm{g} / \mathrm{mL}$ ). Em seguida, foram adicionados $125 \mathrm{~mL}$ de tampão P2 $(\mathrm{NaOH}$ a $200 \mathrm{mM}$ e SDS a $1 \%)$ e após incubação de 5 minutos, adicionou-se $125 \mathrm{~mL}$ do tampão P3 (acetato de potássio a 3,0M, pH 5,5). O material foi filtrado e mantido no gelo por 30 minutos após adição de tampão para remoção de endotoxinas.

O filtrado foi aplicado em uma coluna Qiagen com resina de troca iônica previamente equilibrada com tampão QBT $(\mathrm{NaCl}$ a $750 \mathrm{mM}$, MOPS a 50mM, pH 7,0, etanol a $15 \%$ e Triton X-100 a 0,15\%). Após a aplicação do filtrado, a resina foi lavada com $600 \mathrm{~mL}$ de tampão QC ( $\mathrm{NaCl}$ a 1,0M, MOPS a 50mM, pH 7,0 e etanol a $15 \%)$ e o DNA plasmideal foi eluído com 100mL de tampão QN ( $\mathrm{NaCl}$ a 1,25M, MOPS a 50mM, pH 7,0 e etanol a 15\%). O DNA eluído foi precipitado com isopropanol absoluto, centrifugado a 26904g, por 45 minutos 
a $4^{\circ} \mathrm{C}$, lavado com etanol a $70 \%$ e centrifugado novamente nas mesmas condições. Por fim o sedimento foi ressuspendido em cerca de $1,0 \mathrm{~mL}$ de água estéril livre de endotoxinas.

\subsubsection{Quantificação, avaliação da integridade e pureza dos plasmídeos purificados}

Após a purificação das diferentes construções vacinais, foi realizada a quantificação, a avaliação da integridade e a pureza dos produtos purificados. A quantificação dos plasmídeos foi realizada em espectrofotômetro nos comprimentos de onda de 260 a 280nm, utilizando-se o aparelho GeneQuant II ${ }^{\mathrm{TM}}$ (Amershan-Pharmacia, BioSciences).

A caracterização dos plasmídeos pVAXgD, pVAXgDVac1AA, pVAXgDVac1PA e pVAXgDVac2 foram realizadas com a enzima HindIII. Aproximadamente $1 \mu \mathrm{g}$ de cada plasmídeo separadamente foi incubado com 5 unidades da enzima HindIII, tampão React2, em $20 \mu \mathrm{L}$ finais, a $37^{\circ} \mathrm{C}$ por 16 horas. Em seguida, o produto da digestão de cada amostra, bem como os plasmídeos não digeridos, foram submetidos a eletroforese em gel de agarose a $1 \%$.

A pureza foi realizada pela determinação da presença de endotoxinas bacterianas nas vacinas purificadas pelo kit Qiagen Giga Plasmid Purification, EndoFree. A avaliação é realizada por meio do teste cromogênico do lisado de amebócito de Limulus polyphemus (LAL), que é um teste quantitativo para avaliação de endotoxinas de bactérias Gram-negativas utilizando o QCL-100 LAL kit (Cambrex).

\section{$\underline{4.8}$ Expressão e Purificacão das proteínas Vac1 e Vac2}

As proteínas Vac1 e Vac2 foram expressas em sistema procarioto utilizando-se E. coli e purificadas por cromatografia de afinidade, como será descrito em seguida. As sequiências que codificam a proteína Vac1 (5 epitopos da proteína Hsp65) e a Vac2 (5 epitopos em duplicata) foram clonadas no vetor pET29b (Novagen) pelo grupo da Profa. Ana Paula Ulian 
de Araújo (Instituto de Física de São Carlos - USP), originando os vetores pET29bVac1 e pET29bVac2, que foram utilizados para expressão das proteínas.

\subsubsection{Expressão das proteínas Vac1 e Vac2}

As construções pET29bVac1 e pET29bVac2 foram utilizadas na transformação de células competentes E. coli BL21 (DE3) (Invitrogen) utilizadas na expressão das proteínas Vac1 e Vac2. Uma colônia de células E. coli BL21(DE3) transformada com pET29bVac1 e uma transformada com pET29bVac2 foram separadamente coletadas e inoculadas, cada uma, em um pré-inóculo de 10mL de caldo LB adicionado de antibiótico canamicina, para o qual o vetor pET apresenta gene de resistência. Para ambas as construções os procedimentos descritos na expressão e purificação foram os mesmos. O pré-inoculo foi incubado sob agitação de $200 \mathrm{rpm}$, a $37^{\circ} \mathrm{C}$ por 16 horas e, em seguida, diluído 1:125 em caldo LB suplementado com canamicina. As células foram crescidas nas mesmas condições até uma densidade óptica (DO) de aproximadamente 0,6 (fase logarítmica do crescimento), em uma absorbância de 600nm medida em espectofotômetro UV-1650PC (UV-Visible Spectrophotometer-Shimadzu). As bactérias foram induzidas com 0,2mM de IPTG (Invitrogen), a $37^{\circ} \mathrm{C}$ por 3, 4 e 16 horas, sob agitação de 200rpm, para a expressão da proteína recombinante de interesse. Amostras de $1 \mathrm{~mL}$ foram retiradas antes e após a indução. Esse material foi centrifugado 2 minutos a 1000g em uma centrifuga 5402 (Eppendorf), sendo o sobrenadante descartado e a parte celular armazenada para análise em SDS-PAGE a 13,5\% (Eletroforese desnaturante em gel de poliacrilamida contendo duodecil sulfato de sódio) (Laemmli, 1970).

Após a indução por 4h (melhor tempo de expressão), a cultura foi recolhida em frascos apropriados e centrifugada 12 minutos, $6650 \mathrm{~g}$ a $4^{\circ} \mathrm{C} . \mathrm{O}$ sobrenadante (meio de cultura) foi descartado e as células ressuspendidas em $15 \mathrm{~mL}$ de tampão de sonicação, pH 7,2. Inicialmente as células foram ressuspendidas em tampão de sonicação sem agente 
desnaturante $\left(150 \mathrm{mM}\right.$ de $\mathrm{NaCl}, 20 \mathrm{mM}$ de $\mathrm{Na}_{2} \mathrm{HPO}_{4}$ e $50 \mathrm{mM}$ de imidazol), incubadas 30 minutos no gelo e, em seguida, submetida a sonicação alternada - 6 repetições de 1 minuto com intervalo de 30 segundos - em um sonicador Vibra cell ${ }^{\mathrm{TM}}$ (Sonic \& Materials Inc.). O lisado foi centrifugado por 25 minutos a $4^{\circ} \mathrm{C}, 26904 \mathrm{~g}$ e o sobrenadante e precipitado foram separados. Frações dos sobrenadantes e do sedimento foram analisadas em SDS-PAGE para testes da solubilidade da proteína. Após essa análise foi realizado um novo protocolo ressuspendendo as células em tampão de sonicação com agente desnaturante $(150 \mathrm{mM}$ de $\mathrm{NaCl}, 20 \mathrm{mM}$ de $\mathrm{Na}_{2} \mathrm{HPO}_{4}, 50 \mathrm{mM}$ de imidazol e $5 \mathrm{M}$ de uréia), acrescido de $12,5 \mathrm{mg}$ de lisozima (Sigma), seguindo o mesmo protocolo acima. No entanto, após a sonicação, a suspenção foi centrifugada por 25 minutos a $4^{\circ} \mathrm{C}, 26904 \mathrm{~g}$, e, em seguida, o sobrenadante foi armazenado a $4^{\circ} \mathrm{C}$ e o precipitado submetido novamente a sonicação (o procedimento de sonicação foi realizado três vezes, na primeira vez foi realizado com o sedimento celular e nas outras duas com o precipitado formado após a sonicação anterior) para solubilização completa da proteína. Frações dos sobrenadantes e do sedimento foram analisadas em SDS-PAGE para testes da solubilidade da proteína.

A análise em SDS-PAGE foi feita utilizando-se as amostras da cultura não induzida, induzida, sobrenadantes após a lise e uma pequena parte do sedimento de lise nos quais foram adicionados água e tampão da amostra 5 vezes concentrado (Tris-HCl a 200mM, pH 6,8, SDS a $360 \mathrm{mM}$, glicerol a $41,6 \%$, azul de bromofenol a $0,05 \%$ e 2 -mercaptoetanol a $12,5 \%$ ), todas as amostras foram fervidas por 5 minutos e aplicadas no gel $(20 \mu \mathrm{L})$ (Tampão de corrida-Trisbase a $125 \mathrm{mM}$, glicina a $960 \mathrm{mM}$ e SDS a $170 \mathrm{mM}, \mathrm{pH} 8,3)$, a eletroforese foi realizada po 2 horas a 100V.

\subsubsection{Purificação das proteínas Vac1 e Vac2}

A purificação das proteínas Vac1 e Vac2 foi realizada por cromatografia de afinidade, utilizando-se o aparelho Äkta Purifier (GE HealthCare), a coluna HiTrap Chelating HP5mL 
(GE HealthCare) e o reagente níquel.

Antes da purificação a resina foi lavada com 10 volumes de coluna (VC) de água, tratada com $6 \mathrm{VC}$ de $\mathrm{NaOH}$ a $1 \mathrm{M}$ e mantida em repouso por 30 minutos (o $\mathrm{NaOH}$ é utilizado para retirada de lipopolissacarídeo - LPS). Após esse intervalo de tempo, a resina foi lavada novamente com 10VC de água e imobilizada com $1 \mathrm{VC}$ de sulfato de níquel a $0,1 \mathrm{M}$.

Inicialmente a coluna foi equilibrada com 5VC de tampão de lavagem, $\mathrm{pH}$ 7,2 (150mM de $\mathrm{NaCl}, 20 \mathrm{mM}$ de $\mathrm{Na}_{2} \mathrm{HPO}_{4}, 20 \mathrm{mM}$ de $\mathrm{NaH}_{2} \mathrm{PO}_{4}, 5 \mathrm{M}$ de uréia e $50 \mathrm{mM}$ de imidazol). Em seguida, 50mL de sobrenadante, contendo $60 \mathrm{mg}$ de proteínas bacterianas, foram aplicados na coluna (diluído no tampão de lavagem), sendo a coluna lavada posteriormente com $10 \mathrm{~V}$ de tampão de lavagem. Proteínas contendo tag de histidina foram eluídas com imidazol na concentração de 50, 150, 250 e 500mM em tampão de lavagem. Todas as frações eluídas foram coletadas durante a purificação e submetidas a eletroforese. As frações recuperadas após a passagem do sobrenadante e da lavagem foram chamadas eluato e lavagem e as obtidas após a passagem do gradiente de imidazol foram nomeadas pela concentração de imidazol.

Separou-se $20 \mu \mathrm{L}$ de cada fração onde foi adicionado $5 \mu \mathrm{L}$ de tampão da amostra 5 vezes concentrado, sendo a mistura fervida por 5 minutos e analisadas em SDS-PAGE (apenas $20 \mu \mathrm{L}$ foi aplicado no gel).

As frações contendo a proteína de interesse foram dialisadas contra PBS (137mM de $\mathrm{NaCl}, 2,7 \mathrm{mM}$ de $\mathrm{KCl}, 8,1 \mathrm{mM}$ de $\mathrm{Na}_{2} \mathrm{HPO}_{4}$ e $1,5 \mathrm{mM}$ de $\mathrm{KH}_{2} \mathrm{PO}_{4}, \mathrm{pH}$ 7,2) utilizando-se a membrana Snake Skin ${ }^{\circledR}$ Pleated Dialysis Tubing 3500MWCO (PIERCE-PERBIO) para retirada do imidazol e da uréia. Essas frações foram colocadas dentro da membrana que ficou mergulhada em um litro de PBS por 24 horas a $4^{\circ} \mathrm{C}$ (PBS trocado 4 vezes). Após a diálise as proteínas foram quantificadas pelo ensaio de Bradford (Bradford, 1976), utilizando-se o corante Coomassie Plus ${ }^{\mathrm{TM}}$ Protein Assay Reagent (Pierce) e a leitura feita em 
espectrofotômetro de placa ( $\mu$ Quant Bio-Tek Instruments Inc.). A pureza foi determinada pela presença de endotoxinas bacterianas utilizando-se o teste cromogênico do lisado de amebócito de Limulus polyphemus (LAL).

OBS.: Todo material utilizado na purificação das proteínas eram livres de LPS (Endofree).

\subsection{Producão de anticorpos policlonais contra as proteínas Vac1 e Vac2}

As proteínas recombinantes Vac1 e Vac2 foram utilizadas na imunização de camundongos BALB/c para a produção de anticorpos policlonais anti-Vac1 e anti-Vac2. Para isso, camundongos isogênicos da linhagem BALB/c (fêmeas), com 7-8 semanas de idade, provenientes do Biotério de Animais Isogênicos da Faculdade de Medicina de Ribeirão PretoUSP, foram utilizados nos ensaios de imunização, segundo os princípios éticos adotado pelo Colégio Brasileiro de Experimentação Animal (COBEA) e condições estabelecidas pelo nosso grupo. Os animais foram mantidos em isoladores de animais, com temperatura, umidade, fluxo de ar e ciclo de luz claro/escuro controlado, com livre acesso a água e ração.

Os animais $(n=3)$ receberam as proteínas por via subcutânea em regime vacinal de 3

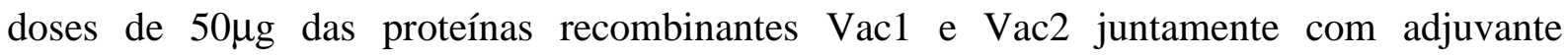
incompleto de Freud (AIF) (Gibco BRL) obedecendo um intervalo de 2 semanas entre cada dose e coleta do soro 20 dias após a última dose. O AIF foi preparado, de acordo com as instruções do fabricante, homogeneizando-se a proteína diluída em salina (Cloreto de sódio 0,9\% - Samtec Biotecnologia) e o adjuvante numa proporção de 1:1 (volume) até a aquisição de uma emulsão homogênea e consistente.

Após 20 dias da última imunização os animais foram sacrificados com o anestésico Ketamina (Agenner), na concentração de $100 \mathrm{mg} / \mathrm{Kg}$ de massa corpórea, por via endovenosa. Em seguida, foi realizada uma punção cardíaca para retirada do sangue do animal. O sangue 
foi incubado por 1 hora a temperatura ambiente e centrifugado por 10 minutos a 216g. Após centifugação o soro foi coletado e armazenado a $-20^{\circ} \mathrm{C}$.

Grupos e delineamento experimental: Grupo 1: $50 \mu \mathrm{g}$ de Vac1 + AIF

Grupo 2: $50 \mu \mathrm{g}$ de Vac2 + AIF

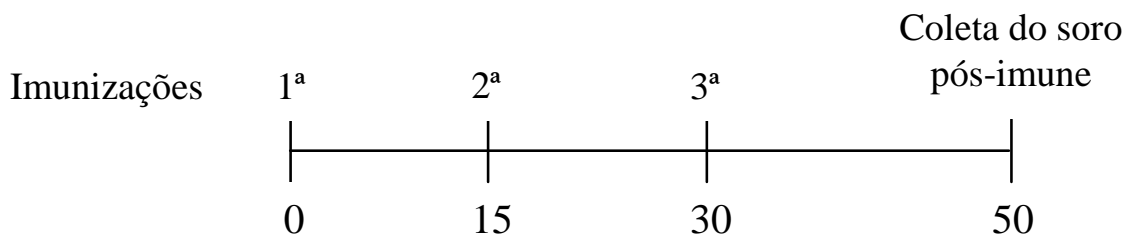

\subsubsection{Caracterização dos anticorpos policlonais anti-Vac1 e anti-Vac2}

A caracterização dos anticorpos anti-Vac1 e anti-Vac2 presente nos soros dos animais imunizados com as proteínas Vac1 e Vac2, respectivamente, foi realizada para detectar se esses anticorpos reagiam cruzadamente com a proteína Hsp60 de mamíferos.

Para isso células HEK293 (Human Embrionic Kidney) foram plaqueadas (1×10 células/poço) em placas de 24 poços (Corning), utilizando-se DMEM (Gibco), 10\% de SBF (Soro Bovino Fetal) (Gibco), 1\% de estreptomicina/penicilina (100unidades/mL de penicilina e $100 \mu \mathrm{g} / \mathrm{mL}$ de estreptomicina) (Gibco) (DMEM-C) e incubadas a $37^{\circ} \mathrm{C}$, em estufa umidificada contendo $5 \% \mathrm{CO}_{2}$ (TS Auto Flow $\mathrm{CO}_{2}$ Water Jacketed Incubator) por 2 horas para aderência das células, em seguida, foram mantidas a $37^{\circ} \mathrm{C}$ ou $42^{\circ} \mathrm{C}$ por 5 horas. Após esse período, foi retirado o meio de cultura das células, elas foram lavadas 2 vezes com PBS e foi adicionado $50 \mu \mathrm{L}$ de tampão de lise RIPA (Tris a 50mM, pH 8,0, $\mathrm{NaCl}$ a $150 \mathrm{mM}$, SDS a 0,1\%, IgePal 1\%, desoxiglicolato de sódio $0,5 \%$, coquetel de inibidores-Complete, EDTA free-Roche). As células foram lisadas, coletadas e incubadas no gelo por 10 minutos, em seguida, foram centrifugadas por 10 minutos a $1000 \mathrm{~g}, 4^{\circ} \mathrm{C}$ e separado sedimento e sobrenadante. 
O sedimento acrescido de $20 \mu \mathrm{L}$ de água, $20 \mu \mathrm{L}$ do meio de cultura retirado das células e $20 \mu \mathrm{L}$ do sobrenadante foram acrescidos de $5 \mu \mathrm{L}$ de tampão da amostra 5 vezes concentrado, fervidos por 5 minutos e submetidas a eletroforese em gel a $10 \%$, por 20 minutos a $50 \mathrm{~V}$ e, em seguida, 1,5 hora a $100 \mathrm{~V}$.

Após a eletroforese as proteínas foram transferidas para uma membrana de nitocelulose (Life Technologies) por 1,5 hora a 100V (Tampão de transferência-Tris-base a $22,7 \mathrm{mM}$, glicina a $61 \mathrm{mM}$, metanol a $18,3 \%, \mathrm{pH} 8,3$ ). A membrana foi incubada com tampão de bloqueio (PBS, 2\% de BSA-Albumina Bovina [INLAB], 0,05\% de Tween 20) por 2 horas a temperatura ambiente, lavada (PBS, 0,05\% de Tween 20 - PBS-T) e incubada com os anticorpos anti-Hsp60 (Clone Mab 11-13-Imgenex) (diluição 1:10000 em tampão bloqueio), anti-Vac1 policlonal ou anti-Vac2 policlonal (diluição 1:1000), a $4^{\circ} \mathrm{C}$ por 16 horas. A membrana foi, então, novamente lavada e incubada com o anticorpo de cabra contra IgG de camundongo marcado com peroxidase (Molecular Probes), diluído 1:5000, por 1 hora a temperatura ambiente. A revelação foi feita com peróxido de hidrogênio e DAB (Vector Peroxydase Substrate Kit).

\subsection{Caracterização in vitro das vacinas de DNA construídas}

\subsubsection{Transfecção de células in vitro com as vacinas construídas}

Para detecção da transcrição e tradução das proteínas codificadas pelas vacinas de DNA construídas, células eucarióticas HEK293 foram transfectadas pela utilização de cloreto de cálcio com as diferentes construções vacinais, pVAXgD, pVAXgDVac1AA, pVAXgDVac1PA e pVAXgDVac2.

Aproximadamente $1 \times 10^{5}$ células ressuspendidas em DMEM-C foram adicionadas a placas de 24 poços e incubadas por 16 horas a $37^{\circ} \mathrm{C}, 5 \%$ de $\mathrm{CO}_{2}$. Duas horas antes da 
transfecção o meio foi trocado por DMEM contendo $5 \%$ de SBF e $1 \%$ de estreptomicina/penicilina. A transfecção foi realizada pela adição em cada poço de 480ng de DNA, $54 \mu \mathrm{L}$ de água estéril, $6 \mu \mathrm{L}$ de cloreto de cálcio a 2,5M estéril e $60 \mu \mathrm{L}$ de HEBS $2 \mathrm{X}$ ( $\mathrm{NaCl}$ a $0,28 \mathrm{M}$, Hepes a $0,05 \mathrm{M}$ e $\mathrm{Na}_{2} \mathrm{HPO}_{4}$ a $1,5 \mathrm{mM}, \mathrm{pH} 7,05$ ) segundo o seguinte protocolo (para cada poço): em um tubo de $1,5 \mathrm{~mL}$ foram adicionados a água e o DNA e homogeneizado, em seguida, o $\mathrm{CaCl}_{2}$ a $2,5 \mathrm{M}$ foi adicionado a mistura de água e DNA e realizada nova homogeneização; em um outro tubo de $1,5 \mathrm{~mL}$ foi adicionado $60 \mu \mathrm{L}$ de HEBS 2 vezes concentrado e sob leve agitação foi acrescentado a mistura de água, DNA e $\mathrm{CaCl}_{2}$ "gota a gota" seguida de homogeneização; a solução foi incubada a temperatura ambiente por 20 minutos e adicionada ao poço de cultura "gota a gota", por fim a placa foi levemente movimentada para homogeneizar e incubada em estufa, a $37^{\circ} \mathrm{C}$ por 24 horas.

A transfecção foi realizada com todas as construções vacinais e a presença do RNA mensageiro e da proteína codificada por elas foram avaliados após 24 horas de transfecção. Em todas as transfecções foram realizados dois controles, um com células sem transfecção e outro com o plasmídeo pGreen Lantern.gcc (cedido gentilmente pelo Prof. Dario Simões Zamboni) que apresenta o gene que codifica a proteína GFP (Green Fluorescent Protein), para visualização da transfecção em microcópio de fluorescência (Leica DMI 4000B).

\subsubsection{Análise da transcrição do RNA mensageiro}

\subsubsection{Extração do RNA total das células transfectadas}

Após 24 horas de cultura foi retirado o meio de cultura das células, adicionado $500 \mu \mathrm{L}$ de Trizol (Invitrogen), sendo as células homogeneizadas, coletadas em tubo de 1,5mL e incubadas por 3 minutos a temperatura ambiente (a extração do RNA mensageiro foi realizada juntando-se dois poços de cultura de cada transfecção com objetivo de ter maior número de células e as células transfectadas com as diferentes construções vacinais foram processadas 
separadamente). Após o período de incubação adicionou-se $200 \mu \mathrm{L}$ de clorofórmio, as células foram agitadas por 30 segundos e incubadas por 5 minutos a temperaura ambiente. A suspensão celular foi, então, centrifugada a $12000 \mathrm{~g}$, por 15 minutos a $4^{\circ} \mathrm{C}$, para recuperação da fase aquosa, na qual foi adicionado $700 \mu \mathrm{L}$ de isopropanol gelado. As amostras foram, em seguida, homogeneizadas e incubadas a $-20^{\circ} \mathrm{C}$ por 16 horas para precipitação do RNA. Após esse intervalo de tempo, todos os procedimentos foram realizados no gelo. As amostras foram centrifugadas $12000 \mathrm{~g}$ por 10 minutos a $4^{\circ} \mathrm{C}$, o sobrenadante foi descartado e $1 \mathrm{~mL}$ de etanol a $70 \%$ ** adicionado. Foi realizada uma centrifugação a $7500 \mathrm{~g}$, por 5 minutos a $4^{\circ} \mathrm{C}$ e o sobrenadante descartado; após uma secagem de 10 minutos, o RNA foi ressuspendido em $20 \mu \mathrm{L}$ de água DEPC (Sigma), quantificado no aparelho GeneQuant $\mathrm{II}^{\mathrm{TM}}$ e analisado em gel de agarose a $1 \% * *$.

** Etanol a 70\% e o tampão utilizado no gel de agarose foram feitos com água DEPC segundo as instruções do fabricante.

\subsubsection{Transcrição reversa e avaliação da presença dos transcritos}

Após a extração e caracterização do RNA, $1 \mu \mathrm{g}$ foi tratado com 1 unidade de DNAse I (Invitrogen) e tampão (10X DNAse buffer), em um volume final de $10 \mu \mathrm{L}$ (completado com água ultrapure - Invitogen), por 15 minutos a $25^{\circ} \mathrm{C}$. Após esse período, a enzima foi inativada com 2,5mM de EDTA (Invitrogen), por 15 minutos a $65^{\circ} \mathrm{C}$.

A produção do cDNA, de cada RNA obtido das células transfectadas com as distintas construções vacinais, foi realizada incubando-se os $10 \mu \mathrm{L}$ da reação acima juntamente com $0,5 \mu \mathrm{g}(0,1 \mathrm{nmol})$ de oligo dT (Fermentas) e 0,5mM de dNTPs (Invitrogen), por 5 minutos a $65^{\circ} \mathrm{C}$. Após esse período, foram adicionados first-strand buffer 0,625X (Invitrogen), $0,01 \mu \mathrm{M}$ de dtt (Invitrogen), $2 \mu \mathrm{L}$ de água, $0,625 \mathrm{mM}$ de $\mathrm{MgCl}_{2}$ (Invitrogen) e 200 unidades da Superscript II (Invitogen). As amostras foram incubadas por 50 minutos a $42^{\circ} \mathrm{C}$ e, em seguida, a $70^{\circ} \mathrm{C}$ por 15 minutos. 
A detecção dos transcritos de cada cDNA foi realizada por PCR utilizando-se o programa VAC e $2 \mu \mathrm{L}$ do cDNA, $0,1 \mu \mathrm{M}$ de cada oligonucleotídeo**, $0,2 \mathrm{mM}$ de cada dNTPs, tampão da enzima, $1,5 \mathrm{mM}$ de $\mathrm{MgCl}_{2}$ e 1 unidade da enzima Taq DNA polimerase, em um volume final de $20 \mu \mathrm{L}$. O produto da PCR foi analisado em gel de agarose a $1 \%$.

**Os oligonucleotídeos utilizados para detectar os transcritos de todas as construções vacinais (pVAXgD, pVAXgDVac1AA, pVAXgDVac1PA e pVAXgDVac2) foram FgDPvu e $\operatorname{RgDApa}$, que hibridizam no interior da $\mathrm{gD}$, identificando a presença desta e das construções Vac1 e Vac2 e como controle dos experimentos foi amplificado o gene constitutivo GAPDH. Além disso, para detectar o transcrito pVAXgDVac1PA e o gene GAPDH foram utilizados 0,4 $\mu \mathrm{M}$ de cada oligonucleotídeo, os outros componentes da PCR foram utilizados na mesma concentração e o volume final foi de $25 \mu \mathrm{L}$.

GAPDH sense 5' ACCCACTCCTCCACCTTTG 3'

GAPDH antisense 5' CTCTTGTGCTCTTGCTGG 3'

\subsubsection{Análise da expressão das proteínas recombinantes (“Western blot")}

Após 24 horas de cultura foi retirado o meio de cultura das células, sendo essas

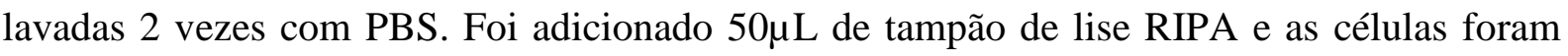
lisadas, coletadas e incubadas no gelo por 10 minutos. Em seguida, foram centrifugadas por 10 minutos a $10000 \mathrm{~g}, 4^{\circ} \mathrm{C}$ e separado sedimento e sobrenadante.

O sedimento foi acrescido de $20 \mu \mathrm{L}$ de água e homegeneizado, $20 \mu \mathrm{L}$ do meio de cultura retirado das células e $20 \mu \mathrm{L}$ do sobrenadante foram separados e a todas essas amostras foi adicionado $5 \mu \mathrm{L}$ de tampão da amostra 5 vezes concentrado. As amostras foram, então, fervidas por 5 minutos e submetidas a eletroforese em gel a 10\%, por 20 minutos, a $50 \mathrm{~V}$ e em seguida 1,5 hora a $100 \mathrm{~V}$.

Após a eletroforese as proteínas foram transferidas para uma membrana de nitocelulose por 1,5 hora a $100 \mathrm{~V}$,em seguida, a membrana foi incubada com tampão de 
bloqueio (PBS, 2\% de BSA, 0,05\% de Tween 20) por 2 horas a temperatura ambiente, lavada (PBS-T) e incubada com os anticorpos anti-Vac1 policlonal, anti-Vac2 policlonal ou anti-gD (gentilmente cedido pelo Professor Luis Carlos de Souza Ferreira - ICBII/USP - São Paulo) (para as transfecções com pVAXgDVac1PA ou pVAXgDVac1AA utilizou-se a anticorpo anti-gD e anti-Vac1 e para a transfecção com pVAXgDVac2, anticorpo anti-gD e anti-Vac2) diluídos 1:1000 (anti-Vac1 e anti-Vac2) e 1:20000 (anti-gD) em tampão bloqueio, a $4^{\circ} \mathrm{C}$ por 16 horas. A membrana foi, então, novamente lavada e incubada com o anticorpo de cabra contra IgG de camundongo marcado com peroxidase diluído 1:5000, por 1 hora a temperatura ambiente e revelada com peróxido de hidrogênio e DAB (protocolo de Western idem item 4.9.1).

\subsection{Avaliacão da resposta imunológica}

\subsubsection{Imunização}

Após as construções e caracterizações das vacinas pVAXgD, pVAXgDVac1AA, pVAXgDVac1PA e pVAXgDVac2, elas foram utilizadas nos experimentos de imunogenicidade. Para isso camundongos isogênicos da linhagem BALB/c (fêmeas), com 7-8 semanas de idade, provenientes do Biotério de Animais Isogênicos da Faculdade de Medicina de Ribeirão Preto-USP, foram utilizados nos ensaios de imunização, segundo os princípios éticos adotado pelo COBEA e condições estabelecidas pelo nosso grupo, com inoculação nos músculos quadríceps (direito e esquerdo) em regime vacinal de 4 doses de $100 \mu \mathrm{g}$ de DNA/dose, obedecendo um intervalo de 2 semanas entre cada dose e avaliação dos resultados 30 dias após a última dose. Os grupos utilizados nesse trabalho foram: (n = 6 a 14 animais/grupo) 
a. pVAXgD (plasmídeo pVAX + gene da glicoproteína D do HSV-1);

b. pVAXgDVac1AA (plasmídeo pVAX + a gD e os 5 epítopos da Hsp65);

c. pVAXgDVac1PA (plasmídeo pVAX + a gD sem sua porção central e os 5 epítopos da Hsp65);

d. pVAXgDVac2 (plasmídeo pVAX+ a gD e os 5 epítopos da Hsp65 em duplicata);

e. pVAX (plasmídeo pVAX-Invitrogen);

f. pVAXHsp65 (plasmídeo pVAX + gene da Hsp65 completo);

g. Salina.

Os animais durante todo protocolo experimental foram mantidos em isoladores de animais, com temperatura, umidade, fluxo de ar e ciclo de luz claro/escuro controlados, com livre acesso a água e ração.

\subsubsection{Avaliação da resposta imunológica humoral}

A resposta imunológica humoral foi avaliada pela detecção de anticorpos IgG1 e IgG2a específicos contra as proteínas Hsp65, Vac1 e Vac2, por ELISA, nas amostras de soro pré-imune (coletados antes das imunizações) e soros coletados 30 dias após a última imunização através do plexo-retro orbital. Placas de 96 poços de poliestireno (Maxisorp Nunc-Immuno Plates, USA) foram sensibilizadas com $100 \mu \mathrm{L} /$ poço da solução de proteína Hsp65 ou Vac1 e Vac2 diluídas em tampão de ligação $\left(15 \mathrm{mM}\right.$ de $\mathrm{Na}_{2} \mathrm{CO}_{3}$ e $35 \mathrm{mM}$ de $\left.\mathrm{NaHCO}_{3}, \mathrm{pH} 9,6\right)$ em uma concentração final de $5 \mu \mathrm{g} / \mathrm{mL}$. As placas foram incubadas a $4^{\circ} \mathrm{C}$ por 16 horas e posteriormente lavadas com PBS-T e bloqueadas com $200 \mu \mathrm{L}$ ppoço de uma solução PBS contendo $10 \%$ de SBF e $0,05 \%$ de Tween 20. Após incubação por 1 hora, a $37^{\circ} \mathrm{C}$, as placas foram novamente lavadas e adicionou-se $100 \mu \mathrm{L} /$ poço dos soros, diluídos 1:10, 1:100, 1:500 e 1:1000, em solução de bloqueio. As placas foram incubadas por 2 horas, a $37^{\circ} \mathrm{C}$, e após lavagem das mesmas, foi realizada incubação por 1 hora, a $37^{\circ} \mathrm{C}$, com anticorpo monoclonal anti-IgG1 (A85-1) ou anti-IgG2a (R19-15) conjugados com biotina (BD 


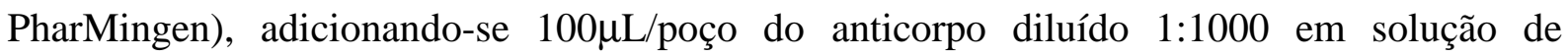
bloqueio. Após procedimento de lavagem, foi adicionada $100 \mu \mathrm{L} /$ poço da solução de avidina biotina peroxidase StrepAB kitTM (Dako), sendo incubada por 30 minutos a temperatura ambiente. As placas foram reveladas pela adição de peróxido de hidrogênio e OPD (SigmaFast OPD) e a reação foi interrompida pela adição de $50 \mu \mathrm{L} /$ poço de ácido sulfúrico a 16\%. A leitura da absorbância foi realizada em espectrofotômetro de placa ( $\mu$ Quant Bio-Tek Instruments Inc.) a 490nm.

\subsubsection{Avaliação da resposta imunológica celular}

Trinta dias após a última imunização, os animais foram sacrificados utilizando-se o anestésico Ketamina, na concentração de $100 \mathrm{mg} / \mathrm{Kg}$ de massa corpórea, por via endovenosa. O baço de cada animal foi retirado assepticamente e incubado em $2 \mathrm{~mL}$ de meio RPMI-1640 incompleto (Sigma-Aldrich) separadamente. Em seguida, o órgão foi macerado entre um pedaço de organza com o auxílio do embôlo de uma seringa, o macerado foi centrifugado a $480 \mathrm{~g}$, por 5 minutos a $4^{\circ} \mathrm{C}$. O sobrenadante foi descartado e o sedimento tratado com $2 \mathrm{~mL}$ de tampão de lise $\mathrm{ACK}\left(0,15 \mathrm{M}\right.$ de $\mathrm{NH}_{4} \mathrm{Cl}, 10 \mathrm{mM}$ de $\mathrm{KHCO}_{3}$ e $0,1 \mathrm{mM}$ de EDTA, pH 7,3), por 2 minutos a $4^{\circ} \mathrm{C}$ para lise das hemácias. À suspensão foi acrescentado $10 \mathrm{~mL}$ de PBS sendo, em seguida, centrifugada a $480 \mathrm{~g}$, por 5 minutos a $4^{\circ} \mathrm{C}$. O sobrenadante foi descartado e o sedimento ressuspendido em $1 \mathrm{~mL}$ de RPMI completo (RPMI incompleto acrescido de $10 \%$ de $\mathrm{SBF}, 1 \%$ de estreptomicina/penicilina, $30 \mu \mathrm{g} / \mathrm{mL}$ de polimixina-P-4932, Sigma, $10 \mu \mathrm{g} / \mathrm{mL}$ de Gentamicina-Gibco e $50 \mu \mathrm{M}$ de 2-mercaptoetanol-Sigma) (RPMI-C). As células foram contadas em câmara de Neubauer (Boeco) e ajustadas para uma concentração final de $5 \times 10^{6}$ células/mL em RPMI-C. 


\subsubsection{Proliferação de linfócitos $T$}

Parte da suspensão celular obtida no item 4.11 .3 foi distribuída em placas de 96 poços ( $5 \times 10^{5}$ células/poço) (Corning) e estimuladas in vitro com meio, $4 \mu \mathrm{g} /$ poço de mitógeno concanavalina A (ConA) (Sigma) e $2 \mu \mathrm{g} /$ poço das proteínas recombinantes Hsp65, Vac1 e Vac2, em poços separados e incubadas a $37^{\circ} \mathrm{C}, 5 \%$ de $\mathrm{CO}_{2}$.

Após 62 horas de cultura foi adicionado $0,5 \mu \mathrm{Ci}$ de $\left[{ }^{3} \mathrm{H}\right]$-timidina/poço sendo as células incubadas por mais 10 horas. Após o período de incubação, as amostras foram coletadas e analisadas em um contador de cintilação beta LS6500 (Beckman).

\subsubsection{Produção de citocinas}

Para dosagem de citocinas, parte da suspensão celular obtida no item 4.11.3 foi distribuída em placas de 24 poços $\left(5 \times 10^{6}\right.$ células $/ \mathrm{mL} /$ poço $)$, estimulada in vitro com meio

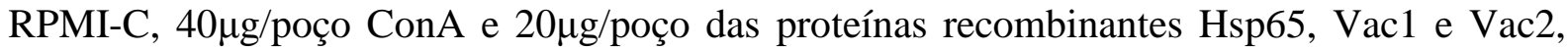
em poços separados e incubadas a $37^{\circ} \mathrm{C}, 5 \%$ de $\mathrm{CO}_{2}$.

Após 48 horas de cultura, as placas foram centrifugadas a $480 \mathrm{~g}$, por 5 minutos e o sobrenadante coletado e avaliado quanto à produção de IFN- $\gamma$, IL-12, IL-2, IL-5 e IL-10, por ELISA. Placas de 96 poços de poliestireno foram sensibilizadas com $100 \mu \mathrm{L}$ da solução de anticorpo monoclonal purificado específico para a citocina de interesse (BD PharMingen), diluído em tampão de ligação $\left(\mathrm{Na}_{2} \mathrm{HPO}_{4}\right.$ a $0,1 \mathrm{M}, \mathrm{pH}$ 9,0), em uma concentração final de $1 \mu \mathrm{g} / \mathrm{mL}$ (para IL-10, $2 \mu \mathrm{g} / \mathrm{mL}$ ). As placas foram incubadas a $4^{\circ} \mathrm{C}$ por 16 horas e após sucessivas lavagens com solução PBS-T, foram incubadas com $200 \mu \mathrm{L} /$ poço da solução de bloqueio, constituída de PBS contendo $10 \%$ de SBF por 1 hora, a temperatura ambiente. As placas foram novamente lavadas e as amostras foram adicionadas, $100 \mu \mathrm{L} /$ poço juntamente com a curva padrão da citocina recombinante, diluída em tampão de bloqueio com $0,05 \%$ de Tween 20, e incubada por 16 horas a $4^{\circ} \mathrm{C}$. Após lavagem, foi feita incubação por 1 hora, a 
temperatura ambiente, com anticorpo monoclonal conjugado com biotina específico para a citocina de interesse (BD PharMingen), adicionando-se $100 \mu \mathrm{L} /$ poço do anticorpo diluído em tampão de bloqueio com $0,05 \%$ de Tween 20 em uma concentração final de $0,5 \mu \mathrm{g} / \mathrm{mL}$ (para IL-10, $1 \mu \mathrm{g} / \mathrm{mL})$. Após lavagem, adicionou-se $100 \mu \mathrm{L} /$ poço de solução de avidina biotina peroxidase StrepAB kitTM sendo incubada por 30 minutos a temperatura ambiente. As placas foram reveladas pela adição de peróxido de hidrogênio e OPD após novo procedimento de lavagem. A reação foi interrompida pela adição de $50 \mu \mathrm{L} /$ poço de ácido sulfúrico $16 \%$. A leitura da absorbância foi realizada em espectrofotômetro de placa a 490nm. A determinação das concentrações das citocinas foi feita por interpolação dos resultados de absorbância obtidos nas amostras em relação aos da curva padrão utilizando-se o programa Instat 3.

\begin{tabular}{|c|c|c|c|}
\hline & & Anticorpo Purificado & Anticorpo Biotinilado \\
\hline IFN- $\gamma$ & $\begin{array}{l}\text { Clone } \\
\text { Isotipo }\end{array}$ & $\begin{array}{l}\text { R4-6A2 } \\
\text { Rat IgG1 }\end{array}$ & $\begin{array}{l}\text { XGM1.2 } \\
\text { Rat IgG1 }\end{array}$ \\
\hline IL-10 & $\begin{array}{l}\text { Clone } \\
\text { Isotipo }\end{array}$ & $\begin{array}{l}\text { JES5-2A5 } \\
\text { Rat IgG1 }\end{array}$ & $\begin{array}{l}\text { SXC-1 } \\
\text { Rat IgM }\end{array}$ \\
\hline IL-5 & $\begin{array}{l}\text { Clone } \\
\text { Isotipo }\end{array}$ & $\begin{array}{l}\text { TRFK5 } \\
\text { Rat IgG1 }\end{array}$ & $\begin{array}{l}\text { TRFK4 } \\
\text { Rat IgG2a }\end{array}$ \\
\hline IL-12 & $\begin{array}{l}\text { Clone } \\
\text { Isotipo }\end{array}$ & $\begin{array}{l}\text { 9A5 } \\
\text { Rat IgG2b }\end{array}$ & $\begin{array}{l}\text { C17.8 } \\
\text { Rat IgG2a }\end{array}$ \\
\hline IL-2 & $\begin{array}{l}\text { Clone } \\
\text { Isotipo }\end{array}$ & $\begin{array}{l}\text { JES6-1A12 } \\
\text { Rat IgG2a }\end{array}$ & $\begin{array}{l}\text { JES6-5H4 } \\
\text { Rat IgG2b }\end{array}$ \\
\hline
\end{tabular}

\subsubsection{Fenótipo celular}

A fim de estudar o perfil das populações de linfócitos $\mathrm{T}$ dos grupos de animais imunizados, foi realizada a análise dos marcadores de superfície celular CD4, CD8, CD44 e CD62L pela técnica de citometria de fluxo. As células cultivadas (item 4.11.3), após a retirada do sobrenadante para dosagem de citocinas, foram retiradas com $1 \mathrm{~mL}$ de PBS, coletadas em um tubo de $1,5 \mathrm{~mL}$ e centrifugadas a $12 \mathrm{~g}$, por 5 minutos a $4^{\circ} \mathrm{C}$. O sobrenadante foi descartado, o sedimento ressuspendido em $200 \mu \mathrm{L}$ de Fc-block (sobrenadane de cultura do clone 2,4G2PharMingen) (diluído1:1 em RPMI-I ou PBS) e incubado por 30 minutos a $4^{\circ} \mathrm{C}$. Em seguida, 
$100 \mu \mathrm{L}$ da suspensão celular foram distribuídas em dois tubos e os anticorpos foram adicionados $(0,7 \mu \mathrm{L}$ de cada anticorpo): uma marcação foi feita com CD4-PE (ficoeritrina), CD44-PECy (ficoeritrina Cy-chrome) e CD62L-FITC (isotiocianato de fluoresceína) e a outra com CD8-PECy, CD44PE e CD62L-FITC. As células foram incubadas por 30 minutos a temperatura ambiente no escuro, lavadas com $2 \mathrm{~mL}$ de PBS contendo $2 \%$ de SBF e centrifugadas a $480 \mathrm{~g}$, por 5 minutos a $4^{\circ} \mathrm{C}$. O sobrenadante foi descartado e, o sedimento ressuspendido em $200 \mu \mathrm{L}$ de PBS contendo $0,1 \%$ de formaldeído. As amostras foram adquiridas em aparelho FACSort (Becton \& Dickinson), coletando-se 30.000 eventos por amostra. Um tubo apenas com células e outros com células mais isotipos controles (PE-Rat IgG2 $\mathrm{a}_{\kappa} ;$ PECy-Mouse IgG2 $\mathrm{a}_{\kappa}$, FITC-Mouse $\operatorname{IgG} 1_{\kappa}$ ) foram utilizados em todos os experimentos para o ajuste das fluorescências.

\subsubsection{Análise Estatística}

A análise estatística dos resultados foi realizada com cut-off ou teste t não-pareado para comparar os dados entre os diferentes grupos experimentais. Foram considerados significativos os resultados cujas diferenças apresentaram $p<0,05$. 


\subsection{RESULTADOS}

\section{$\underline{5.1 \text { Construcão da vacina pVAXgD }}$}

\subsubsection{Clivagem do vetor pRE4}

O vetor pRE4, com aproximadamente 4500 pares de base (pb), clivado com a enzima HindIII liberou um fragmento de tamanho aproximado a $1500 \mathrm{pb}$, indicando a retirada do gene da gD (1423pb) (Figura 4) que foi purificada para posterior clonagem no vetor pVAX.

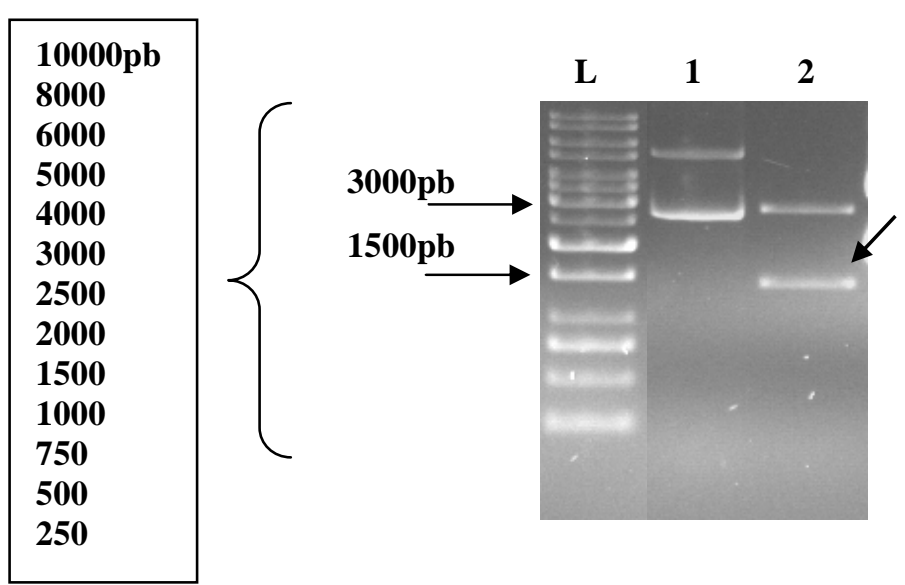

Figura 4: Digestão do vetor pRE4 com a enzima HindIII. L-marcador de $1 \mathrm{~Kb}$ (Fermentas), 1-pRE4 não digerido, 2-pRE4 digerido com HindIII, retirada do fragmento gD.

\subsubsection{Clivagem do vetor $\mathrm{pVAX}$}

A linearização do vetor pVAX utilizando a enzima HindIII para posterior clonagem da $\mathrm{gD}(1423 \mathrm{pb})$ foi visualizada em gel de agarose a $1 \%$ (Figura 5). 


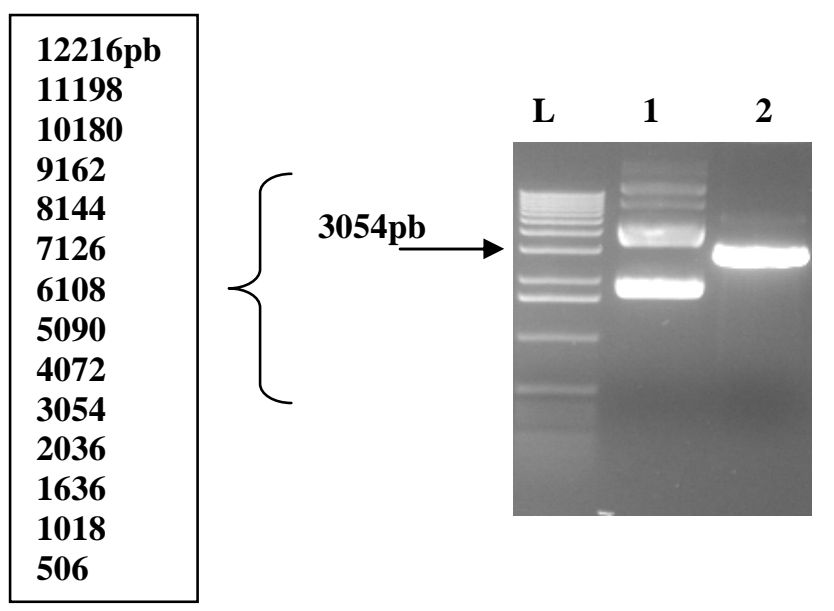

Figura 5: Digestão do vetor pVAX com a enzima HindIII. L-marcador de 1Kb (Invitrogen), 1-pVAX não digerido, 2-pVAX digerido com HindIII para linearização.

A linearização é identificada pela presença de uma única banda no tamanho do vetor, 3000pb, isto é, após a clivagem as três conformações do plasmídeo são perdidas ficando todas abertas em um único fragmento.

O plasmídeo foi, em seguida, desfosforilado e purificado para posterior ligação com a gD. A desfosforilação foi realizada com uma fosfatase alcalina para remoção do fosfato 5' terminal, evitando assim a recircularização do DNA plasmidial e facilitando a clonagem com o inserto de interesse (Sambrook, 1989).

\subsubsection{Clonagem da gD no vetor $\mathrm{pVAX}$}

Duas ligações foram realizadas entre o fragmento $\mathrm{gD}$ e o vetor $\mathrm{pVAX}$, ambas foram utilizadas na transformação de células de E. coli Top10 competentes.

Os plasmídeos de dez colônias da primeira ligação entre pVAX e gD foram extraídos e submetidos a reação de clivagem utilizando-se as enzimas $P v u \mathrm{II}$ e NotI. Como a enzima $P v u I I$ cliva dentro do gene da $\mathrm{gD}$ e a NotI no vetor $\mathrm{pVAX}$ é possível verificar além da presença do fragmento a direção dele no interior desse vetor. A verificação da direção do fragmento dentro do plasmídeo é importante, pois insertos clivados apenas com uma enzima (no caso apenas 
HindIII) podem se ligar ao plasmídeo nas direções correta ou invertida. O produto da digestão foi analisado em gel de agarose a $1 \%$ (Figura 6).

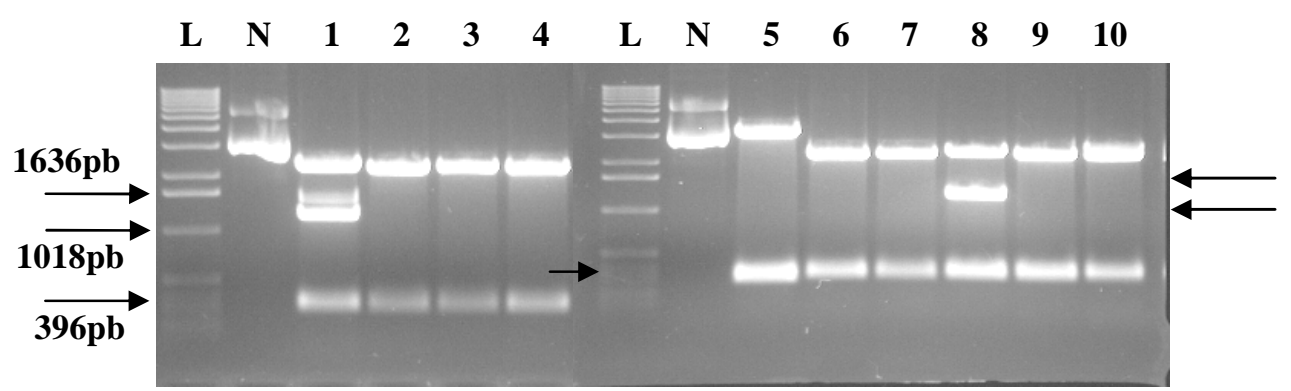

Figura 6: Digestão dos clones pVAXgD. Digestão de 10 clones da primeira ligação entre pVAX e gD com as enzimas $P v u I I$ e NotI, L-marcador de $1 \mathrm{~Kb}, \mathrm{~N}-\mathrm{pVAXgD}$ não digerido (um dos clones não digerido usado como controle), 1 a 10-digestão dos clones 1 a 10 da primeira ligação entre pVAX e gD.

Apenas dois clones, pVAXgD_1 e 8, provavelmente eram recombinantes, apresentando a gD na direção correta, isso devido ao fragmento liberado de tamanho entre 1018-1636pb, a clivagem com essas enzimas nos clones positivos para a gD na direção correta geram um fragmento de 1263 pb que foi visto na digestão acima. No entanto, também foi produzido um fragmento de aproximadamente $396 \mathrm{pb}$ que não era esperado, esse fragmento estava presente em todos os clones por isso acreditamos que provavelmente a enzima $P v u I I$ tenha digerido o vetor $\mathrm{pVAX}$ em algum sítio não específico, pois essa endonuclease apresenta "star activity" que é a digestão de sítios não específicos em condições não ótimas ocasionadas pela utilização de um tampão que não é específico dela ou pela própria concentração da enzima (Polisky, Greene et al., 1975; Woodbury, Hagenbuchle et al., 1980).

Os plasmídeos dos clones pVAXgD_1 e 8 também foram digeridos separadamente com as enzimas HindIII, que flanqueia a gD, e ApaI, que cliva no interior do pVAX e da gD, para verificar a liberação do fragmento da $\mathrm{gD}$ e confirmar sua direção, respectivamente. As clivagens foram analisadas em gel de agarose a 1\% (Figura 7). 


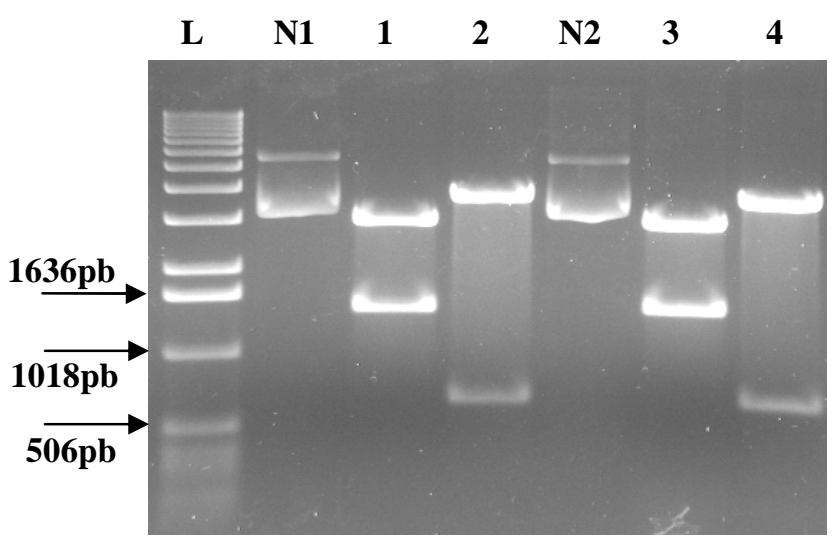

Figura 7: Digestão dos clones pVAXgD. Digestão dos clones pVAXgD_1 e 8 da primeira ligação entre pVAX e gD com as enzimas HindIII e ApaI separadamente. L-marcador de $1 \mathrm{~Kb}, \mathrm{~N} 1-\mathrm{pVAXgD} 1$ não digerido, 1pVAXgD_1 digerido com HindIII, 2-pVAXgD_1 digerido com ApaI, N2-pVAXgD_8 não digerido, 3pVAXgD_8 digerido com HindIII, 4-pVAXgD_8 digerido com ApaI.

Os clones apresentaram fragmento próximo a $1636 \mathrm{pb}$ que indica a presença da gD (1423pb) quando clivado com HindIII e fragmento próximo a 506pb, quando clivado com ApaI, tamanho esperado (639pb) para a inserção de apenas um fragmento gD no vetor pVAX e na posição correta.

Como apenas dois clones foram encontrados na primeira ligação uma nova clonagem foi realizada e a seleção de plasmídeos recombinantes $\mathrm{pVAXgD}$ foi feita inicialmente realizando um PCR de 10 colônias utilizando-se os oligonucleotídeos T7, que hibridiza no vetor $\mathrm{pVAX}$, e FgDApa que anela no interior da $\mathrm{gD}$, dessa forma, foi possível verificar a presença da gD e sua direção no interior do vetor. O produto da PCR foi analisado em gel de agarose a $1 \%$ (Figura 8$)$.

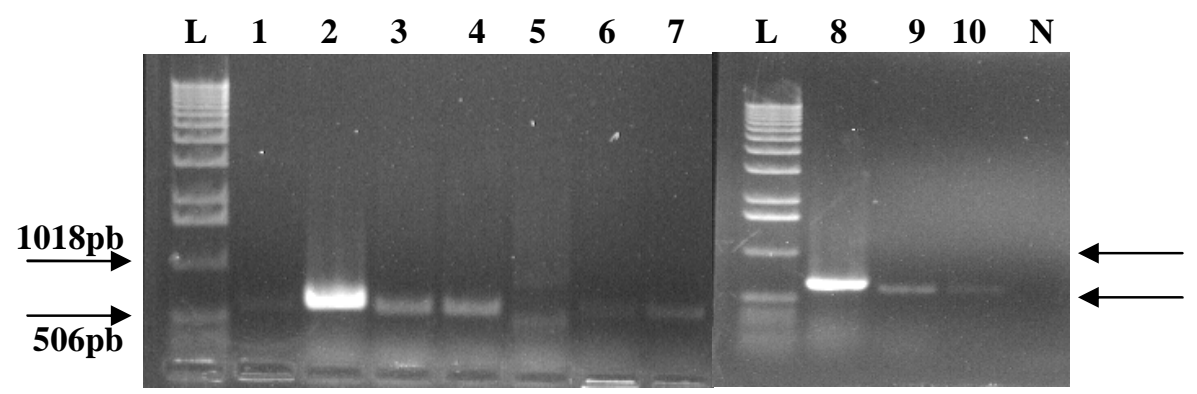

Figura 8: PCR dos clones pVAXgD. PCR de 10 colônias da segunda ligação entre pVAX e gD. L-marcador de $1 \mathrm{~Kb}, 1$ a 10-PCR das colônias 1 a 10 da segunda ligação entre pVAX e gD, N-negativo (controle, utiliza-se todos os reagentes para a amplificação exceto DNA molde que é substituído por água) . 
Quatro clones pVAXgD_1, 5, 6 e 10 apresentaram fragmento de amplificação muito fraco podendo assim não apresentar a gD ou apresentá-la na direção correta (nesse caso ambos os primers utilizados T7 e FgDApa funcionam como sense, na mesmo direção), as outras colônias com fragmento entre 506-1018pb (661pb) provavelmente apresentavam a gD na direção invertida (T7 funciona como sense e FgDApa como antisense).

Os plasmídeos dessas quatro colônias foram extraídos juntamente com outras cinco novas colônias da mesma ligação e foram submetidos a duas reações de clivagem, uma com as enzimas PvuII e NotI (Figura 9A), anteriormente utilizadas na procura de recombinantes da primeira ligação, e a outra com a enzima HindIII (Figura 9B) que libera o fragmento da gD nos clones positivos para essa seqüência. Se no pVAX não tiver ligado a gD o vetor apenas lineariza. As digestões foram analisadas em gel de agarose a 1\% (Figura 9).
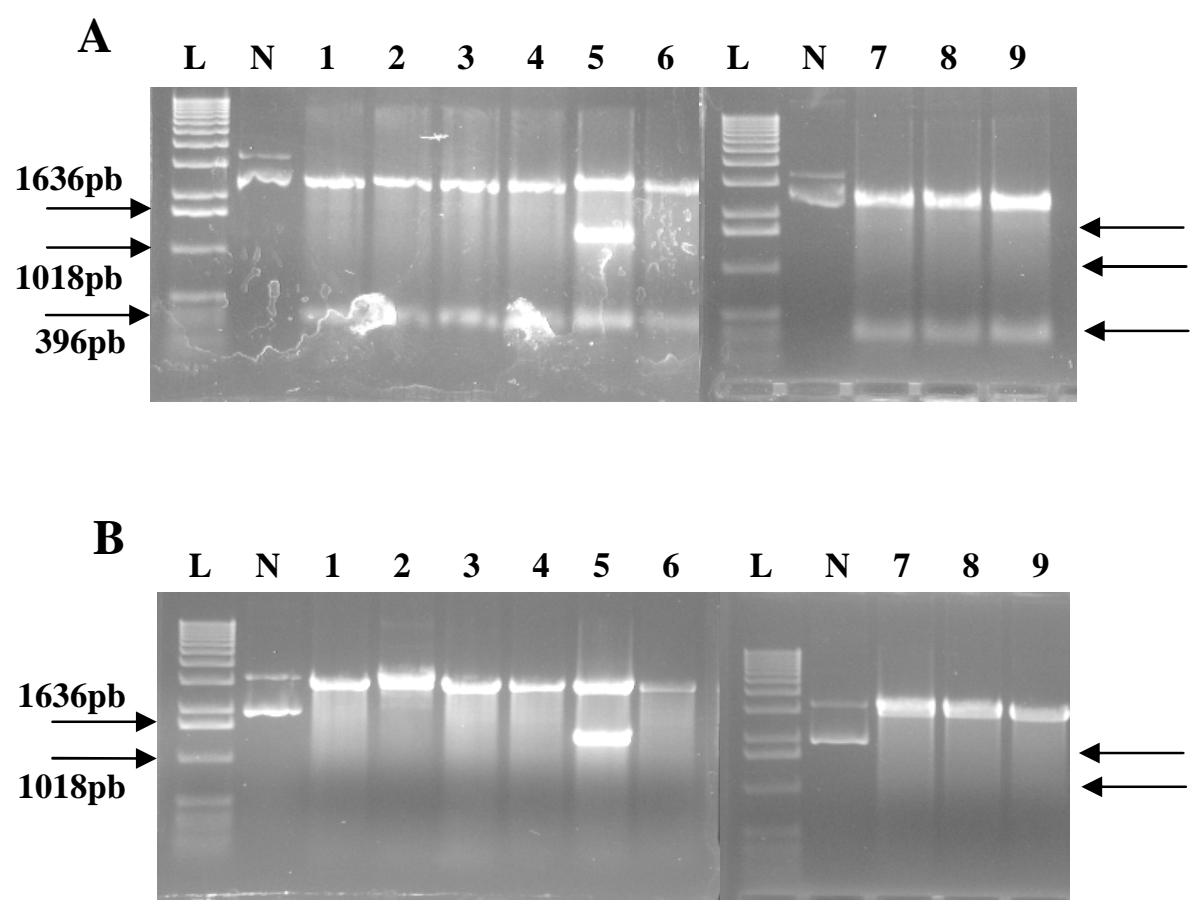

Figura 9: Digestão dos clones pVAXgD. Digestão de 9 clones da segunda ligação entre pVAX e gD (clones 1, 5,6 e 10 que possivelmente eram positivos segundo a PCR e cinco clones novos) com as enzimas A) $P v u I I$ e NotI e com a enzima B) HindIII L-marcador de $1 \mathrm{~Kb}, \mathrm{~N}-\mathrm{pVAXgD}$ não digerido, 1 a 9-digestão dos clones 1 a 9 da ligação entre pVAX e gD (sendo as canaletas 1, 5, 6 e 9 representadas pelos clones 1, 5, 6 e 10 citados anteriormante). 
Apenas o clone pVAXgD_5 apresentou fragmento entre 1018-1636pb (1263pb) na clivagem com PvuII e NotI (Figura 9A), tamanho semelhante ao visto nos clones pVAXgD_1 e 8 da primeira ligação, e um fragmento próximo a 1636pb (Figura 9B) que indica a presença da gD (1423pb) quando clivado com HindIII.

Ainda investigando se o clone pVAXgD_5 era recombinante e apresentava a gD na direção correta ele foi submetido a uma reação de clivagem com a enzima ApaI. A digestão foi analisada em gel de agarose a $1 \%$ (Figura 10).

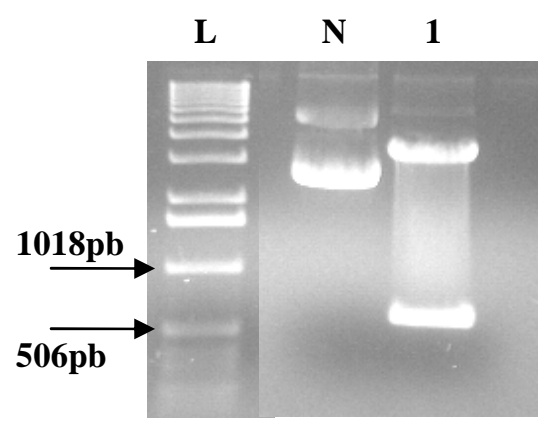

Figura 10: Digestão do clone pVAXgD_5 com a enzima $\mathbf{A p a I}$. L-marcador de $1 \mathrm{~Kb}, \mathrm{~N}-\mathrm{pVAXgD} 5$ não digerido e 1-digestão pVAXgD_5 com ApaI.

O clone pVAXgD_5 apresentou fragmento próximo a 506pb tamanho esperado (639pb) para a inserção de apenas um fragmento gD no vetor pVAX e na posição correta.

A partir dos resultados obtidos com a análise de restrição, os três plasmídeos recombinantes, pVAXgD_1, 5 e 8, foram analisados por seqüenciamento utilizando-se os oligonucleotídeos T7, BGH e FgDApaseq para confirmação da seqüência e o clone pVAXgD_1 (Figura 11) foi escolhido para posterior utilização nos ensaios in vitro e in vivo. 
A

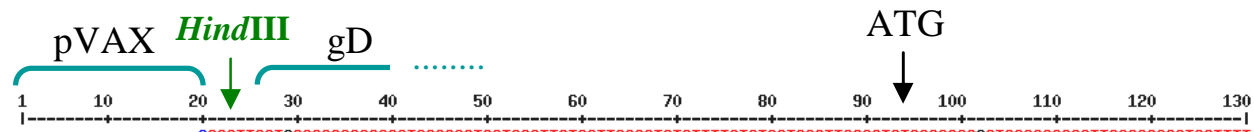

PYAXgD

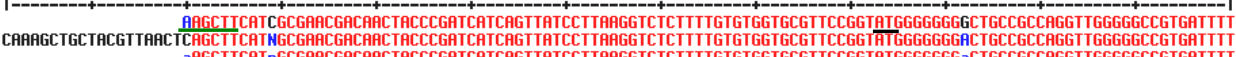
Consensus

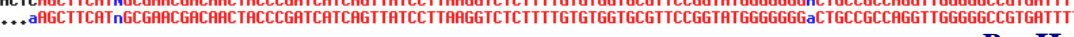

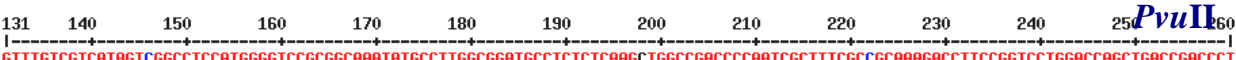

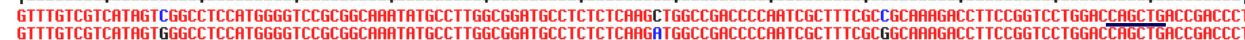
PYAXgD-1

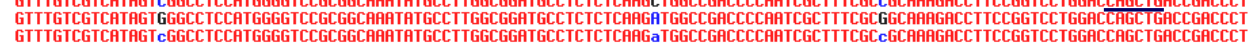

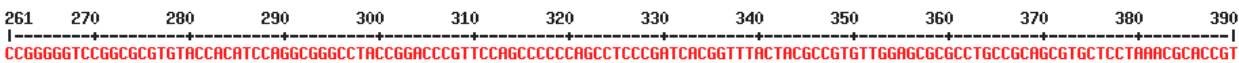

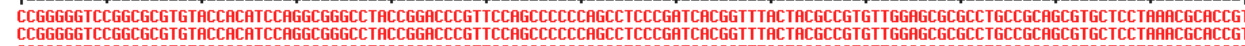

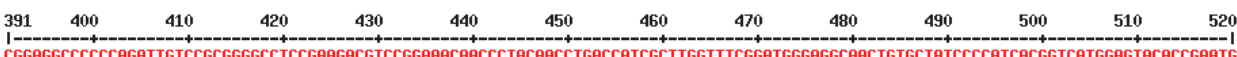

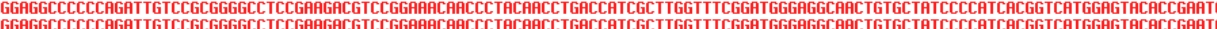
CGGAGGCCCCCCAGATTGTCCGCGGGGCCTCCGAAGACGTCCGGAAACAACCC TACAACCTGACCATCGCTTGGTTTCGGATGGGAGGCAAC TGTGCTATCCCCATCACGGTCATGGAGTACACCGAATG

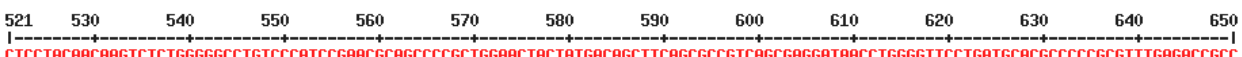

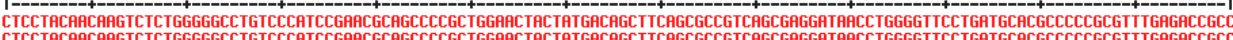

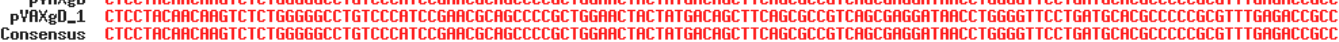

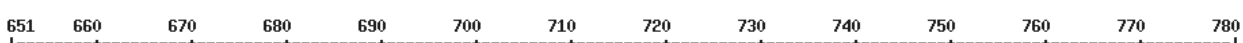

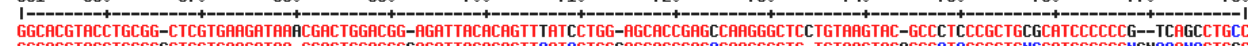
PNh

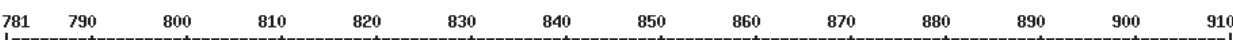

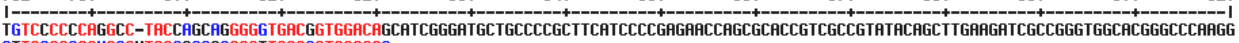
CNTACACAACAGGGTTGACAGTGGACAC

B

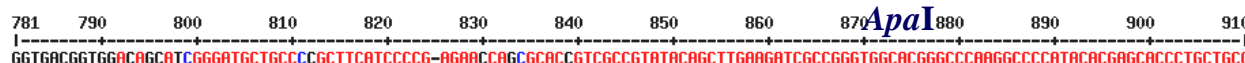

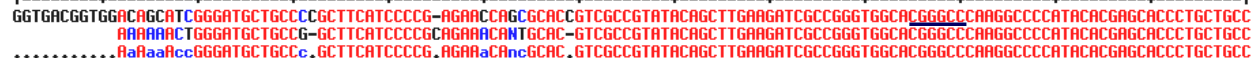

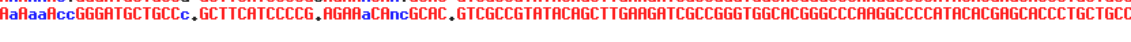

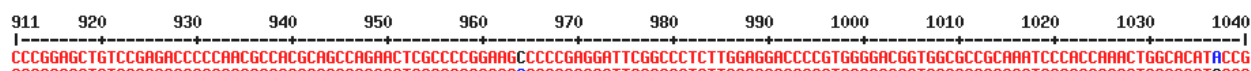
pPAXgD
pPHXgD_1

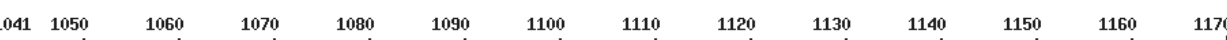

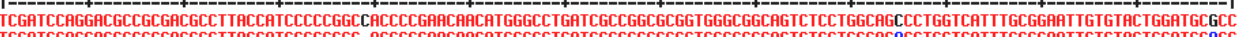

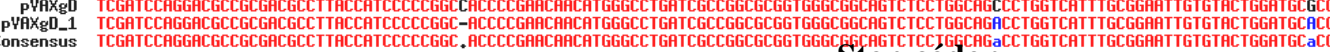

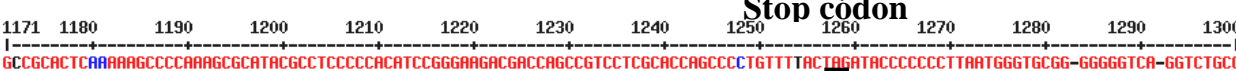

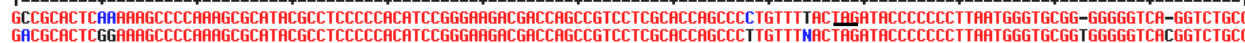

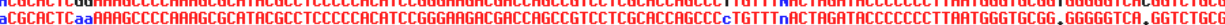

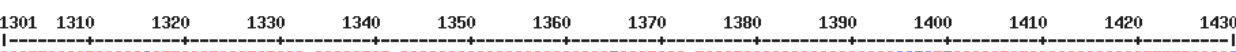

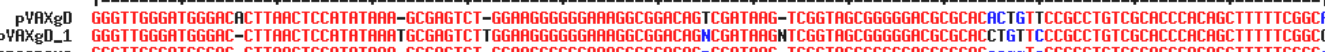

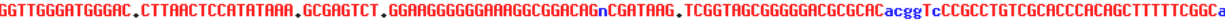

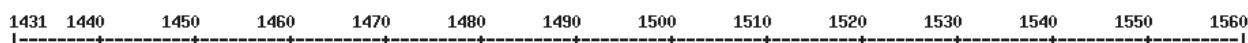

\section{pVAX}

Figura 11: Alinhamento do gene da gD com o clone pVAXgD_1. A) gD alinhada com o clone pVAXgD_1 seqüenciado com o primer T7, em destaque o sítio da enzima HindIII utilizada na retirada do fragmento, o início do gene da gD, o primeiro códon a ser traduzido em proteína (ATG) e o sítio da enzima $P v u \mathrm{II}$. B) gD alinhada com o clone pVAXgD_1 seqüenciado com o primer FgDApaseq, em destaque o sítio da enzima ApaI, o códon de terminação da tradução da proteína gD (TAG) e o final do gene da gD. (multalin-http://bioinfo.genopoletoulouse.prd.fr/multalin/multalin.html).

A partir do seqüenciamento foi possível visualizar o início (Figura 11A) e o fim (Figura 11B) do gene da proteína $\mathrm{gD}$, confirmando a presença de um único fragmento na direção correta no interior do vetor pVAX. 


\subsection{Construcão e amplificacão do molde Vac1}

As seqüências dos epitopos da proteína Hsp65 (Mustafa, Lundin et al., 1999; Charo, Geluk et al., 2001) (Tabela 1) estão distribuídas dentro da sequiência do gene hsp65 em diferentes sítios. Como não tínhamos um molde de DNA para ser usado na amplificação da seqüência Vac1 (5 epitopos da proteína Hsp65), foi necessário primeiro a construção desse molde (Tabela 2) (Figura 12) por meio de uma síntese gênica utilizando a PCR.

Para essa construção foram sintetizados primers que cobrissem toda a seqüência Vac1 com códons frequentemente encontrados em mamíferos, uma vez que ela seria utilizada para gerar proteína em células de mamíferos. Em seguida, utilizando-se o site http://www.kazusa.or.jp/codon/cgi-bin/showcodon.cgi?species modificou-se repetições de nucleotídeos desses primers que pudessem atrapalhar a síntese desse molde (as repetições podem favorecer inserções de bases pontualmente na hora da amplificação) (Griffiths, 1999). Essas mudanças consistiram nas substituições de bases em códons repetidos (aminoácidos repetidos) na seqüência da proteína de forma que ainda codificassem o mesmo aminoácido e tivessem uma alta freqüência em mamíferos (exemplo: alanina é codificada pelos códons GCU, GCC, GCA e GCG, foram escolhidos os três primeiros que são mais freqüentes em mamíferos e utilizados alternadamente na seqüência Vac1 para não haver muita repetição).

Após a obtenção dos primers, realizou-se a PCR para construção do molde Vac1 e o produto de amplificação foi analisado em gel de agarose a 2\% (Figura 12). 


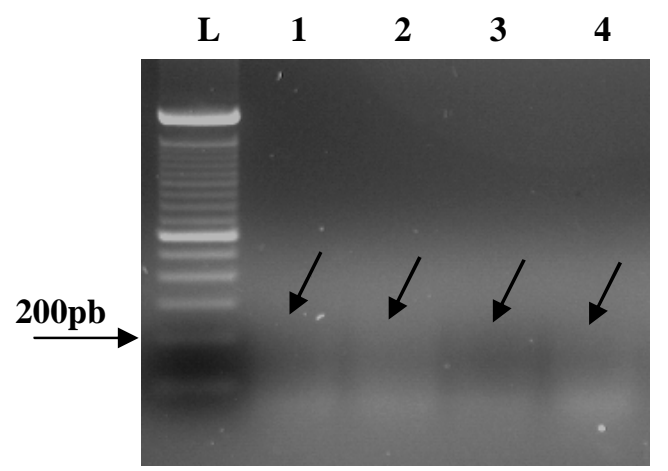

Figura 12: Construção do molde Vac1. Molde Vac1 formado pela seqüência dos cinco epitopos do gene da proteína Hsp65, usado na construção das vacinas de DNA utilizadas nesse projeto. L-marcador de 100pb (Invitrogen), 1 a 4-produtos da construção do molde utilizando TMs diferentes, $50^{\circ}-54,2^{\circ}-61^{\circ}-65^{\circ} \mathrm{C}$, respectivamente.

A síntese gênica revelou um fragmento de aproximadamente 200pb (208pb) difícil de ser documentado, mas foi esse molde (número 2) o utilizado na amplificação da Vac1 para clonagem no vetor pGEM-T. A reação de amplificação foi realizada apenas com os oligonucleotídeos F1Apa(curto) e R2Apa(curto) que hibridizam no inicio e fim do fragmento. O produto de amplificação denominado Vac1AA (apresenta o sítio da enzima ApaI nas duas extremidades 5' e 3') foi analisado em gel de agarose a 2\% (Figura 13).

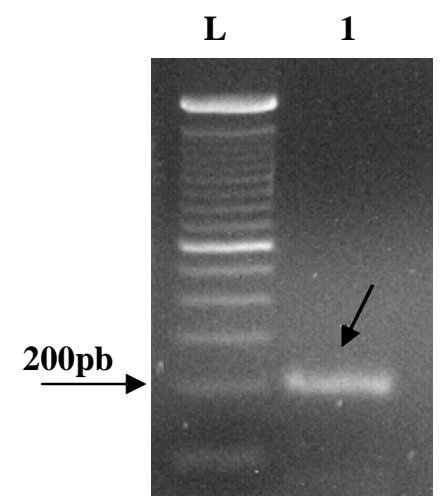

Figura 13: Amplificação do molde Vac1. Molde Vac1 denominado Vac1AA (apresenta o sítio da enzima ApaI nas duas extremidades 5' e 3'). L-marcador de 100pb, 1-Vac1 amplificada.

A amplificação gerou um fragmento de aproximadamente 200pb (207pb) que foi purificado e clonado no vetor pGEM-T. 


\subsection{Clonagem do fragmento Vac1AA no vetor pGEM-T}

O fragmento Vac1AA amplificado após purificação foi clonado no plasmídeo pGEMT. A ligação entre pGEM e Vac1AA foi utilizada para transformar células de E. coli Top10. Os plasmídeos de dez colônias brancas da ligação pGEMVac1AA foram extraídos e submetidos à reação de clivagem com a enzima ApaI e a digestão foi analisada em gel de agarose a $2 \%$ (Figura 14).
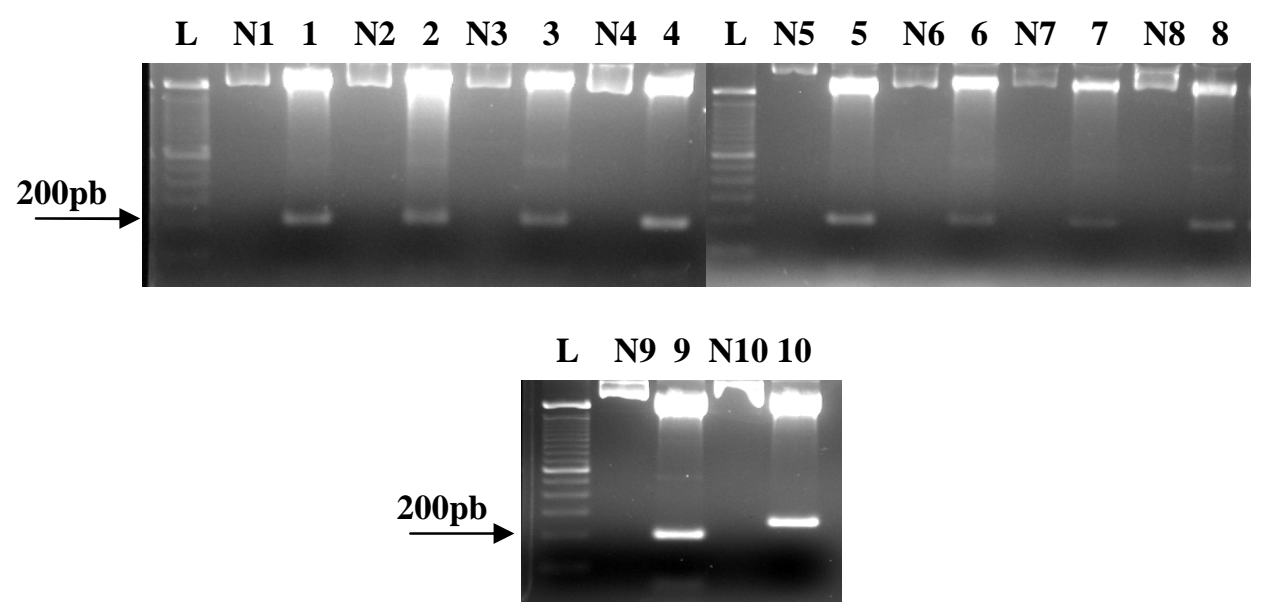

Figura 14: Digestão dos clones pGEMVac1AA. Digestão dos clones pGEMVac1AA_1-10 com a enzima ApaI. L-marcador de 100pb, N1 ao N10-pGEMVac1AA_1 ao 10 não digerido, 1 ao 10-pGEMVac1AA_1 ao 10 digerido com a enzima ApaI.

A reação de clivagem revelou que todos os clones apresentavam o fragmento Vac1AA pela presença de um fragmento de aproximadamente 200pb (202pb). Seis clones foram seqüenciados utilizando-se o oligonucleotídeo T7 para confirmar a presença do fragmento Vac1AA e sua sequiência e um dos clones, pGEMVac1AA_3 (Figura 15), apresentou seqüência correta e foi selecionado para ser utilizado como molde nas construções dos fragmentos Vac1AA, Vac1PA e Vac2. 


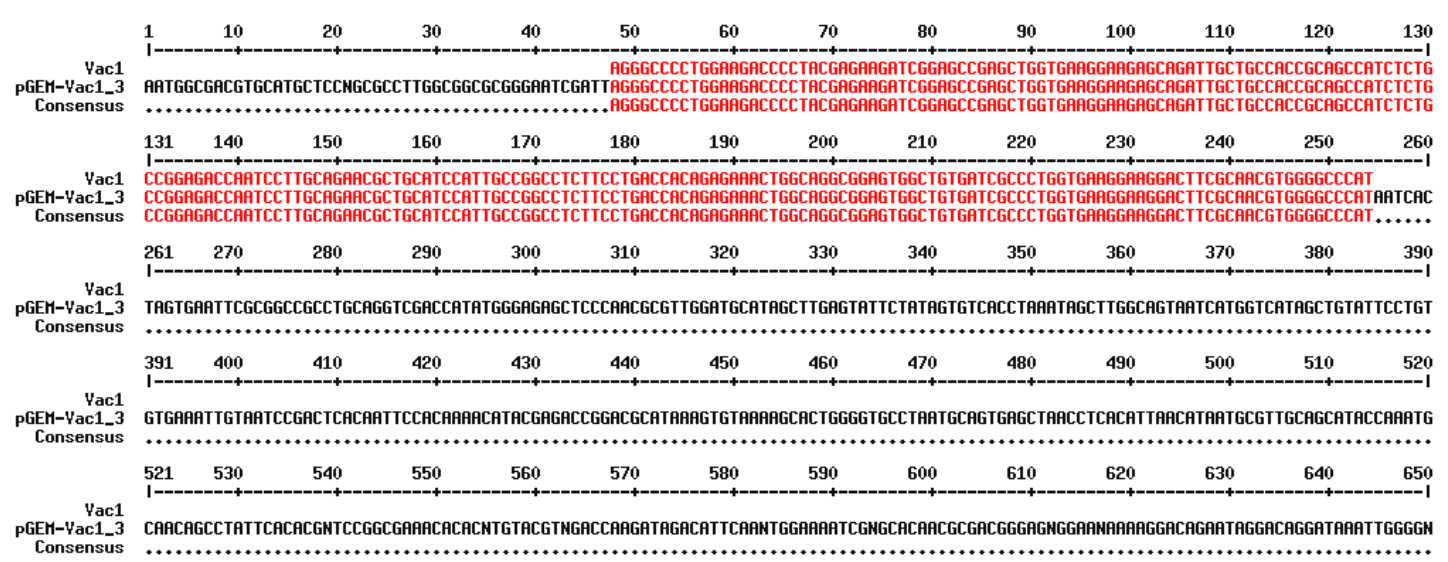

Figura 15:Alinhamento da Vac1AA com o clone pGEMVac1AA_3. Clone pGEMVac1AA seqüenciado com o primer T7.

\subsection{Construcão da vacina pVAXgDVac1AA}

\subsubsection{Obtenção do fragmento Vac1AA}

O clone pGEMVac1AA_3 foi utilizado na reação de clivagem com a enzima ApaI para retirada do fragmento Vac1AA para posterior clonagem no vetor pRE4 clivado com a mesma enzima. A digestão foi analisada em gel de agarose a 1\% (Figura 16).

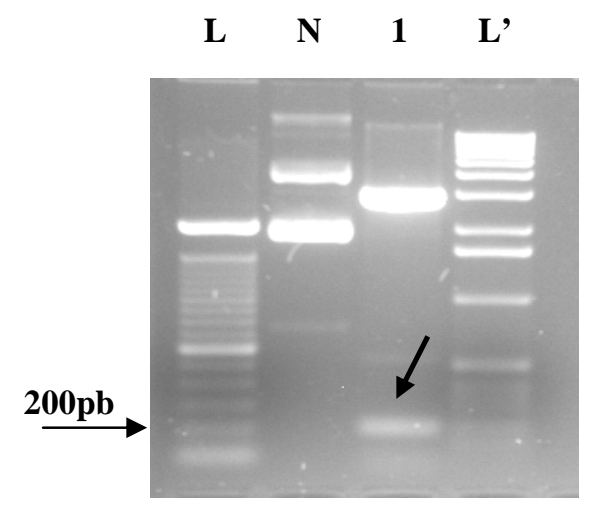

Figura 16: Digestão do clone pGEMVac1AA_3 com a enzima ApaI. L-Marcador de 100pb, NpGEMVac1AA_3 não digerido, 1-pGEMVac1AA_3 digerido com ApaI e L'-Marcador de 1Kb.

O clone pGEMVac1AA_3 liberou o fragmento Vac1AA (198pb) que foi purificado e clonado no vetor pRE4. 


\subsubsection{Construção do fragmento gDVac1AA}

\subsubsection{Clivagem do vetor pRE4}

$\mathrm{O}$ vetor pRE4 foi digerido com a enzima ApaI que lineariza esse plasmídeo para posterior clonagem do fragmento Vac1AA. A digestão foi analisada em gel de agarose a $1 \%$ (Figura 17).

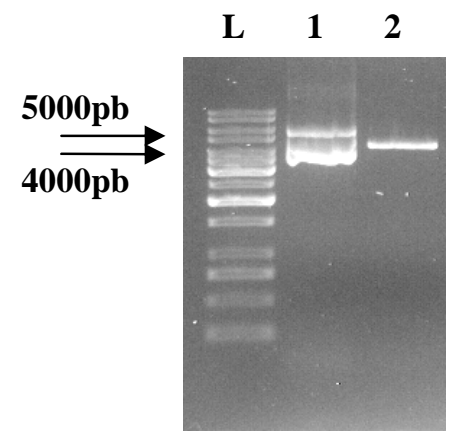

Figura 17: Digestão do vetor pRE4 com a enzima ApaI. L-marcador de $1 \mathrm{~Kb}$ (Fermentas), 1-pRE4 não digerido, 2-pRE4 digerido com ApaI, linearização do vetor.

O vetor foi linearizado, como visto pela banda única de tamanho entre 4000-5000pb (pRE4-4500pb) pela clivagem com a enzima ApaI que digere no interior da gD presente nesse plasmídeo, em seguida, foi desfosforilado e purificado para clonagem do fragmento Vac1AA dentro da seqüência do gene da gD.

\subsubsection{Construção do vetor pRE4Vac1AA}

O fragmento Vac1AA clivado com a enzima ApaI foi clonado no vetor pRE4 clivado com a mesma enzima e a ligação foi utilizada na transformação de células de E. coli Top10.

Plasmídeos de quatro colônias da ligação entre pRE4 e Vac1AA foram extraídos e submetidos à digestão com a enzima $A p a \mathrm{I}$ para verificação da presença do inserto Vac1AA. A reação de clivagem foi analisada em gel de agarose a 1\% (Figura 18). 


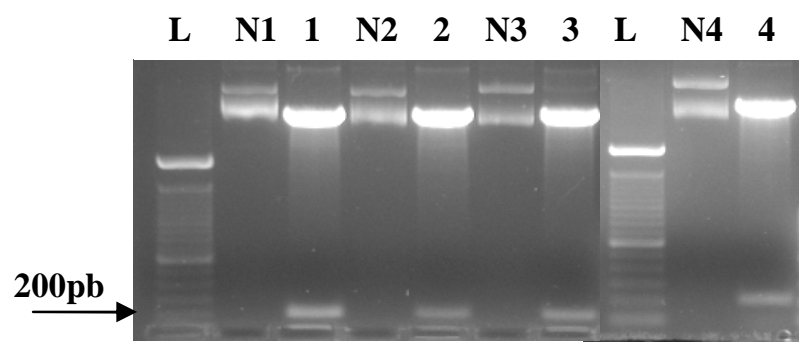

Figura 18: Digestão dos clones pRE4Vac1AA. Digestão dos clones pRE4Vac1AA_1 a 4 com a enzima ApaI. L-marcador de 100pb, N1 ao N4-pRE4Vac1AA_1 a 4 não digerido, 1 ao 4-pRE4Vac1AA_1 a 4 digerido com ApaI.

Os quatro clones apresentaram o fragmento Vac1AA verificado no gel pela banda de tamanho próximo a 200pb (202pb). No entanto, esse fragmento por ser clivado apenas com uma enzima (ApaI) poderia se inserir na direção correta ou invertida e poderia entrar mais de um fragmento no interior da $\mathrm{gD}$, por isso além da reação de clivagem foi realizada duas PCRs.

Em uma das reações utilizou-se os oligonucleotídeos FgDApa e R2Apa(curto) no qual o primer FgDApa hibridiza dentro da gD próximo ao sítio ApaI e R2Apa(curto) no final do inserto ocorrendo amplificação apenas se o inserto estiver na posição correta (Figura 19A), pois se estiver invertido os dois oligonucleotídeos funcionam na mesma direção. A segunda reação foi realizada com os oligonucleotídeos FgDApa e RgDApa ambos anelam dentro da gD próximo ao sítio ApaI, um sendo sense e o outro antisense, respectivamente, dessa forma, é possível verificar a quantidade de fragmentos Vac1AA que se ligaram no interior da gD (Figura 19B). As PCRs foram analisadas em gel de agarose a $2 \%$. 

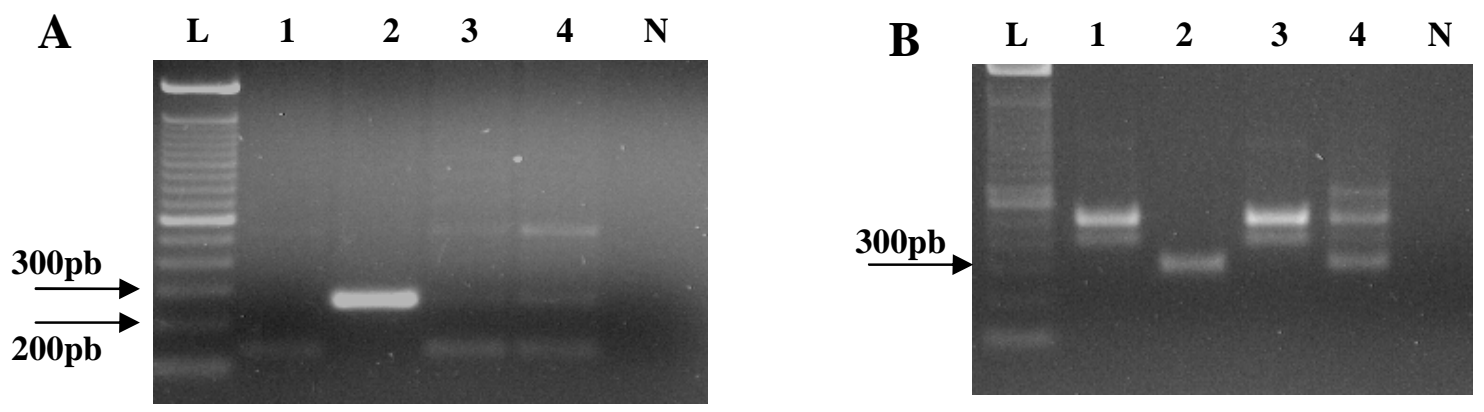

Figura 19: PCR dos clones pREaVac1AA. PCR dos clones pRE4Vac1AA_1 a 4 com os oligonucleotídeos A) FgDApa e R2Apa(curto) e B) FgDApa e RgDApa. L-marcador de 100pb, 1 ao 4-PCR dos clones pRE4Vac1AA_1 a 4, N-negativo.

Apenas o clone pRE4Vac1AA_2 apresentou bandas de amplificação entre 200 e 300pb (262pb) (Figura 19A) e próxima a 300pb (324pb) (Figura 19B) indicando que o fragmento Vac1AA entrou na direção correta e apenas um inserto, respectivamente.

\subsubsection{Obtenção do fragmento gDVac1AA}

O clone pRE4Vac1AA_2 foi utilizado para retirada do fragmento gDVac1AA pela clivagem com a enzima HindIII que flanqueia o gene da gD. A clivagem foi analisada em gel de agarose a $1 \%$ (Figura 20).

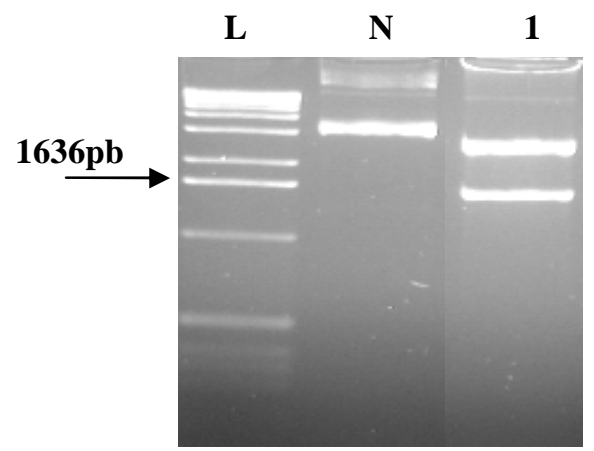

Figura 20: Clivagem do clone pRE4Vac1AA_2 com a enzima HindIII. L-marcador de 1Kb, NpRE4Vac1AA_2 não digerido e 1-pRE4Vac1AA_2-digerido com a enzima HindIII.

O fragmento gDVac1AA liberado do clone pVAXgDVac1AA_2 apresentou tamanho próximo a 1636pb (1621pb), foi purificado e usado na clonagem com o vetor $\mathrm{pVAX}$. 


\subsubsection{Clonagem do fragmento gDVac1AA no vetor pVAX}

O fragmento gDVac1AA foi clonado no plasmídeo pVAX clivado também com a enzima HindIII (item 5.1.2) por meio de uma reação de ligação que foi utilizada na transformação de células de E. coli Top10. A seleção do plasmídeo recombinante pVAXgDVac1AA foi feita inicialmente por duas PCRs de 5 grupos contendo 5 colônias cada. A primeira reação foi realizada com os oligonucleotídeos T7 e RgDApa (Figura 21A), que indica a direção do fragmento gDVac1AA no interior do $\mathrm{pVAX}$, pois o primer $\mathrm{T} 7$ hibridiza no pVAX e o RgDApa dentro da gD próximo ao sítio ApaI, se o fragmento estiver na posição correta ocorre à amplificação; a segunda reação foi realizada com os oligonucleotídeos T7 e BGH (Figura 21B) ambos anelam no pVAX, um sendo sense e o outro antisense, respectivamente, dessa forma, é possível verificar a quantidade de fragmentos gDVac1AA que se ligaram no interior do vetor. As PCRs foram analisadas em gel de agarose a $1 \%$.
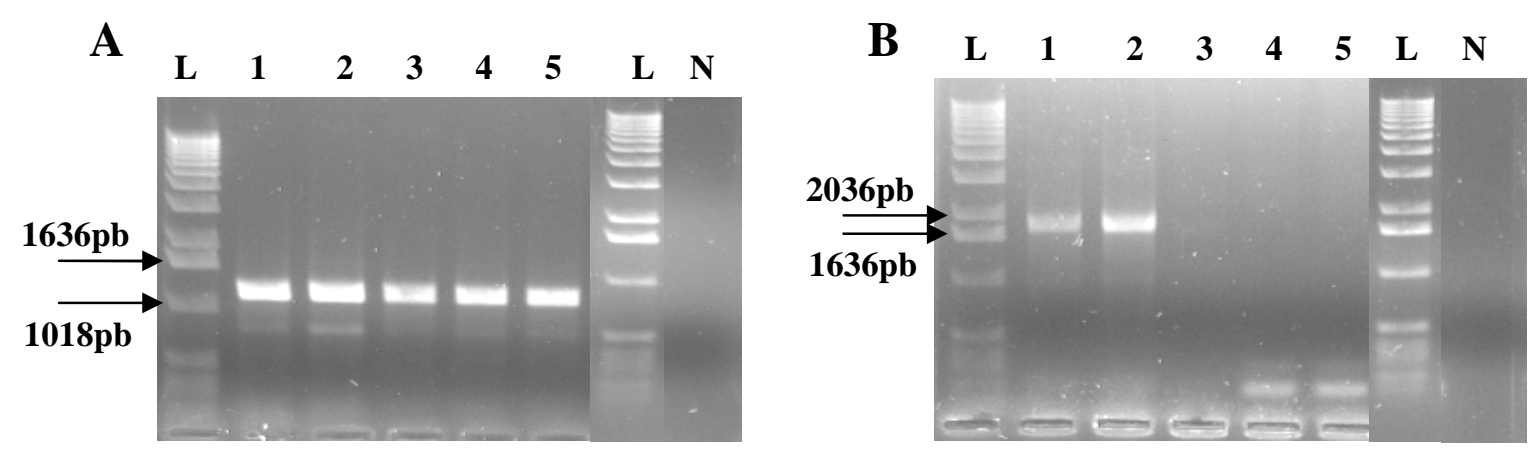

Figura 21: PCR de colônia da ligação entre pVAX e gDVac1AA. PCR de 5 grupos de colônias da ligação entre pVAX e gDVac1AA com os oligonucleotídeos A) T7 e RgDApa e B) T7 e BGH. L-marcador de $1 \mathrm{~Kb}, 1$ ao 5-PCR dos 5 grupos, N-negativo.

Os 5 grupos de colônias apresentaram o fragmento gDVac1AA na direção correta demonstrada no gel pelo fragmento de tamanho entre 1018-1636pb (1188pb) (Figura 21A), no entanto, apenas os grupos 1 e 2 apresentam apenas um inserto gDVac1AA representado no gel pelo fragmento de tamanho entre 1636-2036pb (1798pb) (Figura 21B). A partir dos resultados acima, foi realizada nova PCR dos grupos 1 e 2, que apresentaram fragmentos de amplificação do tamanho esperado. 
A reação foi realizada com os oligonucleotideos T7/R2Apa(curto) e F1Apa (curto)/BGH (Figura 22) que identificam a presença do fragmento Vac1AA e sua direção, pois os oligonucleotídeos $\mathrm{T} 7$ e BGH anelam no pVAX enquanto os primers R2Apa(curto) e F1Apa(curto) hibridizam no final e início do fragmento Vac1AA, respectivamente. Novamente os resultados foram analisados em gel de agarose a $1 \%$.

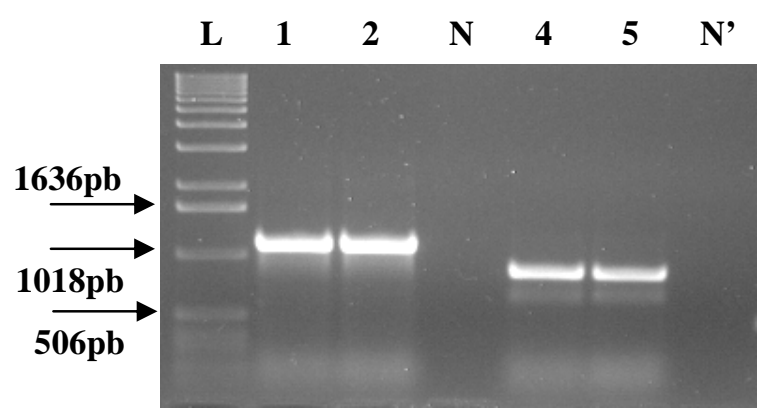

Figura 22: PCR de colônia da ligação entre pVAX e gDVac1AA. PCR dos grupos 1 e 2 de colônias da ligação entre pVAX e gDVac1AA com os oligonucleotídeos T7 e R2Apa(curto), canaletas 1-grupo 1, 2-grupo 2 e N-negativo; oligonucleotídeos F1 Apa(curto) e BGH, canaletas 4-grupo 1, 5-grupo 2 e N'-negativo; L-marcador de $1 \mathrm{~Kb}$.

Ambos os grupos 1 e 2 indicaram a presença da Vac1AA na direção correta devido aos fragmentos de tamanho entre 1018-1636pb (1126pb) para os oligonucleotídeos T7 e R2Apa(curto) e entre 506-1018pb (876pb) para F1Apa(curto) e BGH.

A partir desses resultados, foi feito uma nova PCR com os plasmídeos das dez colônias dos grupos 1 e 2. Para cada plasmídeo foi realizado três PCRs, uma utilizando os oligonucleotídeos T7 e BGH (Figura 23A), outra com T7 e RgDApa (Figura 23B) e a última com T7 e R2Apa(curto) (Figura 23C). O produto das PCRs foi analisado em gel de agarose a $1 \%$. 

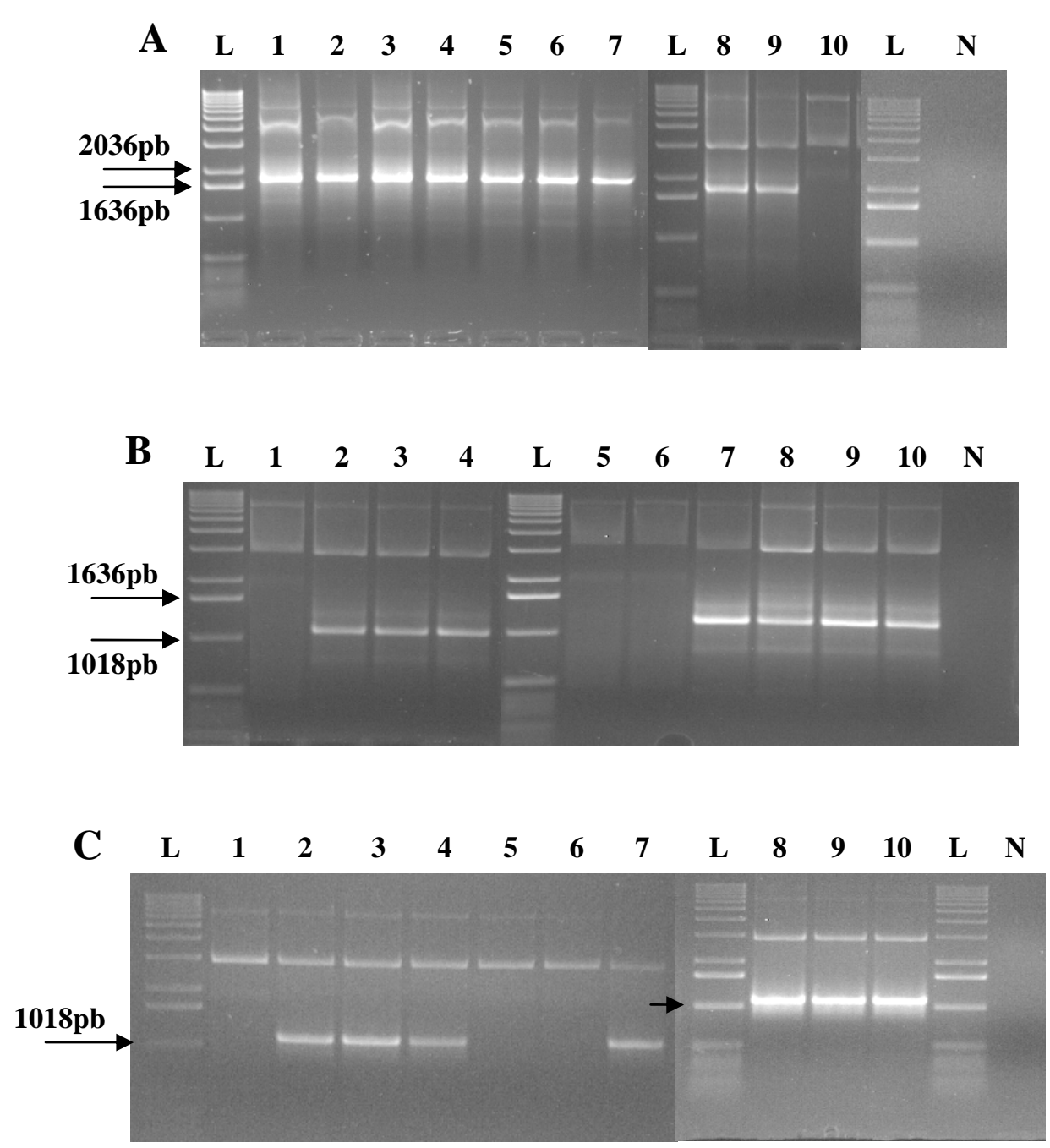

Figura 23: PCR dos clones pVAXgDVac1AA. PCR dos 10 clones extraídos dos grupos 1 e 2 de colônias da ligação entre pVAX e gDVac1AA com os oligonucleotídeos A) T7 e BGH, B) T7 e RgDApa e C) T7 e R2Apa(curto). L-marcador de 1Kb, 1 a 10-clones pVAXgDVac1AA_1 ao 10 e N-negativo.

Os clones pVAXgDVac1AA_1 a 9 apresentaram fragmento de amplificação entre 1636-2036pb (1798pb) com os oligonucleotídeos T7 e BGH (Figura 23A), indicando a entrada de apenas um inserto gDVac1AA; os clones pVAXgDVac1AA_2, 3, 4, 7, 8, 9 e 10 apresentaram fragmento de amplificação entre 1018-1636pb (1188pb) com os primers T7 e RgDApa (Figura 23B), indicando a entrada do fragmento na direção correta e esses mesmos clones também apresentaram fragmento de amplificação próximo a 1018pb (1126pb) com T7 e R2Apa(curto) (figura 23C), indicando a presença da Vac1AA na direção correta no interior da $g D$. 
Além das PCRs, os plasmídeos extraídos das dez colônias dos grupos 1 e 2 também foram submetidos a reação de clivagem com as enzimas PvuII e NotI (Figura 24). A digestão foi analisada em gel de agarose a $1 \%$.

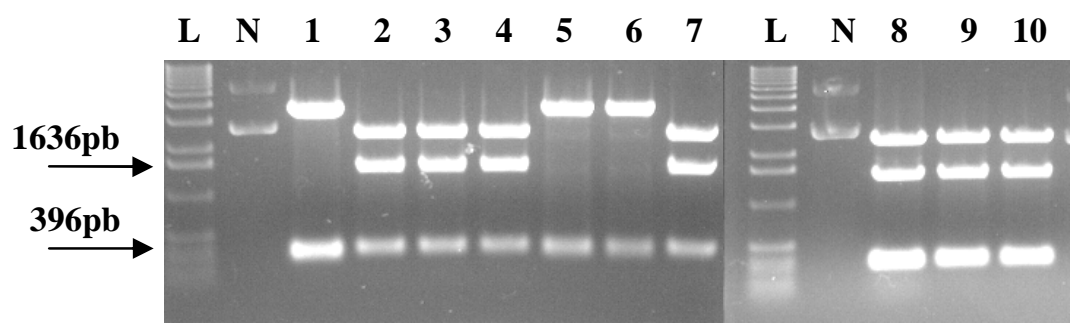

Figura 24: Clivagem dos clones pVAXgDVac1AA. Clivagem dos clones pVAXgDVac1AA_1 a 10 com as enzimas $P v u I$ e $N o t I$. L-marcador de $1 \mathrm{~Kb}, \mathrm{~N}$-não digerido, 1 a 10-clones pVAXgDVac1AA_1 ao 10 digeridos com PvuII e NotI.

Os clones pVAXgDVac1AA_2, 3, 4, 7, 8, 9 e 10 apresentaram fragmento de tamanho próximo a 1636pb (1461pb) após a clivagem com PvuII e NotI indicando a presença do fragmento gDVac1AA na direção correta no interior do pVAX. Uma banda próxima a 396pb está presente em todos os clones, assim como ocorreu para os clones pVAXgD, o que confirma que a enzima $P v u I I$ deve digerir em algum sítio não específico no interior do vetor pVAX.

A partir dos resultados obtidos com as PCRs e a análise de restrição, dois plasmídeos recombinantes, pVAXgDVac1AA_3 e 7, foram analisados por seqüenciamento utilizando-se os oligonucleotídeos T7, BGH e FgDApaseq para confirmação da sequiência e o clone pVAXgDVac1AA_7 (Figuras 25) foi selecionado para utilização nos ensaios in vitro e in vivo. 

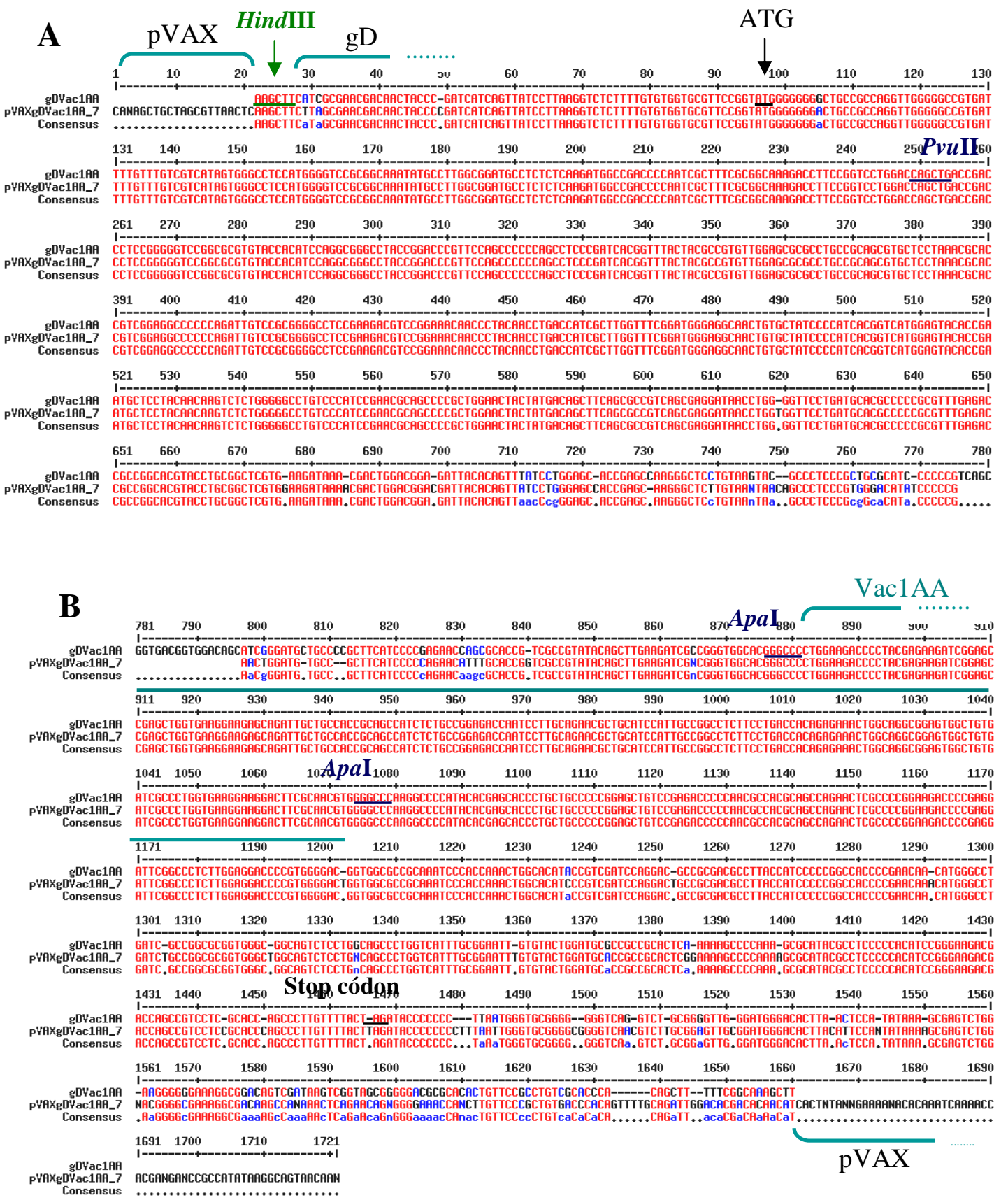

Figura 25: Alinhamento do fragmento gDVac1AA com o clone pVAXgDVac1AA_7. A) gDVac1AA alinhada com o clone pVAXgDVac1AA_7 seqüenciado com o primer T7, em destaque o sítio da enzima HindIII utilizada na retirada do fragmento, o inicio do gene da $\mathrm{gD}$, o primeiro códon a ser traduzido em proteína (ATG) e o sítio da enzima $P v u I I$. B) gDVac1AA alinhada com o clone pVAXgDVac1AA_7 seqüenciado com o primer FgDApaseq, em destaque os sítios da enzima ApaI, a seqüência da Vac1AA, o códon de terminação da tradução da proteína $\mathrm{gD}(\mathrm{TAG})$ e o final do gene da $\mathrm{gD}$.

A partir do seqüenciamento foi possível visualizar o inicio (Figura 25A) e o fim (Figura 25B) do fragmento gDVac1AA, confirmando a presença de um único fragmento na 
direção correta no interior do vetor $\mathrm{pVAX}$ e a presença de um único fragmento Vac1AA (Figura 25B) no interior da gD.

\subsection{Construcão da vacina pVAXgDVac1PA}

\subsubsection{Obtenção do fragmento Vac1PA}

Após o seqüenciamento dos seis clones pGEMVac1AA (item 5.3) o clone pGEMVac1AA_3 foi selecionado para ser utilizado como molde na construção do fragmento Vac1PA. Esse fragmento foi obtido por uma reação de amplificação utilizando-se os oligonucleotídeos F1Pvu e R2Apa(curto) (Figura 26) que inserem no fragmento os sítios das enzimas $P v u \mathrm{II}$ e $A p a \mathrm{I}$, respectivamente. O produto da PCR foi analisado em gel de agarose a $2 \%$.

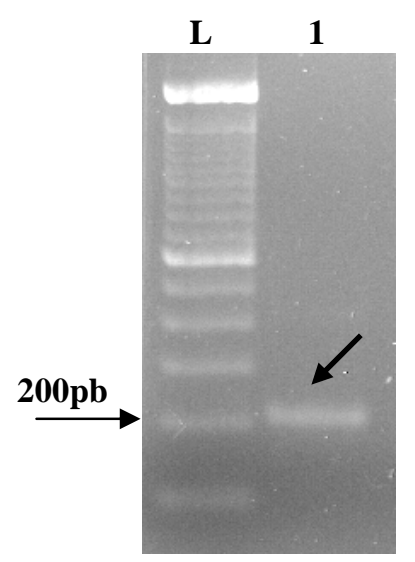

Figura 26: Amplificação da Vac1PA. Vac1PA apresenta os sítios das enzimas $P v u I I$ no 5 ' e ApaI na extremidade 3'. L-marcador de 100pb, 1-Vac1PA amplificada.

O fragmento Vac1PA (208pb) foi amplificado, purificado e digerido com as enzimas $P v u \mathrm{II}$ e $A p a \mathrm{I}$ para clonagem no interior da $\mathrm{gD}$ presente no vetor $\mathrm{pRE} 4$ clivado com as mesmas enzimas. 


\subsubsection{Construção do fragmento gDVac1PA}

\subsubsection{Clivagem do vetor pRE4}

$\mathrm{O}$ vetor pRE4 foi digerido com as enzimas $P v u \mathrm{II}$ e $A p a \mathrm{I}$ para clonagem do fragmento Vac1PA. A digestão foi analisada em gel de agarose a 1\% (Figura 27).

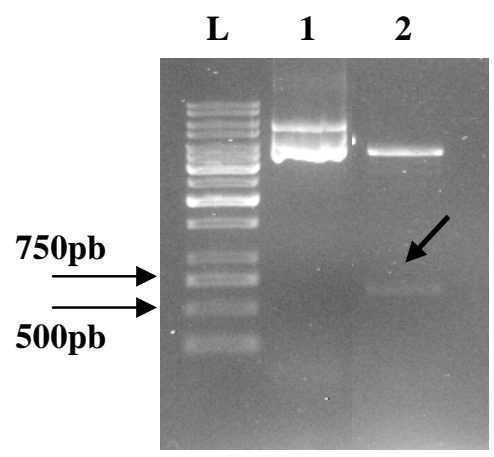

Figura 27: Digestão do vetor pRE4 com as enzimas PvuII e ApaI. L-marcador de 1Kb (Fermentas), 1-pRE4 não digerido, 2-pRE4 digerido com $P v u \mathrm{II}$ e $A p a \mathrm{I}$, retirada de um fragmento da $\mathrm{gD}$.

O vetor foi clivado com as enzimas $P v u I I$ e $A p a I$ retirando um fragmento de $646 \mathrm{pb}$ do interior da $\mathrm{gD}$. $\mathrm{O}$ vetor $\mathrm{pRE} 4$ sem esse fragmento da $\mathrm{gD}$ foi purificado para clonagem com $\mathrm{o}$ fragmento Vac1PA.

\subsubsection{Construção do vetor pRE4Vac1PA}

O fragmento Vac1PA e o vetor pRE4 clivados com as enzimas PvuII e ApaI foram ligados e a mistura da ligação foi utilizada na transformação de células de E. coli Top10. Plasmídeos de dez colônias da ligação entre pRE4 e Vac1PA foram extraídos e submetidos a PCR utilizando-se os oligonucleotídeos FgDPvu e R2Apa(curto), o primeiro primer hibridiza no interior da gD próximo ao sítio da enzima $P v u \mathrm{II}$ e o R2Apa(curto) no final do fragmento Vac1PA. O produto da reação de PCR foi analisado em gel de agarose a 1\% (Figura 28). 


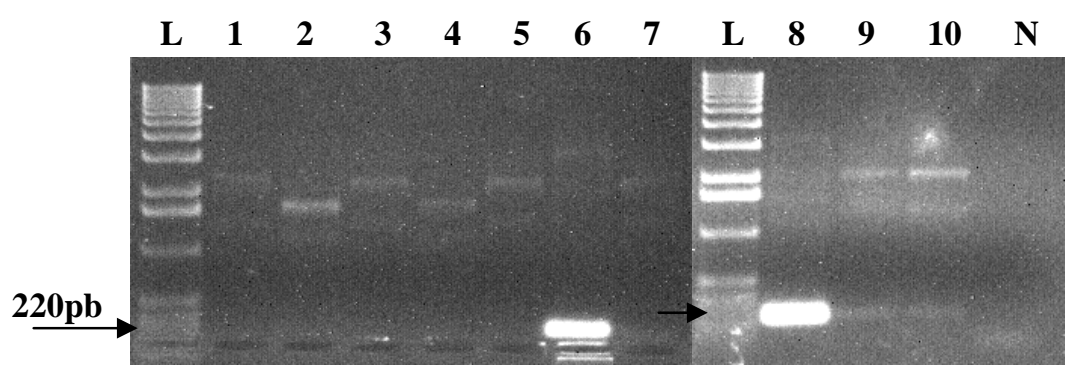

Figura 28: PCR dos clones pRE4Vac1PA. PCR de 10 clones da ligação entre pRE4 e Vac1PA. L-marcador de $1 \mathrm{~Kb}, 1$ a 10-clones pRE4Vac1PA_1 ao 10 e N-negativo.

Os clones pRE4Vac1PA_6 e 8 apresentaram fragmento de tamanho próximo a 220pb o tamanho esperado para amplificação com os oligonucleotídeos utilizados (246pb).

Plasmídeos de outras sete colônias da ligação entre pRE4 e Vac1PA foram extraídos e submetidos juntamente com os dois clones positivos (pRE4Vac1PA_6 e 8) a reação de clivagem utilizando-se as enzimas $P v u I I$ e $A p a I$. A reação foi analisada em gel de agarose a $1,5 \%$ (Figura 29).

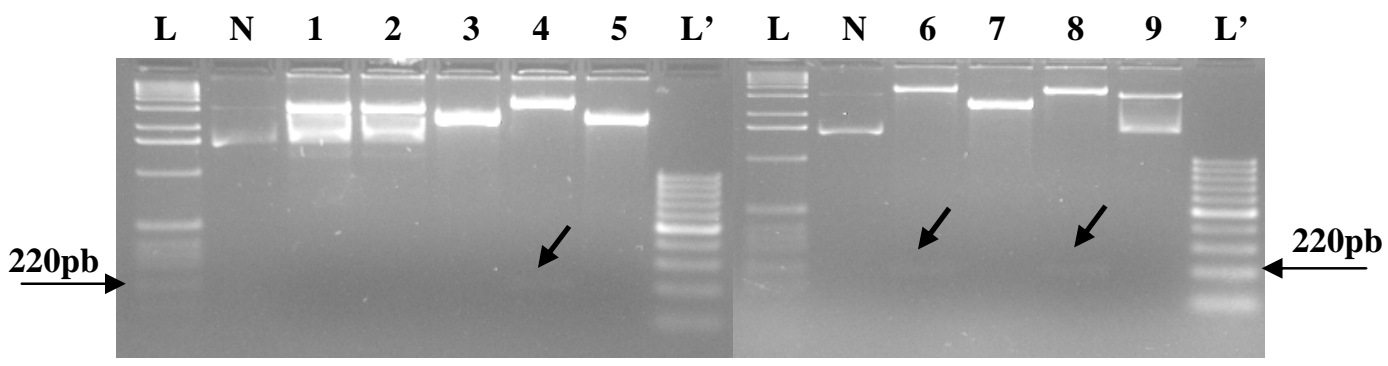

Figura 29: Clivagem dos clones pRE4Vac1PA. Clivagem de 9 clones da ligação entre pRE4 e Vac1PA, incluindo os clones pRE4Vac1PA_6 e 8 positivos na reação de PCR. L-marcador de 1Kb, L'-marcador de 100pb (Fermentas), N-plasmídeo pRE4Vac1PA não digerido e 1 a 9-clones pRE4Vac1PA_1 ao 9 clivados.

Os clones pRE4Vac1PA_4, 6 e 8 apresentaram fragmento de tamanho próximo a 220pb condizente com o tamanho da fragmento Vac1PA de 196pb após clivagem, sendo os clones 6 e 8 já analisados por PCR e confirmando seu resultado.

\subsubsection{Obtenção do fragmento gDVac1PA}

Os plasmídeos pRE4Vac1PA_4, 6 e 8 foram submetidos a duas reações de clivagem uma utilizando-se a enzima HindIII e a outra realizada com a enzima ApaI. A clivagem com a 
enzima HindIII possibilita a retirada de todo o fragmento gDVac1PA, enquanto a enzima ApaI apenas lineariza o vetor o que nos fornece a possibilidade de avaliar se o plasmideo é recombinante pelo tamanho do fragmento gerado. As reações foram analisadas em gel de agarose a 1\% (Figura 30).

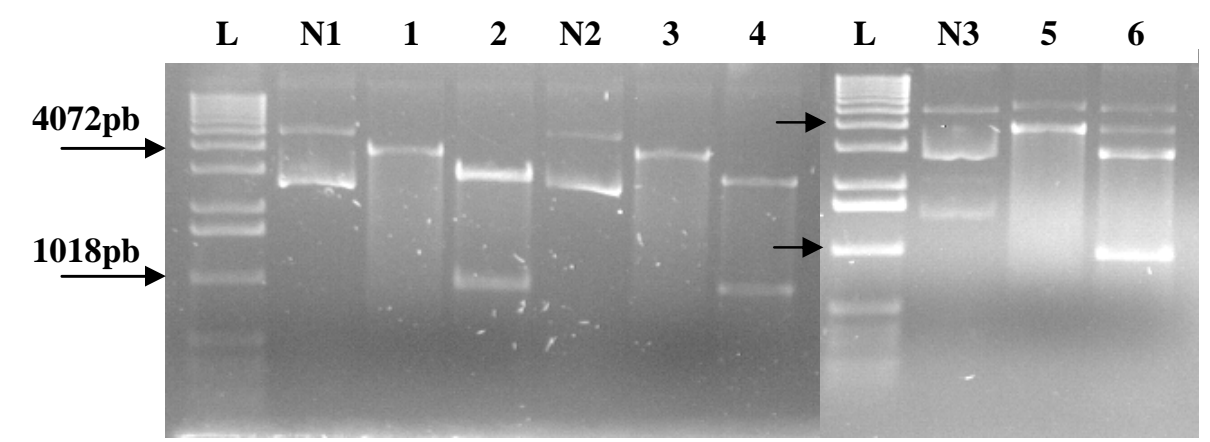

Figura 30: Clivagem dos clones pRE4Vac1PA_4, 6 e 8. L-marcador de 1Kb, N1, N2 e N3-pRE4Vac1PA_4, 6 e 8 não digerido, respectivamente; 1, 3, e 5-pRE4Vac1PA_4, 6 e 8 digeridos com ApaI e 2, 4 e 6pRE4Vac1PA_4, 6 e 8 clivados com HindIII.

Os três clones pRE4Vac1PA_4, 6 e 8 apresentaram fragmentos do tamanho próximo a 4072pb (4050pb) quando clivado com a enzima ApaI e liberaram um fragmento de aproximadamente 1018pb (973pb) quando digeridos com HindIII, o que confirma que os três eram recombinantes para o fragmento gDVac1PA.

O fragmento gDVac1PA foi recuperado do clone pRE4Vac1PA_8 digerido com a enzima HindIII, purificado e utilizado na clonagem do vetor pVAX.

\subsubsection{Clonagem do fragmento gDVac1PA no vetor pVAX}

O pVAX foi digerido com a enzima HindIII como demonstrado no item 5.1.2 e utilizado na construção da vacina pVAXgDVac1PA. O fragmento gDVac1PA foi ligado no plasmídeo pVAX e a mistura de ligação utilizada na transformação de células de $E$. coli Top10.

A seleção do plasmídeo recombinante pVAXgDVac1PA foi feita inicialmente por PCR de 5 grupos contendo 5 colônias cada com os oligonucleotídeos T7 e RgDApa (Figura 
31A), que indica a direção do fragmento no interior do vetor pVAX, e com os oligonucleotídeos T7 e BGH (Figura 31B), que indicam a quantidade de fragmentos gDVac1PA que se ligaram no interior do vetor. O produto das PCRs foi analisado em gel de agarose a $1 \%$.
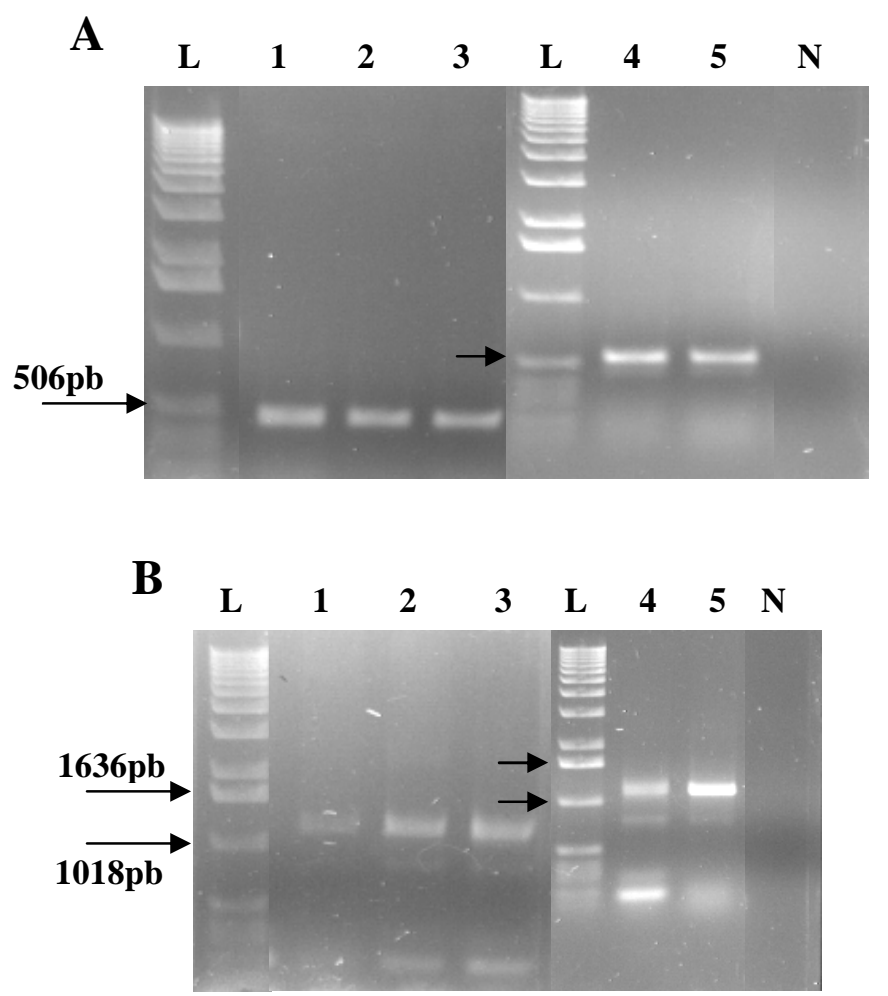

Figura 31: PCR de colônia da ligação entre pVAX e gDVac1PA. PCR de 5 grupos de colônias da ligação entre pVAX e gDVac1PA com os oligonucleotídeos A) T7 e RgDApa e B) T7 e BGH. L-marcador de 1Kb, 1 a 5-PCR dos 5 grupos 6, 7, 8, 9 e 10 e N-negativo.

Os cinco grupos (denominados 6, 7, 8, 9 e 10) apresentaram fragmento próximo a 506pb (540pb) com os primers T7 e RgDApa (Figura 31A), indicando que o inserto gDVac1PA entrou na direção correta, e fragmento de tamanho entre 1018-1636pb (1150pb) com os oligonucleotídeos T7 e BGH (Figura 31B), indicando apenas um inserto.

A partir desses resultados foi feito nova PCR dos grupos 7, 8, 9 e 10 com os oligonucleotideos T7/R2Apa(curto) e FgDPvu/BGH que identificam a presença do fragmento Vac1PA e sua direção e do fragmento gDVac1PA e sua direção, respectivamente. Os resultados foram analisados em gel de agarose a 1\% (Figura 32). 


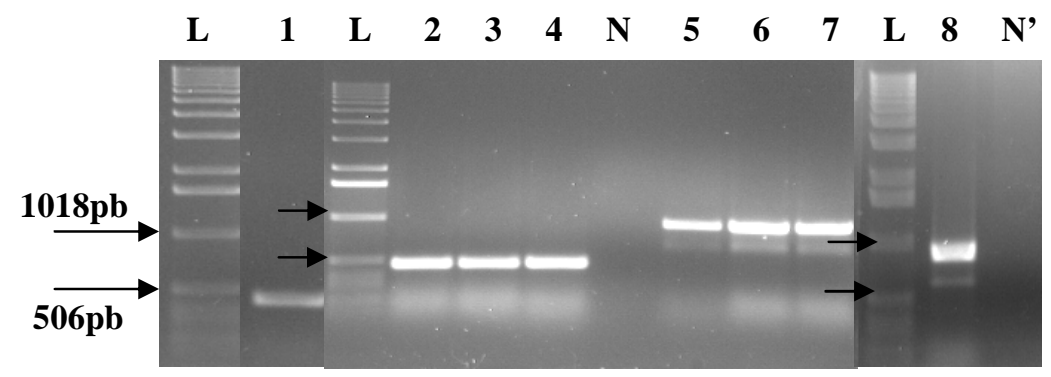

Figura 32: PCR dos grupos 7, 8, 9 e 10 de colônias da ligação entre pVAX e gDVac1PA. Oligonucleotídeos T7/R2Apa(curto), canaletas 1-grupo 7, 2-grupo 8, 3-grupo 9, 4-grupo 10 e N-negativo; oligonucleotídeos FgDPvu/BGH, canaletas 5-grupo 7, 6-grupo 8, 7-grupo 9, 8-grupo 10 e N'-negativo; L-marcador de $1 \mathrm{~Kb}$.

Os quatro grupos $(7,8,9$ e 10) apresentaram fragmentos próximo a 506pb (478pb) com os oligonucleotideos T7 e R2Apa(curto), indicando a presença da Vac1PA na direção correta e fragmento de tamanho entre 506-1018pb (918pb) com os primers FgDPvu e BGH, indicando a presença do inserto gDVac1PA na direção correta.

O plasmídeo de dez colônias dos grupos 7 e 10 foram, então, submetidos separadamente a uma nova PCR utilizando os oligonucleotídeos T7 e BGH (Figura 33A), outra com T7 e RgDApa (Figura 33B) e a última com T7 e R2Apa(curto) (Figura 33C). As reações de PCR foram analisadas em gel de agarose a $1 \%$. 

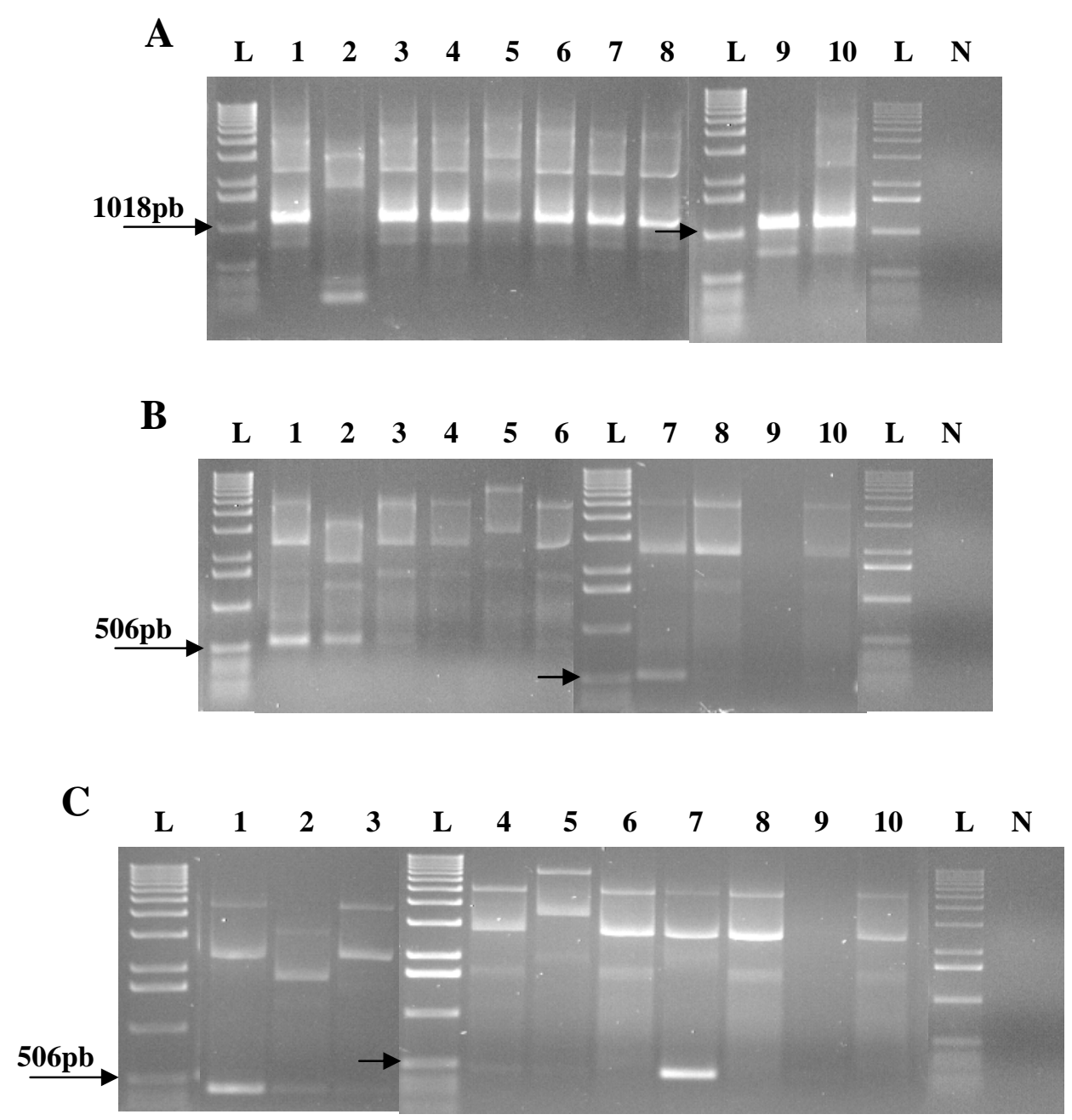

Figura 33: PCR dos clones pVAXgDVac1PA. PCR de 10 clones pVAXgDVac1PA com os oligonucleotídeos A) $\mathrm{T} 7$ e BGH, B) $\mathrm{T} 7$ e RgDApa e C) $\mathrm{T} 7$ e R2Apa(curto). L-marcador de 1Kb, 1 a 10-PCR dos clones pVAXgDVac1PA_11 ao 20 e N-negativo.

Os clones pVAXgDVac1PA_11, 13, 14, 15, 16, 17, 18, 19 e 20 apresentaram fragmento de amplificação próximo a 1018pb (1150pb) com os oligonucleotídeos T7 e BGH (Figura 33A), indicando a entrada de apenas um inserto gDVac1PA; os clones pVAXgDVac1PA_11, 12 e 17 apresentaram fragmento de amplificação próximo a 506pb com os primers T7 e RgDApa (Figura 33B), indicando a entrada do fragmento na direção correta (540pb) e os clones 11 e 17 também apresentaram fragmento de amplificação próximo a 506pb (478pb) com T7 e R2Apa(curto) (Figura 33C), indicando a presença da Vac1AA na direção correta no interior da gD 
Além das PCRs, os plasmídeos extraídos das dez colônias dos grupos 7 e 10 também foram submetidos a reação de clivagem com as enzimas PvuII e NotI (Figura 34). A digestão foi analisada em gel de agarose a $1 \%$.

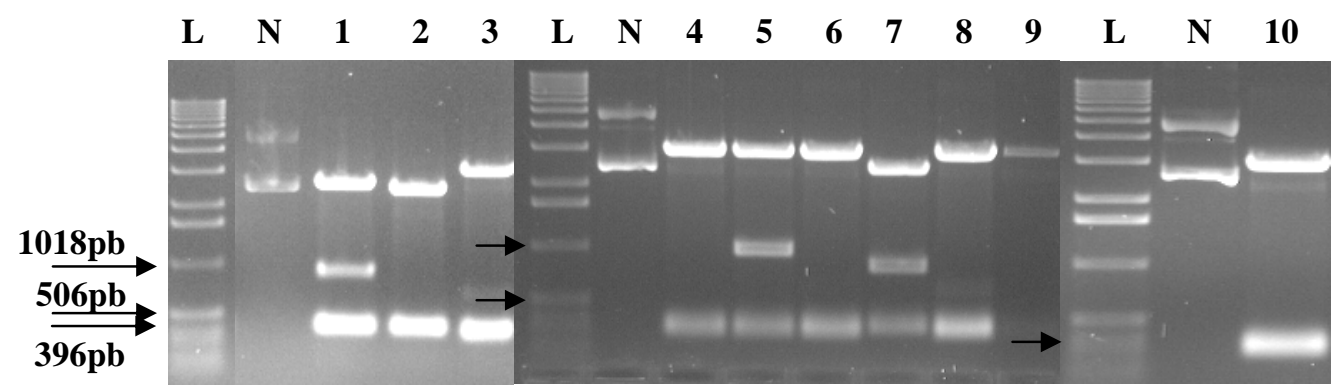

Figura 34: Clivagem dos clones pVAXgDVac1PA. Clivagem dos clones pVAXgDVac1PA_11 a 20 com as enzimas $P v u \mathrm{II}$ e NotI. L-marcador de $1 \mathrm{~Kb}$, N-pVAXgDVac1PA não digerido, 1 a 10-clones pVAXgDVac1PA_11 ao 20 digeridos com PvuII e NotI.

Os clones pVAXgDVac1PA_11 e 17 apresentaram fragmento de tamanho entre 5061018pb (813pb) após a clivagem com PvuII e NotI indicando a presença do fragmento gDVac1PA na direção correta no interior do pVAX. Novamente uma banda próxima a 396pb está presente em todos os clones o que confirma que a enzima $P v u I I$ deve estar digerindo em algum sítio não específico no interior do vetor pVAX.

A partir dos resultados obtidos com as PCRs e a análise de restrição, dois plasmídeos recombinantes, pVAXgDVac1PA_11 e 17, foram analisados por seqüenciamento utilizandose os oligonucleotídeos T7, BGH e FgDPvuseq para confirmação da seqüência e o clone pVAXgDVac1PA_11 (Figura 35) foi selecionado para utilização nos ensaios in vitro e in vivo. 

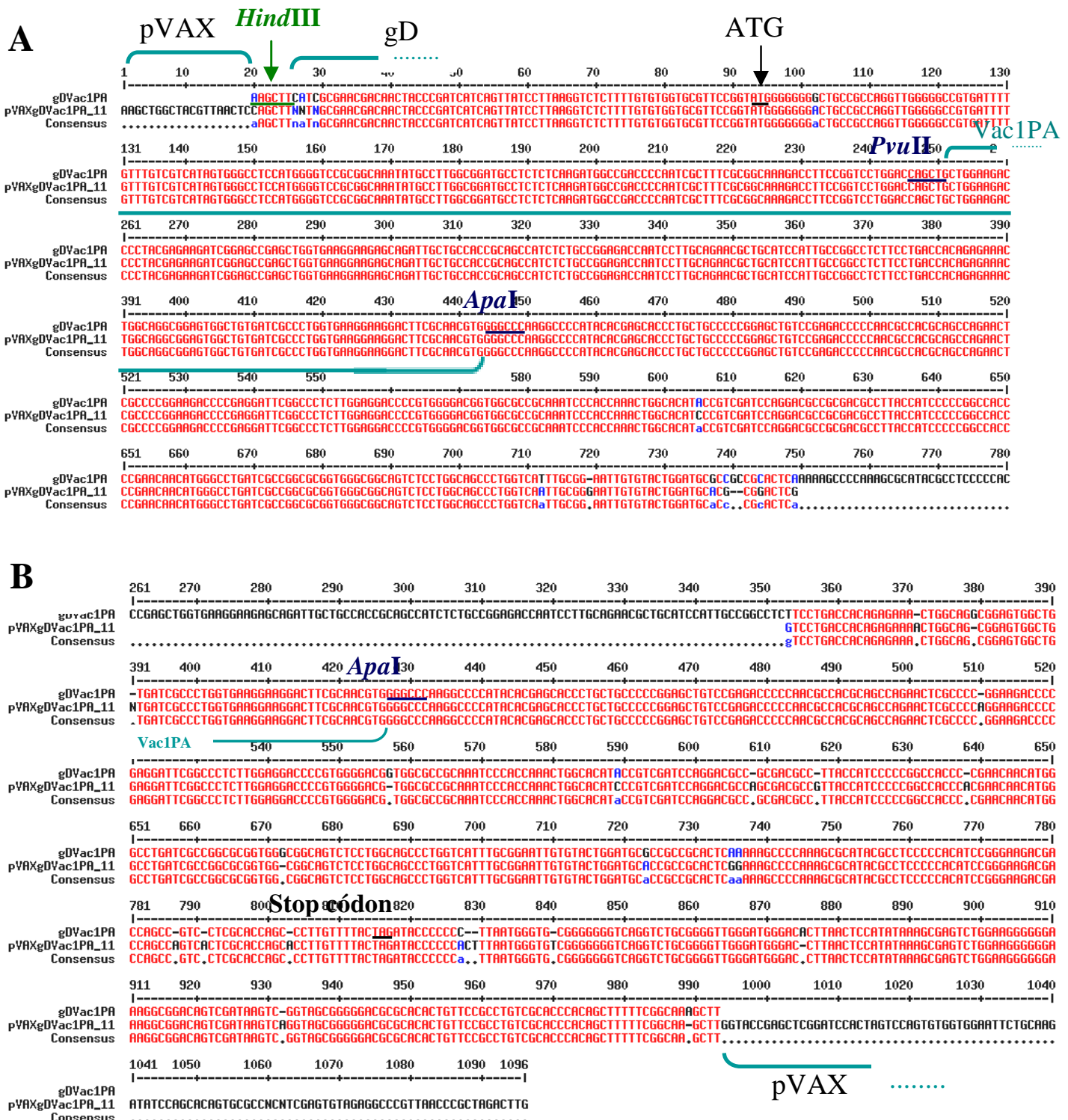

Figura 35: Alinhamento do fragmento gDVac1PA com o clone pVAXgDVac1PA_11. A) gDVac1PA alinhada com o clone pVAXgDVac1PA_11 seqüenciado com o primer $\mathrm{T} 7$, em destaque o sítio da enzima HindIII utilizada na retirada do fragmento, o inicio do gene da gD, o primeiro códon a ser traduzido em proteína (ATG), o sítio da enzima $P v u I I$, o fragmento Vac1PA, o sítio da enzima ApaI no final desse fragmento. B) gDVac1PA alinhada com o clone pVAXgDVac1PA_11 seqüenciado com o primer FgDPvuseq, em destaque o final do fragmento Vac1PA, o sítio da enzima ApaI, o códon de terminação da tradução da proteína gD (TAG) e o final do gene da $\mathrm{gD}$.

A partir do seqüenciamento foi possível visualizar o inicio (Figura 35A) e o fim (Figura 35B) do fragmento gDVac1PA, confirmando a presença de um único fragmento na direção correta no interior do vetor pVAX e a presença de um único fragmento Vac1PA na direção correta (Figura 35A) no interior da gD. 


\section{$\underline{5.6}$ Construcão da vacina pVAXgDVac2}

\subsubsection{Obtenção do fragmento Vac2}

O clone pGEMVac1AA_3 (item 5.3) foi utilizado como molde na construção do fragmento Vac2. Inicialmente foi realizada duas reações de amplificação, uma utilizando-se os oligonucleotideos F1Apa(curto) e R2Bam, inserindo no início do fragmento o sítio da enzima ApaI e no final o sítio da enzima BamHI, o que gerou o fragmento Vac1AB (207pb), e outra reação com os oligonucleotídeos R2Apa(curto) e F1Bam, inserindo os sítios de forma contrária, BamHI no inicio e ApaI no final gerando o fragmento Vac1BA (208pb). O produto das amplificações foi analisado em gel de agarose a 1\% (Figura 36).

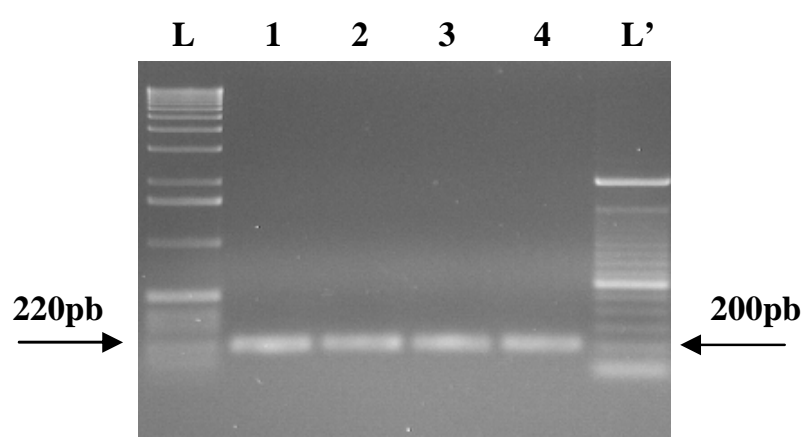

Figura 36: Amplificação das Vac1AB e Vac1BA. Vac1AB e Vac1BA apresentam os sítios das enzimas ApaI e BamHI. L-marcador de 1Kb, L'-marcador de 100pb, 1 e 2-Vac1AB e 3 e 4-Vac1BA amplificadas.

Em seguida, os fragmentos Vac1AB e Vac1BA foram digeridos com a enzima BamHI, purificados e ligados. A ligação foi analisada em gel de agarose a 2\% (Figura 37).

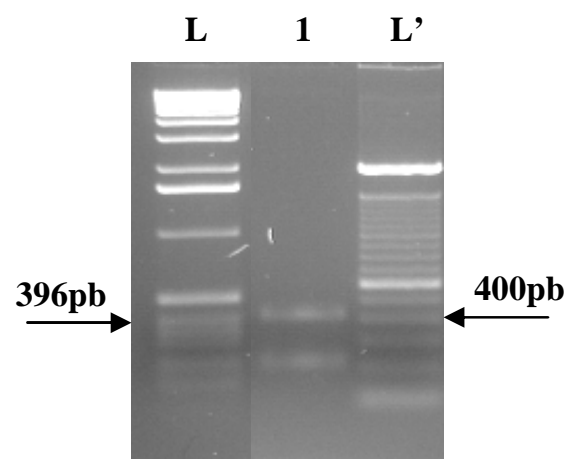

Figura 37: Ligação entre os fragmentos Vac1AB e Vac1BA. L-marcador de 1Kb, L'-marcador de 100pb, 1ligação. 
O fragmento Vac2 de $405 \mathrm{pb}$ foi purificado e digerido com a enzima ApaI para clonagem no vetor pRE4.

\subsubsection{Construção do fragmento gDVac2}

\subsubsection{Construção do vetor pRE4Vac2}

O fragmento Vac2 e o vetor pRE4 clivados com a enzima ApaI (clivagem do vetor pRE4-item 5.4.2.1) foram ligados e a mistura de ligação utilizada na transformação de células de E. coli Top10.

Quinze colônias da ligação entre pRE4 e Vac2 foram submetidas a PCR, utilizando-se os oligonucleotídeos FgDApa e RgDApa (Figura 38A), que indicam a quantidade de fragmento Vac2 no interior da $\mathrm{gD}$, e com os oligonucleotídeos FgDApa e R2Apa(curto) (Figura 38B), que indicam a direção do fragmento Vac2 que se ligou na gD. O produto das PCRs foi analisado em gel de agarose a $1 \%$.
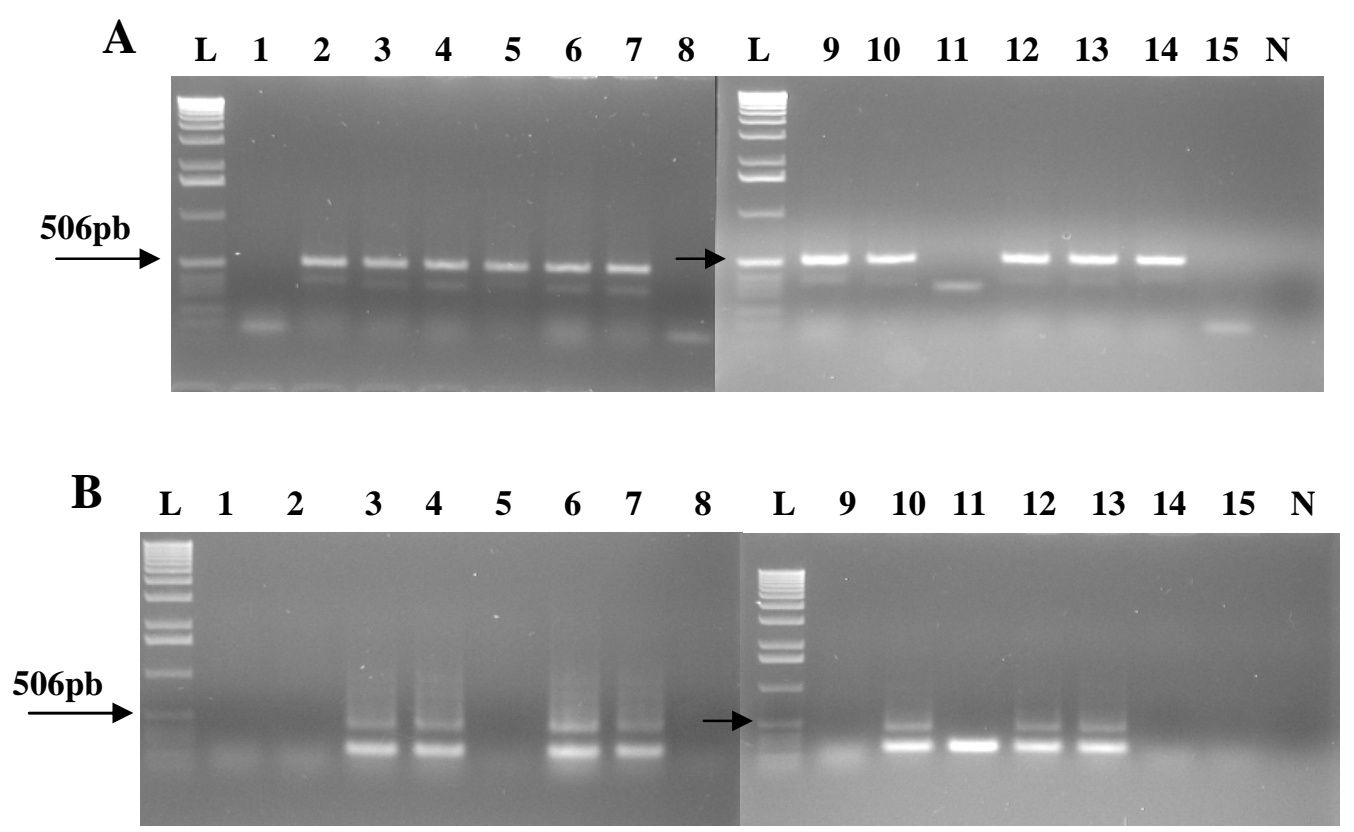

Figura 38: PCR de colônia da ligação entre pRE4 e Vac2. PCR das 15 colônias da ligação entre pRE4 e Vac2 com os oligonucleotídeos A) FgDApa e RgDApa e B) FgDApa e R2Apa(curto). L-marcador de $1 \mathrm{~Kb}, 1$ a 15 PCR das colônias pRE4Vac2_1 ao 15 e N-negativo. 
Os clones pRE4Vac2_2, 3, 4, 5, 6, 7, 9, 10, 12, 13 e 14 apresentaram fragmento de amplificação próximo a 506pb (522pb) com os oligonucleotideos FgDApa e RgDApa, indicando a presença de apenas um inserto Vac2 no interior da gD e os clones pRE4Vac2_3, 4, 6, 7, 10, 12 e 13 apresentaram duas bandas abaixo de 506pb (256 e 460pb**) com os primers FgDApa e R2Apa(curto), indicando direção correta do inserto Vac2 dentro da gD.

**A presença de dois fragmentos ocorre, pois o oligonucleotídeo R2Apa(curto) hibridiza em dois locais no interior da Vac2.

Os plasmídeos das colônias positivas para a presença de apenas um inserto e direção correta foram extraídos e submetidos a reação de clivagem com a enzima ApaI. A digestão foi analisada em gel de agarose a $1 \%$ (Figura 39).

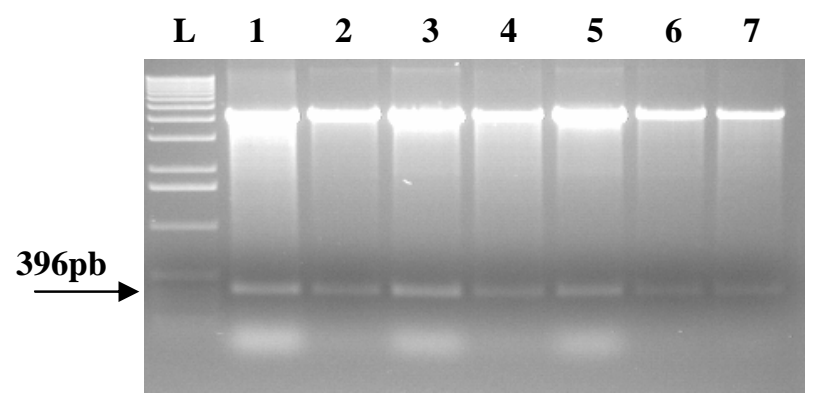

Figura 39: Clivagem dos clones pRE4Vac2. Clivagem de 7 clones da ligação entre pRE4 e Vac2 com a enzima ApaI. L-marcador de 1Kb, 1 a 7-clones pRE4Vac2_3, 4, 6, 7, 10, 12 e 13 digeridos com ApaI.

Todos os clones pRE4Vac2 apresentaram fragmento próximo a 396pb indicando a presença da Vac2 (400pb).

\subsubsection{Obtenção do fragmento gDVac2}

Após as seleções realizadas, o plasmídeo pRE4Vac2_10 foi clivado com a enzima HindIII para a retirada do fragmento gDVac2. A reação foi analisada em gel de agarose a $1 \%$ (Figura 40). 


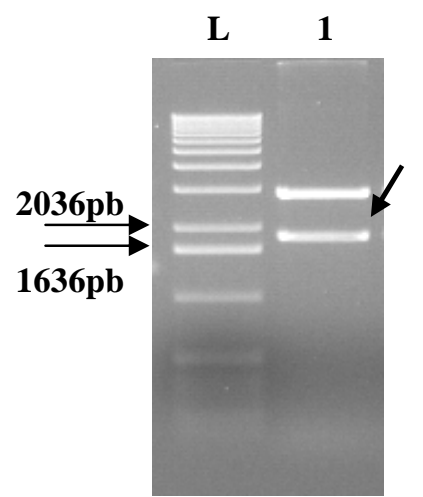

Figura 40: Clivagem do clone pRE4Vac2_10 com a enzima HindIII. L-marcador de 1Kb e 1-pRE4Vac2_10 digerido com HindIII.

O fragmento gDVac2 (1819pb) identificado no gel pela seta foi purificado e clonado no vetor $\mathrm{pVAX}$.

\subsubsection{Clonagem do fragmento gDVac2 no vetor $\mathrm{pVAX}$}

O pVAX digerido com a enzima HindIII (item 5.1.2) foi utilizado na construção da vacina $\mathrm{pVAXgDVac2.} \mathrm{O}$ fragmento gDVac2 foi clonado no plasmídeo $\mathrm{pVAX}$ e a mistura de ligação utilizada na transformação de células de E. coli Top10.

A seleção do plasmídeo recombinante $\mathrm{pVAXgDVac2}$ foi feita inicialmente realizando uma PCR de 10 colônias utilizando-se os oligonucleotídeos T7 e BGH (Figura 41A), que indica a quantidade de fragmentos gDVac2 no interior do pVAX, outra com T7 e RgDApa (Figura 41B), que indica a direção do fragmento no interior do vetor, e a última com T7 e R2Apa(curto) (Figura 41C), que indica a presença da Vac2. O produto das PCRs foi analisado em gel de agarose a $1 \%$. 

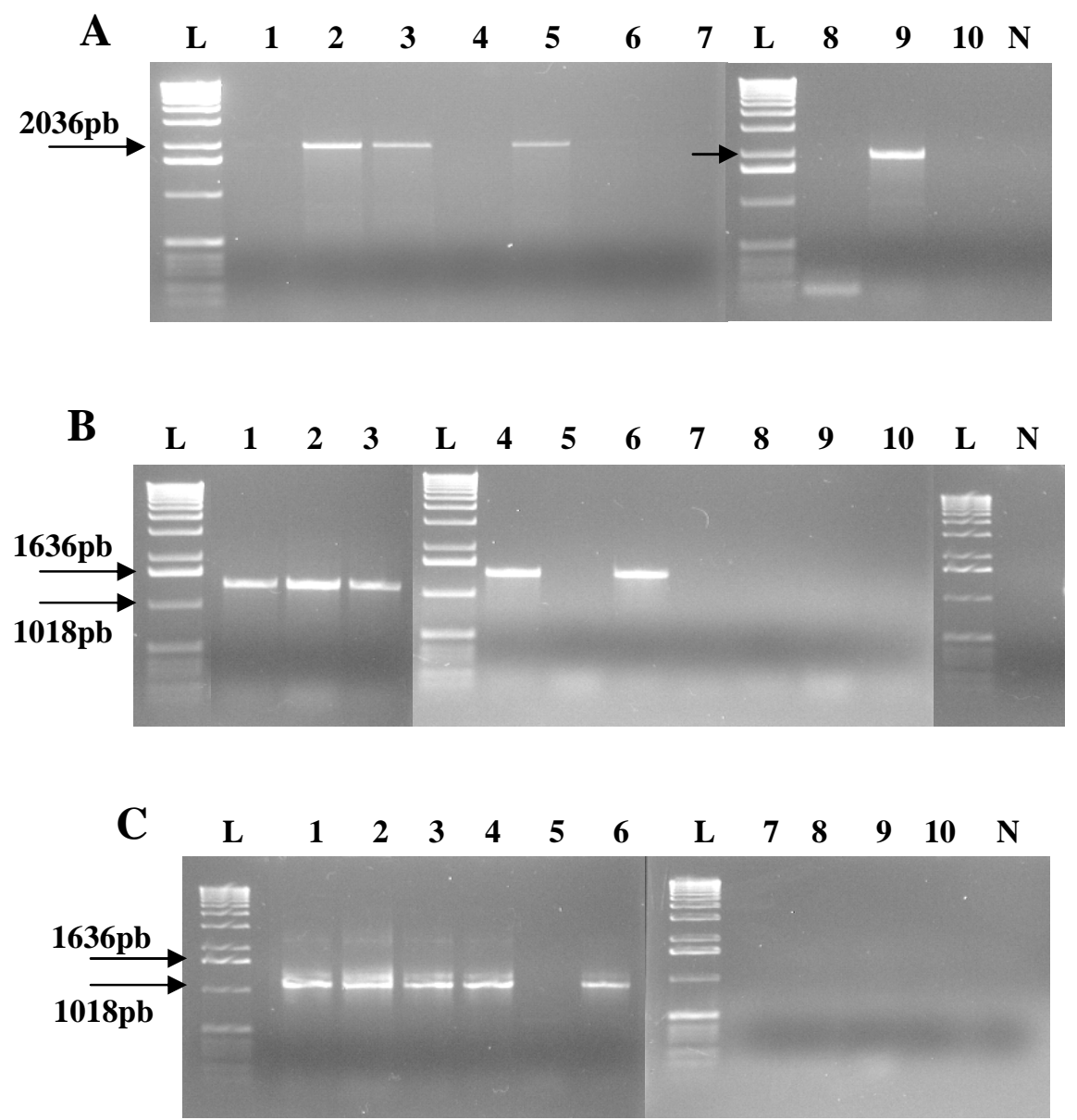

Figura 41: PCR de colônia da ligação entre pVAX e gDVac2. PCR de 10 colônias da ligação entre pVAX e gDVac2 com os oligonucleotídeos A) T7 e BGH, B) T7 e RgDApa e C) T7 e R2Apa(curto). L-marcador de $1 \mathrm{~Kb}, 1$ a 10-PCR das colônias pVAXgDVac2_1 a 10 e N-negativo.

As colônias 2, 3, 5 e 9 apresentaram um fragmento de amplificação próximo a 2072pb (1996pb) com os primers T7 e BGH, indicando apenas um inserto gDVac2 no vetor pVAX; as colônias 1, 2, 3, 4 e 6 apresentaram uma banda de amplificação entre 1018-1636pb (1386pb) com os oligonucleotideos T7 e RgDApa, indicando a direção correta do fragmento gDVac2, e duas bandas entre 1018-1636pb (1120 e 1324pb) com os oligonucleotideos T7 e R2Apa(curto), indicando a presença da Vac2.

Os plasmídeos das colônias pVAXgDVac2_2 e 3 foram extraídos e submetidos a duas reações de clivagem, uma com a enzima BamHI (Figura 42A), que digere no meio da Vac2 e no pVAX, e a outra com a enzima HindIII (Figura 42B) que flanqueia a gDVac2. A digestão foi analisada em gel de agarose a $1 \%$. 

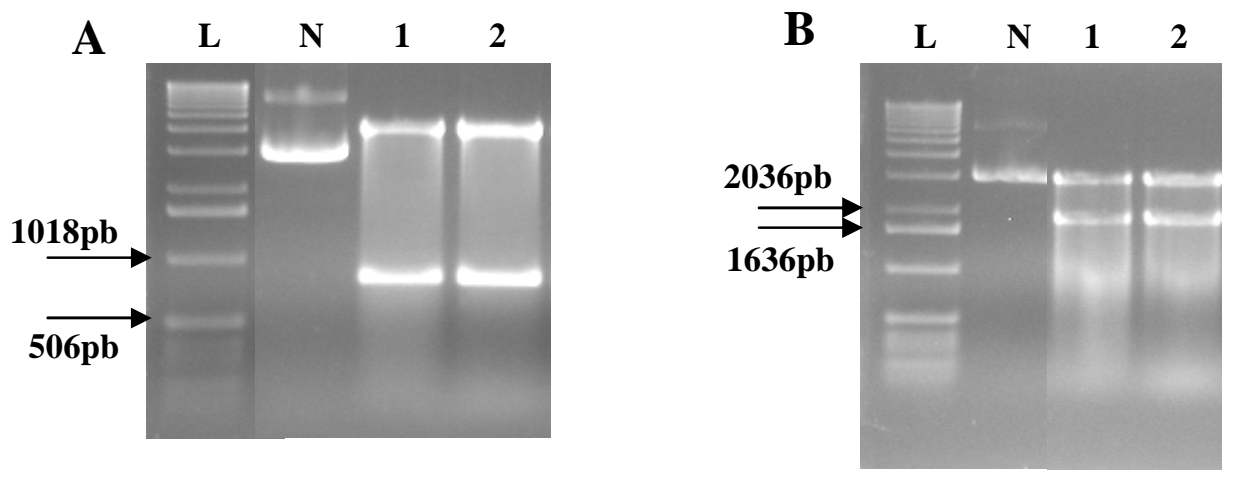

Figura 42: Clivagem dos clones pVAXgDVac2_2 e 3 com a enzima A) BamHI e B) HindIII. L-marcador de $1 \mathrm{~Kb}, \mathrm{~N}-\mathrm{pVAXgDVac} 2$ não digerido e 1 e 2-pVAXgDVac2_2 e 3 digeridos.

Os dois clones apresentaram fragmentos de clivagem entre 506-1018pb (767pb) com a enzima BamHI (Figura 42A), indicado a direção correta desse fragmento, e entre 16362072pb (1819pb) (Figura 42B) quando clivados com a enzima HindIII, indicando a presença do inserto gDVac2.

A partir dos resultados obtidos com as PCRs e a análise de restrição, os dois plasmídeos recombinantes, pVAXgDVac2_2 e 3, foram analisados por seqüenciamento utilizando-se os oligonucleotídeos T7 e FgDApaseq (Figuras 43) para confirmação da sequiência e posterior utilização nos ensaios in vitro e in vivo. 

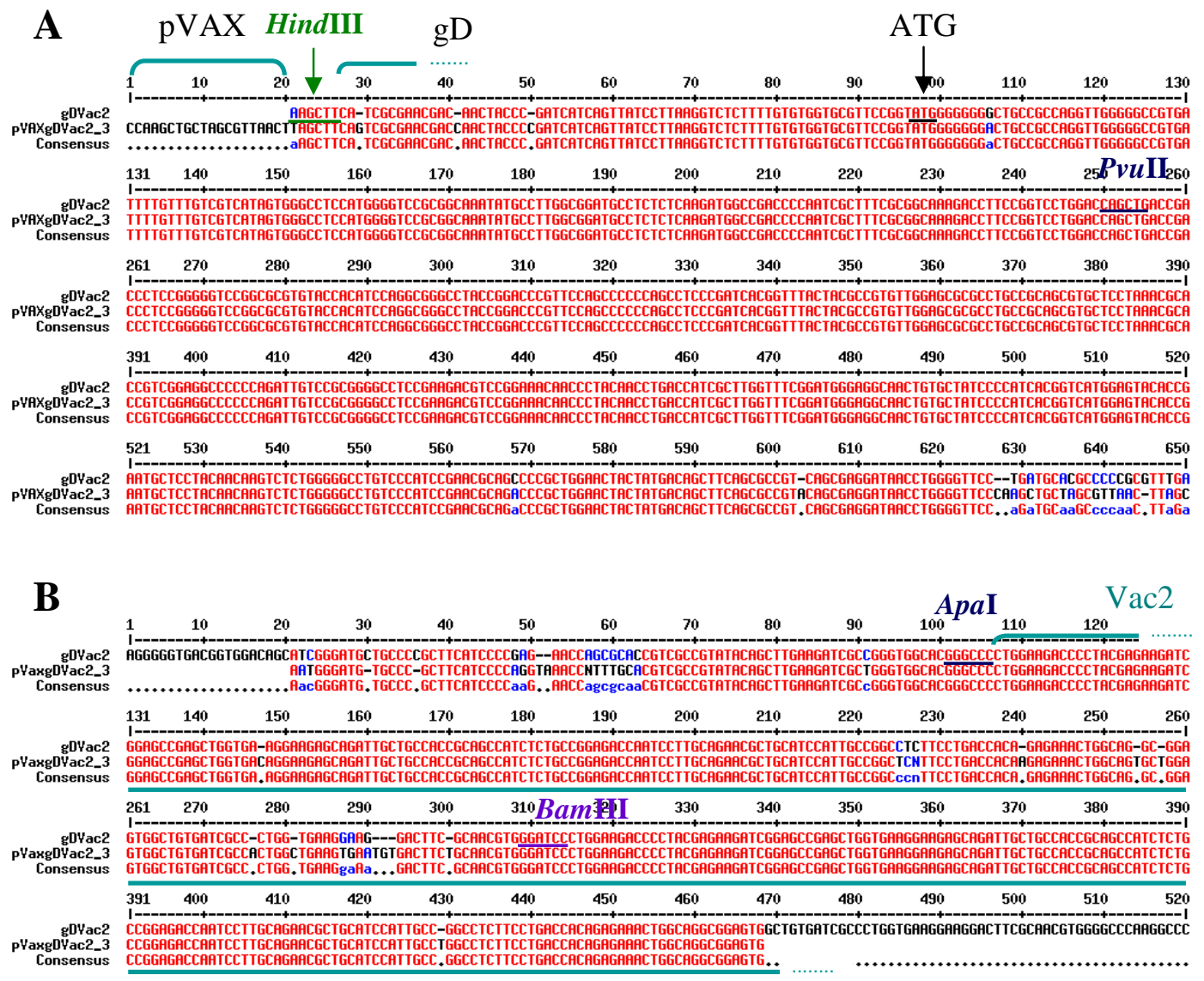

Figura 43: Alinhamento do fragmento gDVac2 com o clone pVAXgDVac2_3. A) gDVac2 alinhada com o clone pVAXgDVac2_3 seqüenciado com o primer T7, em destaque o sítio da enzima HindIII utilizada na retirada do fragmento, o inicio do gene da $\mathrm{gD}$, o primeiro códon a ser traduzido em proteína (ATG), o sítio da enzima PvuII. B) gDVac2 alinhada com o clone pVAXgDVac2_3 seqüenciado com o primer FgDApaseq, em destaque os sítios da enzima $A p a \mathrm{I}$, a seqüência da Vac2 e o sítio da enzima BamHI no interior do fragmento Vac2.

A partir do seqüenciamento foi possível visualizar o inicio (Figura 43A) do fragmento gDVac2, confirmando a presença do fragmento na direção correta no interior do vetor pVAX, e a presença do fragmento Vac2 (Figura 43B) no interior da gD. 


\subsection{Purificacão das construcões vacinais}

\subsubsection{Avaliação da integridade dos plasmídeos purificados}

Os plasmídeos das quatro construções vacinais, pVAXgD, pVAXgDVac1AA, pVAXgDVac1PA e pVAXgDVac2 foram extraídos e avaliados quanto a integridade pela digestão com a enzima HindIII (Figura 44).

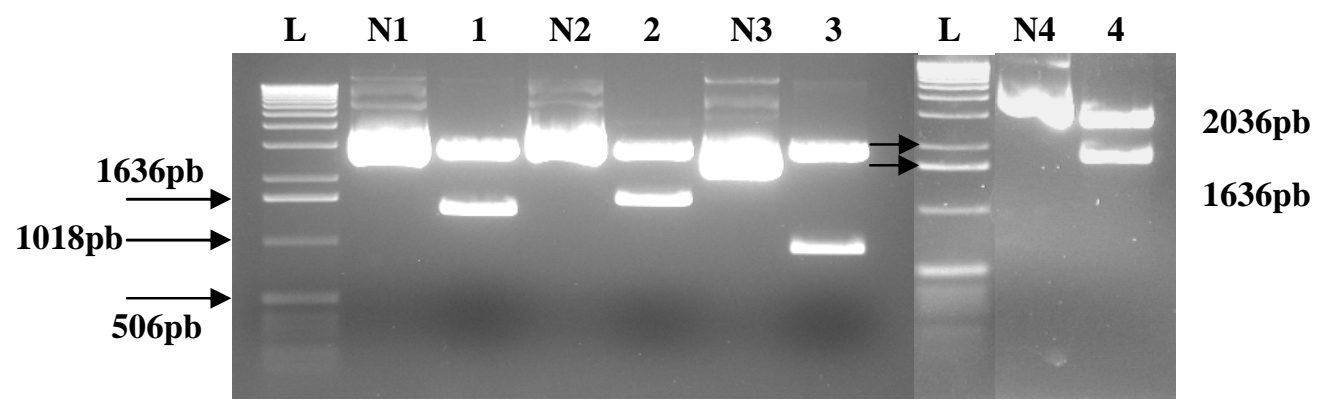

Figura 44: Clivagem das construções vacinais. pVAXgD, pVAXgDVac1AA, pVAXgDVac1PA e pVAXgDVac2 clivados com a enzima HindIII. L-marcador de 1Kb, N1 a N4-pVAXgD, pVAXgDVac1AA, pVAXgDVac1PA e pVAXgDVac2 não digeridos e 1 a 4-pVAXgD, pVAXgDVac1AA, pVAXgDVac1PA e pVAXgDVac2 digeridos com HindIII.

A caracterização dos plasmídeos pVAXgD, pVAXgDVac1AA, pVAXgDVac1PA e pVAXgDVac2 demonstra a presença dos fragmentos gD (1423pb), gDVac1AA (1621pb), gDVac1PA (973pb) e gDVac2 (1823pb) nesses vetores. Além disso, eles foram avaliados quanto a presença de endotoxinas demonstrando níveis inferiores aos requeridos para materiais utilizados como injetáveis $(<0,01$ unidades de endotoxinas/ $\mu \mathrm{g}$ de DNA).

\subsection{Expressão e Purificacão das proteínas Vac1 e Vac2}

A expressão, o teste de solubilidade e a purificação das proteínas recombinanes Vac1 (Figuras 45) e Vac2 (Figuras 46) foram analisados em SDS-PAGE a 13,5\% 

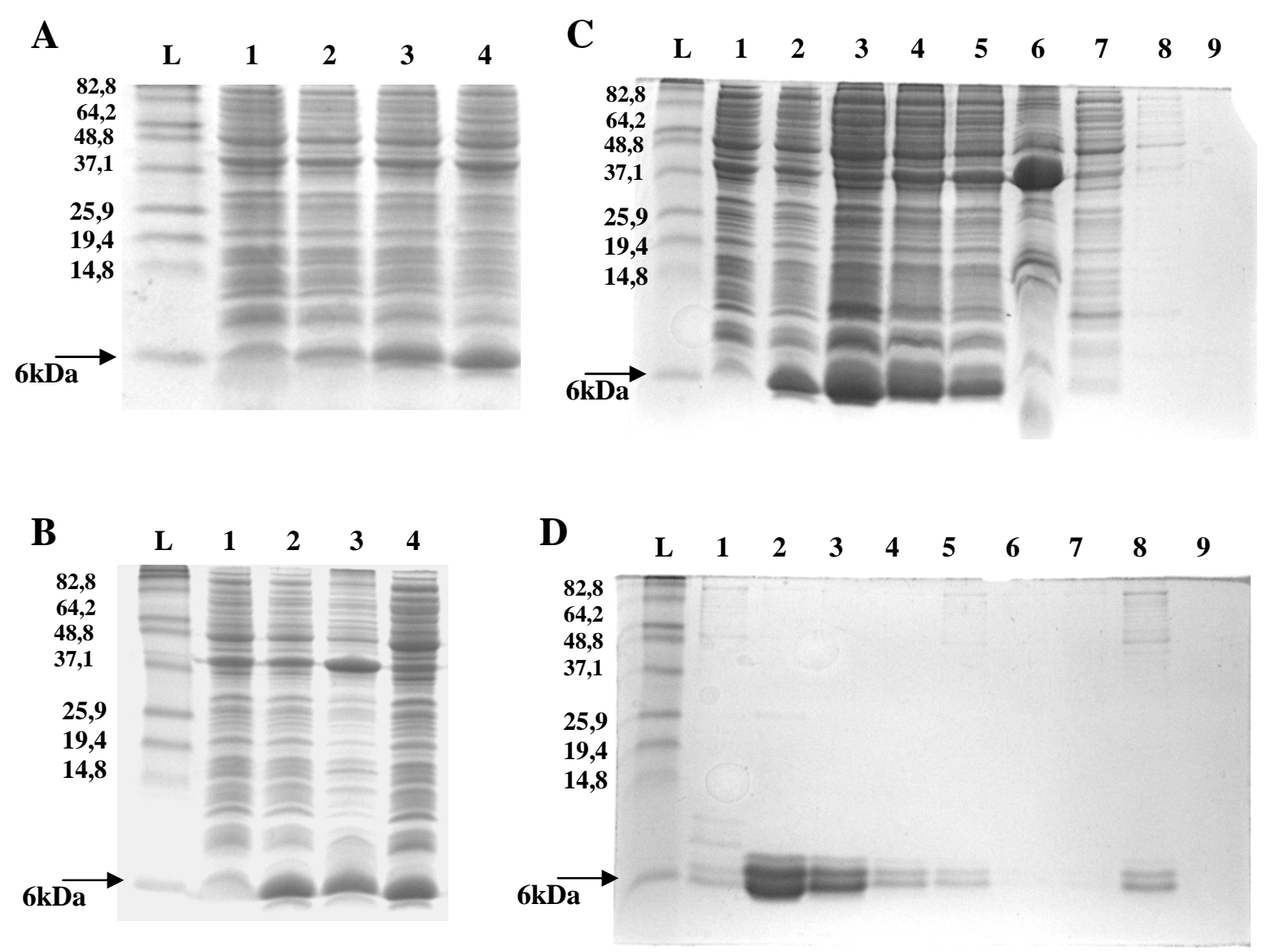

Figura 45: Expressão, Teste de solubilidade e Purificação da proteína recombinante Vac1. A) Expressão da proteína Vac1, L-marcador - proteínas com massas moleculares conhecidas foram usadas como marcadores da migração (Bench Mark Pré-Stained Protein Ladder - Invitrogen), 1-não induzido (sem adição de IPTG), 2-3 horas após adição de IPTG, 3-4 horas após adição de IPTG, 4- 16 horas após adição de IPTG. B) Teste de solubilidade da proteína Vac1 utilizando tampão sem uréia, 1-não induzido, 2-4 horas após adição de IPTG, 3sedimento após lise celular, 4-sobrenadante após lise celular. C) Expressão, Teste de solubilidade com uréia e Purificação da proteína Vac1, 1-não induzido, 2-4 horas após adição de IPTG, 3-sobrenadante 1 (após lise celular), 4-sobrenadante 2, 5-sobrenadante 3, 6-sedimento após três sonicações, 7-eluato, 8-lavagem e 9-eluição com 150mM de imidazol, fração 1. D) Purificação da proteína Vac1, eluição com gradiente de imidazol: 1150mM fração 2, 2-150mM fração 3, 3-150mM fração 4, 4-250mM fração 1, 5-250mM fração 2, 6-250mM fração 3, 7-500mM fração 1, 8-500mM fração 2, 9-500mM fração 3.

A proteína Vac1 foi expressa após 3, 4 e 16 horas da adição de IPTG, como é visto na figura 45A, pela presença de uma banda de massa aproximada de $6 \mathrm{kDa}$ condizente com a massa da proteína Vac1 de 7,52kDa. Um aumento da expressão foi detectado apenas entre 3 e 4 horas de indução, no entanto, não houve grande diferença entre esse período e 16 horas (Figura 45A). Após a expressão, foi realizado o teste de solubilidade, inicialmente com tampão de lise sem agente desnaturante (sem uréia) para verificar se a proteína era expressa 
na forma solúvel. Como demonstrado pela figura 45B a proteína Vac1 estava presente na forma solúvel, mas também apresentava uma fração no sedimento celular.

Após essas avaliações, a proteína Vac1 foi expressa por 4 horas com adição de IPTG (Figura 45C) e solubilizada pela adição de uréia no tampão de lise (também chamado tampão de sonicação) para obtenção de maior quantidade da proteína na fração solúvel. Após a lise celular realizada com a enzima lisozima, sonicação e tampão desnaturante a proteína foi vista apenas na fração solúvel (sobrenadantes 1, 2 e 3) (Figura 45C).

A proteína Vac1 foi, em seguida, purificada por cromatografia de afinidade sendo eluída em maior quantidade e livre de contaminantes nas frações de imidazol 150mM 3 e 4 (Figura 45D) que foram utilizadas na diálise para retirada do imidazol e uréia e utilização nos ensaios in vitro. 
A
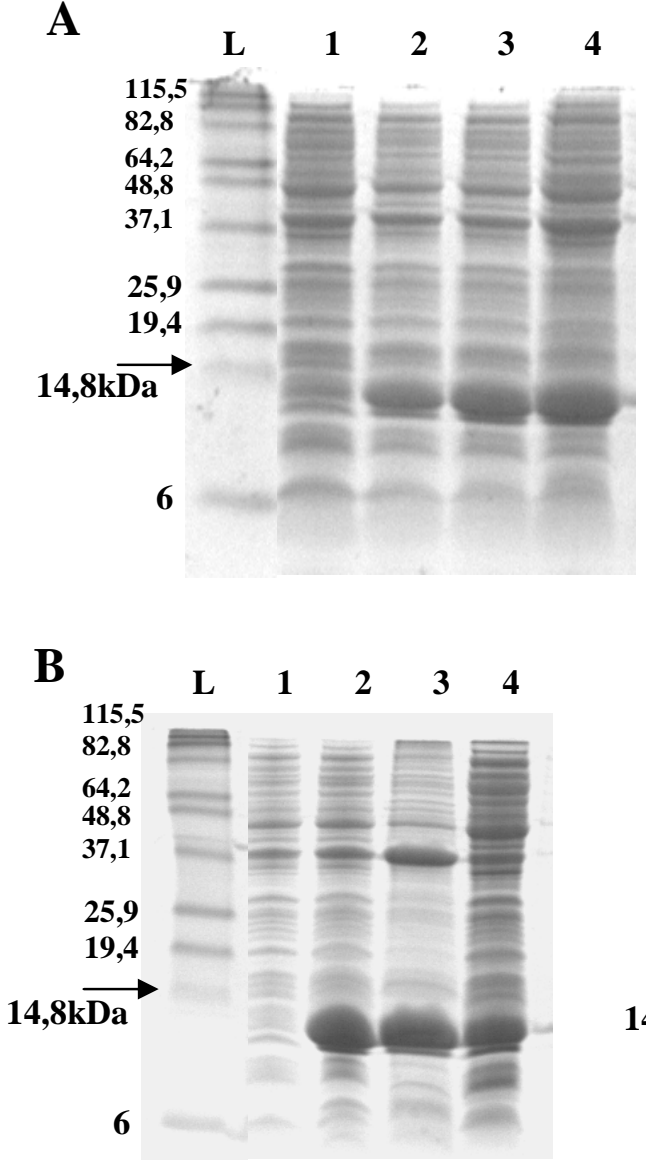

\section{C}
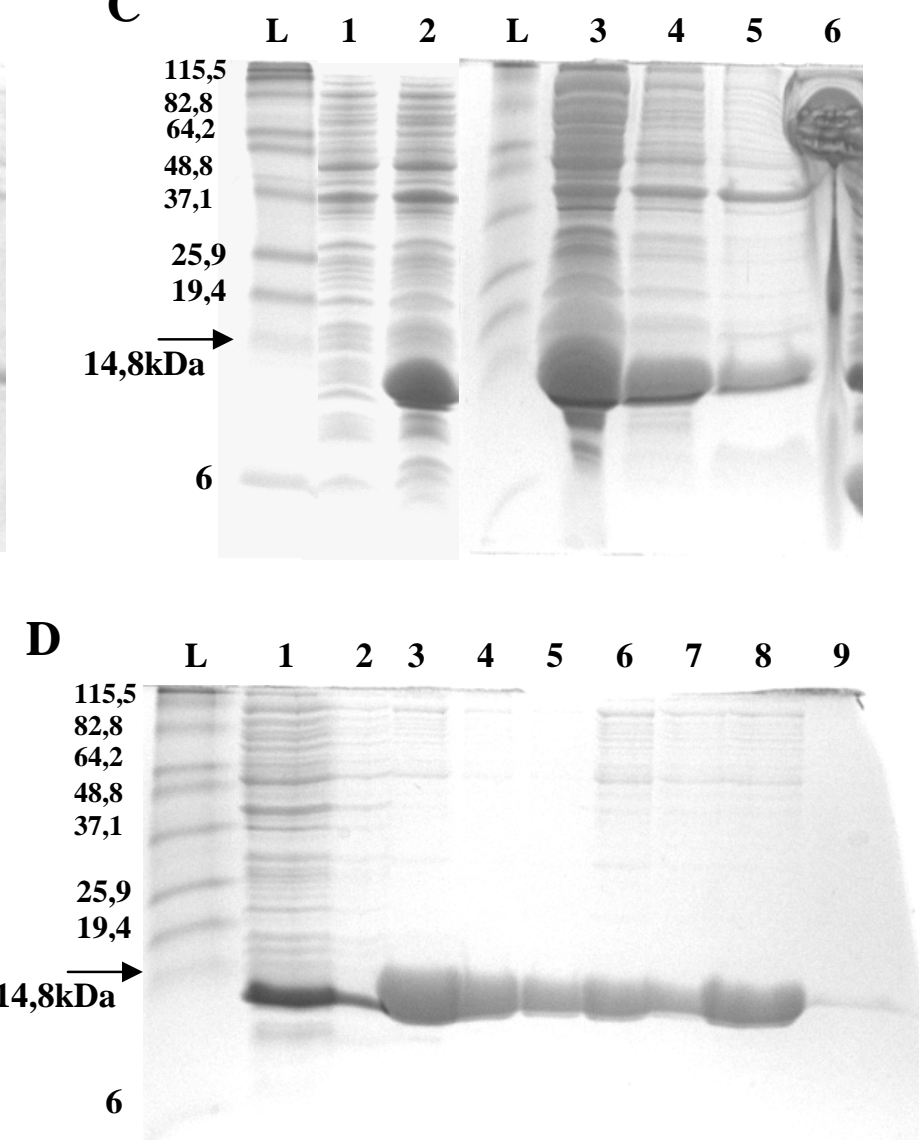

Figura 46: Expressão, Teste de solubilidade e Purificação da proteína recombinante Vac2. A) Expressão da proteína Vac2, L-marcador (Invitrogen), 1-não induzido, 2-3 horas após adição de IPTG, 3-4 horas após adição de IPTG, 4-16 horas após adição de IPTG. B) Teste de solubilidade da proteína Vac2 utilizando tampão sem uréia, 1-não induzido, 2-4 horas após adição de IPTG, 3-sedimento após lise celular, 4-sobrenadante após lise celular. C) Expressão, Teste de solubilidade com uréia e Purificação da proteína Vac2, 1-não induzido, 2-4 horas após adição de IPTG, 3-sobrenadante 1 (após lise celular), 4-sobrenadante 2, 5-sobrenadante 3, 6-sedimento após três sonicações, 7-eluato, 8-lavagem e 9-eluição com $150 \mathrm{mM}$ de imidazol, fração 1. D) Purificação da proteína Vac2, 1-eluato, 2-lavagem, eluição com gradiente de imidazol: 3-150mM fração 2, 4-150mM fração 3, 5$150 \mathrm{mM}$ fração 4, 6-250mM fração 2, 7-250mM fração 3, 8-500mM fração 2 e 9-500mM fração 3.

A proteína Vac2, assim como a Vac1, foi expressa após 3, 4 e 16 horas da adição de IPTG, como é visto na figura 46A, pela presença de uma banda de massa aproximada de $15 \mathrm{kDa}$ condizente com a massa da proteíva Vac2 de 14,44kDa. Um aumento da expressão foi detectado apenas entre 3 e 4 horas de indução, no entanto, não houve grande diferença entre esse período e 16 horas (Figura 46A). Após a expressão foi realizado o teste de solubilidade inicialmente com tampão de lise sem agente desnaturante. Como demonstrado pela figura 46B 
a proteína Vac2 estava presente na forma solúvel, mas também apresentava uma fração no sedimento celular.

Após essas avaliações a proteína Vac2 foi expressa por 4 horas com adição de IPTG (Figura 46C) e solubilizada pela adição de uréia no tampão de lise para obtenção de maior quantidade da proteína na fração solúvel. Após a lise celular realizada com a enzima lisozima, sonicação e tampão com uréia, a proteína foi vista apenas na fração solúvel (sobrenadantes 1, 2 e 3) (Figura 46C).

A proteína Vac2 foi, em seguida, purificada por cromatografia de afinidade, sendo eluída em maior quantidade e livre de contaminantes nas frações de 150mM 3 e 4 (Figura 46D) que foram utilizadas na diálise da proteína.

As proteínas recombinantes após diálise foram quantificadas, avaliadas quanto a presença de endotoxinas, demonstrando níveis aceitáveis para o uso em animais e cultura de células sendo, portanto, utilizadas nos experimentos de produção de anticorpos policlonais e imunogenicidade.

\subsection{Produção e Caracterização dos anticorpos policlonais anti-Vac1 e anti-Vac2}

As proteínas recombinantes Vac1 e Vac2 foram utilizadas na imunização de camundongos BALB/c para a produção de anticorpos policlonais anti-Vac1 e anti-Vac2. Os soros contendo anticorpos anti-Vac1 e anti-Vac2 foram caracterizados para detectar se esses anticorpos reagiam cruzadamente com a proteína Hsp60 de mamíferos, uma vez que células humanas HEK293 foram utilizadas nos ensaios de transfecções para caracterização das vacinas construídas, e devido a utilização dessas proteínas na forma de DNA (vacina construídas) na imunização de camundongos. A figura 63 demonstra se os anticorpos antiHsp60 (Figura 47A), anti-Vac1 (Figura 47B) e anti-Vac2 (Figura 47C) reagem com a proteína Hsp60 das células HEK293. 
A

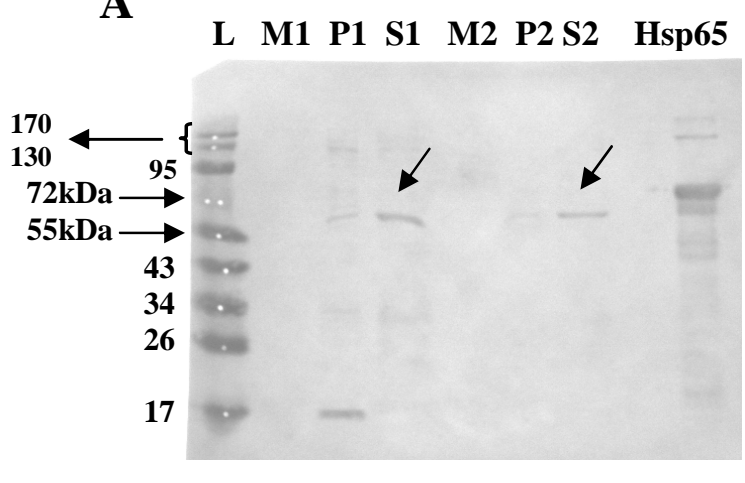

B

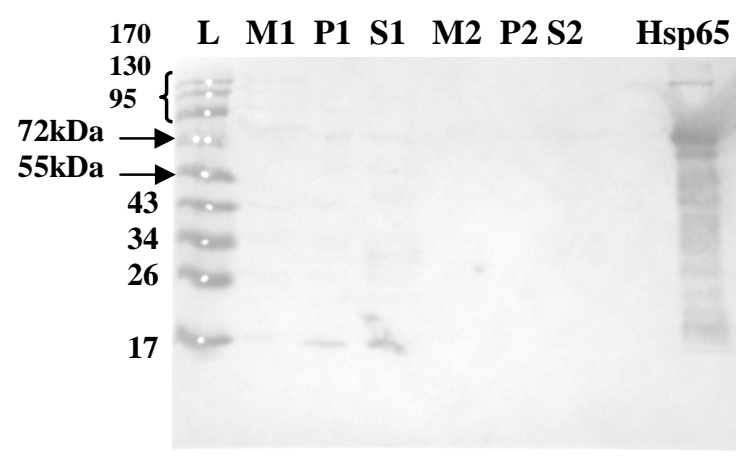

$\mathbf{C}$

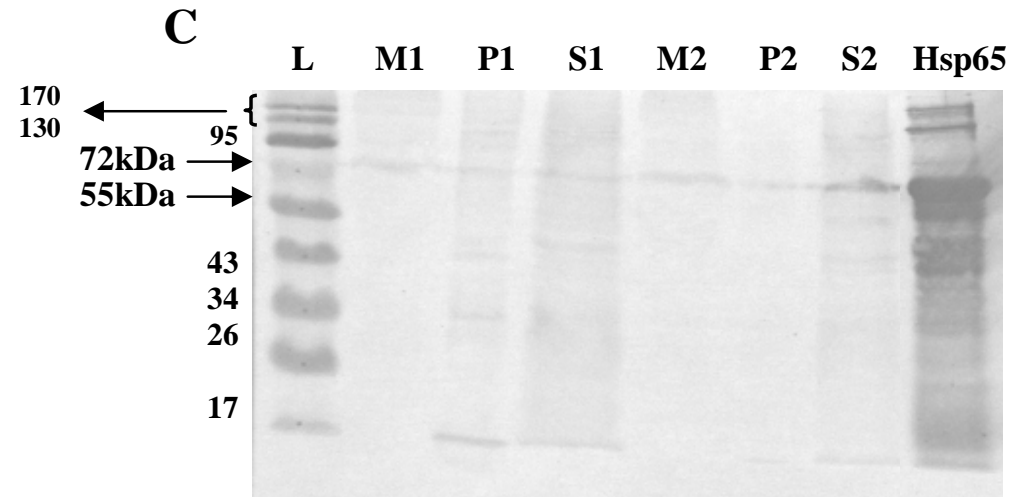

Figura 47: Caracterização dos anticorpos anti-Vac1 e anti-Vac2. A) "Western blot" utilizando o anticorpo anti-Hsp60; B) "Western blot" utilizando o anticorpo anti-Vac1; C) "Western blot" utilizando o anticorpo antiVac2. L-marcador - proteínas com massas moleculares conhecidas foram usadas como marcadores da migração (PageRuler Prestained Protein Ladder - Fermentas), 1-células HEK293 incubadas a 370 , 2-células HEK293 incubadas por 5 horas a $42^{\circ} \mathrm{C}$; M-meio de cultura, P-sedimento e S-sobrenadante.

A figura 63 mostra que as células HEK293 submetidas a um estresse térmico $\left(42^{\circ} \mathrm{C}\right)$, para detecção da expressão da proteína Hsp60, e também mantidas a $37^{\circ} \mathrm{C}$, como controle, apresenta reatividade apenas com o anticorpo anti-Hsp60 (Figura 47A). Os anticorpos antiVac1 (Figura 47B) e anti-Vac2 (Figura 47C) não foram capazes de reconhecer essa proteína demonstrando a especificidade desses anticorpos e indicando que na transfecção das células HEK com as construções vacinais esses anticorpos revelam as proteínas de interesse (proteínas codificadas pelas vacinas). 


\subsection{Avaliação in vitro da funcionalidade das vacinas construídas}

\subsubsection{Transfecção de células in vitro}

Para detecção da transcrição e tradução das proteínas codificadas pelas vacinas de DNA pVAXgD, pVAXgDVac1AA, pVAXgDVac1PA e pVAXgDVac2, células eucarióticas HEK293 foram transfectadas sendo a eficiência na transfecção dessas células avaliada pela utilização do plasmídeo pGreen (Figura 48), que expressa a proteína GFP (visível em microscópio de fluorescência com a cor verde). Esse é um controle importante visto que as proteínas podem não ser detectadas por ineficiência do método de transfecção.
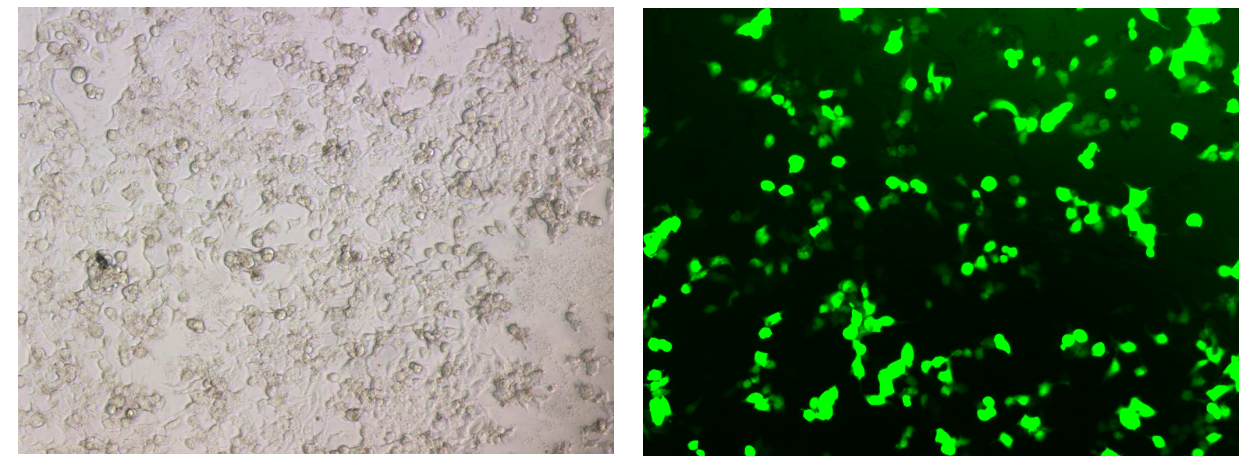

Figura 48: Transfecção de células HEK. Células HEK293 transfectadas com o plasmídeo pGreen após 24 horas. A esquerda células em campo claro e a direita vista por microscopia de fluorescência.

Como é visto na figura 64, a transfecção foi eficiente o que pode ser aferido também para as transfecções com as construções vacinais visto que o procedimento é o mesmo para ambas as transfecções.

\subsubsection{Análise da transcrição do RNA mensageiro}

As células HEK293 após 24 horas de transfecção com as construções vacinais pVAXgD, pVAXgDVac1AA, pVAXgDVac1PA e pVAXgDVac2 foram utilizadas na extração de RNA (Figuras 49) para posterior avaliação da presença do RNA mensageiro dos “genes" gDVac1AA, gDVac1PA e gDVac2 (Figuras 50). 


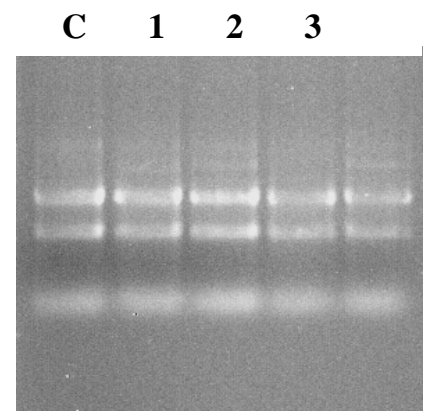

Figura 49: Extração de RNA. RNA extraído após 24 horas da transfecção das células HEK293 com as construções vacinais. C-RNA das células HEK não transfectadas, 1-RNA das células HEK transfectadas com pVAXgD, 2-RNA das células HEK transfectadas com pVAXgDVac1AA, 3-RNA das células HEK transfectadas com pVAXgDVac1PA e 4-RNA das células HEK transfectadas com pVAXgDVac2.

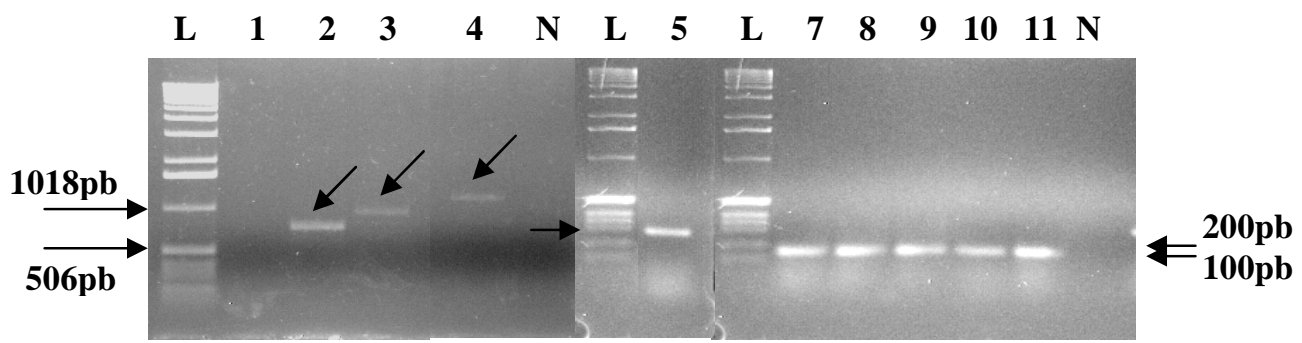

Figura 50: Caracterização dos transcritos. Avaliação da presença do RNA mensageiro dos "genes" gDVac1AA, gDVac1PA e gDVac2 L-marcador de 1Kb, 1 ao 5-amplificação utilizando os primers FgDPvu e RgDApa e os cDNAs feitos a partir dos RNAs extraídos das células HEK não transfectada (1) ou transfectadas com os plasmídeos pVAXgD (2), pVAXgDVac1AA (3), pVAXgDVac2 (4) e pVAXgDVac1PA (5) respectivamente. 7 ao 11-amplificação utilizando-se os mesmos cDNAs e os primers GAPDH sense e antisense. $\mathrm{N}$-controle negativo.

Como é visto na figura 49, todos os RNAs extraídos estavam íntegros e foram utilizados na produção do cDNA que por sua vez foi utilizado na verificação da presença de RNA mensageiro para os "genes" gDVac1AA, gDVac1PA e gDVac2 (Figura 50). A amplificação utilizando os primers FgDPvu e RgDApa para verificação da presença dos transcritos nas células HEK293 transfectadas com as construções vacinais revelou bandas entre 506-1018pb, para as células transfectadas com pVAXgD condizente com o tamanho esperado de 758pb; bandas próximas a 1018pb para as transfecções com pVAXgDVac1AA e pVAXgDVac2, cujos tamanhos esperados eram 956 e 1154pb e banda próxima a 298pb para o pVAXgDVac1PA (308pb). Além disso, nenhuma banda foi vista nas células sem 
transfecção e no controle negativo. Para todas as células com ou sem transfecção obteve-se a amplificação do gene GAPDH (178pb), como controle positivo do experimento.

\subsubsection{Análise da expressão das proteínas recombinantes}

Células HEK293 foram transfectadas com as construções pVAXgD, pVAXgDVac1AA, pVAXgDVac1PA e pVAXgDVac2 e após 24 horas avaliou-se a expressão das proteínas por "Western blot" utilizando-se os anticorpos policlonais anti-Vac1 (Figuras 51), anti-Vac2 (Figura 52) e anti-gD (Figura 53).

$\mathbf{A}$

$\begin{array}{lllllllllll}\text { L } & \text { MC } & \text { PC } & \text { SC } & \text { M1 } & \text { P1 } & \text { S1 } & \text { M2 } & \text { P2 } & \text { S2 }\end{array}$

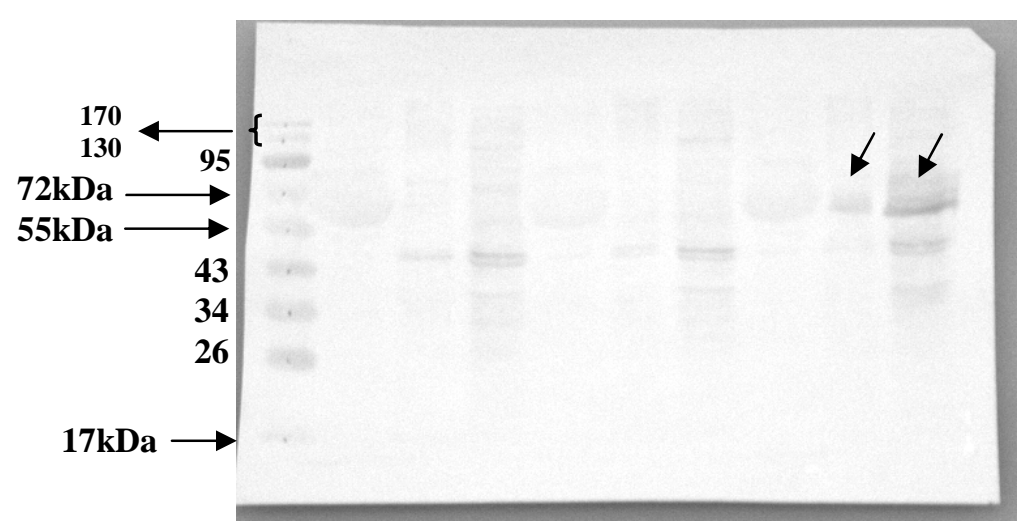

B

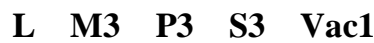

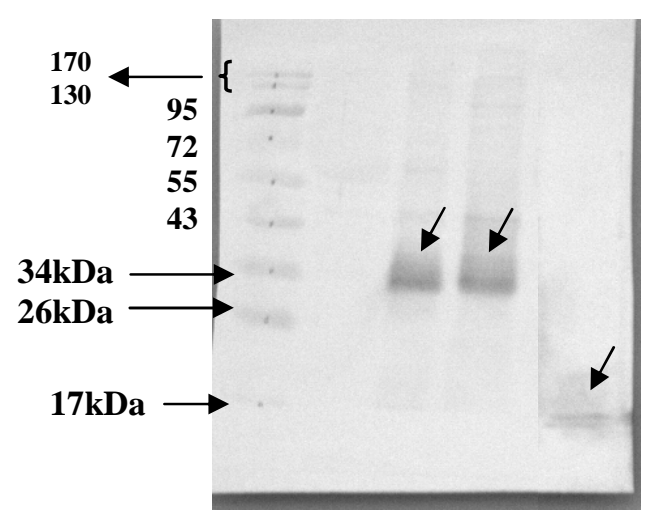

Figura 51: Expressão das proteínas recombinantes. Avaliação da expressão das proteínas recombinantes em células HEK293 transfectadas com os plasmídeos A) pVAXgD e pVAXgDVac1AA e B) pVAXgDVac1PA, após 24 horas de transfecção utilizando-se a técnica de "Western blot" com anticorpo anti-Vac1. L-marcador (Fermentas), M-meio de cultura, P-sedimento (fração celular insolúvel) e S-sobrenadante (fração celular solúvel), C-células não transfectadas, 1-transfecção com pVAXgD, 2-transfecção com pVAXgDVac1AA e 3transfecção com pVAXgDVac1PA. Vac1-proteína recombinante purificada. 


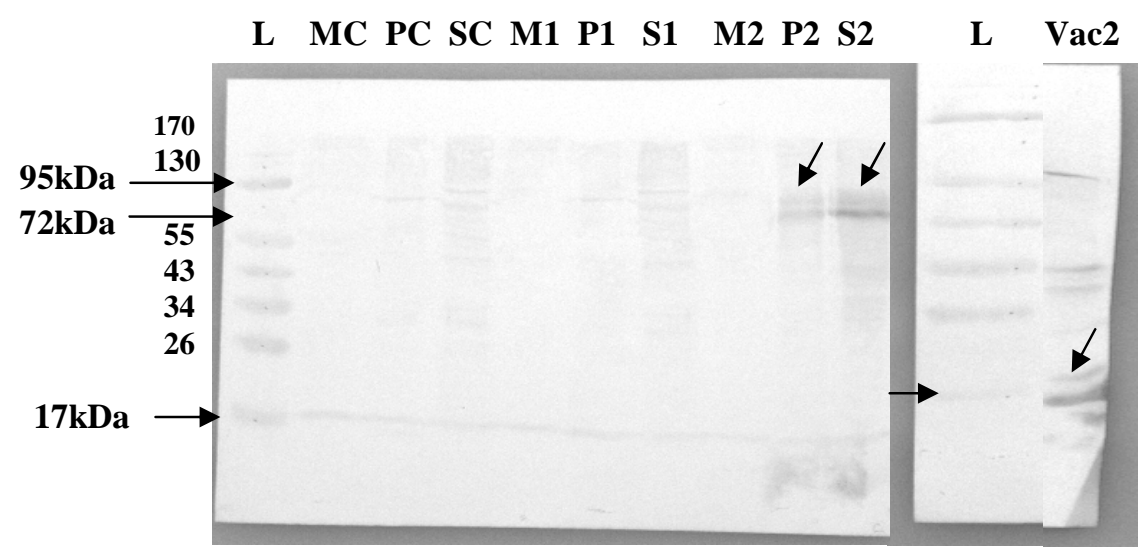

Figura 52: Expressão das proteínas recombinantes. Avaliação da expressão das proteínas recombinantes em células HEK293 transfectadas com os plasmídeos pVAXgD e pVAXgDVac2 após 24 horas de transfecção utilizando-se a técnica de "Western blot" com anticorpo anti-Vac2. L-marcador (Fermentas), M-meio de cultura, P-sedimento (fração celular insolúvel) e S-sobrenadante (fração celular solúvel), C-células não transfectadas, 1transfecção com pVAXgD, 2-transfecção com pVAXgDVac2 e Vac2-proteína recombinante purificada.

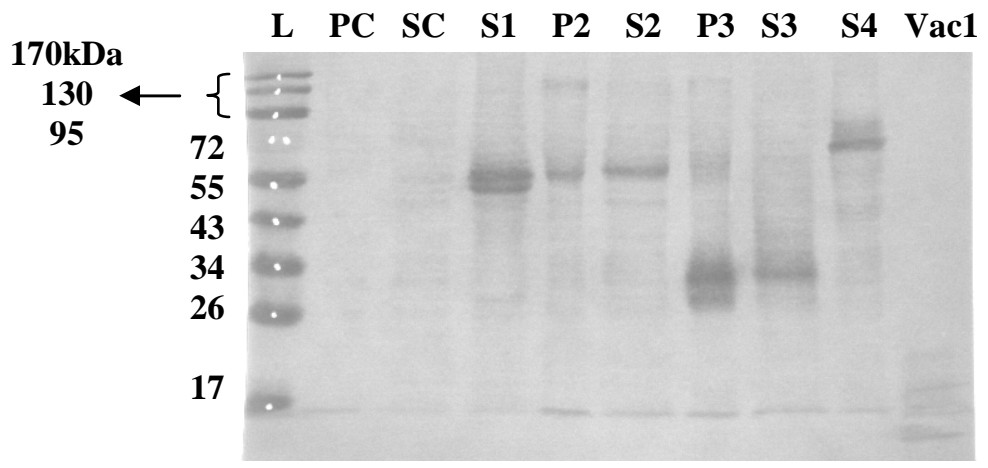

Figura 53: Expressão das proteínas recombinantes. Avaliação da expressão das proteínas recombinantes em células HEK293 transfectadas com os plasmídeos pVAXgD, pVAXgDVac1AA, pVAXgDVac1PA e pVAXgDVac2 após 24 horas de transfecção utilizando-se a técnica de "Western blot" com anticorpo anti-gD. Lmarcador (Fermentas), P-sedimento e S-sobrenadante, C-células não transfectadas, 1-transfecção com pVAXgD, 2-transfecção com pVAXgDVac1AA, 3-transfecção com pVAXgDVac1PA, 4-transfecção com pVAXgDVac2 e Vac1-proteína recombinante purificada.

As células HEK293 transfectadas com o plasmídeo pVAXgDVac1AA expressaram a proteína gDVac1AA (461aas - 50,01kDa - massa determinada pelo programa GeneRuner), como visto nos "Western blots" com os anticorpos anti-Vac1 (Figura 51A) e anti-gD (Figura 53), que revelaram uma banda entre 55-72kDa. As células HEK293 transfectadas com o plasmídeo pVAXgDVac1PA expressaram a proteína gDVac1PA (245aas - 25,88kDa), identificada nos "Western blots" com os anticorpos anti-Vac1 (Figura 51B) e anti-gD (Figura 53) que revelaram uma banda entre $34-26 \mathrm{kDa}$, tamanho menor devido a retirada de uma 
porção da gD. Já as células transfectadas com pVAXgDVac2 expressaram a proteína gDVac2 (527aas - 56,71kDa), identificada nos "Western blots" com os anticorpos anti-Vac2 (Figura 52) e anti-gD (Figura 53) que revelaram uma banda próxima a 72kDa. As células não transfectadas apresentaram apenas revelações inespecíficas com os três anticorpos (Figuras 51A e 52) e as transfectadas com pVAXgD apresentaram revelações inespecíficas com os anticorpos anti-Vac1 (Figura 51A) e anti-Vac2 (Figura 52) e uma banda entre 43-55kDa com o anticorpo anti-gD demonstrando a presença da proteína gD de 43,35kDa (395aas) (Figura 53). As proteínas não estavam presentes no meio de cultura (M), indicando que não foram secretadas, no entanto, estavam presentes no sedimento $(\mathrm{P})$ e sobrenadante $(\mathrm{S})$ celulares, isto é, tanto na fração insolúvel quanto na fração solúvel, respectivamente. O controle positivo foi feito com as proteínas Vac1 e Vac2 recombinantes e purificadas cujo tamanho são 7,52kDa (71aas) e 14,44kDa (138aas), respectivamente, diferentemente das proteínas reveladas nas transfecções, pois nesse caso a Vac1 e Vac2 estão fusionadas a gD (43,35kDa).

Esses resultados juntamente com a análise dos transcritos e o seqüenciamento dos clones indicam que as quatro vacinas foram construídas corretamente estando em fusão com a proteína $\mathrm{gD}$.

\subsection{Avaliacão da resposta imunológica}

Após a construção e caracterização das vacinas pVAXgD, pVAXgDVac1AA, pVAXgDVac1PA e pVAXgDVac2, estas foram utilizadas, juntamente com o vetor pVAX e a vacina pVAXhsp65 (Anexos 2 e 3) na imunização de camundongos para avaliação da imunogenicidade dessas construções.

\subsubsection{Avaliação da resposta imunológica humoral}

A resposta humoral foi avaliada no soro dos animais imunizados após 30 dias da última imunização. 


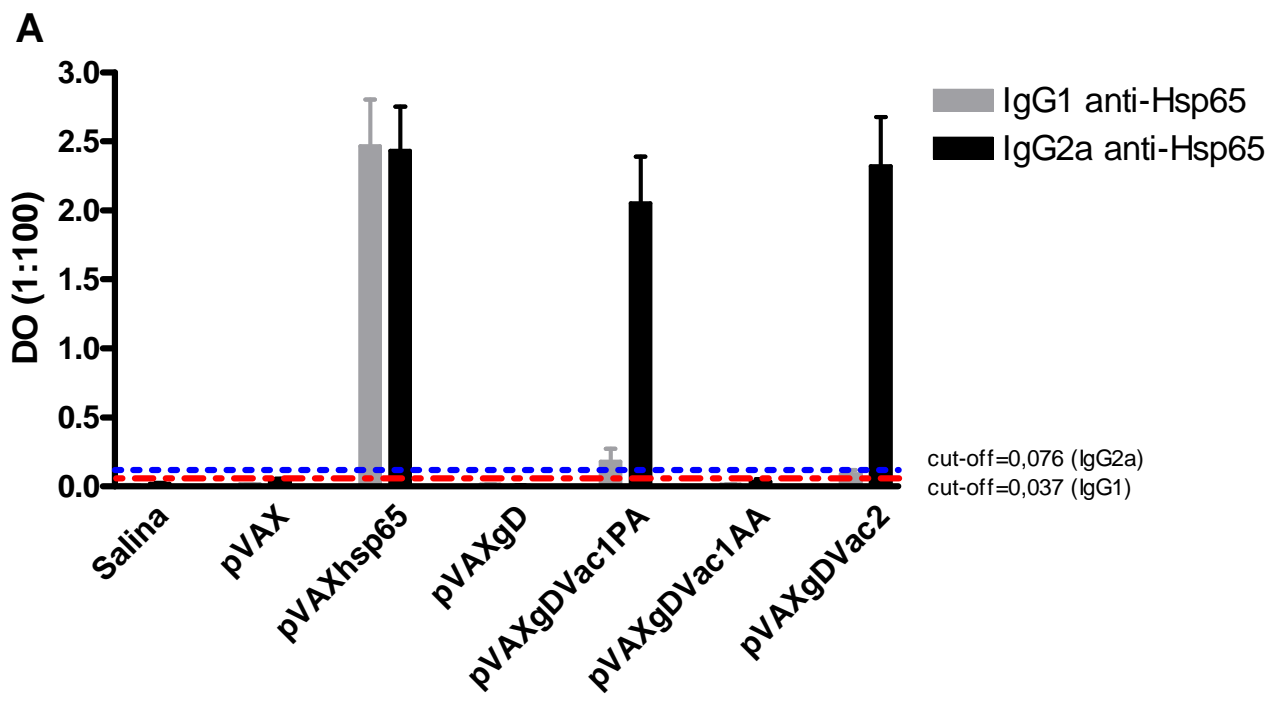

B

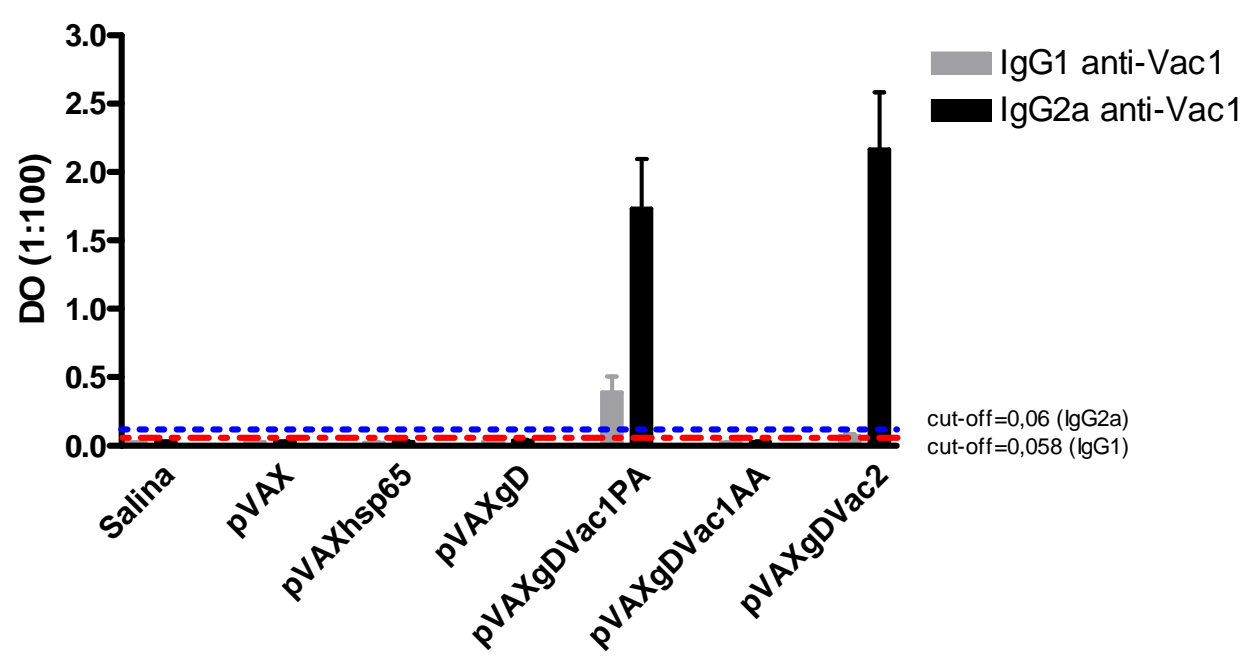

C

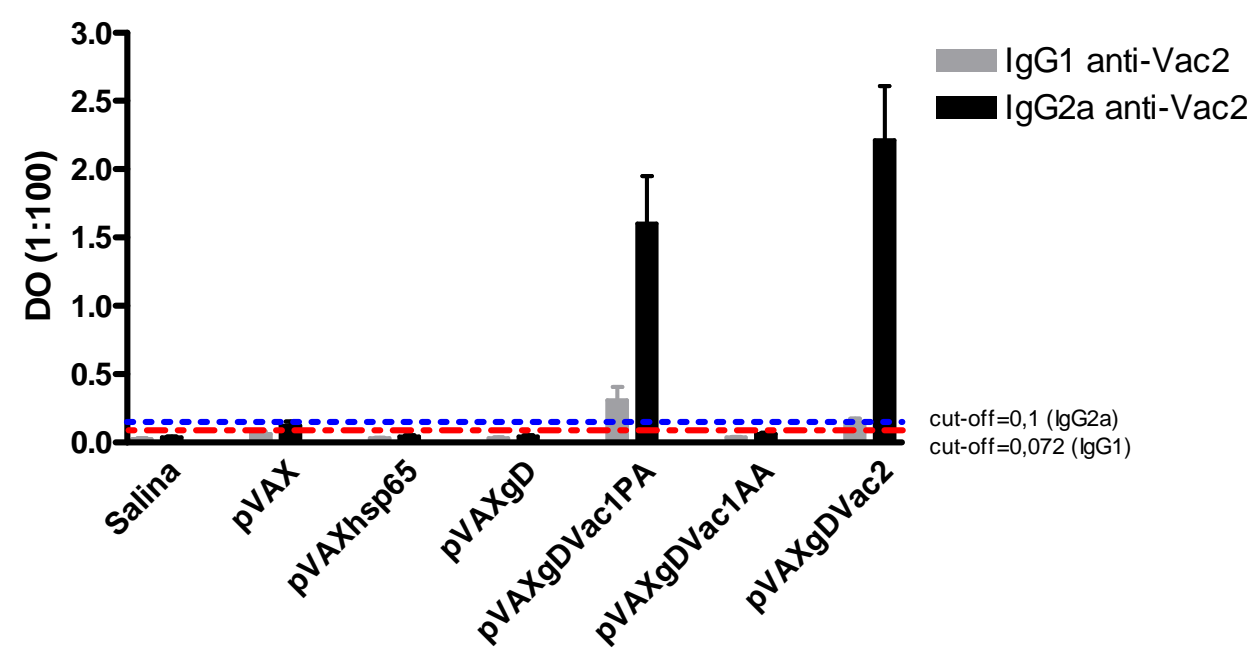

Figura 54: Resposta imunológica humoral. A) Produção de anticorpos anti-Hsp65, B) Produção de anticorpos anti-Vac1 e C) Produção de anticorpos anti-Vac2. Resultado representativo de dois experimentos com n de 5 a 9. Cut-off foi calculado pela multiplicação do desvio do grupo controle (salina) por três e somado a média de produção de anticorpos desse mesmo grupo, sendo utilizado para indicar os grupos que produziram anticorpos. 
Como foi visto na figura 54A, B e C as vacinas pVAXgDVac1PA e pVAXgDVac2 foram capazes de induzir a produção de anticorpos do subtipo IgG2a anti-Hsp65, anti-Vac1 e anti-Vac2 indicando a presença de um padrão Th1 de resposta. Já a vacina pVAXhsp65 induziu a produção de anticorpos dos subtipos IgG1 e IgG2a apenas anti-Hsp65, demonstrando um padrão misto de resposta (Th1 e Th2). Os grupos controles representados pelos animais imunizados com salina e vetores ( $\mathrm{pVAX}$ e pVAXgD) não foram capazes de induzir resposta humoral contra as proteínas Hsp65, Vac1 e Vac2. Os animais imunizados com a vacina pVAXgDVac1AA não foram capazes de induzir a produção de anticorpos para nenhuma das proteínas utilizadas.

\subsubsection{Avaliação da resposta imunológica celular}

\subsubsection{Proliferação de linfócitos $T$}

A resposta celular foi avaliada, após 30 dias da última imunização, pela proliferação das células do baço, dos animais imunizados, estimuladas ex vivo. Essas células foram estimuladas por 72 horas com ConA (Figura 55A) ou com as proteínas recombinantes Hsp65 (Figura 55B), Vac1 (Figura 55C) e Vac2 (Figura 55D) e a proliferação avaliada pela incorporação de timidina tritiada medida em um contador de cintilação $\beta$. Como controle negativo foi utilizado células tratadas apenas com meio de cultura, sem estímulo. 
A

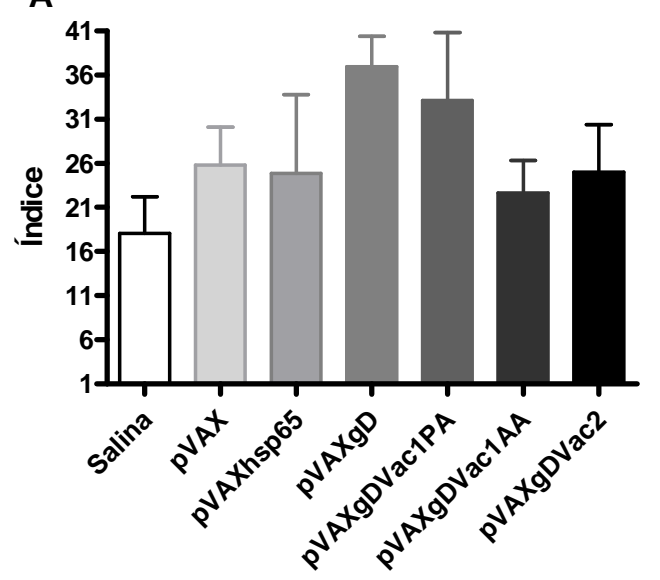

C

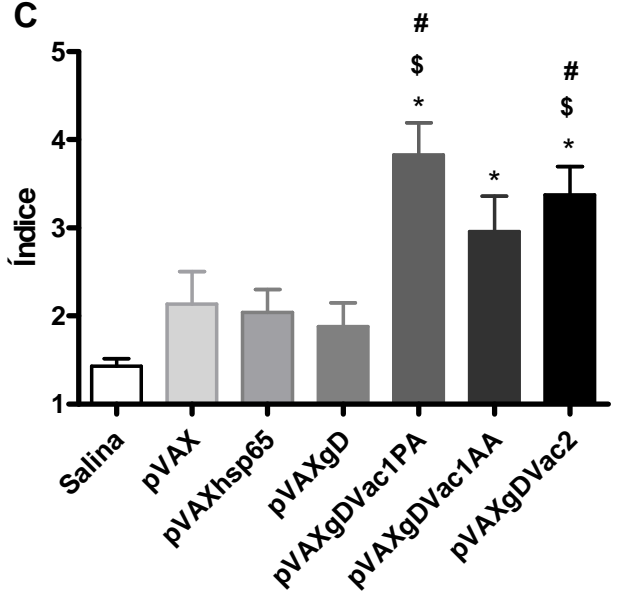

B
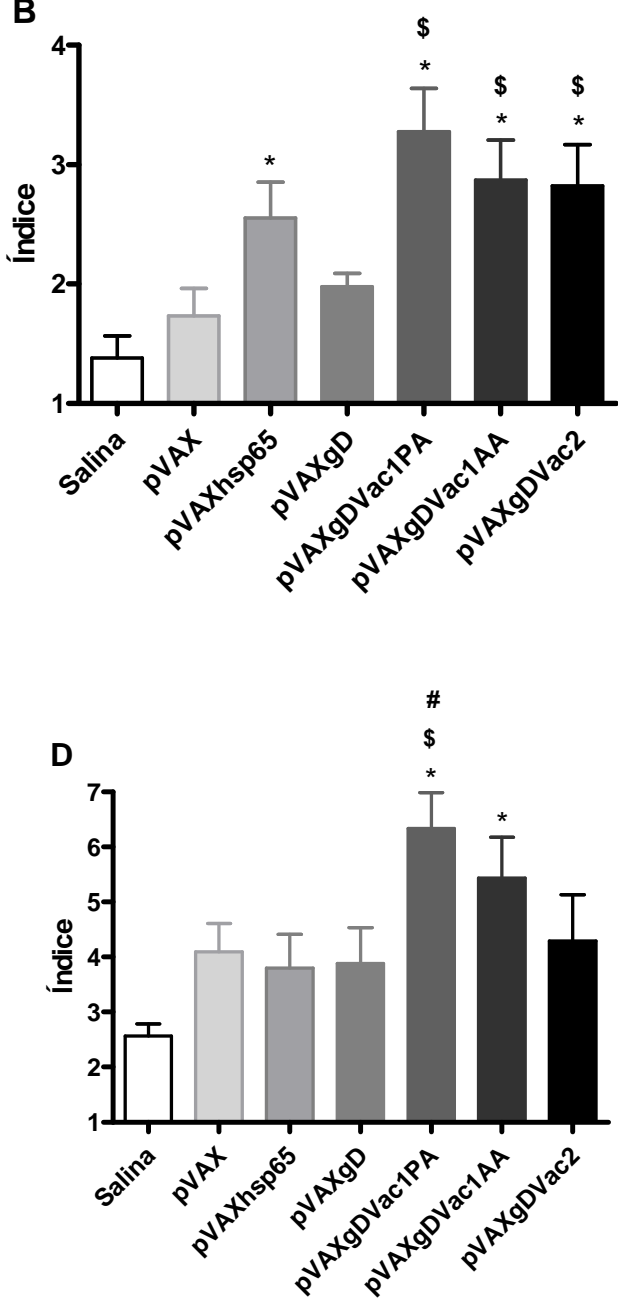

Figura 55: Proliferação de linfócitos T. A) Células do baço estimuladas com ConA (controle positivo), B) proteína Hsp65, C) proteína Vac1 e D) proteína Vac2. Células do baço foram estimuladas ex vivo por 72 horas e a proliferação ensaiada pela incorporação de $\left[{ }^{3} \mathrm{H}\right]$-timidina. Para todas as análises estatísticas foi considerado p $<0,05$. * quando comparado ao grupo salina; $\$$ quando comparado ao grupo vetor; \# quando comparado ao grupo pVAXhsp65. Resultado representativo de um experimento com n de 6 a 9. Índice=contagem por minuto das células estimuladas/contagem por minuto das células sem estímulo.

A figura 55 mostra a proliferação dos linfócitos dos animais imunizados com as diferentes construções vacinais. Os resultados foram apresentados em índice que refletem a proliferação das células estimuladas divida pela proliferação basal na ausência de estímulo. As células estimuladas com o mitógeno ConA (Figura 55A) proliferaram em todos os animais independente da imunização, indicando que se ocorressem variações com os estímulos específicos não seria devido a problemas com as células. As células dos animais imunizados com as vacinas pVAXhsp65, pVAXgDVac1PA, pVAXgDVac1AA e pVAXgDVac2, quando 
estimuladas com a proteína recombinante Hsp65 proliferaram (Figura 55B), sugerindo a presença de linfócitos T específicos para peptídeos dessa proteína.

As células dos animais vacinados com pVAXgDVac1PA, pVAXgDVac1AA e pVAXgDVac2 também foram capazes de proliferar quando estimuladas com as proteínas Vac1 e Vac2 (Figura 55C e D) que são os estímulos específicos dessas vacinas. No entanto, as células dos animais imunizados com a vacina pVAXhsp65 não foram capazes de responder frente a esses dois estímulos. As vacinas pVAXgDVac1PA, pVAXgDVac1AA e pVAXgDVac2 demonstraram ainda uma tendência maior de proliferação quando comparadas a vacina $\mathrm{pVAXhsp65.}$

\subsubsection{Fenótipo celular: células $\mathrm{CD4}^{+}$e $\mathrm{CD8}^{+}$}

Os linfócitos do baço dos animais imunizados foram avaliados quanto ao fenótipo celular $\mathrm{CD}^{+}$(Figura 56) e $\mathrm{CD}^{+}$(Figura 57) por citomeria de fluxo após 30 dias da última imunização. Essas células foram primeiramente estimulados ex vivo por 48 horas com ConA ou com as proteínas recombinantes Hsp65, Vac1 e Vac2. Em seguida avaliadas em relação as características fenotípicas. Como controle negativo foi utilizado células tratadas apenas com meio de cultura. 


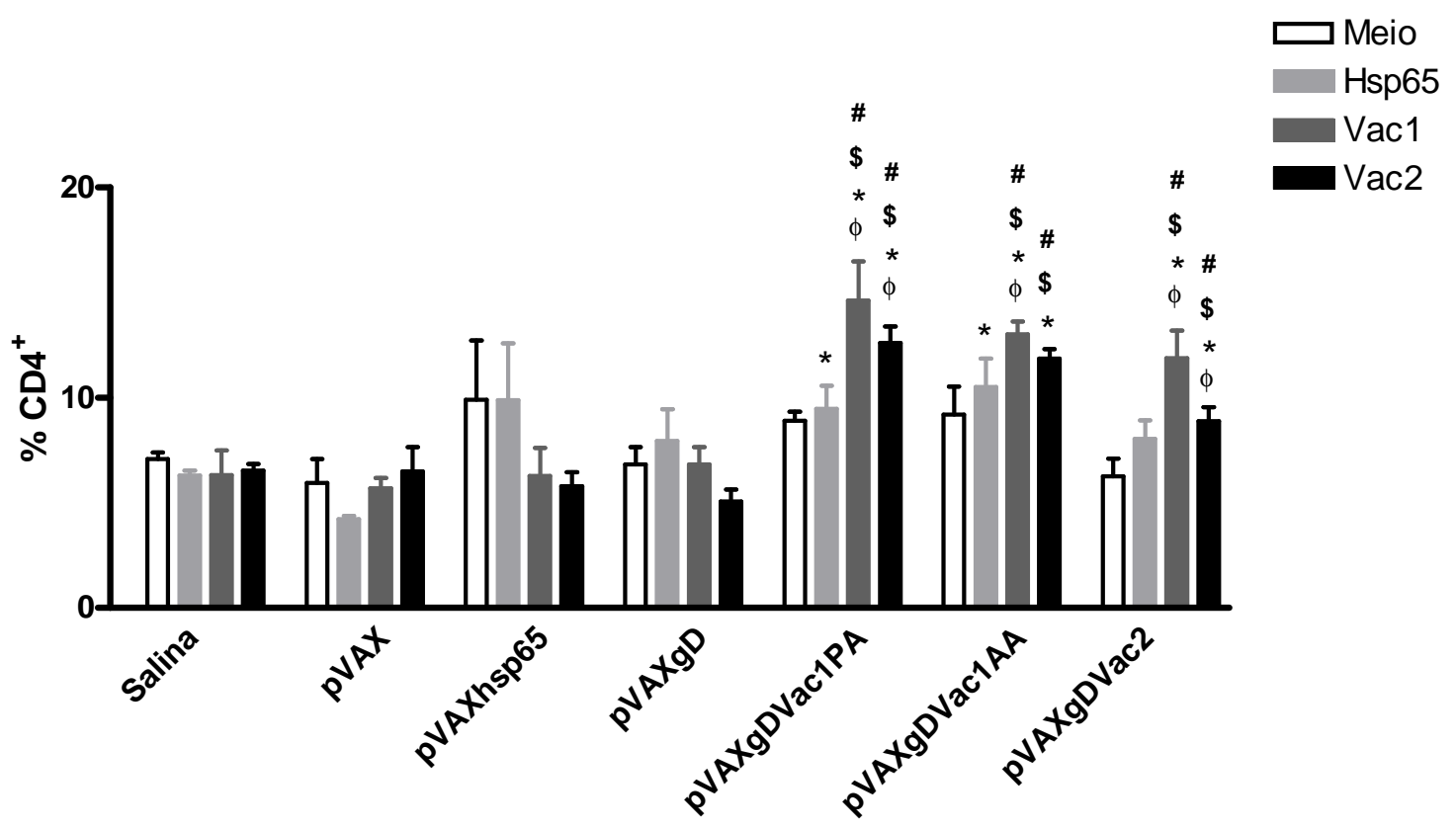

Figura 56: Porcentagem de células T CD4 $^{+}$. Células do baço foram estimuladas ex vivo por 48 horas e o fenótipo celular avaliado por citometria de fluxo. Para todas as análises estatísticas foi considerado $\mathrm{p}<0,05$. $\Phi$ quando comparado ao meio (diferença entre a porcentagem de células iniciais e após a estimulação); * quando comparado ao grupo salina; \$ quando comparado ao grupo vetor; \# quando comparado ao grupo pVAXhsp65. Resultado representativo de um experimento com $n=5$.

A figura 56 demonstra que todos os grupos apresentavam porcentagem semelhante de células $\mathrm{T} \mathrm{CD}^{+}$totais quando não estimulados. Com relação ao estímulo Hsp65, os grupos não apresentaram diferenças significativas na porcentagem de células quando comparados a ausência de estímulo, mas houve um aumento na quantidade de células T CD4+ após a adição da proteína Hsp65 nos grupos imunizados com pVAXgDVac1PA e pVAXgDVac1AA quando comparados ao grupo salina.

Além disso, a porcentagem de células $\mathrm{T} \mathrm{CD}^{+}$foi maior nos animais vacinados com as três construções vacinais pVAXgDVac1PA, pVAXgDVac1AA e pVAXgDVac2 quando estimulados com as proteínas específicas Vac1 e Vac2 e comparados a ausência de estímulo e aos grupos imunizados com salina, pVAXgD e pVAXhsp65. Esses resultados demonstram que os animais imunizados com as vacinas pVAXgDVac1PA, pVAXgDVac1AA e 
pVAXgDVac2 foram capazes de gerar maior porcentagem de linfócitos $\mathrm{T} \mathrm{CD}^{+}$quando comparadas aos animais vacinados com pVAXhsp65.

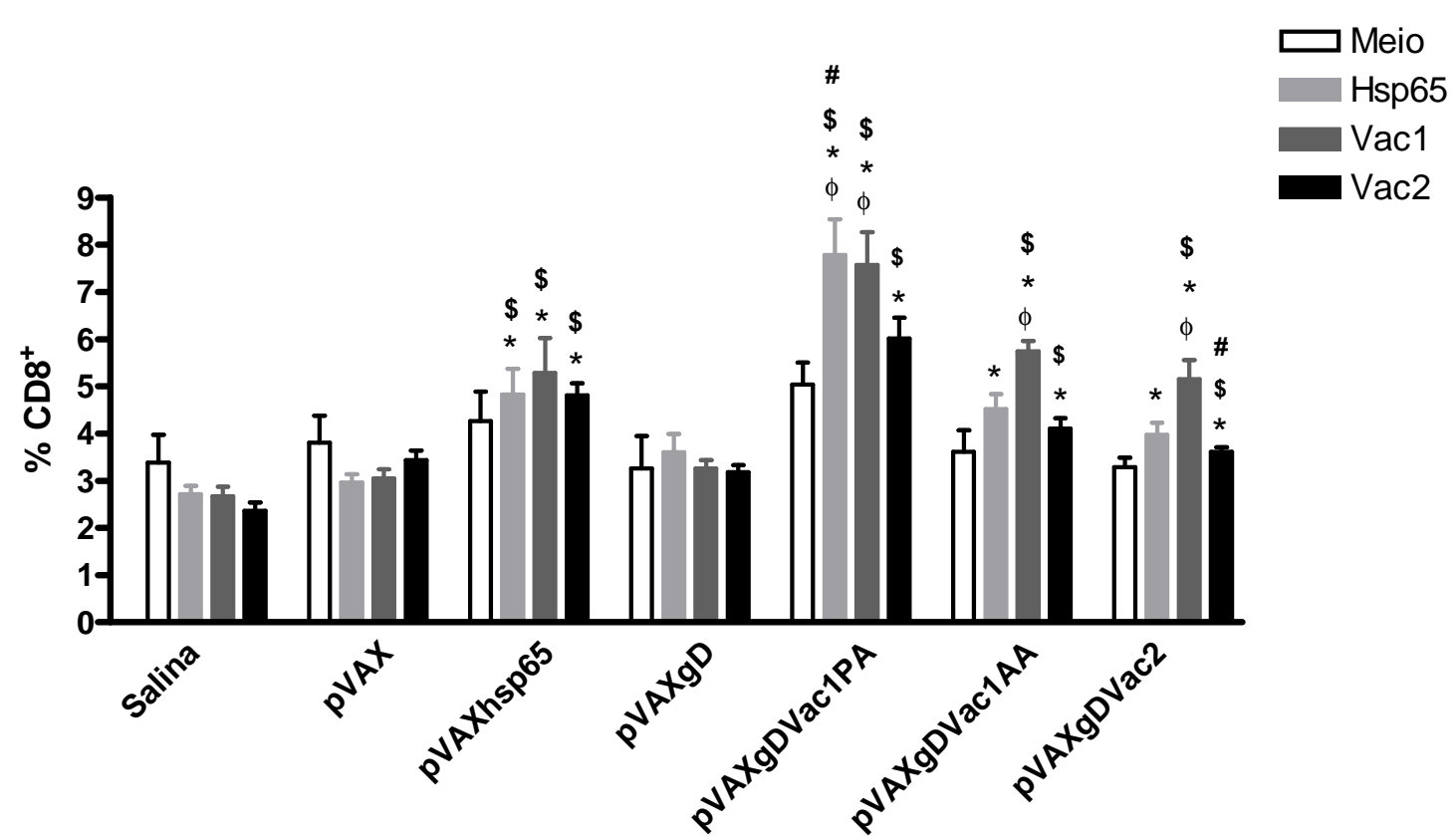

Figura 57: Porcentagem de células T CD8 ${ }^{+}$. Células do baço foram estimuladas ex vivo por 48 horas e o fenótipo celular avaliado por citometria de fluxo. Para todas as análises estatísticas foi considerado $\mathrm{p}<0,05$. $\Phi$ quando comparado ao meio (diferença entre a porcentagem de células iniciais e após a estimulação); * quando comparado ao grupo salina; \$ quando comparado ao grupo vetor; \# quando comparado ao grupo pVAXhsp65. Resultado representativo de um experimento com $n=5$.

Com relação as células $\mathrm{T} \mathrm{CD}^{+}$, a figura 57 demonstra que todos os grupos apresentavam porcentagem semelhante dessas células quando não estimulados. Com relação ao estímulo Hsp65 apenas o grupo pVAXgDVac1PA apresentou diferenças significativas na porcentagem de células quando comparados a ausência de estímulo. No entanto, foi observado um aumento na porcentagem de células $\mathrm{T} \mathrm{CD}^{+}$após a adição da proteína Hsp65 nesse grupo e nos animais imunizados com pVAXhsp65, pVAXgDVac1AA e pVAXgDVac2 quando comparados ao grupo salina.

A porcentagem de células $\mathrm{T} \mathrm{CD}^{+}$também foi maior nos animais vacinados com pVAXgDVac1PA, pVAXgDVac1AA e pVAXgDVac2 quando estimulados com a proteína Vac1 e comparados com a ausência de estímulo. Além disso, esse estímulo e a proteína Vac2 induziram um aumento na porcentagem de células $\mathrm{T} \mathrm{CD}^{+}$nos grupos pVAXhsp65, 
pVAXgDVac1PA, pVAXgDVac1AA e pVAXgDVac2, quando comparados com os animais imunizados com salina e vetores.

Esses resultados demonstram que os animais imunizados com as quatro vacinas pVAXhsp65, pVAXgDVac1PA, pVAXgDVac1AA e pVAXgDVac2 foram capazes de gerar maior porcentagem de linfócitos $\mathrm{T} \mathrm{CD}^{+}$com uma tendência de maior indução dessas células pela vacina $\mathrm{pVAXgDVac1PA.}$

\subsubsection{Produção de citocinas}

A produção das citocinas IFN- $\gamma$ (Figura 58), IL-2 (Figura 59), IL-12, IL-5 e IL-10 pelos linfócitos foi avaliada no sobrenadante de cultura de células do baço dos animais imunizados após 30 dias da última imunização. Essas células foram estimuladas ex vivo por 48 horas com ConA ou com as proteínas recombinantes Hsp65, Vac1 e Vac2. As citocinas foram quantificadas por ELISA no sobrenadane das culturas. Como controle negativo foi utilizado sobrenadante de células não estimuladas. 

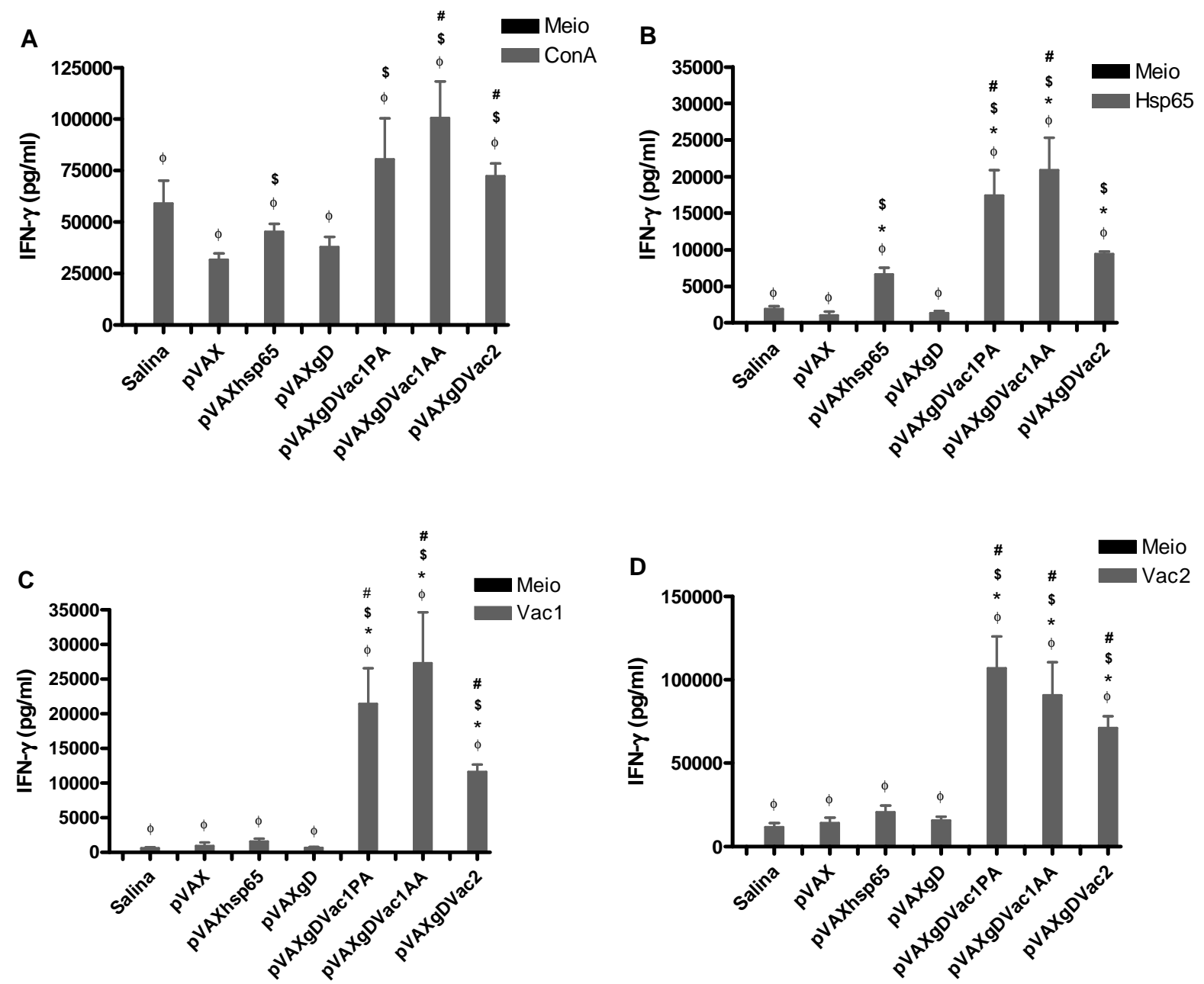

Figura 58: Produção de IFN- $\boldsymbol{\gamma}$. A) Cultura estimulada com ConA, B) proteína Hsp65; C) proteína Vac1 e D) proteína Vac2. Células do baço foram estimuladas ex vivo por 48 horas e a produção de IFN- $\gamma$ quantificada por ELISA no sobrenadante da cultura. Para todas as análises estatísticas foi considerado $p<0,05$. $\Phi$ quando comparado ao controle negativo (ausência de reestimulo); * quando comparado ao grupo salina; \$ quando comparado ao grupo vetor; \# quando comparado ao grupo pVAXhsp65. Resultado representativo de um experimento com n de 6 a 9 .

As células quando estimuladas com ConA produzem alta quantidade de IFN- $\gamma$ independente da vacina utilizada (Figura 58A). As células dos animais imunizados com as vacinas pVAXhsp65, pVAXgDVac1PA, pVAXgDVac1AA e pVAXgDVac2 quando estimuladas com a proteína recombinante Hsp65 produziram IFN- $\gamma$ (Figura 58B). Esse resultado sugere a presença de linfócitos $\mathrm{T}$ específicos para peptídeos dessa proteína, produtores de IFN- $\gamma$, nos animais imunizados com essas vacinas. 
Os animais vacinados com pVAXgDVac1PA, pVAXgDVac1AA e pVAXgDVac2 também foram capazes de responder produzindo IFN- $\gamma$ quando suas células foram estimuladas com as proteínas Vac1 e Vac2 (Figura 58C e D) que são os estímulos específicos dessas vacinas. No entanto, as células dos animais imunizados com a vacina pVAXhsp65 não foram capazes de responder frente a esses dois estímulos. Além disso, as vacinas pVAXgDVac1PA, pVAXgDVac1AA e pVAXgDVac2 foram capazes de induzir uma melhor resposta de linfócitos T produtores de IFN- $\gamma$ quando comparadas a vacina pVAXhsp65 para todos os estímulos.
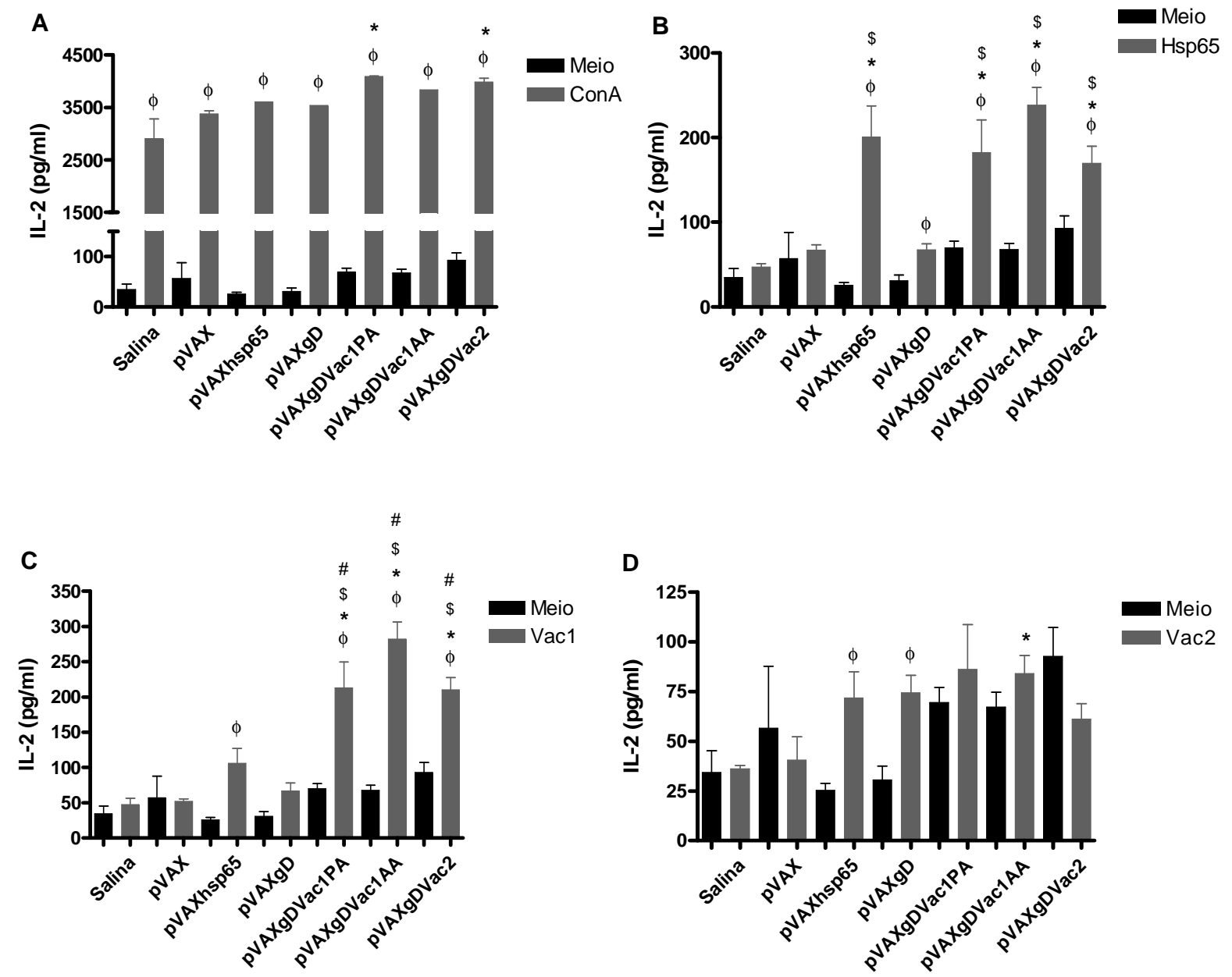

Figura 59: Produção de IL-2. A) Cultura estimulada com ConA, B) proteína Hsp65, C) proteína Vac1 e D) proteína Vac2. Células do baço foram estimuladas ex vivo por 48 horas e a produção de IL-2 quantificada por ELISA no sobrenadante da cultura. Para todas as análises estatísticas foi considerado $p<0,05$. $\Phi$ quando comparado ao controle negativo (ausência de reestimulo) * quando comparado ao grupo salina; \$ quando comparado ao grupo vetor; \# quando comparado ao grupo pVAXhsp65. Resultado representativo de um experimento com n de 6 a 9 . 
A figura 59 mostra a produção de IL-2 pelas células do baço dos animais imunizados com as diferentes construções vacinais. As células estimuladas com ConA produzem alta quantidade da citocina IL-2 independente da vacina utilizada (Figura 59A). As células dos animais imunizados com as vacinas pVAXhsp65, pVAXgDVac1PA, pVAXgDVac1AA e pVAXgDVac2 quando estimuladas com a proteína recombinante Hsp65 produziram IL-2 (Figura 59B) indicando a presença de linfócitos T específicos para peptídeos dessa proteína nos animais imunizados com essas vacinas.

Os animais vacinados com pVAXgDVac1PA, pVAXgDVac1AA e pVAXgDVac2 também foram capazes de responder produzindo IL-2 quando suas células foram estimuladas com as proteínas Vac1 (Figura 59C) que é um estímulo específico para essas vacinas. No entanto, esses mesmos grupos não foram capazes de responder ao estímulo Vac2 (Figura 59D) que também é específico para essas vacinas. Além desses resultados, as células dos animais imunizados com a vacina pVAXhsp65 não foram capazes de responder frente a esses dois estímulos.

Em relação a citocina IL-12 todos os grupos apresentaram baixa produção sem diferença significativa entre os grupos. Ao contrário, as citocinas IL-5 e IL-10 não foram detectadas nos diferentes grupos, exceto nas células estimuladas com ConA, que induziu a produção de ambas as citocinas (dados não mostrados).

\subsubsection{Fenótipo celular: células de memória}

Para cada grupo vacinado também foi avaliado o fenótipo celular relacionado aos marcadores CD44 e CD62L que podem indicar a presença de células de memória. Essas células também foram provenientes do baço dos animais imunizados depois de estimuladas ex vivo com as proteínas recombinantes Hsp65, Vac1 e Vac2. As figuras 60 e 61 são dot plots representativos de cada grupo experimental demonstrando a porcentagem de células de memória $\mathrm{CD}^{+}$e $\mathrm{CD} 8^{+}$, respectivamente. 
$\mathbf{E}$

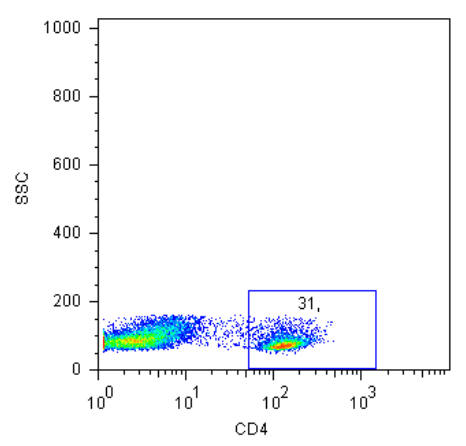

F

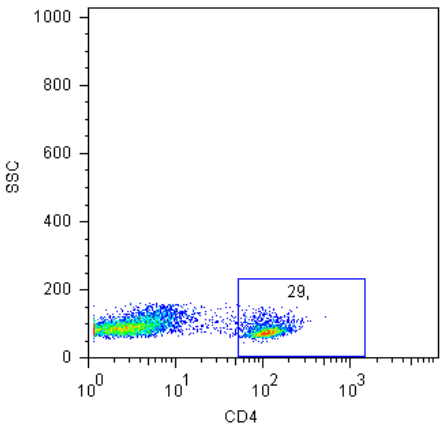

$\mathbf{G}$

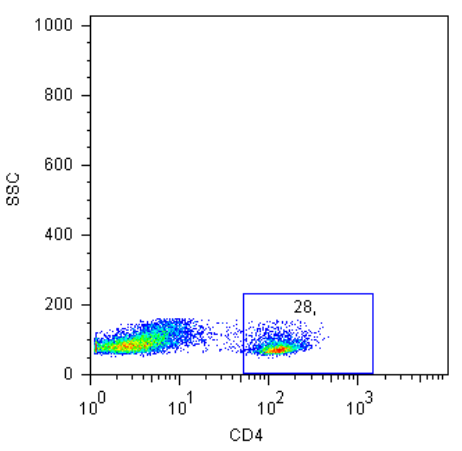

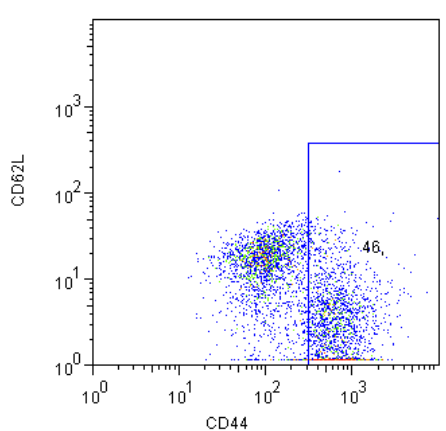
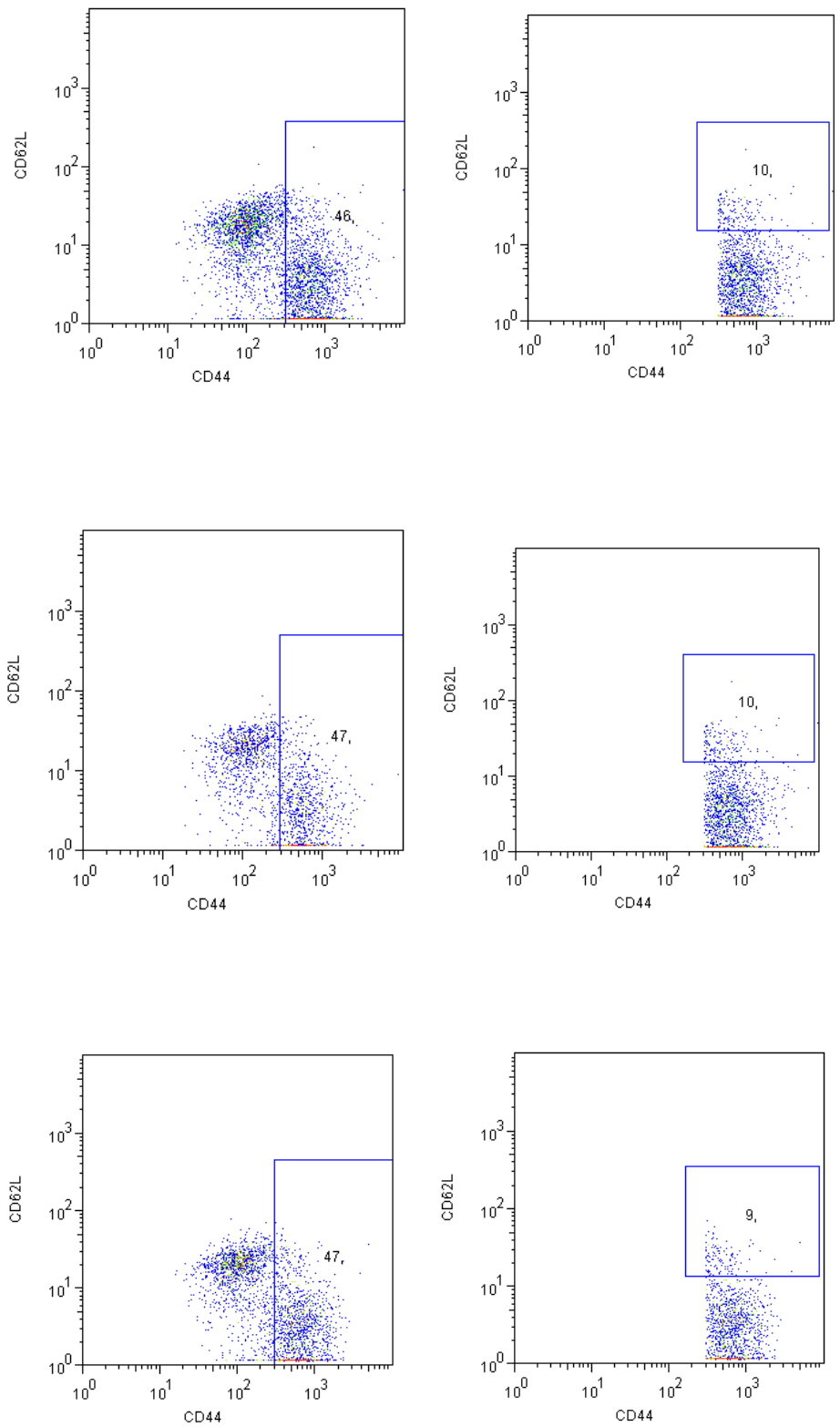

Figura 60: Porcentagem de células $T \mathrm{CD4}^{+}$de memória $\left(\mathrm{CD}_{4}{ }^{\text {hi }} \mathrm{CD62}^{+}\right)$. Células do baço foram estimuladas ex vivo por 48 horas com as proteínas recombinantes e o fenótipo celular avaliado por citometria de fluxo. Resultado representativo de cada grupo experimental estimulado com Vac1, A) Salina, B) pVAX, C) pVAXhsp65, D) pVAXgD, E) pVAXgDVac1PA, F) pVAXgDVac1AA e G) pVAXgDVac2. 1 gráfico - SSC (eixo y) X CD4 $4^{+}$(eixo x), 2ำ- CD62L X CD44, 3ํ- CD62L X CD44. 


\section{$\mathbf{E}$}
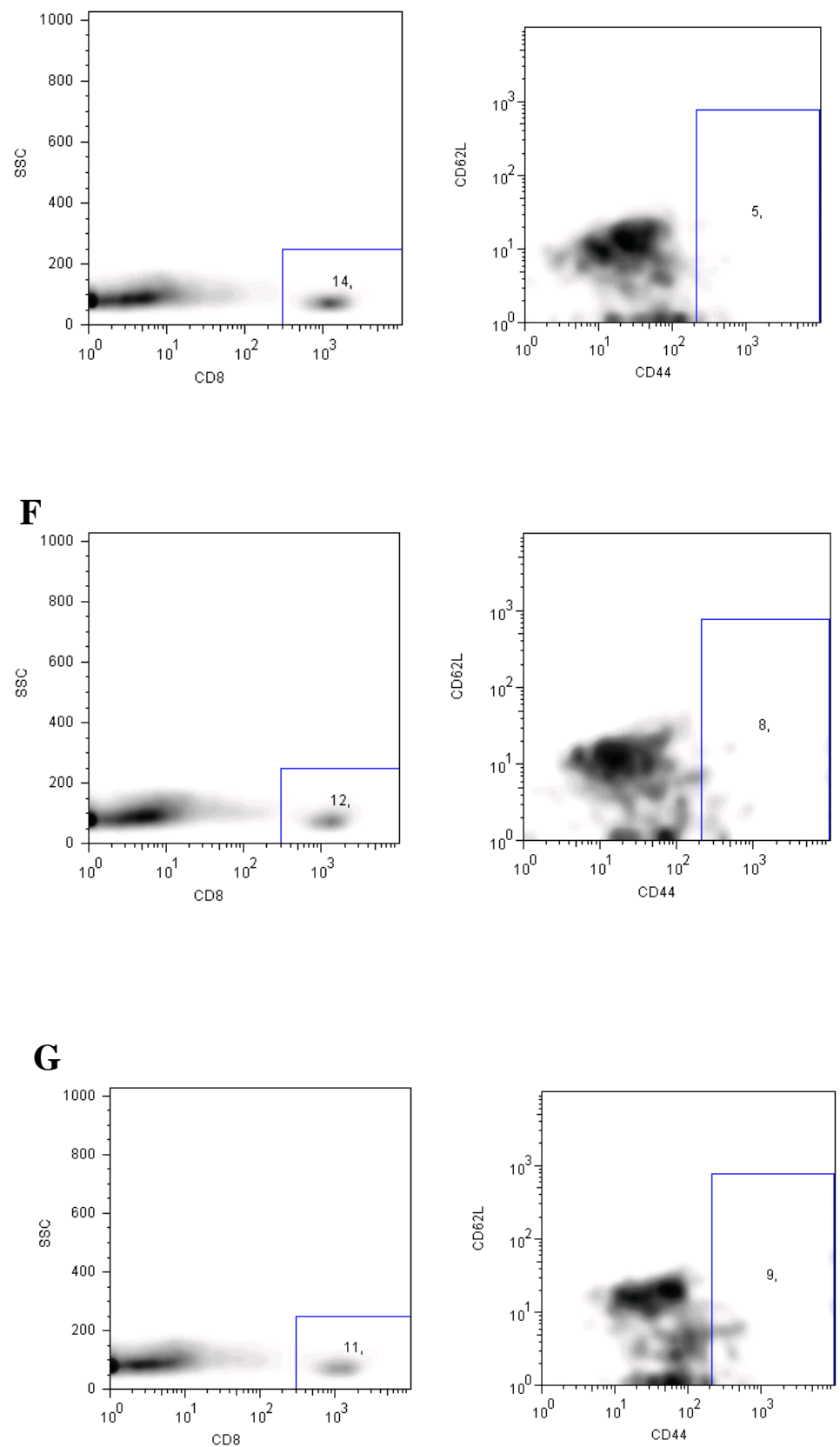
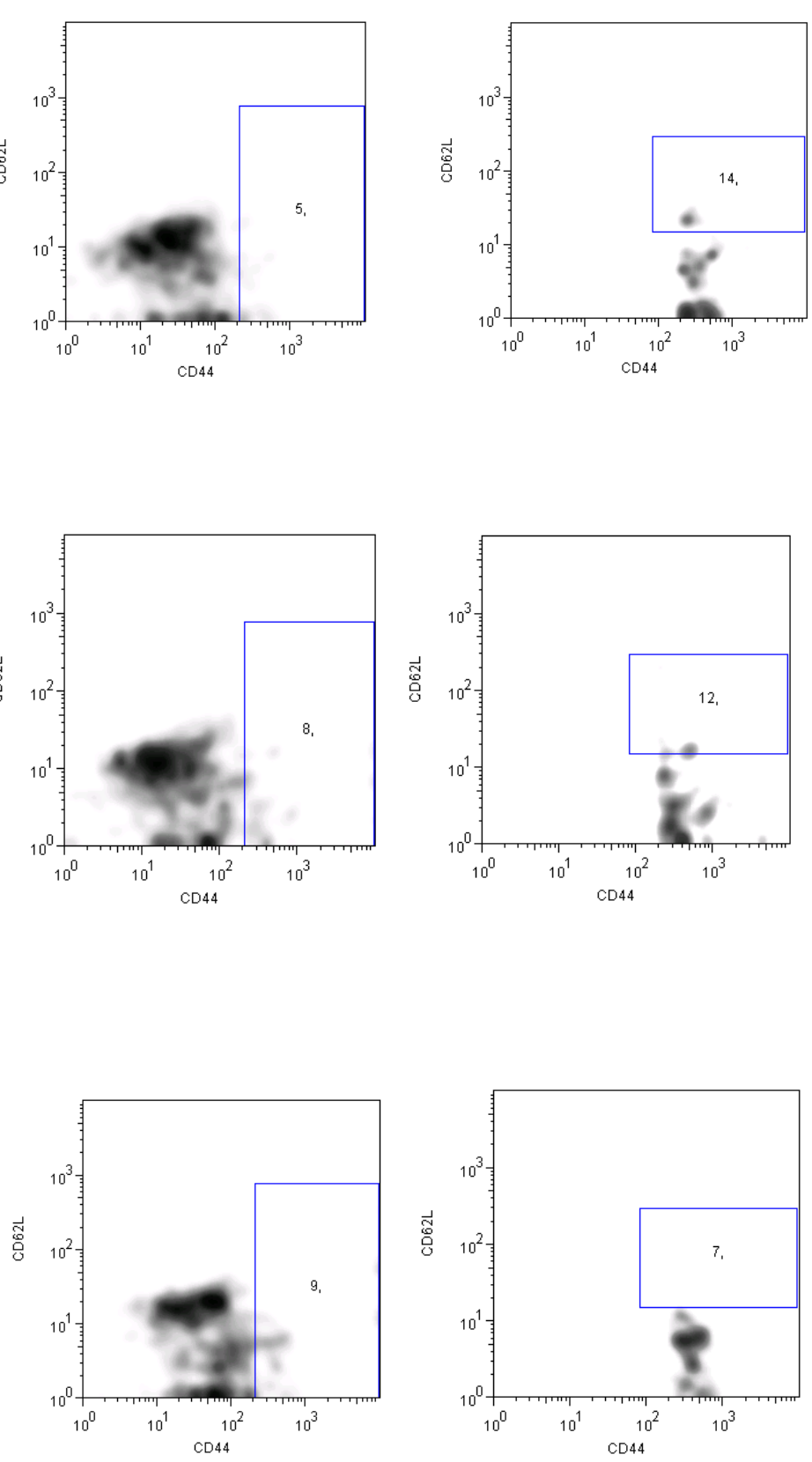

Figura 61: Porcentagem de células $\mathrm{T} \mathrm{CD8}^{+}$de memória $\left(\mathrm{CD}^{4} 4^{\mathrm{hi}} \mathrm{CD}^{\mathrm{C}} \mathrm{CL}^{+}\right)$. Células do baço foram estimuladas ex vivo por 48 horas com as proteínas recombinantes e o fenótipo celular avaliado por citometria de fluxo. Resultado representativo de cada grupo experimental estimulado com Vac2, A) Salina, B) pVAX, C) pVAXhsp65, D) pVAXgD, E) pVAXgDVac1PA, F) pVAXgDVac1AA e G) pVAXgDVac2. $1^{\circ}$ gráfico - SSC (eixo y) $\mathrm{X} \mathrm{CD}^{+}$(eixo x), $2^{\circ}-$ CD62L X CD44, $3^{\circ}-$ CD62L X CD44.

A análise de células de memória foi difícil de ser realizada devido ao pequeno número de células existentes nessa população e da variação dentro de cada grupo. Essas variações foram verificadas em todos os grupos que apresentaram porcentagens semelhantes de células 
de memória. No entanto, diante desses resultados a analise não nos gerou dados conclusivos. As figuras 60 e 61 são dot plots representativos de cada grupo experimental estimulados com as proteínas recombinantes Vac1 e Vac2, respectivamente. As análises demonstraram semelhante porcentagem de células de memória $\mathrm{CD}^{+}$e $\mathrm{CD}^{+}$para todos os grupos experimentais. 


\subsection{DISCUSSÃO}

Os maiores sucessos na vacinologia têm sido alcançados por meio da produção de anticorpos protetores, no entanto, o maior desafio dos vacinologistas e imunologistas frente a doenças como a AIDS, malária e TB é o desenvolvimento de uma imunidade celular protetora (Plotkin, 2005). Frente a esse desafio novas estratégias vêm sendo desenvolvidas como novos vetores, DNA plasmideais e carreadores capazes de induzir resposta de linfócitos $\mathrm{T} C \mathrm{C} 4^{+}$e $\mathrm{T}$ $\mathrm{CD}^{+}$(Plotkin, 2005). Além disso, várias estratégias também têm utilizado "substâncias" (adjuvantes, citocinas ou mesmo proteínas como a gD) capazes de direcionar a resposta para um padrão Th1 requerido em muitas doenças como as citadas anteriormente (Moingeon, Haensler et al., 2001) e capazes de estimular a imunidade inata (Plotkin, 2005), muito importante no direcionamento da imunidade adaptativa.

Nosso grupo vem trabalhando com a vacina DNAhsp65 que carrega o gene que codifica a proteína de choque térmico de $65 \mathrm{kDa}$ de $M$. leprae, mostrando que esse produto é eficiente na profilaxia da TB. A vacina já foi utilizada isoladamente ou em associação com microesferas e adjuvantes que diminui a quantidade de DNA administrado, demonstrando eficácia na proteção de camundongos e cobaias (Lowrie, Silva et al., 1997; Lima, Santos et al., 2003; De Paula, Silva et al., 2007). Os novos estudos continuam demonstrando a eficácia dessa vacina na profilaxia da TB e vêm sendo realizados com o intuito de aperfeiçoá-la para o uso clínico. Assim trabalhos mais recentes demonstram a eficácia da vacina DNAhsp65 quando administrada juntamente com BCG na estratégia de "prime-boost" (Goncalves, Bonato et al., 2007; Souza, Zarate-Blades et al., 2008) e quando em associação com lipossoma reduzindo a dose de DNA em 16 vezes (Rosada, De La Torre et al., 2008; Souza, Zarate-Blades et al., 2008). Além de eficaz na profilaxia, essa vacina também atua nos casos crônicos de TB, na doença disseminada, na TB latente e na TB-MDR (Lowrie, Tascon et al., 1994; Lowrie, Tascon et al., 1999; Silva, Bonato et al., 2005). 
Nesse contexto o objetivo desse trabalho foi a construção de vacinas de DNA para a profilaxia da TB utilizando-se epitopos da proteína Hsp65 do M. leprae que ativam células T $\mathrm{CD}^{+}$e $\mathrm{T} \mathrm{CD} 8^{+}$. Apesar dos resultados promissores com a vacina DNAhsp65, a utilização de apenas a parte responsável pela estimulação dos linfócitos $\mathrm{T}$ da proteína Hsp65 é uma estratégia promissora devido a similaridade com a equivalente proteína de mamíferos (Hsp60) (Feige e Van Eden, 1996). Trabalhos do grupo já demonstraram que a vacina DNAhsp65 não acarreta auto-lesão tecidual nem agravamento de doenças como artrite e diabetes (SantosJunior, Sartori et al., 2005; Lima, 2006; Santos Junior, Sartori et al., 2007), no entanto, uma formulação vacinal baseada apenas na utilização dos epítopos que são reconhecidos pelas células T e que não estão na região de grande homologia entre a Hsp65 de micobactérias e a humana seria viável na otimização da vacina já existente.

Além disso, os epitopos estariam associados a glicoproteína D do vírus do herpes tipo 1 que estimula a resposta imunológica humoral e celular (Lasaro, Alves et al., 2003; Lasaro, Diniz et al., 2005; Lasaro, Tatsis et al., 2008). A idéia de desenvolver vacinas associadas a "substâncias" capazes de estimular uma resposta imunológica é viável para as vacinas de DNA que podem conter diferentes genes em um mesmo plasmideo.

O primeiro passo desse projeto foi a construção das vacinas utilizando-se técnicas de biologia molecular. Como seriam construções utilizadas na vacinação de camundongos tomou-se todos os cuidados para que fossem construídas de forma a produzirem corretamente as proteínas quando utilizadas nas imunizações.

As sequiências que codificam os epitopos da proteína Hsp65 (Mustafa, Lundin et al., 1999; Charo, Geluk et al., 2001) utilizadas nesse trabalho estavam distribuídas dentro da seqüência do gene hsp65 em diferentes sítios, dessa forma, foi necessário primeiro a construção do molde Vac1 (5 epitopos da proteína Hsp65) por meio de uma síntese gênica utilizando a reação em cadeia da polimerase e primers que cobrissem toda a seqüência Vac1. 
Após a obtenção desse molde foi possível construir os três fragmentos utilizados nesse

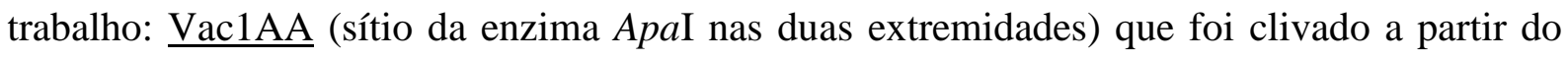
molde Vac1 com a enzima ApaI, $\underline{\text { Vac1PA }}$ (sítio das enzimas PvuII e ApaI nas extremidades 5' e 3', respectivamente) que foi amplificado com primers específicos contendo os sítios da

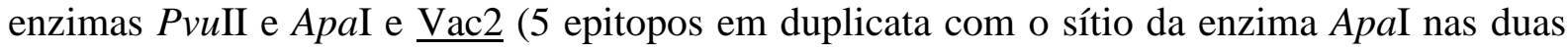
extremidades) gerado por duas amplificações e ligação dos fragmentos. Essas seqüências foram utilizadas juntamente com os vetores pRE4 e pVAX1 nas construções vacinais.

Os fragmentos Vac1AA e Vac1PA são idênticos exceto pelo local no interior da proteína $\mathrm{gD}$ onde foram inseridos, o primeiro foi inserido no interior da $\mathrm{gD}$ sem a retirada de nenhum fragmento desse gene e o segundo no interior da $\mathrm{gD}$, com a retirada de um porção central desse gene próxima ao sítio de ligação da gD com seu receptor. Essa construção foi realizada para avaliar se essa porção seria importante nos efeitos imunomoduladores da proteína gD. O fragmento Vac2 é duas vezes a Vac1 e foi construído para verificar se uma maior quantidade do antígeno melhoraria a resposta, uma vez que mais antígeno poderia significar maior apresentação pelas APCs e, dessa forma, melhor ativação de clones de linfócitos T.

O vetor pRE4 foi utilizado por ser o plasmídeo que apresenta a seqüência de nucleotídeos responsável pela expressão da proteína gD (Cohen, Wilcox et al., 1988). A gD apresenta sítios únicos de restrição para as enzimas $P v u I I$ e $A p a \mathrm{I}$ onde podem ser inseridos os fragmentos de interesse, e está flanqueada pelo sítio de restrição da enzima HindIII podendo ser retirada desse vetor e clonada em outro.

As três sequiências, Vac1AA, Vac1PA e Vac2, foram clonadas no vetor pRE4, da seguinte forma: Vac1AA e Vac2 foram clonadas no pRE4 clivado com a enzima ApaI de forma que esses fragmentos fossem inseridos após o aminoácido 269 da proteína gD; Vac1PA 
foi clonada no pRE4 clivado com as enzimas PvuII e ApaI que promove a retirada de 214 aminoácidos (aas) da gD (retirada dos aas 54 ao 267).

Lasaro e colaboradores (2008) demonstraram que a inserção de genes no interior da gD no sítio da enzima ApaI não prejudicava a interação dessa proteína com seu receptor HVEM, no entanto, não se sabe se a inserção entre $P v u I I$ e ApaI pode prejudicar essa interação. A gD interage com seu receptor HVEM por meio de aas presentes no N-terminal (aas 11, 15, 25, 27, 28, 29 e 30) (Lasaro, Tatsis et al., 2008) que não são retirados com nenhuma das clivagens, por isso qualquer alteração na interação HVEM-gD é devido a mudanças conformacionais em ambas as construções, $P v u \mathrm{II}$ e ApaI ou somente em ApaI.

A confirmação das clonagens foi realizada por PCR e análise de restrição. Foram utilizados primers e enzimas que pudessem confirmar a direção e quantidade de inserto uma vez que duas das clonagens, Vac1AA e Vac2, foram realizadas com a utilização de apenas uma enzima, ApaI. Em seguida, as seqüências gDVac1AA, gDVac1PA e gDVac2 foram transferidas ao vetor $\mathrm{pVAX} 1$.

O pVAX1 é um vetor plasmidial usado no desenvolvimento de vacinas de DNA e tem sido utilizado em ensaios clínicos em humanos como é o caso do próprio ensaio clínico com a vacina DNAhsp65 (Michaluart, Abdallah et al., 2008). Esse vetor apresenta o promotor do citomegalovírus humano (CMV) para eficiente expressão em células de mamíferos, possui um sinal de poliadenilação para eficiente terminação da transcrição e poliadenilação do RNA mensageiro e o gene de resistência ao antibiótico canamicina para seleção em E. coli. As clonagens dos fragmentos no vetor pVAX1 resultaram na construção das vacinas pVAXgDVac1AA, pVAXgDVac1PA e pVAXgDVac2 que foram confirmadas por PCR, análise de restrição e seqüenciamento.

Além das construções descritas acima foi construído também o plasmídeo controle pVAXgD, com a retirada da gD do vetor pRE4 com a enzima HindIII e clonagem no pVAX1. 
Apesar de termos montado essa vacina $\mathrm{pVAXgD}$ todas as outras construções que envolvem a fusão da seqüência dos epitopos a gD foram realizadas pela clonagem no vetor pRE4, pois como o pVAX1 possui em seu sítio de múltipla clonagem o sítio da enzima Apa que foi utilizada em todas as nossas demais construções para fusionar os epitopos no interior da gD, se esse vetor fosse clivado com essa enzima não seria apenas linearizado e sim liberaria um fragmento prejudicando as construções.

Além da utilização das seqüências gênicas Vac1 e Vac2 na construção de vacinas de DNA, essas seqüências também foram utilizadas na expressão das proteínas Vac1 e Vac2 em sistema procarioto uma vez que essas proteínas seriam necessárias para a produção de anticorpos anti-Vac1 e anti-Vac2 úteis na caracterização da expressão das proteínas das vacinas construídas. O sistema procarioto (E. coli) foi utilizado na expressão das proteínas por ser um sistema fácil, barato e por não haver a preocupação da necessidade de modificações pós-traducionais uma vez que essas proteínas são montadas, não apresentam uma conformação organizada, nem função a não ser a de epitopos de células T.

Inicialmente foi realizado um teste induzindo a expressão das proteínas de interesse por três diferentes tempos, uma vez que essa é uma variável importante na obtenção de grande quantidade de proteínas recombinantes. As variáveis que podem ser utilizadas além do tempo são a quantidade de indutor e a temperatura, essas foram fixadas em nossos experimentos em 0,2 $\mathrm{mM}$ de indutor e $37^{\circ} \mathrm{C}$ para não prejudicar a expressão da proteína com muito indutor e para aproveitar a temperatura melhor de crescimento da E. coli. Os nossos resultados mostram que a expressão por 4 horas foi melhor que 3 horas, mas a expressão por 16 horas não induziu uma maior quantidade de proteína. Um resultado esperado, pois longos períodos de indução requerem diminuição da temperatura para que a bactéria cresça devagar, produza a proteína e não consuma todos os nutrientes do meio, necessários a sua sobrevivência. 
Após a expressão, as proteínas foram avaliadas quanto a solubilidade. No processo de expressão de proteínas recombinantes em E. coli muitas vezes as proteínas ficam insolúveis devido a formação de agregados protéicos inativos conhecidos como corpos de inclusão (Baneyx e Mujacic, 2004; Jevsevar, Gaberc-Porekar et al., 2005). Isso ocorre devido ao dobramento incorreto da proteína ocasionado pela maquinária procariota não possuir mecanismos de modificações pós-traducionais, devido aos fortes promotores e a alta quantidade de indutor utilizado fazendo com que a expressão exceda $50 \%$ do total das proteínas bacterianas (Baneyx e Mujacic, 2004; Jevsevar, Gaberc-Porekar et al., 2005). Dessa forma, a proteína fica indisponível para a purificação sendo necessária a desnaturação. A avaliação da solubilidade das proteínas Vac1 e Vac2 mostraram que elas foram expressas na forma solúvel, mas parte delas permaneceu no sedimento celular o que pode ter ocorrido devido a essas proteínas serem montados e não apresentarem uma conformação ordenada. Para obtermos um rendimento melhor optamos por fazer a lise desnaturante com adição de uréia e mais passos de sonicação.

Após a expressão e solubilização das proteínas, estas foram purificadas por cromatografia de afinidade. Essas proteínas foram expressas em fusão com uma cauda de histidina (6 aminoácidos histidina presente no vetor de clonagem) o que facilita a purificação. Esse aminoácido apresenta o grupo imidazol que possui afinidade ao níquel imobilizado na coluna cromatográfica, dessa forma, as proteínas ficam retidas na coluna e são eluídas utilizando diferentes concentrações de imidazol. Os resultados mostraram que a purificação por cromatografia de afinidade foi eficiente em purificar as proteínas Vac1 e Vac2. Essas proteínas foram eluídas nas frações de $150 \mathrm{mM}$ de imidazol que não é uma quantidade muito alta de competidor. Isso pode indicar a "afinidade média" dessas proteínas provavelmente pelo tamanho pequeno e pela ausência de histidinas em sua sequiência. No entanto, esse não foi um fator limitante para a purificação e as frações puras foram dialisadas para retirada da 
uréia e imidazol e as proteínas utilizadas na imunização de camundongos para obtenção dos anticorpos anti-Vac1 e anti-Vac2 e nos ensaios de imunogenicidade.

A lise com uréia provoca desnaturação das proteínas e o processo de diálise pode reverter algumas moléculas de proteínas para a conformação normal, no entanto, podem permanecer proteínas desnaturadas. Uma preocupação quanto a isso foi dos anticorpos gerados pelas imunizações com as vacinas pVAXgDVac1AA, pVAXgDVac1PA e pVAXgDVac2 não reconhecerem as proteínas nos ensaios de avaliação da resposta humoral por terem sido gerados para proteínas quiméricas gDVac1AA, gDVac1PA e gDVac2 cuja conformação pode exibir epitopos conformacionais ausentes nas proteínas Vac1 e Vac2 desnaturadas. No entanto, isso ocorreu apenas para uma das construções e será discutido mais adiante.

As proteínas Vac1 e Vac2 assim como as construções vacinais, pVAXgD, pVAXgDVac1AA, pVAXgDVac1AA e pVAXgDVac2 foram todas produzidas em E. coli, e uma das principais preocupações com relação à imunização com vacinas de DNA ou proteína é a contaminação com lipopolissacarídeos (LPS). O LPS é uma endotoxina presente na membrana das bactérias gram-negativas como a E. coli que pode "alterar" a imunogenicidade da vacina atuando como um adjuvante. Essa molécula é capaz de imunomodular APCs, promovendo a sua maturação, aumento na expressão de moléculas co-estimuladoras e liberação de citocinas que direcionam a resposta imunológica para um perfil Th1 (Hawkins, Trcka et al., 2003). Dessa forma, todas as construções vacinais e as proteínas expressas foram testadas para excluir a presença de contaminação pelo LPS. Essa análise demonstrou a pureza de todos os DNAs e das proteínas Vac1 e Vac2, os quais foram considerados aceitáveis para testes in vivo de acordo com a Farmacopéia Européia que preconiza que o limite de contaminação por endotoxina não ultrapasse 5UE/kg peso corpóreo/hora (Tuomela, Stanescu et al., 2005). 
As proteínas Vac1 e Vac2 foram, então, utilizadas na imunização de camundongos para obtenção de anticorpos policlonais anti-Vac1 e anti-Vac2. Os soros dos animais imunizados contendo esses anticorpos foram caracterizados para detectar se esses anticorpos reagiam cruzadamente com a proteína Hsp60 de mamíferos uma vez que células humanas HEK293 foram utilizadas nos ensaios de transfecções para caracterização das vacinas construídas. Essa é uma caracterização importante uma vez que as HSPs são proteínas altamente conservadas (Lindquist e Craig, 1988) e devido a proteína Hsp65 apresentar 55\% de similaridade com a equivalente proteína de mamíferos (Hsp60) (Feige e Van Eden, 1996).

O ensaio foi realizado com células HEK293 incubadas a $42^{\circ} \mathrm{C}$ simulando uma situação de estresse com intuito de aumentar a expressão da proteína Hsp60 e, em seguida, essas células foram submetidas ao protocolo de "Western blot" utilizando-se os anticorpos antiHsp60, anti-Vac1 e anti-Vac2. Apenas o anticorpo anti-Hsp60 foi capaz de reconhecer essa proteína, não havendo reação cruzada por parte dos anticorpos policlonais anti-Vac1 e antiVac2. Dessa forma, esses anticorpos puderam ser utilizados para detectar as proteínas expressas pelas vacinas construídas confirmando se a construção foi realizada corretamente.

Essa avaliação foi importante também pelo fato de constatar que anticorpos gerados contra as proteínas Vac1 e Vac2 são incapazes de reconhecer a proteína Hsp60 de mamíferos sugerindo a impossibilidade de geração de auto-imunidade pelos anticorpos gerados na imunização com as vacinas de DNA. A preocupação na possibilidade da vacina desencadear uma resposta auto-imune existe, pois há estudos que demonstraram resposta imunológica celular e humoral contra a Hsp65 bacteriana em modelos experimentais de diabetes (Elias, Reshef et al., 1991), ateroesclerose (Afek, George et al., 2000) e artrite (Danieli, Markovits et al., 1992). No entanto, trabalhos com a vacina DNAhsp65 demonstram essa preocupação e indicam que a vacina não desencadeia auto-imunidade, além de ser benéfica em modelo de 
artrite e diabetes (Santos-Junior, Sartori et al., 2005; Lima, 2006; Santos Junior, Sartori et al., 2007).

Após a obtenção e caracterização dos anticorpos policlonais as construções vacinais pVAXgD, pVAXgDVac1PA, pVAXgDVac1AA e pVAXgDVac2 foram avaliadas em relação a funcionalidade. Apesar de corretas em relação a seqüência, todas as construções vacinais foram utilizadas na transfecção de células HEK293 com intuito de verificar a formação de transcritos (RNA mensageiro) e da proteína codificadas por elas. Essa avaliação é de extrema importância nas construções de vacinas de DNA visto que resultados negativos podem ser devido a construções erradas que não codificam proteínas em sistema eucarioto. Algumas construções podem ser realizadas fora de fase aberta de leitura resultando na ausência de expressão ou produção de proteínas diferentes da nativa.

O vetor pVAX1 apresenta um sítio de múltipla clonagem de forma que as proteínas sejam traduzidas a partir do seu próprio ATG e finalizadas com seu próprio stop códon. Nas vacinas construídas esses códons estavam presentes na proteína gD e os insertos Vac1AA, Vac1PA e Vac2 foram todos clonados no interior dessa proteína na sua fase aberta de leitura como confirmado pelo seqüenciamento.

Os transcritos apresentaram os tamanhos esperados para a combinação de primers utilizada, confirmando a presença do RNA mensageiro para as construções vacinais realizadas. Todas as proteínas reveladas apresentaram um tamanho um pouco maior que o esperado provavelmente devido ao marcador de massa molecular não reproduzir fielmente o tamanho das proteínas ou a resolução do método. As proteínas estavam presentes no sedimento e sobrenadante celulares, isto é, tanto na fração insolúvel quanto na fração solúvel, respectivamente. Isso pode ser explicado pelo fato da gD ser uma glicoproteína que possui uma região transmembrana definida pelos aminoácidos 340 a 364 (Watson, Weis et al., 1982), dessa forma, a Vac1 ou Vac2 fusionadas a ela podem ser expressas na superfície das células 
transfectadas com os plasmídeos pVAXgDVac1AA, pVAXgDVac1PA e pVAXgDVac2 (Lasaro, Diniz et al., 2005; Lasaro, Tatsis et al., 2008) corroborando com a presença dessas proteínas nas porções insolúveis. As avaliações, portanto, mostraram que todas as vacinas construídas apresentaram seus "genes" transcritos e traduzidos.

Outro anticorpo utilizado para detectar a expressão das proteínas codificadas pelas vacinas foi o anti-gD que confirmou a expressão das proteínas gDVac1PA, gDVac1AA e gDVac2. Esse anticorpo também propiciou a caracterização da vacina $\mathrm{pVAXgD}$ o que não era possível com os anticorpos anti-Vac1 e anti-Vac2.

As construções vacinais, após toda caracterização, foram utilizadas nas imunizações de camundongos realizadas pela administração intramuscular de quatro doses com intervalo de 15 dias. Juntamente com as vacinas construídas foram utilizados o vetor pVAX e a vacina pVAXhsp65 desenvolvida em nosso laboratório. Apesar das críticas em relação a imunização intramuscular por ser um tecido "pobre" em células apresentadoras de antígenos essa é uma rota muito utilizada, pois trabalhos demonstram a expressão do gene nos miócitos (Wolff, Malone et al., 1990) bem como em células dendríticas (Casares, Inaba et al., 1997) e macrófagos (Chattergoon, Robinson et al., 1998), além da distribuição da vacina de DNA no sangue e vários outros tecidos, sendo, portanto, uma inoculação sistêmica (Winegar, Monforte et al., 1996; Coelho-Castelo, Trombone et al., 2006). Raz e colaboradores (1996) também demonstraram que a injeção intramuscular e intradérmica não variam no perfil da resposta imunológica desencadeada, mesmo a segunda sendo um sítio com maior número de células dendríticas (Raz, Tighe et al., 1996).

Após 30 dias da última imunização foram realizados os ensaios para detecção da resposta induzida por essas vacinas. Primeiramente avaliou-se a resposta imunológica humoral desencadeada por essas construções. A avaliação da produção de anticorpos específicos representa um importante indicador do padrão de resposta induzido pela 
vacinação. Uma vez que anticorpos IgG1 e IgG2a podem ser considerados marcadores dos padrões Th2 e Th1, respectivamente, essa avaliação pode ajudar a definir o fenótipo das células T induzidas na vacinação (Coffman, Seymour et al., 1988). A avaliação dos anticorpos gerados pelas vacinas utilizadas nesse trabalho teve como função apenas a descrita acima, de caracterizar o padrão da resposta imunológica, uma vez que não há dados da presença de Hsps na membrana de $M$. tuberculosis que possam ser neutralizadas, ou mesmo não há estudos com a vacina DNAhsp65 que relacione proteção com anticorpos induzido por essa vacina. Dessa forma, os anticorpos induzidos na imunização são contra uma proteína descrita como intracelular de $M$. tuberculosis e não estão envolvidos na resposta protetora.

As vacinas pVAXgDVac1PA e pVAXgDVac2 foram capazes de induzir a produção de anticorpos anti-Hsp65, anti-Vac1 e anti-Vac2 do subtipo IgG2a enquanto a vacina pVAXhsp65 induz anticorpos dos dois subtipos, IgG1 e IgG2a, mas apenas anticorpos que reconhecem a Hsp65. Isso demonstra um padrão misto de resposta para a vacina pVAXhsp65, já demonstrado pelo nosso grupo (Goncalves, Bonato et al., 2007; Rosada, De La Torre et al., 2008; Souza, Zarate-Blades et al., 2008) e um padrão Th1 induzido pelas vacinas pVAXgDVac1PA e pVAXgDVac2.

Era esperada a indução de anticorpos anti-Vac1 e anti-Vac2 assim como de antiHsp65, nos animais imunizados com pVAXgDVac1PA e pVAXgDVac2, pois as construções vacinais contêm os epitopos da proteína Hsp65 e a única diferença entre as construções Vac1 e Vac2 é a quantidade de epitopos, sendo eles os mesmos nas duas construções. Além disso, essas proteínas são expressas na superfície de células "transfectadas" como demonstrado por Lasaro e colaboladores (2005 e 2008) ficando expostas e facilitando o reconhecimento pelas células B (Carrasco e Batista, 2006).

Já os animais imunizados com pVAXhsp65 não induziram anticorpos anti-Vac1 e anti-Vac2, mas somente anti-Hsp65. Três hipóteses são propostas: $1^{\mathbf{o}}$ ) a proteína Hsp65 
expressa pela vacina pVAXhsp65 deve apresentar uma conformação que não exibe os epitopos utilizados nesse trabalho, dessa forma, anticorpos contra esses epitopos não foram gerados em animais imunizados com essa vacina, $2^{\circ}$ ) foram gerados anticorpos contra epitopos conformacionais que não estão presentes nas proteínas Vac1 e Vac2 desnaturadas no processo de solubilização, ou $3^{\circ}$ ) a proteína Hsp65 apresenta outros epitopos que são imunodominantes em relação aos epitopos presentes nas construções Vac1 e Vac2.

Cada patôgeno apresenta uma grande quantidade de epitopos ao sistema imunológico do hospedeiro, no entanto, a resposta imunológica é focada em apenas alguns desses epitopos o que é conhecido como imunodominância (Frank, 2002). Em relação a imunodominância nos anticorpos, já foi demonstrado por Kumar e colaboradores (1992) que a resposta humoral inicial contra um polipeptídeo, derivado do envelope do vírus da hepatite B (MEP-1), era composta por IgM específica aos vários epitopos presentes nesse peptídeo. No entanto, a IgG, induzida mais tardiamente, era específica a apenas um epitopo do MEP-1. Essas observações suportam a idéia que apenas alguns epitopos são capazes de induzir a expansão de linfócitos B específicos e a troca de isotipo (IgM para IgG).

Diante dessas observações é possível que os epitopos da Hsp65 presentes nas construções Vac1 e Vac2 não sejam imunodominantes e por isso não induzem a produção de anticorpos do subtipo IgG. No entanto, quando os animais são imunizados com essas construções, Vac1 e Vac2 associadas a gD, e não com a proteína Hsp65, a ausência dos outros epitopos imunodominantes e a presença da proteína $\mathrm{gD}$ pode favorecer a mudança na imunodominância.

Um resultado inesperado foi a ausência de anticorpos contra as proteínas recombinantes Hsp65, Vac1 e Vac2 nos animais imunizados com a vacina pVAXgDVac1AA. As proteínas expressas pelos plasmídeos pVAXgDVac1AA, pVAXgDVac1PA e pVAXgDVac2 são expressas na superfície de células "transfectadas" com essas construções 
devido a presença da proteína transmembrânica gD. Dessa forma, acredita-se que a proteína gDVac1AA na superfície da célula assuma uma conformação tal que os epitopos presentes na construção Vac1 não são exibidos. Ao contrário, a proteína gDVac1PA por ser menor devido a retirada da porção central da proteína $\mathrm{gD}$ e a gDVac2 por ter a construção Vac2 maior que a Vac1 devem assumir conformações nas quais os epitopos presentes nas construções Vac1 e Vac2 ficam acessíveis ao reconhecimento das células B. Ou ainda pode ocorrer o mesmo discutido acima que é a presença de anticorpos para epitopos conformacionais não encontrados nas proteínas Vac1 e Vac2. Acredita-se que a ausência de anticorpos específicos as proteínas Hsp65, Vac1 e Vac2 nos animais imunizados com pVAXgDVac1AA não seja devido a imunodominância de outros epitopos presentes na proteína $\mathrm{gD}$, pois se isso ocorresse nesses animais era provável que ocorresse também nos animais imunizados com pVAXgDVac2.

Embora a produção dos anticorpos desencadeados pelas vacinas utilizadas nas imunizações não seja um fator preponderante no controle da resposta imunológica contra a TB, eles são importantes indicadores da resposta imunológica e demonstram a funcionalidade das células B nesse sistema. As células B são importantes células produtoras de anticorpos, mas também funcionam como apresentadoras de antígenos capturando-os através de seus receptores de imunoglobulinas, processando-os e apresentando-os para as células T (Ozaki e Berzofsky, 1987). Além disso, podem capturar ou ser transfectadas com DNA plasmideal (Coelho-Castelo, Santos Junior et al., 2003) funcionando como APC ou como célula produtora de antígeno, isto é, a celula B pode capturar a vacina de DNA, produzir o antígeno intracelularmente e secretá-lo.

A resposta mais importante para patógenos intracelulares como M. tuberculosis é a ativação de células $\mathrm{T} \mathrm{CD}^{+}$e $\mathrm{T} \mathrm{CD}^{+}$. As vacinas de DNA são principalmente conhecidas por desencadearem resposta de células $\mathrm{T} C D 8^{+}$contra os antígenos codificados por elas por serem 
proteínas produzidas no citoplasma das células transfectadas assim como em uma infecção viral ou expressão de proteínas próprias citoplasmáticas (Liu, 2003; Tonheim, Bogwald et al., 2008). Dessa forma, quando a vacina de DNA é capturada por uma APC, essas células ativam os linfócitos T CD8 ${ }^{+}$via MHC-I (Liu, 2003; Tonheim, Bogwald et al., 2008).

As vacinas de DNA também ativam linfócitos T CD4 , pois as células "transfectadas" podem produzir a proteína e secretá-la deixando-a disponível para as células apresentadoras de antígenos que a fagocitam e ativam células T CD4 ${ }^{+}$via moléculas de MHC-II (Liu, 2003; Tonheim, Bogwald et al., 2008). As células $\mathrm{T} \mathrm{CD}^{+}$e $\mathrm{T} \mathrm{CD}^{+}$podem ainda ser ativadas pelo fenômeno do "cross-priming" que ocorre quando células "transfectadas" com o DNA sofrem apoptose e células apresentadoras capturam corpos apoptóticos contendo a proteína codificada pela vacina de DNA e apresentam via MHC de classe I e II (Chattergoon, Shames et al., 2003; Tonheim, Bogwald et al., 2008).

Nesse contexto, a avaliação da resposta imunológica desencadeada pelas imunizações teve como principal objetivo verificar a resposta celular contra os antígenos codificados pelas vacinas de DNA, visto que essa é a resposta requerida para o combate a um patógeno intracelular. A resposta celular foi inicialmente avaliada pela análise da proliferação de linfócitos do baço dos animais imunizados quando estimulados ex vivo. Após 30 dias da última imunização, as células do baço dos animais imunizados com as diferentes construções vacinais foram estimuladas com as proteínas Hsp65, Vac1 e Vac2 e a proliferação analisada pela incorporação de timidina. O ensaio de linfoproliferação é importante, pois indica a presença de linfócitos específicos e de memória a um determinado antígeno por meio da proliferação celular. Como no ensaio foram utilizadas as proteínas Hsp65, Vac1 e Vac2, apenas linfócitos com TCR específicos para peptídeos dessas proteínas seriam capazes de proliferar. 
A ausência de estímulo foi utilizada como controle negativo dos experimentos e o controle positivo foi realizado com o mitógeno concanavalina A que estimula inespecíficamente todos os clones de linfócitos T. Esse estímulo foi capaz de ativar a resposta das células de todos os animais, independente da vacina utilizada para a imunização. Isso ocorre, pois ConA, uma proteína polimérica derivada da planta Canavalia ensiformis, se liga a resíduos de açúcares nas glicoproteínas de superfície das células $\mathrm{T}$, incluindo o TCR (Receptor de Célula T) e o CD3, provocando assim ativação inespecífica (Abbas, 2005).

Com relação aos estímulos específicos, apenas as células dos animais vacinados com pVAXhsp65, pVAXgDVac1PA, pVAXgDVac1AA e pVAXgDVac2 proliferaram frente a proteína Hsp65 indicando a presença de linfócitos T específicos para peptídeos dessa proteína nesses animais. Os animais imunizados com a vacina pVAXhsp65 apresentam expressão da proteína Hsp65 que é processada e apresentada para os linfócitos T, assim células cujo TCR são específicos para peptídeos dessa proteína foram primados. Como o estímulo ex vivo foi realizado com a mesma proteína e, acredita-se que as enzimas lisossomais ou o proteassoma atuam em ligações peptídicas específicas, era esperado que os peptídeos formados pela degradação do estímulo Hsp65 fossem os mesmos formados quando essa proteína foi expressa a partir da vacina de DNA e degradada, dessa forma, os peptídeos gerados são reconhecidos pelas células já primadas desses animais. Já os animais imunizados com as outras três vacinas primam células que apresentam o TCR específico aos peptídeos gerados pelo processamento das proteínas Vac1 e Vac2 expressas pelas vacinas e quando estimulados ex vivo com a proteína Hsp65 inteira proliferam indicando que esses peptídeos são gerados naturalmente após o processamento da proteína Hsp65.

As células dos animais vacinados com pVAXgDVac1PA, pVAXgDVac1AA e pVAXgDVac2 também foram capazes de proliferar quando estimuladas com as proteínas Vac1 e Vac2 que são os estímulos específicos dessas vacinas. No entanto, as células dos 
animais imunizados com a vacina pVAXhsp65 não foram capazes de responder frente a esses dois estímulos. Esse fato aconteceu, provavelmente porque os linfócitos T primados com essa vacinação não são os que apresentam TCR específico aos peptídeos das proteínas Vac1 e Vac2. Novamente a proteína Hsp65 deve apresentar outros epitopos que são imunodominantes em relação aos epitopos presentes nas proteínas Vac1 e Vac2, no entanto, agora para as células T.

Apesar das proteínas Vac1 e Vac2 serem formadas pelos epitopos da proteína Hsp65, esses epitopos não foram descritos como sendo os peptídeos preferencialmente que se ligam as moléculas de MHC ou como sendo os epitopos imunodominantes e sim como sendo reconhecidos pelo TCR dos linfócitos T (Mustafa, Lundin et al., 1999; Charo, Geluk et al., 2001). Dessa forma, o que pode ocorrer nos animais imunizados com a vacina pVAXhsp65 é que esses epitopos sejam gerados, mas preferencialmente outros peptídeos da Hsp65, que são imunominantes, se ligam as moléculas de MHC ativando outros clones de linfócitos T que não os específicos a esses epitopos.

A determinação de epitopos imunodominantes é difícil de ser feita, pois vários fatores estão envolvidos nesse processo. A quantidade e a clivagem do antígeno, o transporte intracelular e a ligação dos peptídeos formados as moléculas de MHC, bem como a especificidade dos receptores de células T são alguns dos eventos envolvidos com a seleção de epitopos imunodominantes (Frank, 2002). Análises in silico de predição de epitopos tentam levar em consideração o processamento das proteínas, a ligação dos peptídeos gerados as moléculas de MHC (levando em consideração moléculas transportadoras como a TAP) e a interação com o TCR, no entanto, nem sempre os peptídeos selecionados dessa forma, que na maioria das vezes são os imunodominantes, são os que geram melhor resposta. Muitas vezes epitopos que apresentam menor afinidade ao MHC e não são selecionados em sistemas de 
predição são os que levam a uma resposta melhor contra um determinado patôgeno (Magdalini Moutafsi, 2006).

Apesar da presença de epitopos imunodominantes na proteína Hsp65 que não são aqueles presentes nas construções Vac1 e Vac2, quando os animais são imunizados com as vacinas pVAXgDVac1PA, pVAXgDVac1AA e pVAXgDVac2 possivelmente há uma quebra na imunodominância, pois não existe outros epitopos da proteína Hsp65 que serão alvos da resposta imunológica. É descrito que clones de linfócitos $\mathrm{T}$ citotóxicos (CTLs) imunodominantes suprimem a ação de clones subdominantes, e essa supressão não está relacionada a competição entre epitopos dominantes e subdominantes pela ligação com as moléculas de MHC. Os clones dominantes podem de forma direta, pela produção de citocinas supressoras, ou indireta, pela competição por recursos, como as APCs, suprimir a ação dos subdominantes (Yewdell e Bennink, 1999; Frank, 2002). Dessa forma, na ausência desses clones dominantes, como no caso da imunização com as vacinas pVAXgDVac1PA, pVAXgDVac1AA e pVAXgDVac2 pode ocorrer ação dos clones subdominantes havendo uma reversão na imunodominância como já foi descrita por outros pesquisadores (Cole, Hogg et al., 1997; Frank, 2002).

Dessa forma, apesar dos epitopos presentes nas construções Vac1 e Vac2 não serem os epitopos imunodominantes da proteína Hsp65, a imunização com as vacinas pVAXgDVac1AA, pVAXgDVac1PA e pVAXgDVac2 reverte o quadro da imunodominância, induzindo o "prime" de células T específicas a esses epitopos que respondem frente ao estímulo Hsp65 indicando que esses epitopos são processados naturalmente e monstrando a viabilidade dessas vacinas.

O próximo passo na avaliação da resposta celular foi verificar o fenótipo celular das células que proliferam frente aos estímulos específicos. A avaliação foi realizada inicialmente em relação aos marcadores CD4 e CD8. A porcentagem de células $\mathrm{T}$ CD4 ${ }^{+}$foi maior nos 
animais vacinados com as três construções vacinais pVAXgDVac1PA, pVAXgDVac1AA e pVAXgDVac2 quando estimulados com as proteínas específicas Vac1 e Vac2. Os animais vacinados com pVAXgDVac1PA e pVAXgDVac1AA também apresentaram maior porcentagem de células $\mathrm{T} \mathrm{CD}^{+}$quando estimulados com Hsp65 e comparados ao grupo salina. Já a porcentagem de células $\mathrm{T} \mathrm{CD}^{+}$foi maior nos animais imunizados com as quatro vacinas, pVAXhsp65, pVAXgDVac1PA, pVAXgDVac1AA e pVAXgDVac2 quando estimulados com as proteínas específicas Hsp65, Vac1 e Vac2 e comparados aos grupos salina e vetor.

A presença de linfócitos $\mathrm{T}^{\mathrm{CD}} 8^{+}$nos animais imunizados com pVAXhsp65 e estimulados com Vac1 e Vac2 apesar de não corroborar com os resultados da linfoproliferação, confirma que os epitopos das proteínas Vac1 e Vac2 são gerados naturalmente pelo processamento da Hsp65 e que linfócitos T $\mathrm{CD} 8^{+}$específicos a eles podem ser primados na imunização com a vacina pVAXhsp65. Além disso, as vacinas pVAXgDVac1PA, pVAXgDVac1AA e pVAXgDVac2 foram capazes de gerar maior quantidade de linfócitos $\mathrm{T} \mathrm{CD}^{+}$quando comparadas a vacina pVAXhsp65 (estímulo Vac1 e Vac2). Ao contrário, todas as vacinas, inclusive a pVAXhsp65, foram semelhantes na porcentagem de linfócitos $\mathrm{T} \mathrm{CD}^{+}$.

A resposta dos linfócitos T após as imunizações também foi avaliada e caracterizada com relação a produção de citocinas. As citocinas caracterizam o padrão de resposta gerado em uma infecção ou imunização, mas além de caracterizar, modulam a resposta imunológica, ativando ou inibindo a resposta celular. A resposta imunológica é diferente para os distintos patógenos existentes, parasitas que não infectam células, sobrevivem no hospedeiro extracelularmente e requerem, principalmente, linfócitos do padrão Th2 que produzem IL-4 e IL-5 responsáveis pela ativação de eosinófilos envolvidos na eliminação de patógenos extracelulares (Berger, 2000; Abbas, 2005). Já patógenos intracelulares como o bacilo $M$. 
tuberculosis são eliminados principalmente por uma resposta do padrão Th1 com produção de IFN- $\gamma$ pelos linfócitos que ativam macrófagos a provocar a lise do patógeno por meio de suas atividades microbicidas (Berger, 2000; Abbas, 2005).

Os diferentes padrões de respostas são desencadeados de acordo com as semelhanças e diferenças entre os patógenos. O padrão Th1 é ativado pela secreção de IL-12 pelas células apresentadoras de antígenos após a fagocitose de um microorganismo, ao contrário o padrão Th2 é desencadeado pela produção de IL-4 no início da infecção (Swain, Weinberg et al., 1990; Macatonia, Hosken et al., 1995; Abbas, 2005). Distintas respostas precisam ser desencadeadas de acordo com cada microorganismo a que o hospedeiro foi exposto, no entanto, essas respostas precisam ser controladas quando o patógeno é eliminado ou mesmo para a resposta imunológica não desencadear injúria no tecido do hospedeiro. Dessa forma, o sistema imunológico também apresenta mecanismos de regulação compostos por células e citocinas como a células $\mathrm{T}$ reguladoras e as citocinas IL-10 e TGF- $\beta$ (Abbas, 2005). As células $\mathrm{T}$ reguladoras podem atuar interagindo diretamente com determinadas células ou secretar IL-10 e TGF- $\beta$ que estão envolvidos na inibição da ativação de macrófagos e inibição de células T e B, respectivamente (Abbas, 2005).

Dessa forma, nesse trabalho foram avaliadas as citocinas IFN- $\gamma$, IL-12, IL-2, IL-5 e IL-10 para caracterizar o padrão de resposta gerado pelas vacinas utilizadas. As células do baço dos animais imunizados com as diferentes construções vacinais foram estimuladas e a quantificação das citocinas realizada no sobrenadante da cultura. A ausência de estímulo foi utilizada como controle negativo dos experimentos e como controle positivo foi utilizado ConA. As células dos animais vacinados com pVAXhsp65, pVAXgDVac1PA, pVAXgDVac1AA e pVAXgDVac2 foram estimuladas a produzir IFN- $\gamma$ quando estimuladas com a proteína Hsp65 indicando a presença de linfócitos T específicos para peptídeos dessa proteína nesses animais. Os animais vacinados com pVAXgDVac1PA, pVAXgDVac1AA e 
pVAXgDVac2 também foram capazes de responder produzindo IFN- $\gamma$ quando suas células foram estimuladas com as proteínas Vac1 e Vac2 que são os estímulos específicos dessas vacinas. No entanto, as células dos animais imunizados com a vacina pVAXhsp65 não foram capazes de responder frente a esses dois estímulos. As vacinas pVAXgDVac1PA, pVAXgDVac1AA e pVAXgDVac2 foram ainda capazes de induzir maior produção de IFN- $\gamma$ quando comparadas a vacina pVAXhsp65.

Esses resultados foram importantes, pois corroboram com os dados da linfoproliferação e, além disso, mostram a função efetora dos linfócitos estimulados e indicam o padrão Th1 desenvolvido pelos animais imunizados com as construções vacinais. Além disso, juntamente com os dados de fenótipo celular indicam que o IFN- $\gamma$ pode ser produzido pelas células $\mathrm{T} \mathrm{CD}^{+}$e $\mathrm{T} \mathrm{CD}^{+}$(grupos pVAXhsp65 e pVAXgDVac2 estimulados com Hsp65). Dessa forma, esses resultados correlacionam a proliferação, o aumento na porcentagem de células $\mathrm{T} \mathrm{CD}^{+}$e $\mathrm{T} \mathrm{CD}^{+}$e a produção de INF- $\gamma$ e mostram que as vacinas pVAXgDVac1PA, pVAXgDVac1AA e pVAXgDVac2 foram mais eficientes que a vacina pVAXhsp65.

Como já foi demonstrado pelo nosso grupo que a proteção contra TB induzida pela vacina DNAhsp65 é atribuída principalmente a produção de IFN- $\gamma$ e a presença de células T $\mathrm{CD}^{+}$específicas (Lowrie, Silva et al., 1997; Bonato, Lima et al., 1998), os resultados obtidos com as vacinas pVAXgDVac1PA, pVAXgDVac1AA e pVAXgDVac2 sugerem que essas construções podem ser eficazes na profilaxia da TB.

Outra citocina avaliada foi a IL-2 que é um fator de crescimento para linfócitos T estimulados por antígenos e é responsável pela expansão clonal após o reconhecimento antigênico (Abbas, 2005). Os resultados corroboram com os resultados de linfoproliferação e aumento na porcentagem de células $\mathrm{T} \mathrm{CD}^{+}$e $\mathrm{T}$ CD8 ${ }^{+}$. Em relação a citocina IL-12 todos os grupos apresentaram pequena produção sem diferenças entre eles (dados não mostrados), o 
que era esperado visto que essa é uma citocina produzida por células apresentadoras de antígenos as quais no ensaio ex vivo são responsáveis pela apresentação do antígeno e estimulação dos linfócitos T. As citocinas IL-5 e IL-10 não foram detectadas nos animais dos diferentes grupos, exceto nas células estimuladas com ConA que estimula a produção de ambas as citocinas (dados não mostrados). Esses dados confirmam a presença do padrão Th1 sem a interferência de citocinas do padrão Th2 ou regulatórias que possam inibir a imunidade mediada por células.

Como alguns pesquisadores acreditam que o padrão Th1 falha no controle da TB devido a presença de células reguladoras ou do padrão Th2 (Guyot-Revol, Innes et al., 2006; Kursar, Koch et al., 2007; Seah e Rook, 2001; Rook, 2007), a ausência desse perfil nos animais imunizados com as vacinas pVAXgDVac1PA, pVAXgDVac1AA e pVAXgDVac2 pode novamente sugerir a eficácia dessas construções na proteção contra a TB. No entanto, a presença de mecanismos reguladores da resposta imunológica são importantes na TB uma vez que os sintomas dessa doença ocorrem devido a resposta imunológica desencadeada no tecido alvo.

A IL-10 e TGF- $\beta$, como já foi mencionado, são importantes citocinas envolvidas na inibição da ativação de macrófagos e de células T e B, respectivamente (Abbas, 2005). Dessa forma, elas são moléculas importantes para regular as ações inflamatórias no tecido do hospedeiro. A IL-10 é importante, no entanto, demonstra papéis controversos na imunopatologia da TB. Um trabalho do nosso grupo demonstra aumento de IFN- $\gamma$, diminuição de IL-10 com conseqüente proteção contra a TB e preservação do parênquima pulmonar em camundongos vacinados com DNAhsp65 complexada a lipossoma, entretanto, outro trabalho mostra aumentos dos níveis de IFN- $\gamma$ e IL-10 juntamente com proteção e preservação do parênquima pulmonar em camundongos vacinados e desafiados com $M$. tuberculosis (Goncalves, Bonato et al., 2007; Rosada, De La Torre et al., 2008). Dessa forma, 
a citocina IL-10 e outros mecanismos de regulação são importantes na preservação da integridade pulmonar e precisarão ser avaliados em experimentos de profilaxia contra a TB com as vacinas pVAXgDVac1PA, pVAXgDVac1AA e pVAXgDVac2.

Outra avaliação importante após a administração de uma vacina é a avaliação da presença de células de memória uma vez que em muitos casos o aumento no número dessas células está relacionado com aumento da proteção contra determinada infecção (Badovinac e Harty, 2006). Dessa forma, foi avaliado o perfil das células com relação ao fenótipo de memória. Vários marcadores de superfície são utilizados para caracterizar as células de memória, CD27, CD44, CD62L, CD127 e CCR7 entre outros. Estudos sugerem que a expressão de moléculas de "homing" como o CD62L e o CCR7, que implicam na retenção das células nos órgãos linfóides secundários, podem ser usados para diferenciar os subtipos de memória, $\mathrm{CD} 62 \mathrm{~L}^{\text {low }} \mathrm{CCR} 7^{\text {low }}$ para memória efetora, e $\mathrm{CD} 62 \mathrm{~L}^{\text {high }} \mathrm{CCCR} 7^{\text {high }}$ para memória central (Sallusto, Geginat et al., 2004). Entretanto, trabalhos mais recentes sugerem que o fenótipo celular de superfície pode ser falho em caracterizar os atributos funcionais das células de memória (Badovinac e Harty, 2006). Dessa forma, muitas vezes é importante identificar as citocinas produzidas por essas populações celulares, além de caracterizar seus marcadores de superfície.

A maioria das células $\mathrm{T} \mathrm{CD}^{+}$após uma infecção aguda apresentam, além de marcadores de superfície para células efetoras produção alta de IFN- $\gamma$, média de TNF- $\alpha$ e nenhuma produção de IL-2. Ao contrário, após a eliminação do antígeno, além do fenótipo de memória central na superfície, essas células apresentam alta produção de IFN- $\gamma$ e TNF- $\alpha$ e média de IL-2 (Sallusto, Geginat et al., 2004; Badovinac e Harty, 2006) mostrando a importância em se analisar o estado funcional dos subtipos de memória, pois são essas características que determinarão a proteção. 
Apesar da importância em se determinar a expressão de citocinas pelas células de memória e a comum utilização dos marcadores de superfície CD62L e CCR7 para caracterizar essas células os marcadores utilizados nesse trabalho foram o CD62L e o CD44, que também é um importante marcador na definição de células de memória. O receptor CD44 promove adesão nas células endoteliais e matriz extracelular e os linfócitos efetores apresentam alta expressão dessa molécula (Lesley, Hyman et al., 1993; Abbas, 2005). O marcador CD62L é uma L-selectina com função de reter os linfócitos naive e de memória nos órgãos linfóides periféricos (Rainer, 2002; Abbas, 2005). A avaliação desses fenótipos é importante após a vacinação, pois se espera que as imunizações promovam o desenvolvimento de células de memória capazes de responder efetivamente a um subseqüente reestimulo (infecção).

Os resultados obtidos com a análise do fenótipo das células $\mathrm{T} \mathrm{CD}^{+}$e $\mathrm{T} \mathrm{CD}^{+} \mathrm{em}$ relação a porcentagem de células de memória $\left(\mathrm{CD} 44{ }^{\text {hi }} \mathrm{CD} 62 \mathrm{~L}^{+}\right)$demonstraram que não houve diferenças entre os distintos grupos experimentais estimulados com Hsp65 (dados não mostrados), Vac1 e Vac2.

Como a vacinação gera células de memória e uma forma alternativa de definir essa população é sua expansão vigorosa após o reestimulo (Badovinac e Harty, 2006), esperávamos verificar um aumento na população de células de memória efetora $\left(\mathrm{CD} 44^{\mathrm{hi}} \mathrm{CD} 62 \mathrm{~L}^{\mathrm{lo}}\right)$ nos grupos imunizados com as construções vacinais após o estímulo ex vivo com as proteínas específicas. Os resultados demonstram que houve proliferação celular após o estímulo e ocorreu um aumento nas populações de células $\mathrm{T} \mathrm{CD} 4^{+}$e $\mathrm{T} \mathrm{CD} 8^{+}$, no entanto, esse aumento não pôde ser correlacionado ao fenótipo de memória, pois a análise não foi bem sucedida. Uma hipótese para justificar a falta de dados conclusivos é a metodologia utilizada uma vez que a população de células de memória é pequena e difícil de ser analisada dependendo da quantidade de eventos avaliados por citometria de fluxo. Além disso, essa população é difícil de caracterizar devido aos diversos marcadores que as identificam. Dessa 
forma, se tivessemos avaliados mais eventos, usado mais marcadores de memória ou a tecnologia de tetrâmeros de MHC-antígeno que isola células específicas ao antígeno poderíamos caracterizar melhor essa população tendo um resultado diferente.

Além dessa hipótese, alguns trabalhos mostram que as células $\mathrm{T} \mathrm{CD}^{+}$de memória secundária (geradas após mais de uma imunização) não expressam rapidamente o marcador CD62L, apesar de sustentada produção de granzima B e eficácia na proteção. Além disso, apesar das células $\mathrm{T} \mathrm{CD}^{+}$de memória apresentarem robusta capacidade proliferativa, as estimulações sucessíveis podem provocar um declínio na proliferação indicando que essas células são capazes de sofrer sucessivas, mas finitas divisões (Masopust, Ha et al., 2006).

No entanto, apesar dos dados não conclusivos da população de células de memória, a proliferação celular e a resposta funcional das células (produção de IFN- $\gamma$ ) indicam a eficácia das vacinas construídas em gerar resposta celular. Além disso, pudemos concluir que os peptídeos das proteínas Vac1 e Vac2 são gerados naturalmente no processamento da proteína Hsp65 e de forma correta mesmo estando fusionadas a glicoproteína D e mesmo na ausência de espaçadores entre os epitopos que facilitam o processamento (Velders, Weijzen et al., 2001; Wang, Sun et al., 2004). A retirada de uma porção central da gD (vacina pVAXgDVac1PA) não prejudicou sua atividade adjuvante. A eliminação de uma porção central da gD pode até melhorar a resposta imunológica caso a conformação gerada exponha ainda mais o sítio de interação ao seu receptor. Lasaro e colaboradores (2008) demonstraram que a fusão de um peptídeo no interior da gD no sítio da enzima ApaI alterou a conformação dessa proteína (forma solúvel) afastando a porção C-terminal da porção de interação com o receptor HVEM o que não prejudicou sua interação.

A presença da gD pode ser um fator preponderante na melhor resposta das células dos animais imunizados com as vacinas construídas nesse trabalho em comparação a vacina pVAXhsp65. Lasaro e colaboradores (2008) mostrou claramente que vacinas de DNA 
construídas com a gD induziram maiores títulos de anticorpos e porcentagem de células $\mathrm{T}$ $\mathrm{CD} 8^{+}$produtoras de IFN- $\gamma$ quando comparadas a vacinas que não apresentavam o gene dessa proteína. As vacinas pVAXgDVac1PA, pVAXgDVac1AA e pVAXgDVac2 expressam os epitopos em fusão com a proteína gD que interage com seu receptor HVEM presente em diferentes células do sistema imunológico (Montgomery, Warner et al., 1996). Essa interação pode levar a uma melhor ativação da imunidade inata com produção de IL-12 que induz um padrão Th1 de resposta (Medici, Sciortino et al., 2003; Pollara, Jones et al., 2004) e melhora a ativação dos linfócitos $\mathrm{T}$ epitopo-específicos. Além disso, a gD pode também interagir com seu receptor presente nos linfócitos $\mathrm{T}$, no entanto, não há trabalhos que descrevem essa interação.

Os resultados demonstram, portanto, o grande potencial das três vacinas de DNA construídas em gerar uma resposta imunológica do padrão Th1, importante no combate a tuberculose. Os resultados apresentados nesse trabalho sugerem que as vacinas pVAXgDVac1PA, pVAXgDVac1AA e pVAXgDVac2 podem ser eficazes na profilaxia da TB e apresentam uma nova estratégia em relação a vacina DNAhsp65 devido a presença da proteína gD. 


\subsection{CONCLUSÕES}

»As vacinas pVAXgDVac1PA, pVAXgDVac1AA e pVAXgDVac2, bem como o vetor pVAXgD foram corretamente construídos e caracterizados como observado pela reação em cadeia da polimerase, digestão com endonucleases, seqüenciamento, avaliação dos transcritos e da proteína;

» As construções vacinais induziram o padrão Th1 de resposta, com produção de anticorpos do subtipo IgG2a, indução da proliferação celular, produção de IFN- $\gamma$ e aumento na porcentagem de células T CD4 ${ }^{+}$e $\mathrm{T} \mathrm{CD} 8^{+}$;

»As vacinas induziram melhor resposta do que a vacina pVAXhsp65. 


\subsection{REFERÊNCIAS BIBLIOGRÁFICAS}

Aaron, L., D. Saadoun, et al. Tuberculosis in HIV-infected patients: a comprehensive review. Clin Microbiol Infect, v.10, n.5, May, p.388-98. 2004.

Abbas, A. K. A. L., A.H. Imunologia Celular e Molecular. Rio de Janeiro, R.J.: Elsevier. 2005

Aderem, A. e R. J. Ulevitch. Toll-like receptors in the induction of the innate immune response. Nature, v.406, n.6797, Aug 17, p.782-7. 2000.

Afek, A., J. George, et al. Immunization of low-density lipoprotein receptor deficient (LDLRD) mice with heat shock protein 65 (HSP-65) promotes early atherosclerosis. J Autoimmun, v.14, n.2, Mar, p.115-21. 2000.

Ana Cláudia Pelizon, D. R. M., Sofia Fg Zorzella, Ana Paula, J. C. L. F Trombone, Robson F Carvalho, Izaíra T Brandão, et al. Genetic vaccine for tuberculosis (pVAXhsp65) primes neonate mice for a strong immune response at the adult stage. Genetic Vaccines and Therapy, v.5, n.12, p.1-9. 2007.

Armengol, G., L. M. Ruiz, et al. The injection of plasmid DNA in mouse muscle results in lifelong persistence of DNA, gene expression, and humoral response. Mol Biotechnol, v.27, n.2, Jun, p.109-18. 2004.

Armstrong, J. A. e P. D. Hart. Phagosome-lysosome interactions in cultured macrophages infected with virulent tubercle bacilli. Reversal of the usual nonfusion pattern and observations on bacterial survival. J Exp Med, v.142, n.1, Jul 1, p.1-16. 1975.

Badovinac, V. P. e J. T. Harty. Programming, demarcating, and manipulating CD8+ T-cell memory. Immunol Rev, v.211, Jun, p.67-80. 2006.

Bafica, A., C. A. Scanga, et al. TLR9 regulates Th1 responses and cooperates with TLR2 in mediating optimal resistance to Mycobacterium tuberculosis. J Exp Med, v.202, n.12, Dec 19, p.1715-24. 2005.

Balcewicz-Sablinska, M. K., J. Keane, et al. Pathogenic Mycobacterium tuberculosis evades apoptosis of host macrophages by release of TNF-R2, resulting in inactivation of TNF-alpha. J Immunol, v.161, n.5, Sep 1, p.2636-41. 1998.

Baneyx, F. e M. Mujacic. Recombinant protein folding and misfolding in Escherichia coli. Nat Biotechnol, v.22, n.11, Nov, p.1399-408. 2004.

Beckman, E. M., S. A. Porcelli, et al. Recognition of a lipid antigen by CD1-restricted alpha beta+ T cells. Nature, v.372, n.6507, Dec 15, p.691-4. 1994.

Belakova, J., M. Horynova, et al. DNA vaccines: are they still just a powerful tool for the future? Arch Immunol Ther Exp (Warsz), v.55, n.6, Nov-Dec, p.387-98. 2007.

Berger, A. Th1 and Th2 responses: what are they? Bmj, v.321, n.7258, Aug 12, p.424. 2000. 
Berrington, W. R. e T. R. Hawn. Mycobacterium tuberculosis, macrophages, and the innate immune response: does common variation matter? Immunol Rev, v.219, Oct, p.167-86. 2007.

Berthet, F. X., P. B. Rasmussen, et al. A Mycobacterium tuberculosis operon encoding ESAT-6 and a novel low-molecular-mass culture filtrate protein (CFP-10). Microbiology, v.144 ( Pt 11), Nov, p.3195-203. 1998.

Bhatt, K. e P. Salgame. Host innate immune response to Mycobacterium tuberculosis. J Clin Immunol, v.27, n.4, Jul, p.347-62. 2007.

Bivas-Benita, M., K. E. Van Meijgaarden, et al. Pulmonary delivery of chitosan-DNA nanoparticles enhances the immunogenicity of a DNA vaccine encoding HLA-A*0201restricted T-cell epitopes of Mycobacterium tuberculosis. Vaccine, v.22, n.13-14, Apr 16, p.1609-15. 2004.

Bodmer, J. L., P. Schneider, et al. The molecular architecture of the TNF superfamily. Trends Biochem Sci, v.27, n.1, Jan, p.19-26. 2002.

Bodnar, K. A., N. V. Serbina, et al. Fate of Mycobacterium tuberculosis within murine dendritic cells. Infect Immun, v.69, n.2, Feb, p.800-9. 2001.

Bonato, V. L., E. D. Goncalves, et al. Immune regulatory effect of pHSP65 DNA therapy in pulmonary tuberculosis: activation of CD8+ cells, interferon-gamma recovery and reduction of lung injury. Immunology, v.113, n.1, Sep, p.130-8. 2004.

Bonato, V. L., V. M. Lima, et al. Identification and characterization of protective T cells in hsp65 DNA-vaccinated and Mycobacterium tuberculosis-infected mice. Infect Immun, v.66, n.1, Jan, p.169-75. 1998.

Bradford, M. M. A rapid and sensitive method for the quantitation of microgram quantities of protein utilizing the principle of protein-dye binding. Anal Biochem, v.72, May 7, p.248-54. 1976.

Brandt, L., Y. A. Skeiky, et al. The protective effect of the Mycobacterium bovis BCG vaccine is increased by coadministration with the Mycobacterium tuberculosis 72-kilodalton fusion polyprotein $M$. tuberculosis $72 \mathrm{~F}$ in M. tuberculosis-infected guinea pigs. Infect Immun, v.72, n.11, Nov, p.6622-32. 2004.

Brightbill, H. D., D. H. Libraty, et al. Host defense mechanisms triggered by microbial lipoproteins through toll-like receptors. Science, v.285, n.5428, Jul 30, p.732-6. 1999.

Brimnes, N. BCG vaccination and WHO's global strategy for tuberculosis control 1948-1983. Soc Sci Med, v.67, n.5, Sep, p.863-73. 2008.

Brown, R. M., O. Cruz, et al. Lipoarabinomannan-reactive human secretory immunoglobulin A responses induced by mucosal bacille Calmette-Guerin vaccination. J Infect Dis, v.187, n.3, Feb 1, p.513-7. 2003.

Buettner, M., C. Meinken, et al. Inverse correlation of maturity and antibacterial activity in human dendritic cells. J Immunol, v.174, n.7, Apr 1, p.4203-9. 2005. 
Calmette, A., and Plotz, H. Protective inoculation against tuberculosis with BCG. Am. Rev. Tuberc, v.19, p.567-572. 1929.

Carfi, A., S. H. Willis, et al. Herpes simplex virus glycoprotein D bound to the human receptor HveA. Mol Cell, v.8, n.1, Jul, p.169-79. 2001.

Carrasco, Y. R. e F. D. Batista. B cell recognition of membrane-bound antigen: an exquisite way of sensing ligands. Curr Opin Immunol, v.18, n.3, Jun, p.286-91. 2006.

Caruso, A. M., N. Serbina, et al. Mice deficient in CD4 T cells have only transiently diminished levels of IFN-gamma, yet succumb to tuberculosis. J Immunol, v.162, n.9, May 1, p.5407-16. 1999.

Casares, S., K. Inaba, et al. Antigen presentation by dendritic cells after immunization with DNA encoding a major histocompatibility complex class II-restricted viral epitope. J Exp Med, v.186, n.9, Nov 3, p.1481-6. 1997.

Castro, A. G., R. A. Silva, et al. Endogenously produced IL-12 is required for the induction of protective $\mathrm{T}$ cells during Mycobacterium avium infections in mice. $\mathrm{J}$ Immunol, v.155, n.4, Aug 15, p.2013-9. 1995.

Chan, J., Y. Xing, et al. Killing of virulent Mycobacterium tuberculosis by reactive nitrogen intermediates produced by activated murine macrophages. J Exp Med, v.175, n.4, Apr 1, p.1111-22. 1992.

Charo, J., A. Geluk, et al. The identification of a common pathogen-specific HLA class I $A^{*} 0201-$ restricted cytotoxic $\mathrm{T}$ cell epitope encoded within the heat shock protein 65 . Eur J Immunol, v.31, n.12, Dec, p.3602-11. 2001.

Chattergoon, M. A., T. M. Robinson, et al. Specific immune induction following DNA-based immunization through in vivo transfection and activation of macrophages/antigen-presenting cells. J Immunol, v.160, n.12, Jun 15, p.5707-18. 1998.

Chattergoon, M. A., J. P. Shames, et al. Engineering cross-presentation in vivo. Expert Opin Biol Ther, v.3, n.6, Sep, p.887-94. 2003.

Cheung, T. C., I. R. Humphreys, et al. Evolutionarily divergent herpesviruses modulate T cell activation by targeting the herpesvirus entry mediator cosignaling pathway. Proc Natl Acad

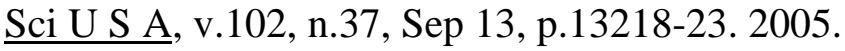

Coelho-Castelo, A. A., R. R. Santos Junior, et al. B-lymphocytes in bone marrow or lymph nodes can take up plasmid DNA after intramuscular delivery. Hum Gene Ther, v.14, n.13, Sep 1, p.1279-85. 2003.

Coelho-Castelo, A. A., A. P. Trombone, et al. Tissue distribution of a plasmid DNA encoding Hsp65 gene is dependent on the dose administered through intramuscular delivery. Genet Vaccines Ther, v.4, p.1. 2006.

Coffman, R. L., B. W. Seymour, et al. The role of helper T cell products in mouse B cell differentiation and isotype regulation. Immunol Rev, v.102, Feb, p.5-28. 1988. 
Cohen, G. H., W. C. Wilcox, et al. Expression of herpes simplex virus type 1 glycoprotein D deletion mutants in mammalian cells. J Virol, v.62, n.6, Jun, p.1932-40. 1988.

Colditz, G. A., T. F. Brewer, et al. Efficacy of BCG vaccine in the prevention of tuberculosis. Meta-analysis of the published literature. Jama, v.271, n.9, Mar 2, p.698-702. 1994.

Cole, S. T., R. Brosch, et al. Deciphering the biology of Mycobacterium tuberculosis from the complete genome sequence. Nature, v.393, n.6685, Jun 11, p.537-44. 1998.

Cole, G. A., T. L. Hogg, et al. Efficient priming of CD8+ memory T cells specific for a subdominant epitope following Sendai virus infection. J Immunol, v.158, n.9, May 1, p.43019. 1997.

Connolly, S. A., D. J. Landsburg, et al. Structure-based mutagenesis of herpes simplex virus glycoprotein $\mathrm{D}$ defines three critical regions at the $\mathrm{gD}$-HveA/HVEM binding interface. $\underline{\mathrm{J}}$ Virol, v.77, n.14, Jul, p.8127-40. 2003.

Cooper, A. M., J. Magram, et al. Interleukin 12 (IL-12) is crucial to the development of protective immunity in mice intravenously infected with mycobacterium tuberculosis. J Exp Med, v.186, n.1, Jul 7, p.39-45. 1997.

Danieli, M. G., D. Markovits, et al. Juvenile rheumatoid arthritis patients manifest immune reactivity to the mycobacterial $65-\mathrm{kDa}$ heat shock protein, to its $180-188$ peptide, and to a partially homologous peptide of the proteoglycan link protein. Clin Immunol Immunopathol, v.64, n.2, Aug, p.121-8. 1992.

Dannenberg, A. M., Jr. Immunopathogenesis of pulmonary tuberculosis. Hosp Pract (Off Ed), v.28, n.1, Jan 15, p.51-8. 1993.

De Paula, L., C. L. Silva, et al. Comparison of different delivery systems of DNA vaccination for the induction of protection against tuberculosis in mice and guinea pigs. Genet Vaccines Ther, v.5, p.2. 2007.

Elias, D., T. Reshef, et al. Vaccination against autoimmune mouse diabetes with a T-cell epitope of the human $65-\mathrm{kDa}$ heat shock protein. Proc Natl Acad Sci U S A, v.88, n.8, Apr 15, p.3088-91. 1991.

Ernst, J. D. Macrophage receptors for Mycobacterium tuberculosis. Infect Immun, v.66, n.4, Apr, p.1277-81. 1998.

Espinal, M. A. The global situation of MDR-TB. Tuberculosis (Edinb), v.83, n.1-3, p.44-51. 2003.

Feige, U. e W. Van Eden. Infection, autoimmunity and autoimmune disease. Exs, v.77, p.35973. 1996.

Feng, C. G. e W. J. Britton. CD4+ and CD8+ T cells mediate adoptive immunity to aerosol infection of Mycobacterium bovis bacillus Calmette-Guerin. J Infect Dis, v.181, n.5, May, p.1846-9. 2000. 
Feng, C. G., M. Kaviratne, et al. NK cell-derived IFN-gamma differentially regulates innate resistance and neutrophil response in $\mathrm{T}$ cell-deficient hosts infected with Mycobacterium tuberculosis. J Immunol, v.177, n.10, Nov 15, p.7086-93. 2006.

Ferrero, E., P. Biswas, et al. Macrophages exposed to Mycobacterium tuberculosis release chemokines able to recruit selected leucocyte subpopulations: focus on gammadelta cells. Immunology, v.108, n.3, Mar, p.365-74. 2003.

Fine, P. E. Variation in protection by BCG: implications of and for heterologous immunity. Lancet, v.346, n.8986, Nov 18, p.1339-45. 1995.

BCG: the challenge continues. Scand J Infect Dis, v.33, n.4, p.243-5. 2001.

Flynn, J. L. Immunology of tuberculosis and implications in vaccine development. Tuberculosis (Edinb), v.84, n.1-2, p.93-101. 2004.

Flynn, J. L. e J. Chan. Immunology of tuberculosis. Annu Rev Immunol, v.19, p.93-129. 2001. 102. 2005.

What's good for the host is good for the bug. Trends Microbiol, v.13, n.3, Mar, p.98-

Flynn, J. L., M. M. Goldstein, et al. Tumor necrosis factor-alpha is required in the protective immune response against Mycobacterium tuberculosis in mice. Immunity, v.2, n.6, Jun, p.561-72. 1995.

Frank, S. A. Immunology and Evolution of Infectious Disease. United Kingdom: Princeton University Press. 2002. 359 p.

Gansert, J. L., V. Kiessler, et al. Human NKT cells express granulysin and exhibit antimycobacterial activity. J Immunol, v.170, n.6, Mar 15, p.3154-61. 2003.

Gardam, M. A., E. C. Keystone, et al. Anti-tumour necrosis factor agents and tuberculosis risk: mechanisms of action and clinical management. Lancet Infect Dis, v.3, n.3, Mar, p.14855. 2003.

Gavrieli, M., N. Watanabe, et al. Characterization of phosphotyrosine binding motifs in the cytoplasmic domain of $\mathrm{B}$ and $\mathrm{T}$ lymphocyte attenuator required for association with protein tyrosine phosphatases SHP-1 and SHP-2. Biochem Biophys Res Commun, v.312, n.4, Dec 26, p.1236-43. 2003.

Gerosa, F., C. Nisii, et al. CD4(+) T cell clones producing both interferon-gamma and interleukin-10 predominate in bronchoalveolar lavages of active pulmonary tuberculosis

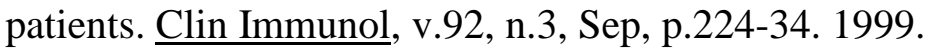

Goncalves, E. D., V. L. Bonato, et al. Improve protective efficacy of a TB DNA-HSP65 vaccine by BCG priming. Genet Vaccines Ther, v.5, p.7. 2007. 
Gonzalez-Juarrero, M., O. C. Turner, et al. Temporal and spatial arrangement of lymphocytes within lung granulomas induced by aerosol infection with Mycobacterium tuberculosis. Infect Immun, v.69, n.3, Mar, p.1722-8. 2001.

Gonzalez, L. C., K. M. Loyet, et al. A coreceptor interaction between the CD28 and TNF receptor family members $\mathrm{B}$ and $\mathrm{T}$ lymphocyte attenuator and herpesvirus entry mediator. Proc Natl Acad Sci U S A, v.102, n.4, Jan 25, p.1116-21. 2005.

Goonetilleke, N. P., H. Mcshane, et al. Enhanced immunogenicity and protective efficacy against Mycobacterium tuberculosis of bacille Calmette-Guerin vaccine using mucosal administration and boosting with a recombinant modified vaccinia virus Ankara. J Immunol, v.171, n.3, Aug 1, p.1602-9. 2003.

Griffiths, A. J. F., Gelbart, W.M., Miller, J.H., Lewonin, R.C. . Capítulo 7: The Molecular Basis of Mutation: W. H. Freeman and Company. 1999 (Modern Genetic Analysis)

Grotzke, J. E. e D. M. Lewinsohn. Role of CD8+ T lymphocytes in control of Mycobacterium tuberculosis infection. Microbes Infect, v.7, n.4, Apr, p.776-88. 2005.

Gurunathan, S., D. M. Klinman, et al. DNA vaccines: immunology, application, and optimization*. Annu Rev Immunol, v.18, p.927-74. 2000.

Guyot-Revol, V., J. A. Innes, et al. Regulatory T cells are expanded in blood and disease sites in patients with tuberculosis. Am J Respir Crit Care Med, v.173, n.7, Apr 1, p.803-10. 2006.

Hawkins, W. G., J. Trcka, et al. The role of lipopolysaccharide in T-cell responses following DNA vaccination. Vaccine, v.21, n.13-14, Mar 28, p.1548-53. 2003.

Henderson, R. A., S. C. Watkins, et al. Activation of human dendritic cells following infection with Mycobacterium tuberculosis. J Immunol, v.159, n.2, Jul 15, p.635-43. 1997.

Hetzel, C., R. Janssen, et al. An epitope delivery system for use with recombinant mycobacteria. Infect Immun, v.66, n.8, Aug, p.3643-8. 1998.

Hickman, S. P., J. Chan, et al. Mycobacterium tuberculosis induces differential cytokine production from dendritic cells and macrophages with divergent effects on naive $\mathrm{T}$ cell polarization. J Immunol, v.168, n.9, May 1, p.4636-42. 2002.

Hoft, D. F. Tuberculosis vaccine development: goals, immunological design, and evaluation. Lancet, v.372, n.9633, Jul 12, p.164-75. 2008.

Hoft, D. F., R. M. Brown, et al. Bacille Calmette-Guerin vaccination enhances human gamma delta $\mathrm{T}$ cell responsiveness to mycobacteria suggestive of a memory-like phenotype. $\underline{\mathrm{J}}$

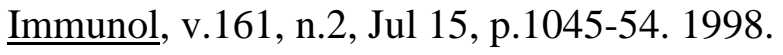

Horwitz, M. A. e G. Harth. A new vaccine against tuberculosis affords greater survival after challenge than the current vaccine in the guinea pig model of pulmonary tuberculosis. Infect Immun, v.71, n.4, Apr, p.1672-9. 2003. 
Hurchla, M. A., J. R. Sedy, et al. B and T lymphocyte attenuator exhibits structural and expression polymorphisms and is highly Induced in anergic CD4+ T cells. J Immunol, v.174, n.6, Mar 15, p.3377-85. 2005.

Jevsevar, S., V. Gaberc-Porekar, et al. Production of nonclassical inclusion bodies from which correctly folded protein can be extracted. Biotechnol Prog, v.21, n.2, Mar-Apr, p.632-9. 2005 .

Jimenez-Martinez, M. C., M. Linares, et al. Intracellular expression of interleukin-4 and interferon-gamma by a Mycobacterium tuberculosis antigen-stimulated CD4+ CD57+ T-cell subpopulation with memory phenotype in tuberculosis patients. Immunology, v.111, n.1, Jan, p.100-6. 2004.

Johnson, C. M., A. M. Cooper, et al. Mycobacterium tuberculosis aerogenic rechallenge infections in B cell-deficient mice. Tuber Lung Dis, v.78, n.5-6, p.257-61. 1997.

Kamath, A. T., C. G. Feng, et al. Differential protective efficacy of DNA vaccines expressing secreted proteins of Mycobacterium tuberculosis. Infect Immun, v.67, n.4, Apr, p.1702-7. 1999.

Kamath, A. T. E. A. In New Live Mycobacterial Vaccines: Defining Essential Steps Towards Clinical Development. WHO. Geneva, Switzerland, 2004. p.

Kang, P. B., A. K. Azad, et al. The human macrophage mannose receptor directs Mycobacterium tuberculosis lipoarabinomannan-mediated phagosome biogenesis. J Exp Med, v.202, n.7, Oct 3, p.987-99. 2005.

Keane, J., M. K. Balcewicz-Sablinska, et al. Infection by Mycobacterium tuberculosis promotes human alveolar macrophage apoptosis. Infect Immun, v.65, n.1, Jan, p.298-304. 1997.

Khader, S. A., G. K. Bell, et al. IL-23 and IL-17 in the establishment of protective pulmonary CD4+ T cell responses after vaccination and during Mycobacterium tuberculosis challenge. Nat Immunol, v.8, n.4, Apr, p.369-77. 2007.

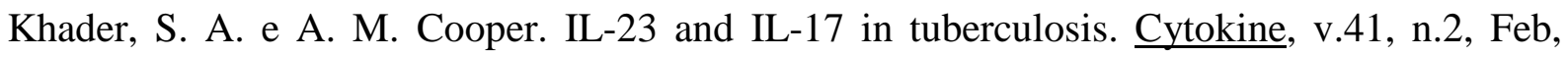
p.79-83. 2008.

Khader, S. A., J. E. Pearl, et al. IL-23 compensates for the absence of IL-12p70 and is essential for the IL-17 response during tuberculosis but is dispensable for protection and antigen-specific IFN-gamma responses if IL-12p70 is available. J Immunol, v.175, n.2, Jul 15, p.788-95. 2005.

Kindler, V., A. P. Sappino, et al. The inducing role of tumor necrosis factor in the development of bactericidal granulomas during BCG infection. Cell, v.56, n.5, Mar 10, p.73140. 1989.

Koch, R. Classics in infectious diseases. The etiology of tuberculosis: Robert Koch. Berlin, Germany 1882. Rev Infect Dis, v.4, n.6, Nov-Dec, p.1270-4. 1982. 
Kochi, A. The global tuberculosis situation and the new control strategy of the World Health Organization. 1991. Bull World Health Organ, v.79, n.1, p.71-5. 2001.

Krieg, A. M., L. Love-Homan, et al. CpG DNA induces sustained IL-12 expression in vivo and resistance to Listeria monocytogenes challenge. J Immunol, v.161, n.5, Sep 1, p.2428-34. 1998.

Kumar, V. e E. Sercarz. Genetic vaccination: the advantages of going naked. Nat Med, v.2, n.8, Aug, p.857-9. 1996.

Kumar, V., V. J. Bansal, et al. Hepatitis B virus envelope epitopes: gene assembly and expression in Escherichia coli of an immunologically reactive novel multiple-epitope polypeptide 1 (MEP-1). Gene, v.110, n.2, Jan 15, p.137-44. 1992.

Kursar, M., M. Koch, et al. Cutting Edge: Regulatory T cells prevent efficient clearance of Mycobacterium tuberculosis. J Immunol, v.178, n.5, Mar 1, p.2661-5. 2007.

Laemmli, U. K. Cleavage of structural proteins during the assembly of the head of bacteriophage T4. Nature, v.227, n.5259, Aug 15, p.680-5. 1970.

Langermans, J. A., T. M. Doherty, et al. Protection of macaques against Mycobacterium tuberculosis infection by a subunit vaccine based on a fusion protein of antigen $85 \mathrm{~B}$ and ESAT-6. Vaccine, v.23, n.21, Apr 15, p.2740-50. 2005.

Lasaro, M. O., A. M. Alves, et al. Antibody-inducing properties of a prototype bivalent herpes simplex virus/enterotoxigenic Escherichia coli DNA vaccine. FEMS Immunol Med Microbiol, v.35, n.1, Jan 21, p.25-31. 2003.

Lasaro, M. O., M. O. Diniz, et al. Anti-tumor DNA vaccines based on the expression of human papillomavirus-16 E6/E7 oncoproteins genetically fused with the glycoprotein D from herpes simplex virus-1. Microbes Infect, v.7, n.15, Dec, p.1541-50. 2005.

Lasaro, M. O., N. Tatsis, et al. Targeting of antigen to the herpesvirus entry mediator augments primary adaptive immune responses. Nat Med, v.14, n.2, Feb, p.205-12. 2008.

Lesley, J., R. Hyman, et al. CD44 and its interaction with extracellular matrix. Adv Immunol, v.54, p.271-335. 1993.

Li, B., M. D. Rossman, et al. Disease-specific changes in gammadelta T cell repertoire and function in patients with pulmonary tuberculosis. J Immunol, v.157, n.9, Nov 1, p.4222-9. 1996.

Lima, D. S. Avaliação da Vacina DNA-hsp65 na Indução de Auto-Agressão Tecidual. ( Dissertação de Mestrado). Imunologia Básica e Aplicada, FMRP-USP, Ribeirão Preto, 2006.

Lima, K. M., S. A. Santos, et al. Single dose of a vaccine based on DNA encoding mycobacterial hsp65 protein plus TDM-loaded PLGA microspheres protects mice against a virulent strain of Mycobacterium tuberculosis. Gene Ther, v.10, n.8, Apr, p.678-85. 2003. 
Lima, V. M., V. L. Bonato, et al. Role of trehalose dimycolate in recruitment of cells and modulation of production of cytokines and NO in tuberculosis. Infect Immun, v.69, n.9, Sep, p.5305-12. 2001.

Lindquist, S. e E. A. Craig. The heat-shock proteins. Annu Rev Genet, v.22, p.631-77. 1988.

Liu, M. A. DNA vaccines: a review. J Intern Med, v.253, n.4, Apr, p.402-10. 2003.

Lockhart, E., A. M. Green, et al. IL-17 production is dominated by gammadelta T cells rather than CD4 T cells during Mycobacterium tuberculosis infection. J Immunol, v.177, n.7, Oct 1, p.4662-9. 2006.

Locksley, R. M., N. Killeen, et al. The TNF and TNF receptor superfamilies: integrating mammalian biology. Cell, v.104, n.4, Feb 23, p.487-501. 2001.

Loundon, R. G., Roberts, R.M. . Droplet expulsion from the respiratory tract. American Review of Respiratory Disease, v.95, p.435-442. 1967.

Lowrie, D. B., C. L. Silva, et al. DNA vaccines against tuberculosis. Immunol Cell Biol, v.75, n.6, Dec, p.591-4. 1997.

1998.

Progress towards a new tuberculosis vaccine. BioDrugs, v.10, n.3, Sep, p.201-13.

Lowrie, D. B., R. E. Tascon, et al. Therapy of tuberculosis in mice by DNA vaccination. Nature, v.400, n.6741, Jul 15, p.269-71. 1999.

1994.

Towards a DNA vaccine against tuberculosis. Vaccine, v.12, n.16, Dec, p.1537-40.

Macatonia, S. E., N. A. Hosken, et al. Dendritic cells produce IL-12 and direct the development of Th1 cells from naive CD4+ T cells. J Immunol, v.154, n.10, May 15, p.50719. 1995.

Magdalini Moutafsi, E. A. A consensus epitope prediction approach identifies the breadth of murine T CD8+ cell responses to vaccinia virus. Nature Biotechnology, v.24, n.7, p.817-819. 2006.

Marsters, S. A., T. M. Ayres, et al. Herpesvirus entry mediator, a member of the tumor necrosis factor receptor (TNFR) family, interacts with members of the TNFR-associated factor family and activates the transcription factors NF-kappaB and AP-1. J Biol Chem, v.272, n.22, May 30, p.14029-32. 1997.

Masopust, D., S. J. Ha, et al. Stimulation history dictates memory CD8 T cell phenotype: implications for prime-boost vaccination. J Immunol, v.177, n.2, Jul 15, p.831-9. 2006.

Mcshane, H., A. A. Pathan, et al. Recombinant modified vaccinia virus Ankara expressing antigen 85A boosts BCG-primed and naturally acquired antimycobacterial immunity in humans. Nat Med, v.10, n.11, Nov, p.1240-4. 2004. 
Medici, M. A., M. T. Sciortino, et al. Protection by herpes simplex virus glycoprotein D against Fas-mediated apoptosis: role of nuclear factor kappaB. J Biol Chem, v.278, n.38, Sep 19, p.36059-67. 2003.

Michaluart, P., K. A. Abdallah, et al. Phase I trial of DNA-hsp65 immunotherapy for advanced squamous cell carcinoma of the head and neck. Cancer Gene Ther, v.15, n.10, Oct, p.676-84. 2008.

Moingeon, P., J. Haensler, et al. Towards the rational design of Th1 adjuvants. Vaccine, v.19, n.31, Aug 14, p.4363-72. 2001.

Mollenkopf, H. J., L. Grode, et al. Application of mycobacterial proteomics to vaccine design: improved protection by Mycobacterium bovis BCG prime-Rv3407 DNA boost vaccination against tuberculosis. Infect Immun, v.72, n.11, Nov, p.6471-9. 2004.

Montgomery, R. I., M. S. Warner, et al. Herpes simplex virus-1 entry into cells mediated by a novel member of the TNF/NGF receptor family. Cell, v.87, n.3, Nov 1, p.427-36. 1996.

Munk, M. E., A. J. Gatrill, et al. Target cell lysis and IL-2 secretion by gamma/delta T lymphocytes after activation with bacteria. J Immunol, v.145, n.8, Oct 15, p.2434-9. 1990.

Mustafa, A. S., K. E. Lundin, et al. Identification of promiscuous epitopes from the Mycobacterial 65-kilodalton heat shock protein recognized by human CD4(+) T cells of the Mycobacterium leprae memory repertoire. Infect Immun, v.67, n.11, Nov, p.5683-9. 1999.

North, R. J. Mice incapable of making IL-4 or IL-10 display normal resistance to infection with Mycobacterium tuberculosis. Clin Exp Immunol, v.113, n.1, Jul, p.55-8. 1998.

Oettinger, T., M. Jorgensen, et al. Development of the Mycobacterium bovis BCG vaccine: review of the historical and biochemical evidence for a genealogical tree. Tuber Lung Dis, v.79, n.4, p.243-50. 1999.

Olsen, A. W., P. R. Hansen, et al. Efficient protection against Mycobacterium tuberculosis by vaccination with a single subdominant epitope from the ESAT-6 antigen. Eur J Immunol, v.30, n.6, Jun, p.1724-32. 2000.

Ozaki, S. e J. A. Berzofsky. Antibody conjugates mimic specific B cell presentation of

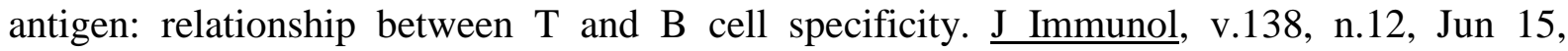
p.4133-42. 1987.

Patrick R. Murray, K. S. R., Michael A. Pfaller. Microbiologia Médica. Rio de Janeiro: Elsevier. 1997

Paula, M. O., Fonseca, D.M., Wowk, P.F., Silva, C.L., Bonato, V.L.D. Regulatory T cells might be a factor of susceptibility to experimental tuberculosis. 2007

Pearl, J. E., S. A. Khader, et al. IL-27 signaling compromises control of bacterial growth in mycobacteria-infected mice. J Immunol, v.173, n.12, Dec 15, p.7490-6. 2004. 
Plotkin, S. A. Vaccines: past, present and future. Nat Med, v.11, n.4 Suppl, Apr, p.S5-11. 2005.

Polisky, B., P. Greene, et al. Specificity of substrate recognition by the EcoRI restriction endonuclease. Proc Natl Acad Sci U S A, v.72, n.9, Sep, p.3310-4. 1975.

Pollara, G., M. Jones, et al. Herpes simplex virus type-1-induced activation of myeloid dendritic cells: the roles of virus cell interaction and paracrine type I IFN secretion. J Immunol, v.173, n.6, Sep 15, p.4108-19. 2004.

Quayle, A. J., K. B. Wilson, et al. Peptide recognition, T cell receptor usage and HLA restriction elements of human heat-shock protein (hsp) 60 and mycobacterial 65-kDa hspreactive $\mathrm{T}$ cell clones from rheumatoid synovial fluid. Eur J Immunol, v.22, n.5, May, p.131522. 1992.

Quesniaux, V., C. Fremond, et al. Toll-like receptor pathways in the immune responses to mycobacteria. Microbes Infect, v.6, n.10, Aug, p.946-59. 2004.

Radosevic, K. E. A. Presented at TB vaccines for the world. Vienna, Austria. April 19-21, 2006. p.

Rainer, T. H. L-selectin in health and disease. Resuscitation, v.52, n.2, Feb, p.127-41. 2002.

Raviglione, M. XDR-TB: entering the post-antibiotic era? Int J Tuberc Lung Dis, v.10, n.11, Nov, p.1185-7. 2006.

Raz, E., H. Tighe, et al. Preferential induction of a Th1 immune response and inhibition of specific IgE antibody formation by plasmid DNA immunization. Proc Natl Acad Sci U S A, v.93, n.10, May 14, p.5141-5. 1996.

Reed, M. B., P. Domenech, et al. A glycolipid of hypervirulent tuberculosis strains that inhibits the innate immune response. Nature, v.431, n.7004, Sep 2, p.84-7. 2004.

Roach, D. R., A. G. Bean, et al. TNF regulates chemokine induction essential for cell recruitment, granuloma formation, and clearance of mycobacterial infection. J Immunol, v.168, n.9, May 1, p.4620-7. 2002.

Rook, G. A. Th2 cytokines in susceptibility to tuberculosis. Curr Mol Med, v.7, n.3, May, p.327-37. 2007.

Rook, G. A., K. Dheda, et al. Immune responses to tuberculosis in developing countries: implications for new vaccines. Nat Rev Immunol, v.5, n.8, Aug, p.661-7. 2005.

Rooney, I. A., K. D. Butrovich, et al. The lymphotoxin-beta receptor is necessary and sufficient for LIGHT-mediated apoptosis of tumor cells. J Biol Chem, v.275, n.19, May 12, p.14307-15. 2000.

Rosada, R. S., L. G. De La Torre, et al. Protection against tuberculosis by a single intranasal administration of DNA-hsp65 vaccine complexed with cationic liposomes. BMC Immunol, v.9, p.38. 2008. 
Salgame, P. Host innate and Th1 responses and the bacterial factors that control Mycobacterium tuberculosis infection. Curr Opin Immunol, v.17, n.4, Aug, p.374-80. 2005.

Sallusto, F., J. Geginat, et al. Central memory and effector memory T cell subsets: function, generation, and maintenance. Annu Rev Immunol, v.22, p.745-63. 2004.

Sambrook, J., Fritsch, E.F., Maniatis, T. . Molecular Cloning: a laboratory manual. Cold Spring Harbor, N.Y: Cold Spring Harbor Laboratory Press. 1989

Santos-Junior, R. R., A. Sartori, et al. Immunomodulation and protection induced by DNAhsp65 vaccination in an animal model of arthritis. Hum Gene Ther, v.16, n.11, Nov, p.133845. 2005.

Santos Junior, R. R., A. Sartori, et al. Immune modulation induced by tuberculosis DNA vaccine protects non-obese diabetic mice from diabetes progression. Clin Exp Immunol, v.149, n.3, Sep, p.570-8. 2007.

Saunders, B. M., A. A. Frank, et al. CD4 is required for the development of a protective granulomatous response to pulmonary tuberculosis. Cell Immunol, v.216, n.1-2, Mar-Apr, p.65-72. 2002.

Schlesinger, L. S. Macrophage phagocytosis of virulent but not attenuated strains of Mycobacterium tuberculosis is mediated by mannose receptors in addition to complement receptors. J Immunol, v.150, n.7, Apr 1, p.2920-30. 1993.

Seah, G. T. e G. A. Rook. High levels of mRNA encoding IL-4 in unstimulated peripheral blood mononuclear cells from tuberculosis patients revealed by quantitative nested reverse transcriptase-polymerase chain reaction; correlations with serum IgE levels. Scand J Infect Dis, v.33, n.2, p.106-9. 2001.

Sedy, J. R., M. Gavrieli, et al. B and T lymphocyte attenuator regulates T cell activation through interaction with herpesvirus entry mediator. Nat Immunol, v.6, n.1, Jan, p.90-8. 2005.

Serbina, N. V. e J. L. Flynn. Early emergence of CD8(+) T cells primed for production of type 1 cytokines in the lungs of Mycobacterium tuberculosis-infected mice. Infect Immun, v.67, n.8, Aug, p.3980-8. 1999.

CD8(+) $\mathrm{T}$ cells participate in the memory immune response to Mycobacterium tuberculosis. Infect Immun, v.69, n.7, Jul, p.4320-8. 2001.

Silva, C. L., V. L. Bonato, et al. Immunotherapy with plasmid DNA encoding mycobacterial hsp65 in association with chemotherapy is a more rapid and efficient form of treatment for tuberculosis in mice. Gene Ther, v.12, n.3, Feb, p.281-7. 2005.

2001.

Cytotoxic T cells and mycobacteria. FEMS Microbiol Lett, v.197, n.1, Apr 1, p.11-8.

Skeiky, Y. A., M. R. Alderson, et al. Differential immune responses and protective efficacy induced by components of a tuberculosis polyprotein vaccine, $M$. tuberculosis $72 \mathrm{~F}$, delivered as naked DNA or recombinant protein. J Immunol, v.172, n.12, Jun 15, p.7618-28. 2004. 
Skeiky, Y. A., M. J. Lodes, et al. Cloning, expression, and immunological evaluation of two putative secreted serine protease antigens of Mycobacterium tuberculosis. Infect Immun, v.67, n.8, Aug, p.3998-4007. 1999.

Skeiky, Y. A. e J. C. Sadoff. Advances in tuberculosis vaccine strategies. Nat Rev Microbiol, v.4, n.6, Jun, p.469-76. 2006.

Smith, P. A. M., Ar. In Tuberculosis: Pathogenesis, Protection and Control American Society for Microbiology, Washington DC. 1994. 47-59 p.

Souza, P. R., C. R. Zarate-Blades, et al. Protective efficacy of different strategies employing Mycobacterium leprae heat-shock protein 65 against tuberculosis. Expert Opin Biol Ther, v.8, n.9, Sep, p.1255-64. 2008.

Stenger, S. Cytolytic T cells in the immune response to mycobacterium tuberculosis. $\underline{\text { Scand J }}$ Infect Dis, v.33, n.7, p.483-7. 2001.

Swain, S. L., A. D. Weinberg, et al. IL-4 directs the development of Th2-like helper effectors. J Immunol, v.145, n.11, Dec 1, p.3796-806. 1990.

Tailleux, L., N. Pham-Thi, et al. DC-SIGN induction in alveolar macrophages defines privileged target host cells for mycobacteria in patients with tuberculosis. PLoS Med, v.2, n.12, Dec, p.e381. 2005.

Tailleux, L., O. Schwartz, et al. DC-SIGN is the major Mycobacterium tuberculosis receptor on human dendritic cells. J Exp Med, v.197, n.1, Jan 6, p.121-7. 2003.

Talbot, E. A., M. D. Perkins, et al. Disseminated bacille Calmette-Guerin disease after vaccination: case report and review. Clin Infect Dis, v.24, n.6, Jun, p.1139-46. 1997.

Tamada, K., K. Shimozaki, et al. Modulation of T-cell-mediated immunity in tumor and graft-versus-host disease models through the LIGHT co-stimulatory pathway. Nat Med, v.6, n.3, Mar, p.283-9. 2000.

Tanghe, A., P. Lefevre, et al. Immunogenicity and protective efficacy of tuberculosis DNA vaccines encoding putative phosphate transport receptors. J Immunol, v.162, n.2, Jan 15, p.1113-9. 1999.

Thoma-Uszynski, S., S. Stenger, et al. Induction of direct antimicrobial activity through mammalian toll-like receptors. Science, v.291, n.5508, Feb 23, p.1544-7. 2001.

Thurnher, M., R. Ramoner, et al. Bacillus Calmette-Guerin mycobacteria stimulate human blood dendritic cells. Int J Cancer, v.70, n.1, Jan 6, p.128-34. 1997.

Tonheim, T. C., J. Bogwald, et al. What happens to the DNA vaccine in fish? A review of current knowledge. Fish Shellfish Immunol, v.25, n.1-2, Jul, p.1-18. 2008.

Tuberculosis. Nature Medicine. 13: 263-277 p. 2007. 
Tuomela, M., I. Stanescu, et al. Validation overview of bio-analytical methods. Gene Ther, v.12 Suppl 1, Oct, p.S131-8. 2005.

Turner, J., M. Gonzalez-Juarrero, et al. In vivo IL-10 production reactivates chronic pulmonary tuberculosis in C57BL/6 mice. J Immunol, v.169, n.11, Dec 1, p.6343-51. 2002.

Ulmer, J. B., M. A. Liu, et al. Expression and immunogenicity of Mycobacterium tuberculosis antigen 85 by DNA vaccination. Vaccine, v.15, n.8, Jun, p.792-4. 1997.

Underhill, D. M., A. Ozinsky, et al. Toll-like receptor-2 mediates mycobacteria-induced proinflammatory signaling in macrophages. Proc Natl Acad Sci U S A, v.96, n.25, Dec 7, p.14459-63. 1999.

Van Eden, W., R. Van Der Zee, et al. Heat-shock proteins induce T-cell regulation of chronic inflammation. Nat Rev Immunol, v.5, n.4, Apr, p.318-30. 2005.

Van Pinxteren, L. A., J. P. Cassidy, et al. Control of latent Mycobacterium tuberculosis infection is dependent on CD8 T cells. Eur J Immunol, v.30, n.12, Dec, p.3689-98. 2000.

Vankayalapati, R., A. Garg, et al. Role of NK cell-activating receptors and their ligands in the lysis of mononuclear phagocytes infected with an intracellular bacterium. J Immunol, v.175, n.7, Oct 1, p.4611-7. 2005.

Velders, M. P., S. Weijzen, et al. Defined flanking spacers and enhanced proteolysis is essential for eradication of established tumors by an epitope string DNA vaccine. $\mathrm{J}$ Immunol, v.166, n.9, May 1, p.5366-73. 2001.

Villarino, A., L. Hibbert, et al. The IL-27R (WSX-1) is required to suppress T cell hyperactivity during infection. Immunity, v.19, n.5, Nov, p.645-55. 2003.

Villarino, A. V., E. Huang, et al. Understanding the pro- and anti-inflammatory properties of IL-27. J Immunol, v.173, n.2, Jul 15, p.715-20. 2004.

Vordermeier, H. M., N. Venkataprasad, et al. Increase of tuberculous infection in the organs of B cell-deficient mice. Clin Exp Immunol, v.106, n.2, Nov, p.312-6. 1996.

Wang, Q. M., S. H. Sun, et al. Epitope DNA vaccines against tuberculosis: spacers and ubiquitin modulates cellular immune responses elicited by epitope DNA vaccine. Scand J Immunol, v.60, n.3, Sep, p.219-25. 2004.

Watanabe, N., M. Gavrieli, et al. BTLA is a lymphocyte inhibitory receptor with similarities to CTLA-4 and PD-1. Nat Immunol, v.4, n.7, Jul, p.670-9. 2003.

Watson, R. J., J. H. Weis, et al. Herpes simplex virus type-1 glycoprotein D gene: nucleotide sequence and expression in Escherichia coli. Science, v.218, n.4570, Oct 22, p.381-4. 1982.

Weinrich Olsen, A., L. A. Van Pinxteren, et al. Protection of mice with a tuberculosis subunit vaccine based on a fusion protein of antigen $85 \mathrm{~b}$ and esat- 6 . Infect Immun, v.69, n.5, May, p.2773-8. 2001. 
Winau, F., S. Weber, et al. Apoptotic vesicles crossprime CD8 T cells and protect against tuberculosis. Immunity, v.24, n.1, Jan, p.105-17. 2006.

Winegar, R. A., J. A. Monforte, et al. Determination of tissue distribution of an intramuscular plasmid vaccine using PCR and in situ DNA hybridization. Hum Gene Ther, v.7, n.17, Nov 10, p.2185-94. 1996.

Wolff, J. A., J. J. Ludtke, et al. Long-term persistence of plasmid DNA and foreign gene expression in mouse muscle. Hum Mol Genet, v.1, n.6, Sep, p.363-9. 1992.

Wolff, J. A., R. W. Malone, et al. Direct gene transfer into mouse muscle in vivo. Science, v.247, n.4949 Pt 1, Mar 23, p.1465-8. 1990.

Woodbury, C. P., Jr., O. Hagenbuchle, et al. DNA site recognition and reduced specificity of the Eco RI endonuclease. J Biol Chem, v.255, n.23, Dec 10, p.11534-48. 1980.

Wright, S. D. e S. C. Silverstein. Receptors for C3b and C3bi promote phagocytosis but not the release of toxic oxygen from human phagocytes. J Exp Med, v.158, n.6, Dec 1, p.2016-23. 1983.

Yewdell, J. W. e J. R. Bennink. Immunodominance in major histocompatibility complex class I-restricted T lymphocyte responses. Annu Rev Immunol, v.17, p.51-88. 1999.

Zhu, X., N. Venkataprasad, et al. Functions and specificity of T cells following nucleic acid vaccination of mice against Mycobacterium tuberculosis infection. $\mathrm{J}$ Immunol, v.158, n.12, Jun 15, p.5921-6. 1997.

Zugel, U. e S. H. Kaufmann. Immune response against heat shock proteins in infectious diseases. Immunobiology, v.201, n.1, Sep, p.22-35. 1999. 


\section{ANEXO}

Anexo 1: Protocolo do gel de poliacrilamida utilizado nesse trabalho

\begin{tabular}{|l|l|}
\hline \multicolumn{1}{|c|}{ Gel de Resolução } & $13,5 \%$ \\
\cline { 2 - 2 } & Volume para 2 géis \\
\hline Bis Acrilamida $(0,8 \%: 30)$ & $5,63 \mathrm{~mL}$ \\
\hline Água mili-Q & $97,5 \mu \mathrm{L}$ \\
\hline Tampão do gel $(3 \mathrm{M})^{*}$ & $3,53 \mathrm{~mL}$ \\
\hline Glicerol (pesar) & $1,43 \mathrm{~g}$ \\
\hline TEMED & $9 \mu \mathrm{L}$ \\
\hline Persulfato de Amônio $(10 \%)$ & $90 \mu \mathrm{L}$ \\
\hline Total & $\sim 12,5 \mathrm{~mL}$ \\
\hline
\end{tabular}

\begin{tabular}{|l|l|}
\hline \multicolumn{1}{|c|}{ Gel de Empilhamento } & Volume para 2 géis \\
\hline Bis Acrilamida $(0,8 \%: 30)$ & $0,53 \mathrm{~mL}$ \\
\hline Água mili-Q & $2,48 \mathrm{~mL}$ \\
\hline Tampão do gel $(3 \mathrm{M})^{*}$ & $0,99 \mathrm{~mL}$ \\
\hline TEMED & $4,8 \mu \mathrm{L}$ \\
\hline Persulfato de Amônio $(10 \%)$ & $48 \mu \mathrm{L}$ \\
\hline Total & $\sim 4,5 \mathrm{~mL}$ \\
\hline
\end{tabular}

*Tampão do gel (3M):

Tris $3 \mathrm{M}=36,34 \mathrm{~g}$

SDS $0,3 \%=0,3 \mathrm{~g}$

Água milli-Q q.s.p. $=100 \mathrm{~mL}$

$\mathrm{pH} 8,45$

Tampão da Cuba:

Tris $0,1 \mathrm{M}=6,055 \mathrm{~g}$

Tricina $0,1 \mathrm{M}=8,96 \mathrm{~g}$

SDS $0,1 \%=0,5 \mathrm{~g}$

Água mili-Q q.s.p. $=500 \mathrm{~mL}$

$\mathrm{pH} 8,25$

Iniciar a corrida à $30 \mathrm{~V}$ constante até a amostra entrar no gel de resolução ( 1h) depois mudar para $100 \mathrm{~V}$ constante. 
Anexo 2: Gel de agarose da caracterização do vetor pVAX e da vacina pVAXhsp65 também utilizados nesse projeto. A produção e caracterização dessas construções vacinais são realizadas da mesma forma que as outras vacinas exceto pela clivagem realizada com a enzima BamHI (Invitrogen) ao invés da enzima HindIII. L-marcador de $1 \mathrm{~Kb}$ (Invitrogen), 1pVAX fechado, 2-pVAX clivado com a enzima BamHI, 3-pVAXhsp65 fechado, 4pVAXhsp65 clivado com a enzima BamHI. Ambos os plasmideos apenas linearizam com a clivagem, pelo tamanho podemos caracterizar o pVAX de 3000pb e o pVAXhsp65 de 6000pb (3000pb do vetor $+3000 \mathrm{pb}$ do inserto hsp65).

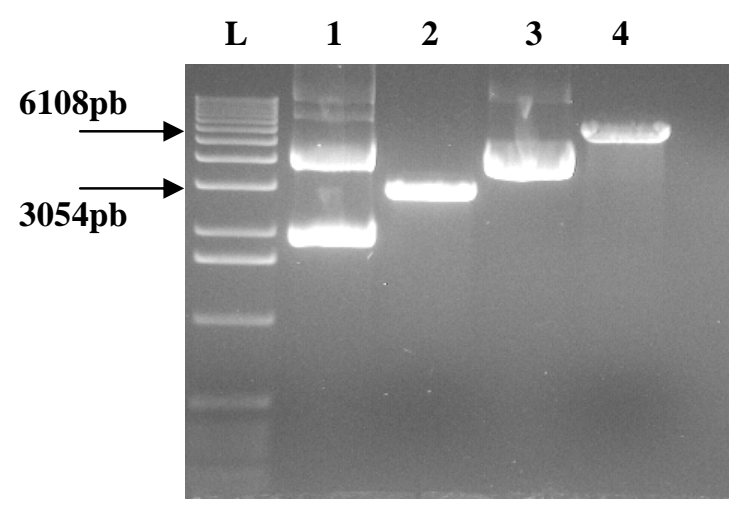

Anexo 3: "Western blot" utilizado-se o anticorpo anti-Vac1 para confirmar a expressão da proteína Hsp65 codificada pela vacina pVAXhsp65. L-marcador - proteínas com massas moleculares conhecidas foram usadas como marcadores da migração (Fermentas), 1-células HEK transfectadas com pVAXhsp65, 2-células HEK transfectadas com pVAX. M-meio Psedimento celular, S-sobrenadante celular. O Western revelou a banda da proteína Hsp65 $(56,89 \mathrm{kDa})$ no sedimento e sobrenadante celulares.

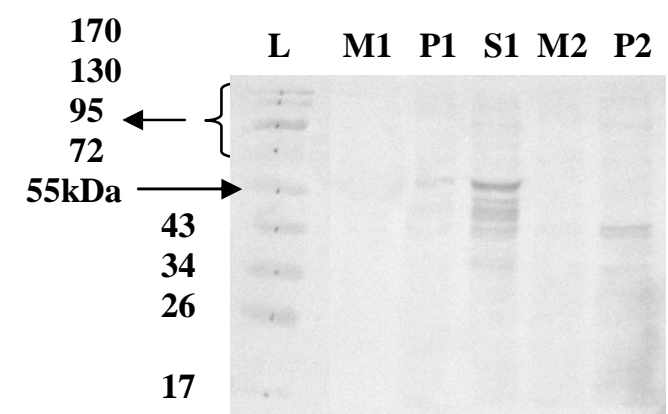


Anexo 4: Análise eletroforética da Hsp65 expressa e purificada. A proteína Hsp65 foi expressa a $30^{\circ} \mathrm{C}$ por 16 horas a partir da adição de $0,3 \mathrm{mM}$ de IPTG e purificada em condições desnaturantes por cromatografia de afinidade no aparelho Äkta Purifier com a coluna HiTrap Chelating HP5mL. L-marcador (Invitrogen), 1-cultura antes da adição do IPTG, 2- após indução com IPTG, 3-sobrenadante após lise celular, 4-Hsp65 purificada (64,15kDa).

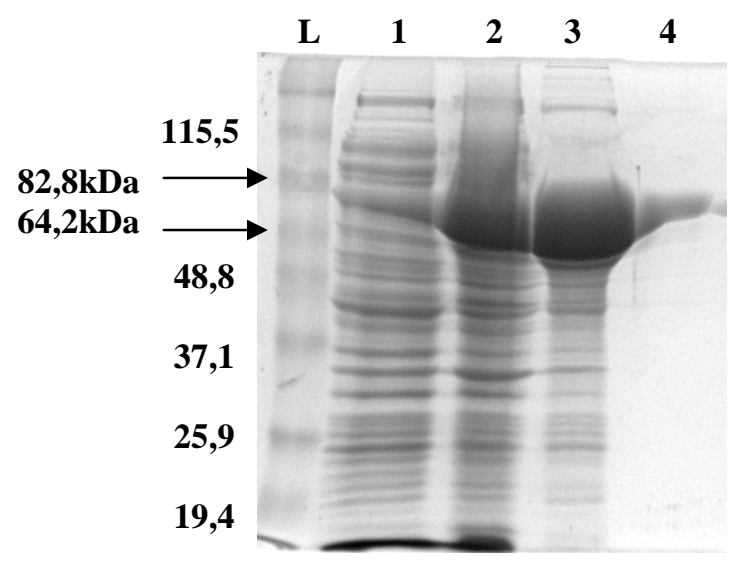


Verso da página 138
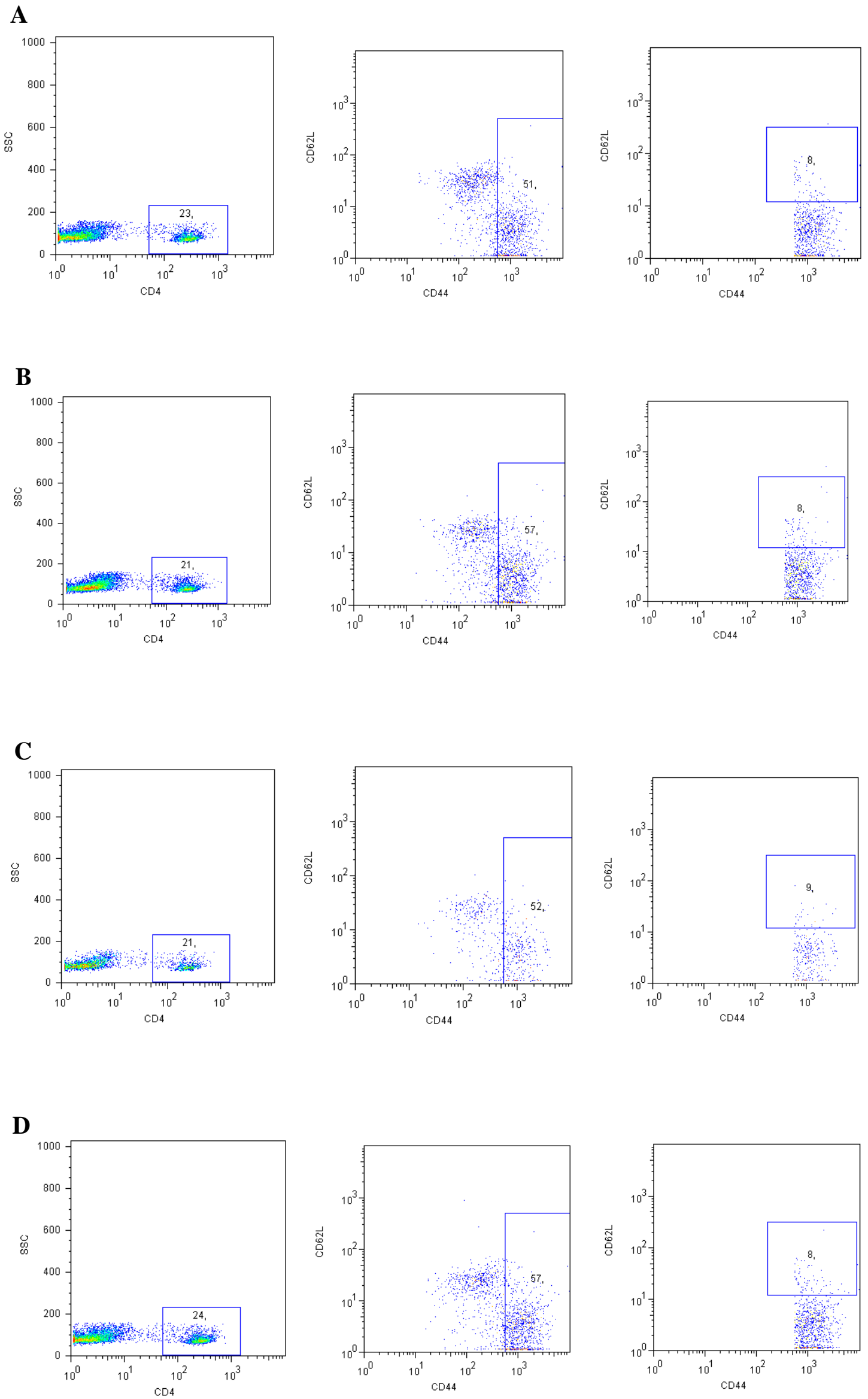
Verso da página 139

A
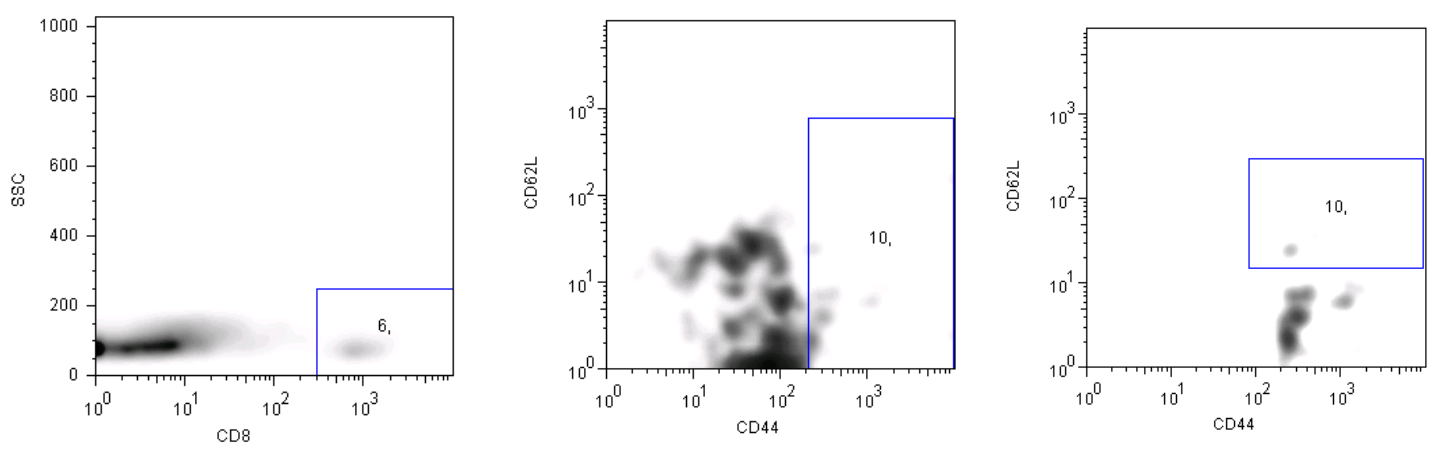

\section{B}
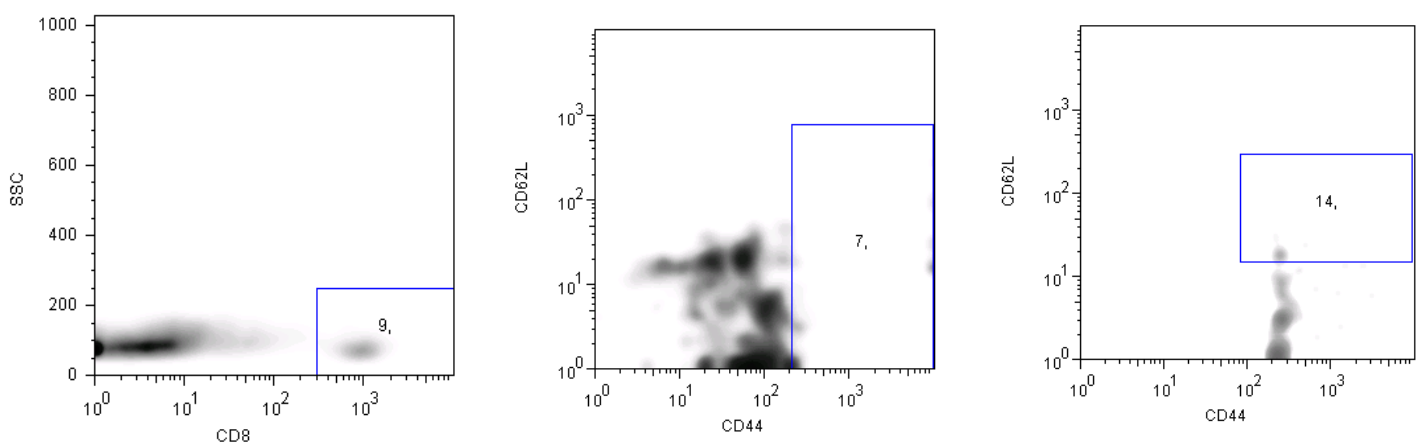

C
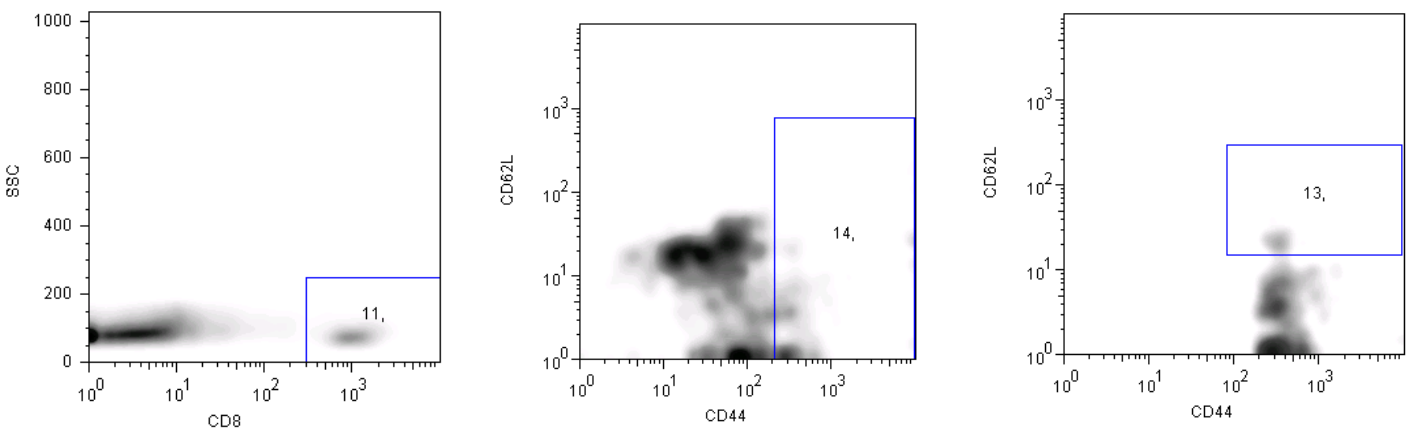

D
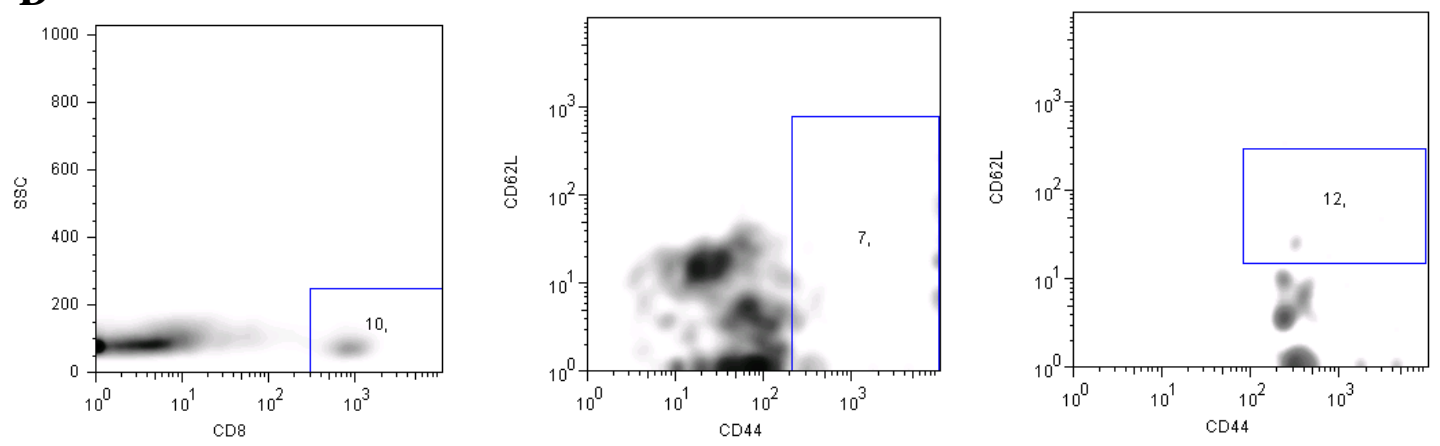